\title{
RESOURCE
}

AND 2. AE the

LND 4 (5)

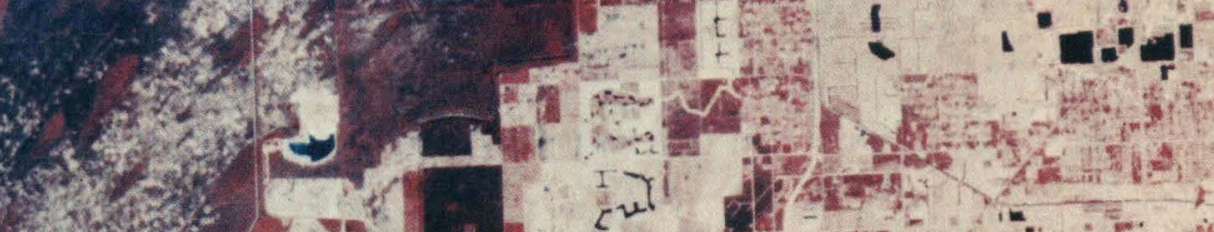
$\sin ^{2} x$

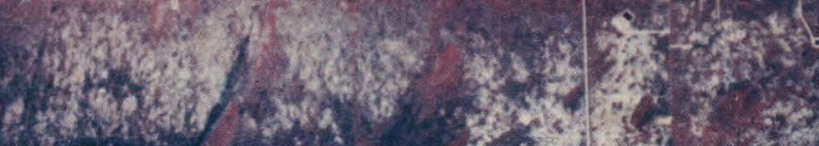

\%)

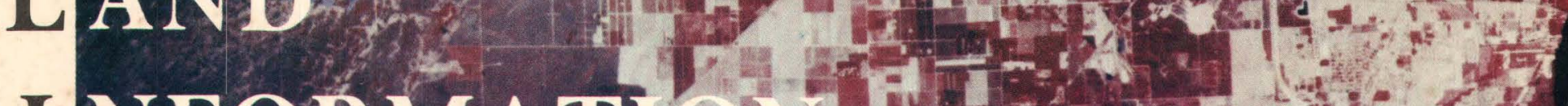

I NFORMAT OAY, EY ?

SOUTH DADE COUNTY, FLORIDA

UNITED STATES DEPARTMENT OF THE INTERIOR
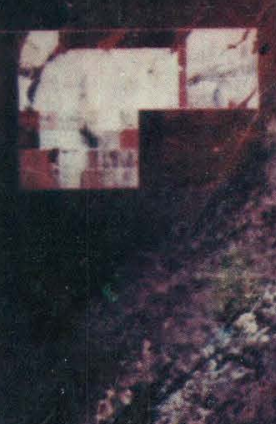

2

6.

s.t.

$-2,020$

2द?

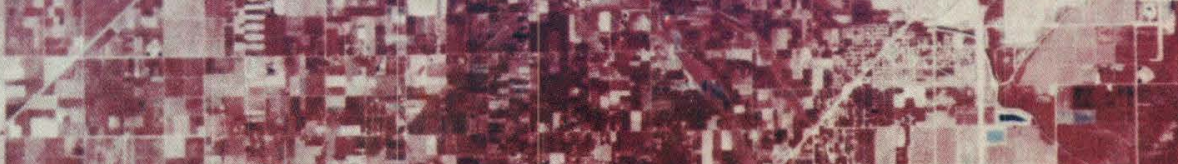

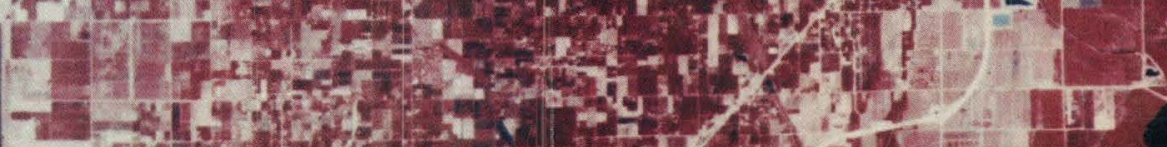

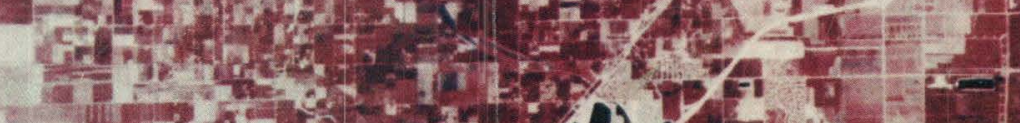

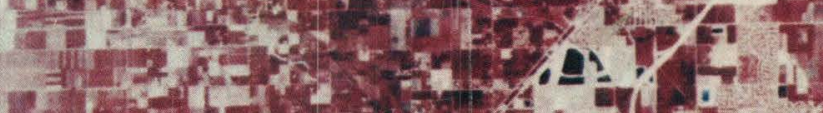
$\int$ E

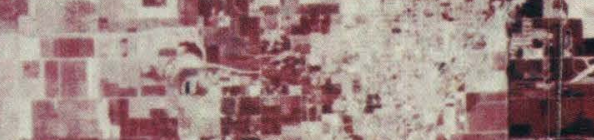

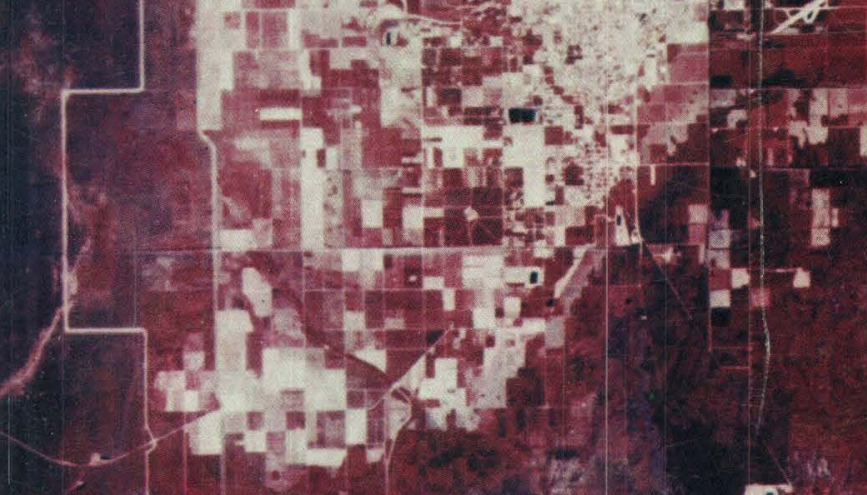

$7, \frac{1}{12}$

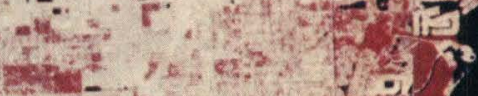




\section{RESOURCE AND LAND INFORMATION FOR SOUTH DADE COUNTY, FLORIDA}

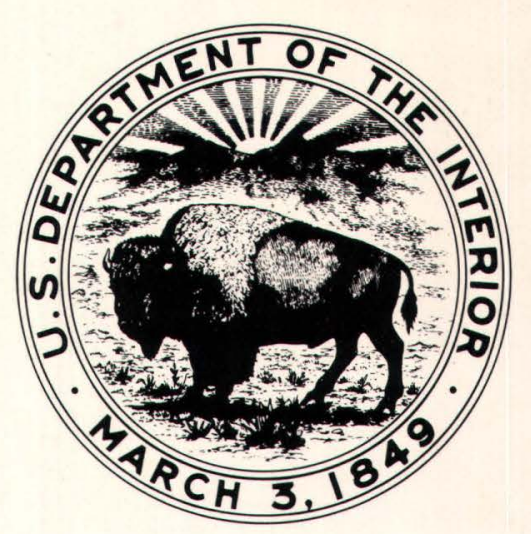

\section{U.S. Department of the Interior}

GEOLOGICAL SURVEY INVESTIGATION I-850

\section{Contributions from:}

Geological Survey

Bureau of Mines

Bureau of Outdoor Recreation

National Park Service

Bureau of Sport Fisheries and Wildlife

Bureau of Indian Affairs

Resource Management Office, Miccosukee Tribe

University of Miami, School of Medicine, Laboratory of Virology

Dade County Pollution Control Department 


\title{
UNITED STATES DEPARTMENT OF THE INTERIOR ROGERS C.B.MORTON, Secretary
}

\author{
Library of Congress Catalog Card No. 73-600216
}




\section{FOREWORD}

A major function of the Interior Department since its inception, more than a century ago, has been to collect and disseminate information about the nation's natural resources. Initially, this information was collected primarily to increase understanding of earth resources and support their development. During the last 60 years the Department has placed more and more emphasis on conservation of both our finite resources and the environment of which they are integral parts. Further, as the population has shifted from farm to city, Departmental interests have moved increasingly toward urban concerns.

These changes to meet changing needs have generally been accomplished piecemeal, problem by problem and agency by agency. But ad hoc methods no longer suffice to deal with the complicated interactions among a large and growing population, an expanding economy, dwindling resources, and an ecosystem of limited tolerance. If the Department is to do its part in aiding environmentally responsible development it must organize its information programs more systematically. To some degree this has already been done. Analysis of such difficult matters as bringing Alaskan oil to market, developing electric power from southwestern coal, and providing adequate airport facilities for metropolitan Florida have involved coordinated participation by many elements in the Department. The requirements of such legislation as the National Environmental Policy Act and the proposed Land Use Policy and Planning Assistance Act pin-point the need for a better national resource and land information system.

Developing an effective environmental information system is no small task, and we are proceeding with care and caution. This folio on south Dade County, Florida, is part of that effort; one of a series of exercises designed to show specifically the need for comprehensive resource and land information in reaching sound solutions to environmental problems, the Department's potential for contributing much of the needed information, and the ways in which the information may be used by planners and decision makers to define and weigh alternative solutions.

The report, an interim one on work in progress is illustrative rather than definitive. Ȧs its authors point out, its limitations are manifest; for example, the consideration of alternatives is far from exhaustive and wholly lacks comparative cost analysis. Nevertheless, it is hoped that the report will serve the immediate needs of Dade County planners and managers to some degree, and at the same time suggest to a wider audience the value of a national resource and land information system.

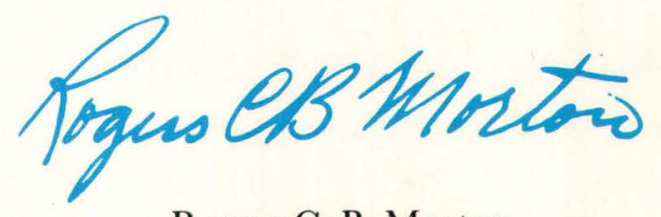

Rogers C. B. Morton

Secretary of the Interior 


\section{CONTENTS}

\section{Page}

INTRODUCTION

PHYSICAL SETTING

Geological Survey-Z. S. Altschuler, K. E. Vanlier, J. T. Armbruster, and C.S. Zen

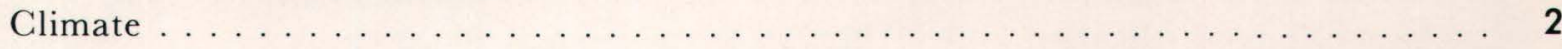

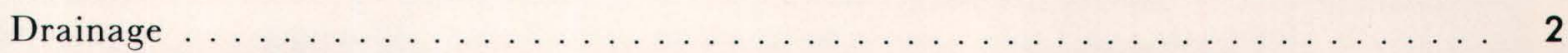

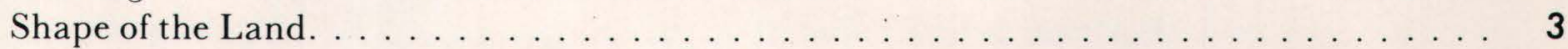

Soils ............................. 5

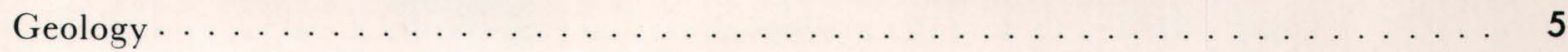

$\begin{array}{ll}\text { URBANIZATION } & \mathbf{8}\end{array}$

Geological Survey-J. T. Armbruster, K. E. Vanlier, K. A. Fitzpatrick, and J. R. Anderson

Trends in Urban Growth. . . . . . . . . . . . . . . . . . . . . . . . . . 8

Land Use . . . . . . . . . . . . . . . . . . . . . . . . . 10

$\begin{array}{lr}\text { NATURAL HAZARDS } & 14\end{array}$

Geological Survey-K. E. Vanlier, J. T. Armbruster,

Z. S. Altschuler, and H. C. Mattraw

Flooding from Storm Runoff . . . . . . . . . . . . . . . . . . . . . 14

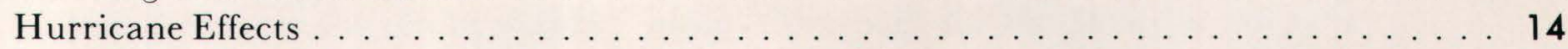

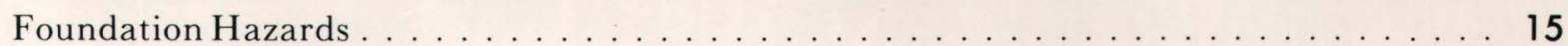

$\begin{array}{ll}\text { MINERAL RESOURCES } & 16\end{array}$

Bureau of Mines-C. D. Edgerton

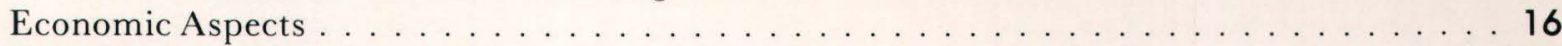

Quarrying Methods . . . . . . . . . . . . . . . . . . . . . . . 16

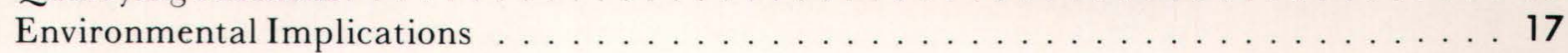

MANAGING THE WATER SYSTEM 18

Geological Survey-Howard Klein

Water-Related Problems. . . . . . . . . . . . . . . . . . . . . . 19

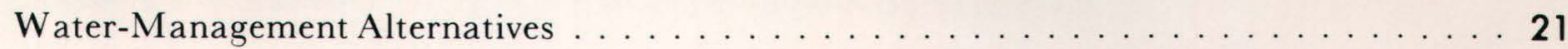

$\begin{array}{lr}\text { ENVIRONMENTAL QUALITY } & 26\end{array}$

Geological Survey-B. F. McPherson, H. C. Mattraw, H. J. Freiberger, Z. S. Altschuler, and C. S. Zen

Univ. of Miami, School of Medicine, Laboratory of Virology-M. M. Sigel

Dade County Pollution Control Dept.-H. J. Schmitz

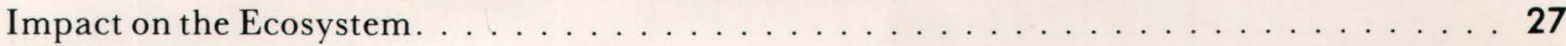

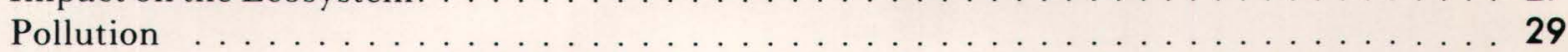

Waste Management. . . . . . . . . . . . . . . . . . . . . . . . . 34

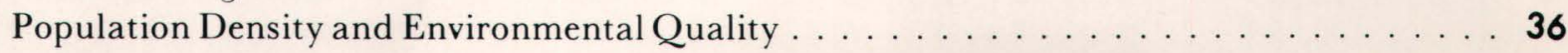


Existing and Proposed Parks . . . . . . . . . . . . . . . . . . . . . . . . . 39

Waterfront Recreation Development . . . . . . . . . . . . . . . . . . . . . 40

$\begin{array}{lr}\text { EVERGLADES NATIONAL PARK } & 43\end{array}$

National Park Service-G. Y. Hendrix, and P. L. Zobel

Wildlife Resources. . . . . . . . . . . . . . . . . . . . . 44

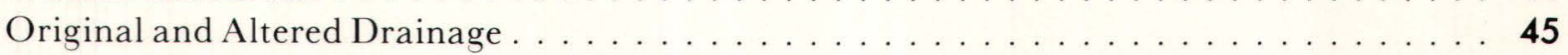

Wildfires and Prescribed Burning . . . . . . . . . . . . . . . . . . . 46

Park Concerns Outside Its Boundaries . . . . . . . . . . . . . . . . . . 47

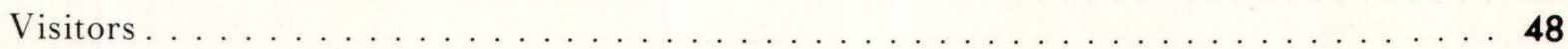

$\begin{array}{lr}\text { COASTAL ZONE } & 49\end{array}$

National Park Service-G. Y. Hendrix, and P. L. Zobel

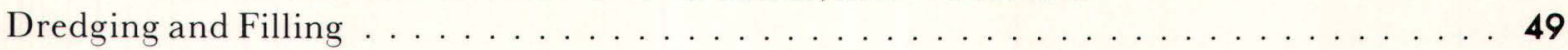

Canals and Waste Disposal . . . . . . . . . . . . . . . . . . . 50

Electric Power . . . . . . . . . . . . . . . . . . . . . . . . . 51

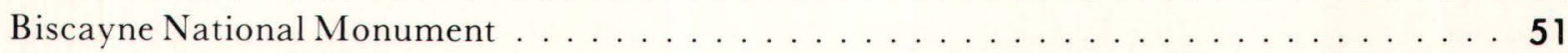

FISH AND WILDLIFE $\quad 54$

Bureau of Sports Fisheries and Wildlife-R. T. Webb and D. W. Pfitzer

The Estuaries . . . . . . . . . . . . . . . . . . . . . . . 54

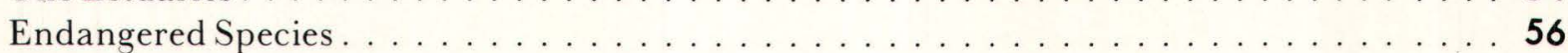

Fish and Wildlife Oriented Outdoor Recreation . . . . . . . . . . . . . . . . 57

Exotic Animals and Plants. . . . . . . . . . . . . . . . . . . . . . . . . . . . . . 59

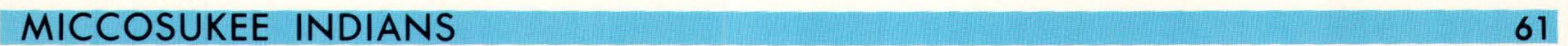

Bureau of Indian Affairs-D. E. Williams

Resource Management Office, Miccosukee Tribe-John Adams

Internal Problems . . . . . . . . . . . . . . . . . . . . . . . . 62

External Problems . . . . . . . . . . . . . . 62 



\section{INTRODUCTION}

South Dade County, at the southeast corner of Florida, exemplifies many of the environmental concerns that have developed throughout the United States. Considerable environmental information has recently been assembled from this region, and some of it is presented in this experimental report in folio form. We are aware that south Dade County does not constitute a viable planning unit-it is only a fraction of the south Florida environmental system that includes not only Metropolitan Miami but extends throughout the Everglades. But we are not prepared to report on the larger planning unit at this time.

South Dade County's spectacularly rapid urban growth during the last decade has been generated by its pleasant subtropical climate, its outstanding recreational opportunities, and the presence of a remarkably attractive hinterland, the Everglades. These attractions and its favorable geographic situation have also spurred development of the area as a center of international marketing and commercial activities.

Builders and businessmen, tourists, and residents compete for land and water. Today, the resources that have provided habitat for a unique assemblage of plants and animals and have drawn so many people are diminishing in amount and in quality. The central problem is how to accommodate growth and maintain environmental quality at the same time.

Solving this problem is extraordinarily difficult because of the intricate interdependence of all parts of the environmental system. Thus, clearing, dredging, and building affect air, water, land, plants, animals, and man. Management decisions involving the environment are likely to be successful only if based on complete information and thorough understanding of the probable consequences-social, physical, economic, biologic, and aesthetic-of a given course of action.

This report does not offer all the information or interpretation needed as a comprehensive basis for regional decision making. It does, however, provide a sampling of the information required to develop alternative solutions for some representative problems, and weighs the pros and cons of some selected alternatives.

Led by the Geological Survey under the direction of Thomas J. Buchanan, six Interior Department Bureaus and several other organizations, cited on the title page, have contributed to this report. Other groups that have made invaluable additions include the Metropolitan Dade County Planning Department, the Miami-Dade Water and Sewer Authority, the Center for Urban Studies of the University of Miami, and the Florida Department of Transportation.

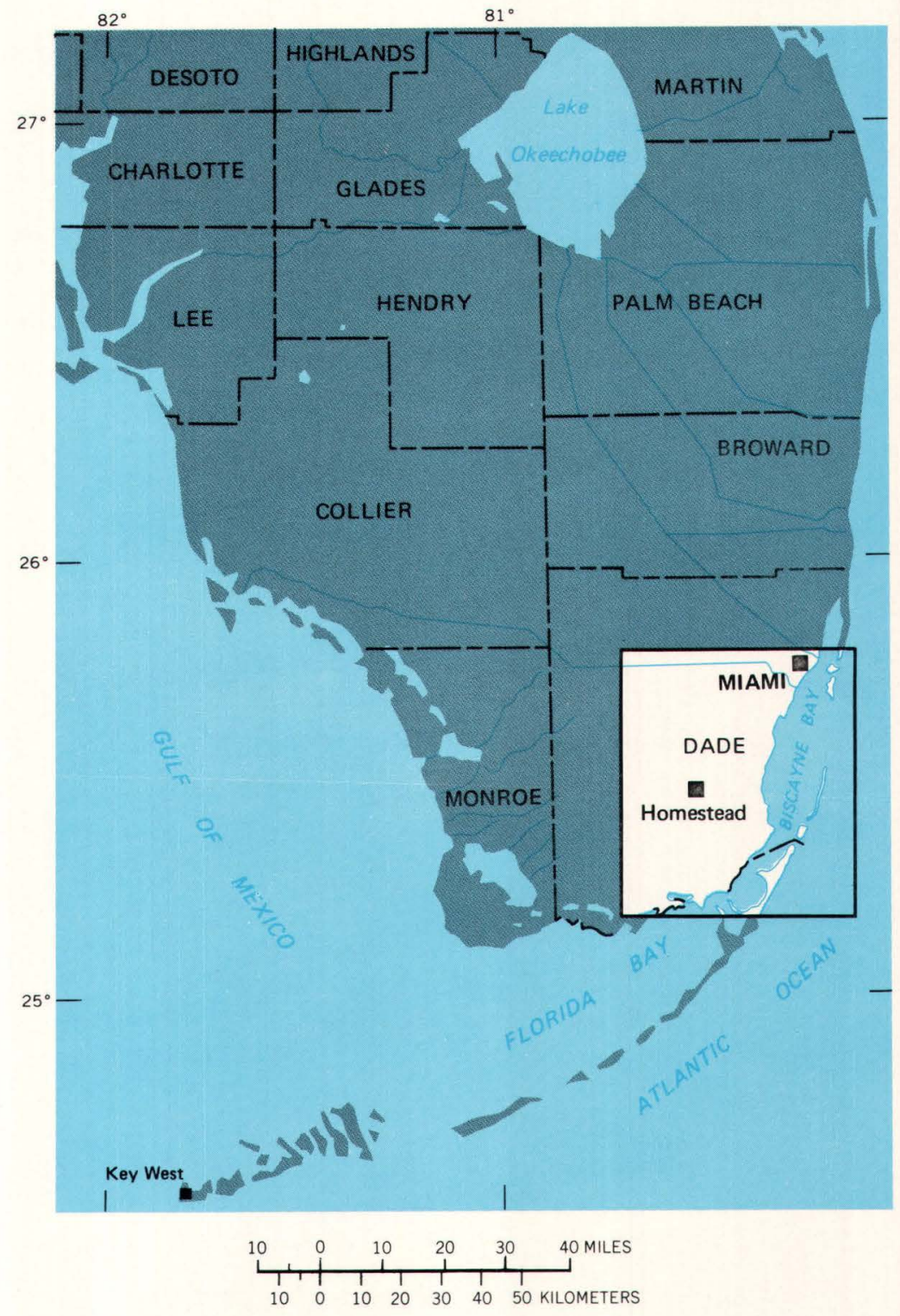

The area covered by this report includes about 1800 square miles in the southern part of Dade County, Florida. 


\section{PHYSICAL SETTING}

In south Dade County, as elsewhere, the climate and the geology determine the shape of the land, the drainage characteristics, and ultimately the activities of plants and animals and of man.

\section{Climate}

South Dade County has a subtropical, marine climate with long, warm, rainy summers and mild dry winters. Extremes in temperature are moderated by the ocean which warms the air in winter and cools it in summer. Humidity generally is high, usually decreasing during the day as the temperature rises.

Nearly constant southeast breezes, blowing across the warm Gulf Stream, tend to prevent northern cold fronts from reaching Miami. Occasionally, however, cold fronts invade the area and frosts occur. Average annual rainfall is around 60 inches. About two-thirds of the rain falls from June to October. Summer rains are generally sudden, localized, brief, and intense. Winter rains are usually associated with cold fronts.

Tropical hurricanes occasionally hit the Miami area during the summer and fall. Damaging winds and heavy rains, as well as high tides, can be expected even when the hurricane center is as much as 80 miles from Miami.

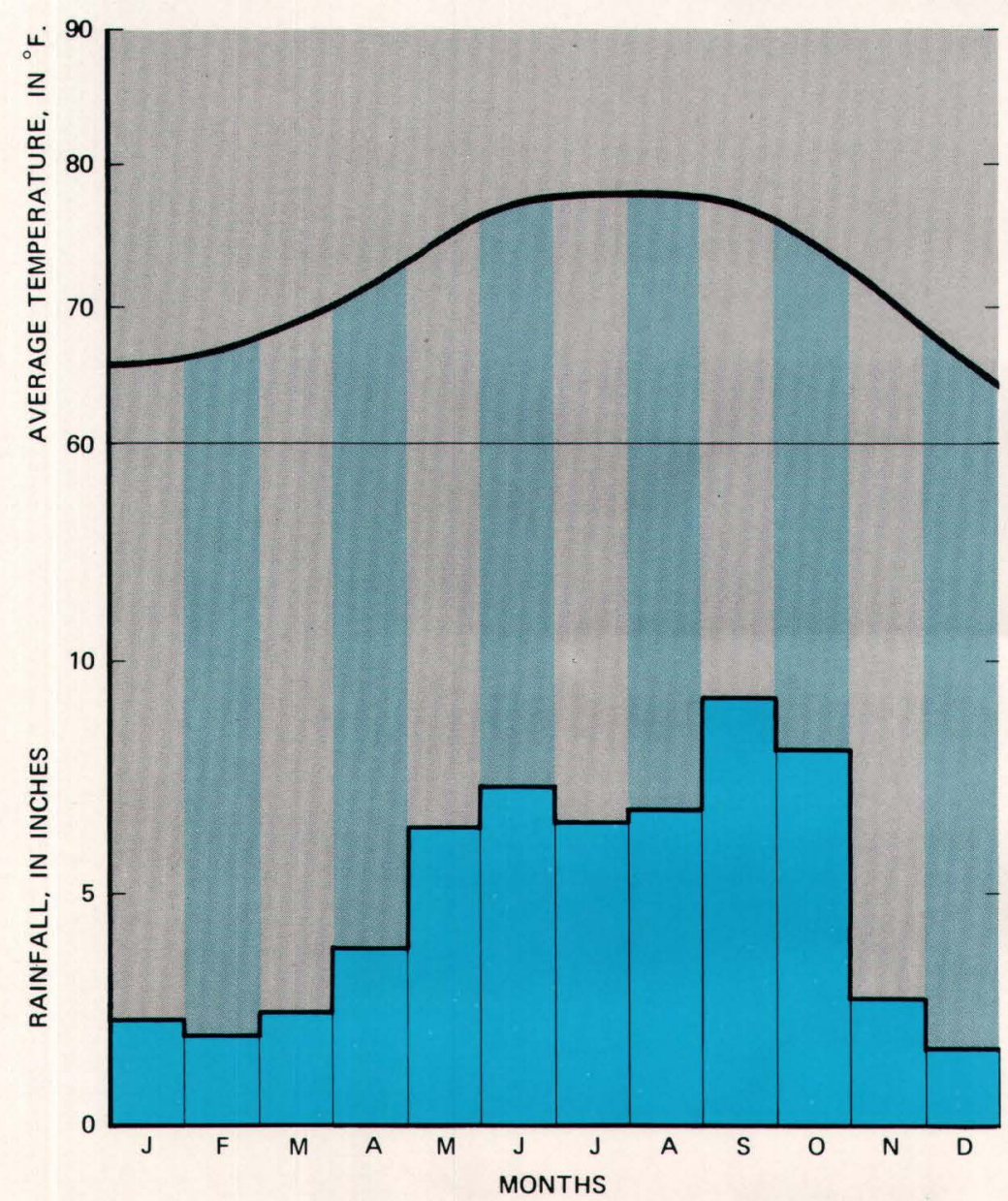

A subtropical climate has been an important factor in the explosive growth of the area.

\section{Drainage}

Before about 1900 , south Florida was poorly drained and only a few short streams existed. Drainage was mainly by sheet flow. The Everglades and coastal marshes were

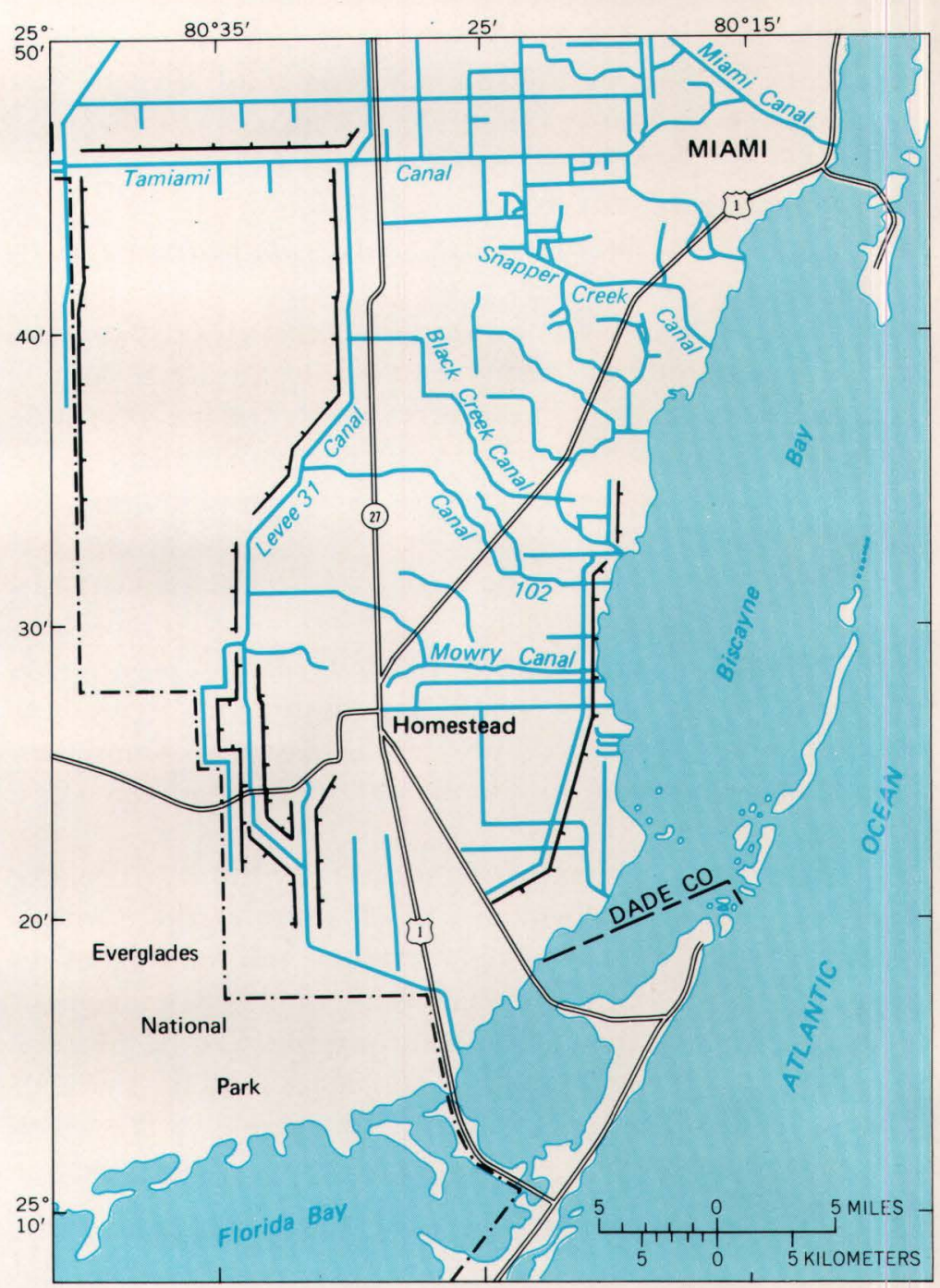

A dense network of drainage canals has greatly altered the hydrologic regimen of the south Dade area.

inundated several months during the rainy season. Most rainfall evaporated, or was used by plants or seeped into the ground.

The first major canals were dug to drain the land for farming. This lowered the water table, creating several problems. The peat soil dried, oxidized, and blew away. Salt water moved inland along the canals, infiltrating the ground and contaminating the ground water.

In response to these problems, the Dade County Water Conservation District and the Central and Southern Florida Flood Control District were established in the late nineteen forties to control floods, conserve water, and control salinity. Canals, levees, and control structures were built and waterconservation areas were established.

The flood-control and conservation facilities significantly altered the hydrologic regimen of Dade County. Although some lowlands still experience short-term flooding annually, many low areas are no longer flooded. The canal system reduces flooding by allowing water to run off rapidly, and by lowering the water table. The lowered water table increases the amount of underground space available for storage of rainfall and permits septic-tank systems to function satisfactorily. 


\section{Shape of the Land}

South Dade County is almost flat: the highest points are only 25 feet above the sea, and most of the area is less than 10 feet above high tide. The main drainageways are broad linear depressions only one to two feet deep.

The shape of the land influences the development of soil and vegetation, and is critical in the planning and construction of irrigation and flood-control structures, and in the siting of communities and their related support facilities. Six natural provinces are recognized and delineated on the accompanying map.

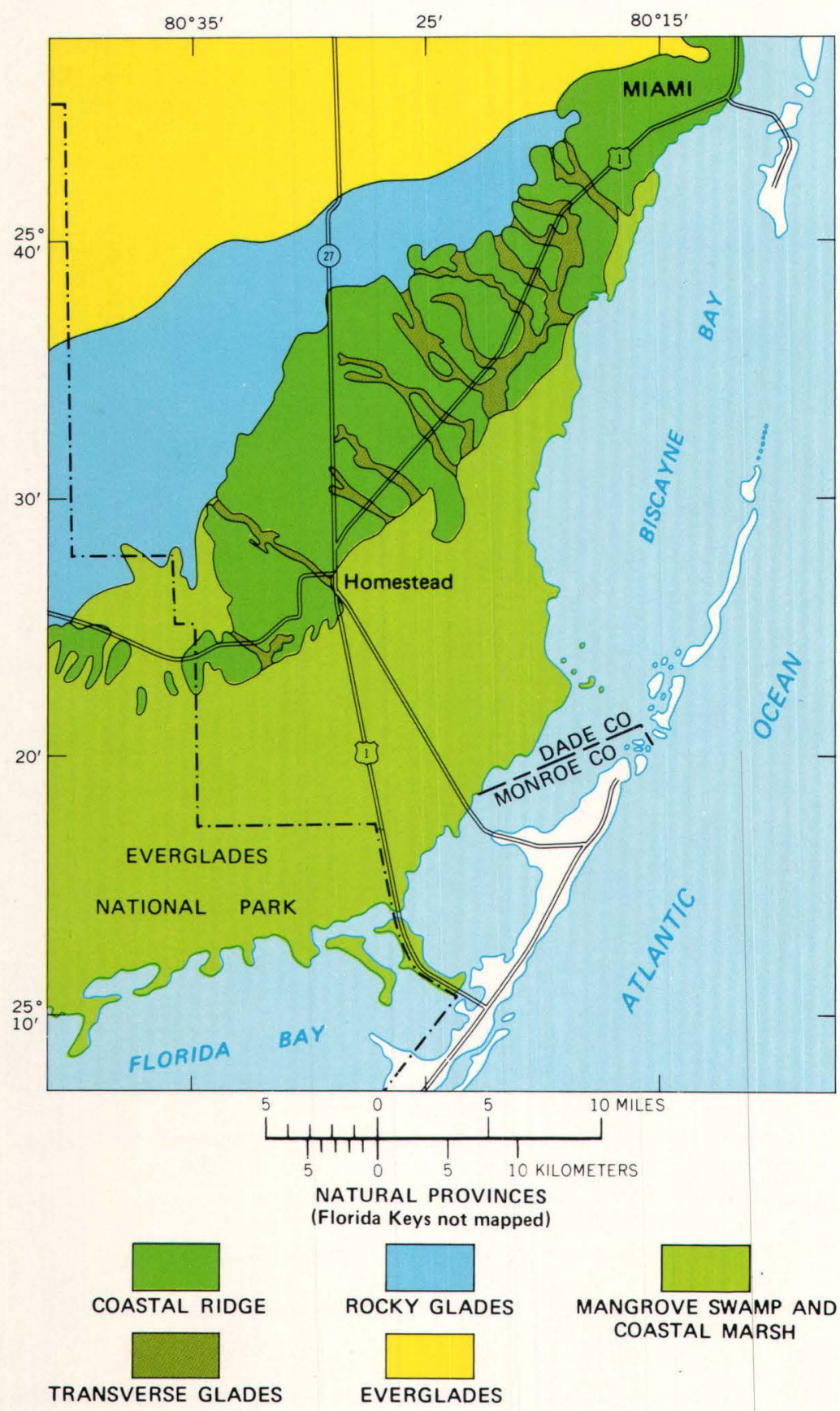

The area of and near the Coastal Ridge has been developed for urban, industrial, and agricultural use. Development of the Everglades, Rocky Glades, and Coastal Marsh has been retarded by poor drainage and a high water table. The Florida Keys (not colored) are a series of barrier islands that offer recreational opportunities for water related activities. 1

\section{The Everglades}

The Everglades is a broad expanse of grass-covered marshland dotted with tree-covered small islands or "hammocks" which rise 1 or 2 feet above the surrounding $1 /$ Numbers refer to sources at end of report. land surface. The Everglades is flat and has almost no slope; hence it floods during rainy seasons.

The Everglades is undeveloped except in a few places along its eastern edge, where flood-control canals have altered drainage. The drained parts of the Everglades are used for industry, agriculture, and homes. A considerable part of the undeveloped Everglades in Dade County has been zoned for industrial use.

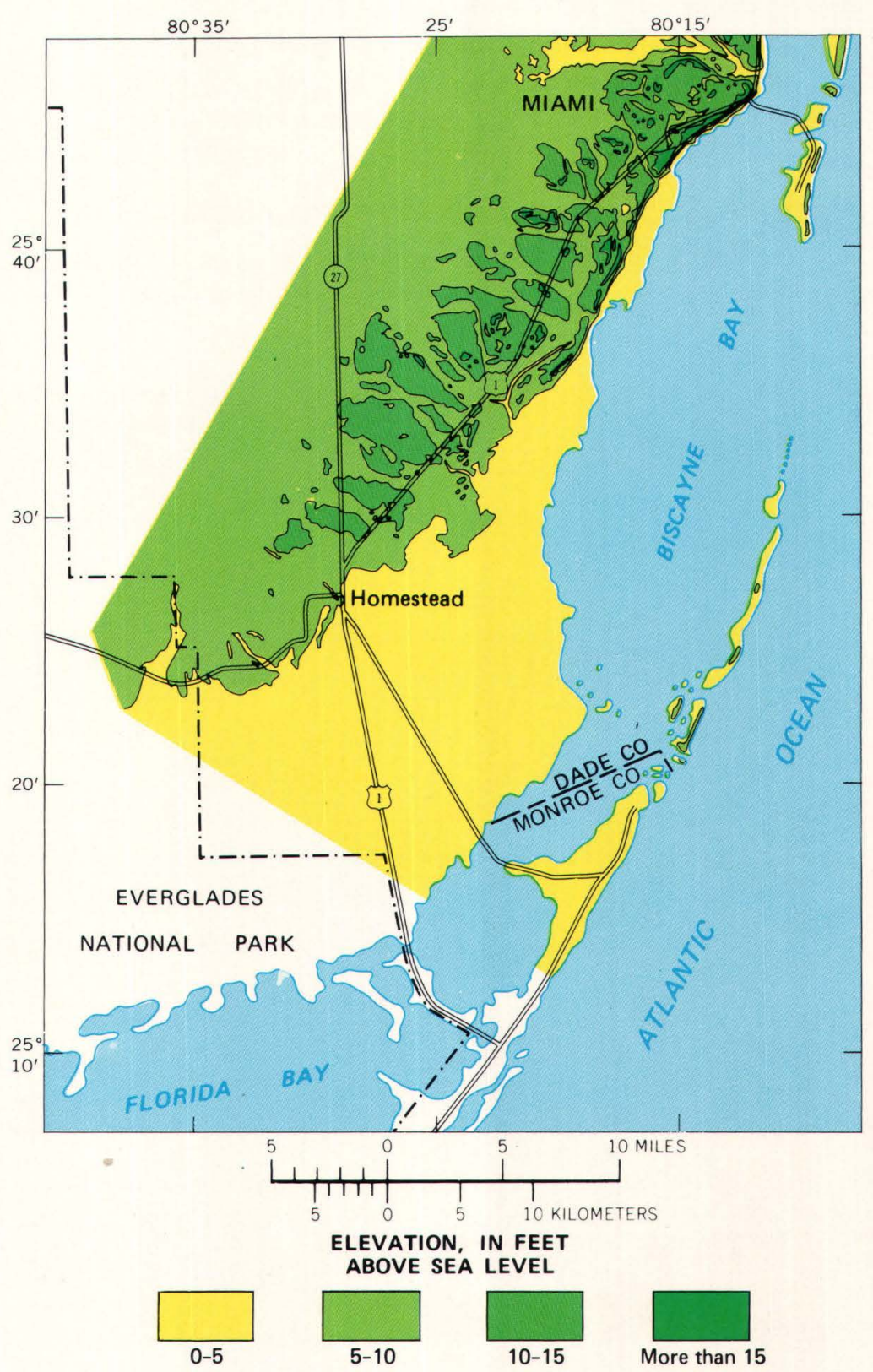

The south Dade area is very flat. The shape of the land, however, has greatly influenced the pattern of urban and agricultural development.2f

\section{Rocky Glades}

Southeast of the Everglades are the Rocky Glades, which look like the Everglades except that hard limestone protrudes through the surface. The scant soil is a few inches thick. The Rocky Glades are fairly well drained by canals. Because the limestone is near the surface, they are easier to convert to urban use than the Everglades.

\section{Coastal Ridge}

Rising above the Everglades is a low ridge, the Coastal Ridge, which is nearly parallel to the Atlantic Coast. The ridge is as much as 6 miles wide, and generally 10 to 25 feet above sea level. The highest and best drained land in the area, the ridge was the first to be settled, and most urbanization has occurred on and near it. In its natural state the 
ridge was covered by pine and hardwood forests. Today, the vegetation on the urbanized parts of the ridge is luxuriant, in places dense, and includes tropical plants along with pine and palmetto.

\section{Transverse Glades}

The Coastal Ridge is cut by low, narrow valleys or channels called the Transverse Glades in which the soils and vegetation are similar to those in the Everglades. These were once tidal channels through the Coastal Ridge.

The Transverse Glades are the sites of most major canals and the pathways of saltwater intrusion, storm runoff, and flooding near the coast.

\section{Mangrove Swamp and Coastal Marsh}

Mangrove Swamp fringes most of the coast. The Mangrove Swamp and the adjacent Coastal Marsh are poorly drained; however, the northern part of the Coastal Marsh is fairly well drained and has many farms and residences.

\section{Biscayne Bay}

Biscayne Bay is a shallow tropical lagoon about 35 miles long, as much as 10 miles wide and 12 feet deep. It is bound on the west by the Mangrove Swamp of the mainland and on the east by a series of barrier and coral islands. Near the western mangrove shore,peat, mud, and organic debris are several feet thick. To the east the bottom of much of the bay is hard with little or no sediment. Sea grasses are dense where the sediment is deepest. Algae and other marine organisms grow on the bottom.

The lands of the Coastal Ridge and the Rocky Glades are most readily converted to urban use. The peat soils of the Everglades and the marl soils of the Coastal Marsh are much less readily developed, but are more readily farmed. 3 /

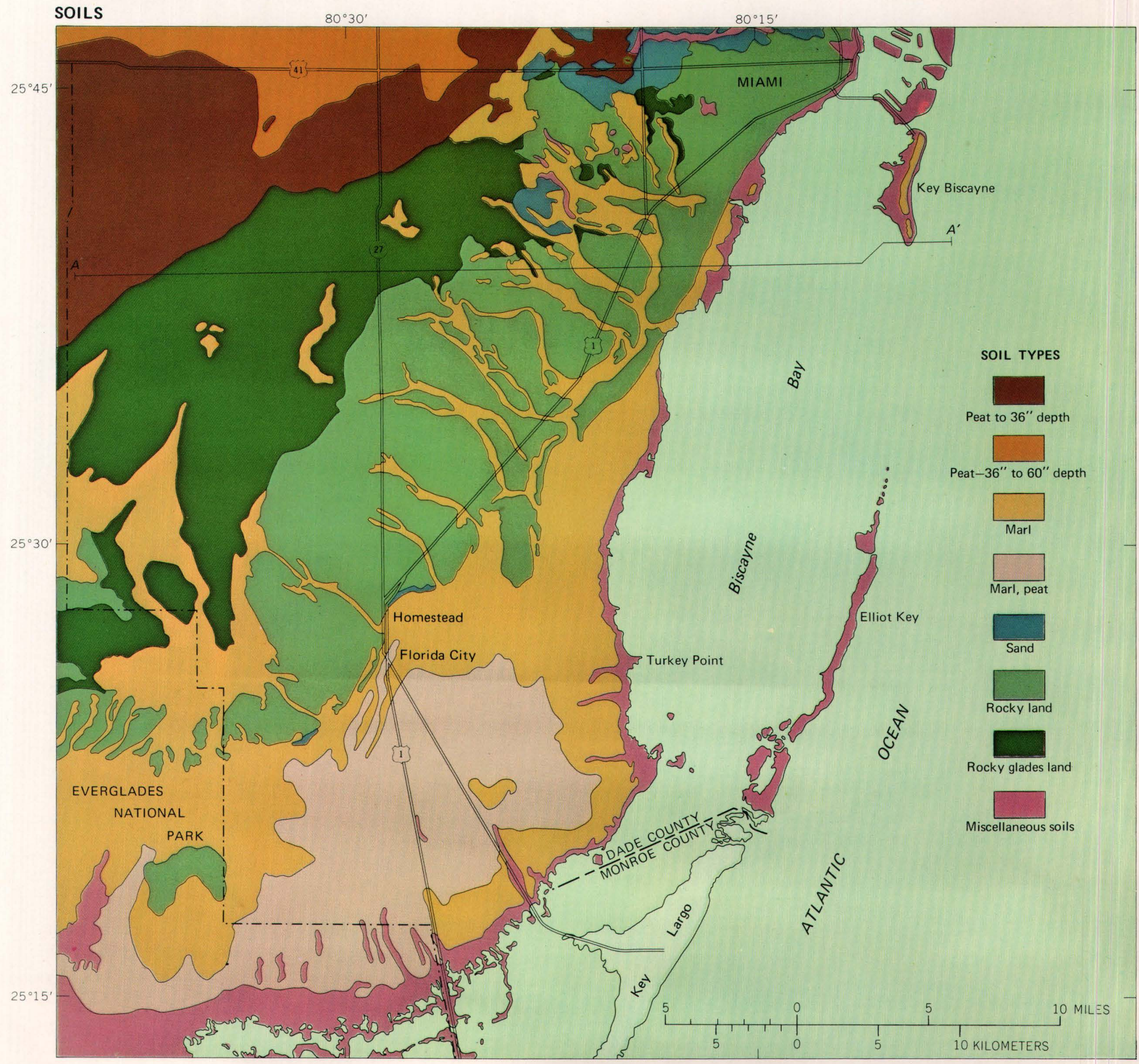




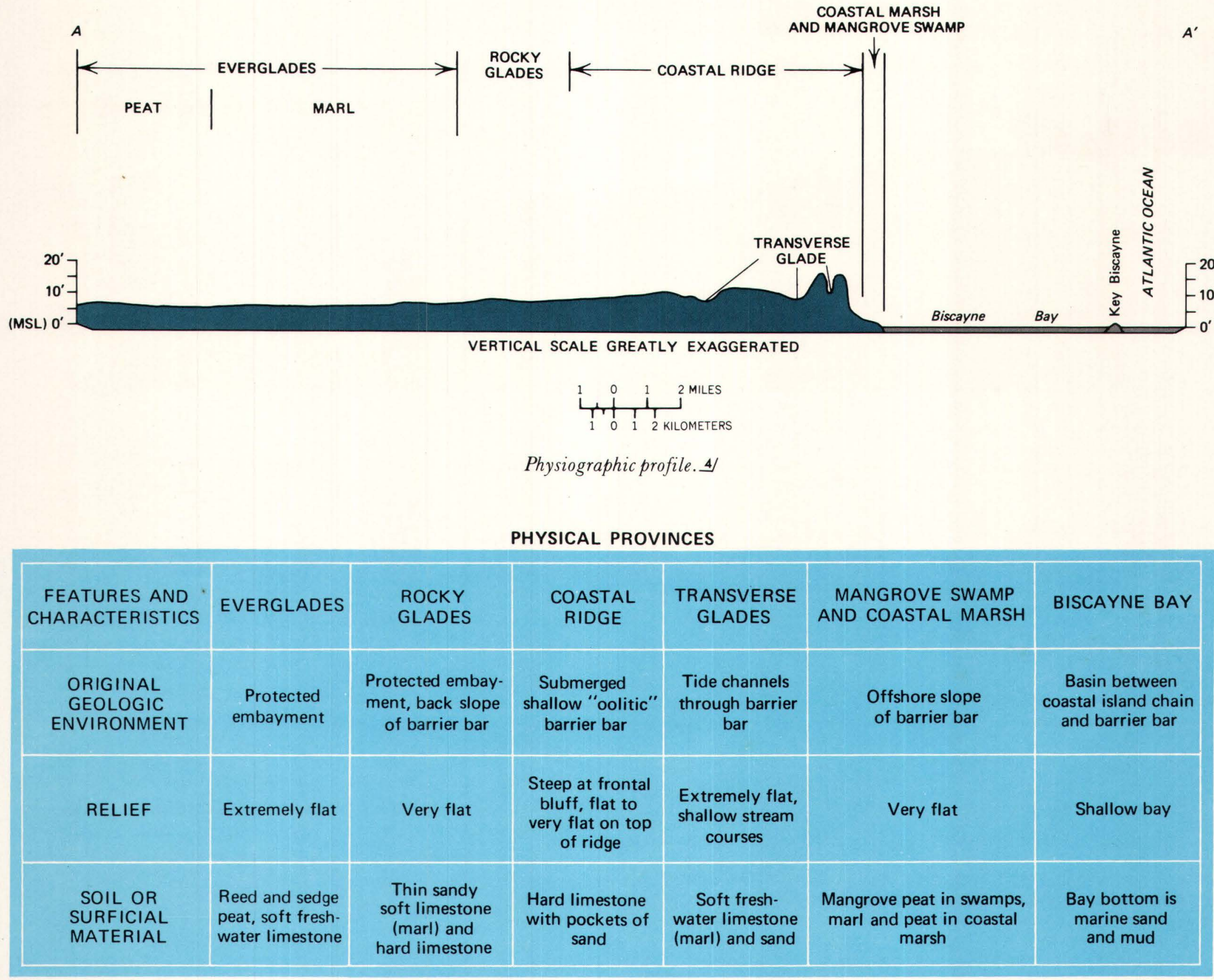

\section{Soils}

The soils of south Dade County are distinctly related to the natural province in which they occur. Soils of the poorly drained lowlands of the Everglades, the Mangrove Swamp and Coastal Marshes, and the Transverse Glades are composed largely of marl and peat. The Coastal Ridge and the Rocky Glades have almost no arable soil. The soil that is present generally consists of a veneer of marl, peat, sand and finer materials over pitted limestone.

Despite the paucity of arable soil, farming is practiced on both the Coastal Ridge and Rocky Glades. A rudimentary soil, suitable for row crop cultivation, is created by mechanically pulverizing the limestone and mixing it with whatever sand, silt, clay, marl,and organic debris is naturally present. Domestic gardens and lawns are dependent largely on the import of soil and sod.

Farming is extensively practiced on the flat marl soils south and east of Homestead.

Farming throughout the region requires frequent application of fertilizer, enriched in many trace element additives, including iron.

\section{Geology}

The southern half of Florida is the exposed part of a huge plate of shallow-water marine limestone that extends far under the shallow portions of the Gulf of Mexico but terminates abruptly at the Straits of Florida. This limestone plate is 15,000 feet thick in Dade County and zones within it are sources of water, potential sources of petroleum and natural gas, and potential reservoirs for the disposal of waste.

Limestone crops out in most of south Dade County (see map). Hard limestone forms the Coastal Ridge and outcrops in the Rocky Glades. Soft limestone or marl underlies most of the Everglades and the Coastal Marsh. Peat covers the limestone in the northwest part of the area and underlies Mangrove Swamp along the coast. Patches of quartz sand are scattered on the Coastal Ridge and in the Transverse Glades. Shelly sand and mud are exposed on the Keys (Islands) in the northeast, and underlie much of the Bay. 


\section{THE PHYSICAL SETTING}

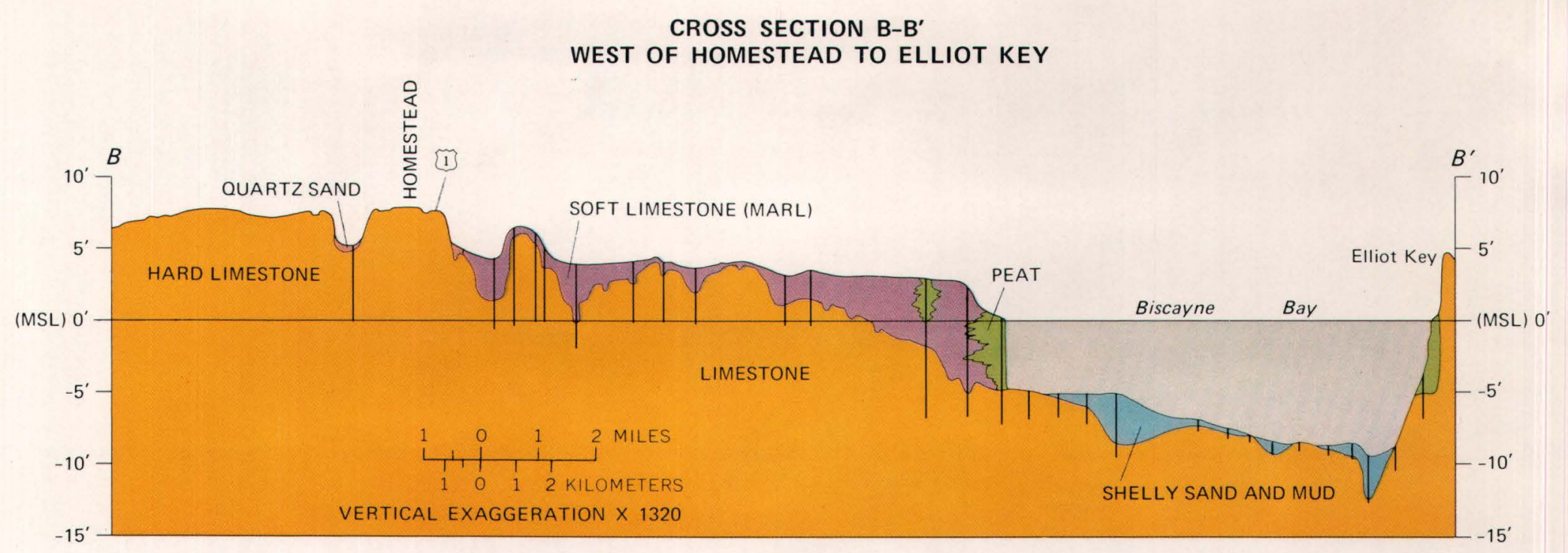

A thin layer of soft limestone covers the hard limestone throughout most of the area (see map on facing page for location of section). Vertical lines are drill hole sites.

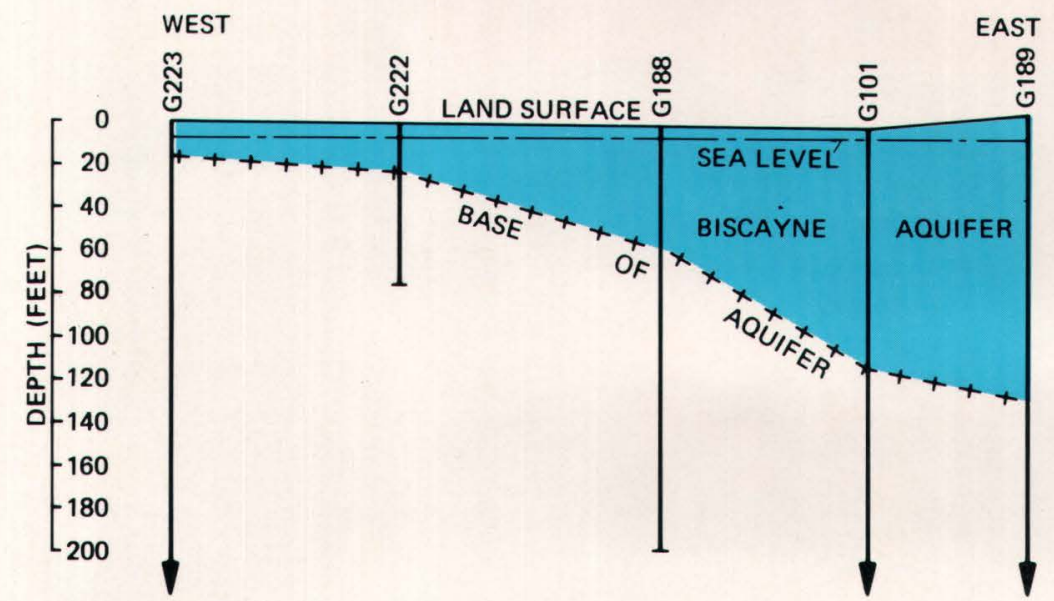

The Biscayne aquifer ranges from about 10 feet thick in the western part of the area to about 120 feet thick at the coast.

Chemical analyses of six hard and soft limestones are presented in the adjacent table. The hard limestone is very pure. The soft limestone contains considerable peat. The elements that make up clays, quartz sand, metallic minerals, and nutrients are conspicuously sparse. Certain elements of importance to animal and plant health, such as arsenic and mercury, are probably present in trace amounts, below detectability by the methods used.

The hard limestone and sandy limestone below it, which is not exposed at the surface here, together constitute the principal source of water, the Biscayne aquifer.

Another aquifer, the Floridan aquifer, is separated from the Biscayne by about 800 feet of rock that does not yield water. Much thicker than the Biscayne, the Floridan aquifer contains only brackish and salt water.

\section{Chemical Composition}

The compositions of rocks and soils influence mineral resource use, water quality, the nutritional value of farm produce, and the safety of the environment.
The chemical analyses below are representative of the limestones in Dade County. They are relatively pure except for peat components in the soft limestones (marls), reflected in high organic matter, and sparse quartz sand, shown by silica $\left(\mathrm{SiO}_{2}\right)$. Elements making up clays, metallic minerals, and nutrients $\left(\mathrm{K}_{2} \mathrm{O}, \mathrm{P}_{2} \mathrm{O}_{5}\right)$ are generally low. Such limestones provide little residuum upon weathering. The farmed marls require much fertilizer, containing iron as well as conventional additives. Potentially harmful elements such as arsenic and mercury are insignificant in these rocks.

\section{Ground Water}

The limestones near the surface are coarse-grained shelly rocks containing many cavities. Many are capable of holding and transmitting much water. These rocks make up the Biscayne aquifer, which is as much as 120 feet thick under Miami but thins to a few feet in western Dade County. The rocks below are finer grained, less permeable, and seal off aquifers.

\begin{tabular}{|c|c|c|c|c|c|c|}
\hline \multicolumn{7}{|c|}{$\begin{array}{l}\text { CHEMICAL ANALYSES OF LIMESTONES FROM DADE COUNTY, FLORIDA } \\
\text { ANALYSTS: U.S. GEOLOGICAL SURVEY }\end{array}$} \\
\hline & \multicolumn{3}{|c|}{ HARD LIMESTONE } & \multicolumn{3}{|c|}{ SOFT LIMESTONE } \\
\hline & 1 & 2 & 3 & 4 & 5 & 6 \\
\hline & $\begin{array}{l}\text { Windley Key } \\
\text { Quarry, } \\
\text { Windley Key }\end{array}$ & $\begin{array}{c}\text { Cutler Ridge } \\
\text { Road, } \\
\text { Coral Gables }\end{array}$ & \begin{tabular}{|c|} 
Borrow pit, \\
Campbell Dr., \\
east of \\
Homestead
\end{tabular} & $\begin{array}{c}\text { Campbell Drive, } \\
\text { east of } \\
\text { Homestead }\end{array}$ & $\begin{array}{l}\text { Taylor Slough, } \\
\text { Everglades } \\
\text { National Park }\end{array}$ & \begin{tabular}{|c|} 
Florida City \\
Canal, west of \\
Homestead Bay \\
Front Park \\
\end{tabular} \\
\hline $\mathrm{CaO}$ & 54.1 & 52.6 & 54.8 & 51.1 & 50.6 & 36.6 \\
\hline $\mathrm{MgO}$ & .20 & .73 & .17 & .60 & 30 & .60 \\
\hline $\mathrm{MnO}$ & .01 & .06 & .04 & .13 & .12 & .12 \\
\hline $\mathrm{Na}_{2} \mathrm{O}$ & .46 & .03 & .00 & .04 & .00 & .03 \\
\hline $\mathrm{K}_{2} \mathrm{O}$ & .03 & .05 & .05 & .04 & .04 & .06 \\
\hline $\mathrm{SiO}_{2}$ & .00 & 5.0 & .64 & .14 & 2.1 & 4.9 \\
\hline $\mathrm{Al}_{2} \mathrm{O}_{3}$ & .00 & .00 & .10 & .26 & 3.2 & 3.3 \\
\hline $\mathrm{Fe}_{2} \mathrm{O}_{3} \stackrel{a}{-}$ & .17 & .10 & .17 & .22 & 1.1 & 1.6 \\
\hline $\mathrm{TiO}_{2}$ & .00 & .00 & .00 & .05 & .15 & .15 \\
\hline $\mathrm{CO}_{3}$ & 43.1 & 41.0 & 43.8 & 39.6 & 37.7 & 28.1 \\
\hline $\mathrm{SO}_{4}$ b/ & .50 & .00 & .00 & .05 & .03 & .18 \\
\hline $\mathrm{P}_{2} \mathrm{O}_{2}$ & .00 & .01 & .01 & .19 & .03 & .14 \\
\hline $\mathrm{H}_{2} \mathrm{O}+\underline{c}$ & 1.6 & .42 & .25 & .89 & 1.5 & 5.7 \\
\hline Organic Matter & ND & ND & ND & 6.8 & 3.2 & 18.8 \\
\hline F & .09 & .01 & .01 & .00 & .00 & .00 \\
\hline Sum & 100.26 & 100.01 & 100.04 & 100.11 & $100.0^{7}$ & 100.28 \\
\hline $\begin{array}{l}\text { a/-Includes } \mathrm{FeO} \\
\text { b/-Includes } \mathrm{S} \\
\mathrm{c} /-\mathrm{H}_{2} \mathrm{O}+\text { at } 110^{\circ} \\
\mathrm{ND} \text { not determine }\end{array}$ & med & to analysis & & & & \\
\hline
\end{tabular}




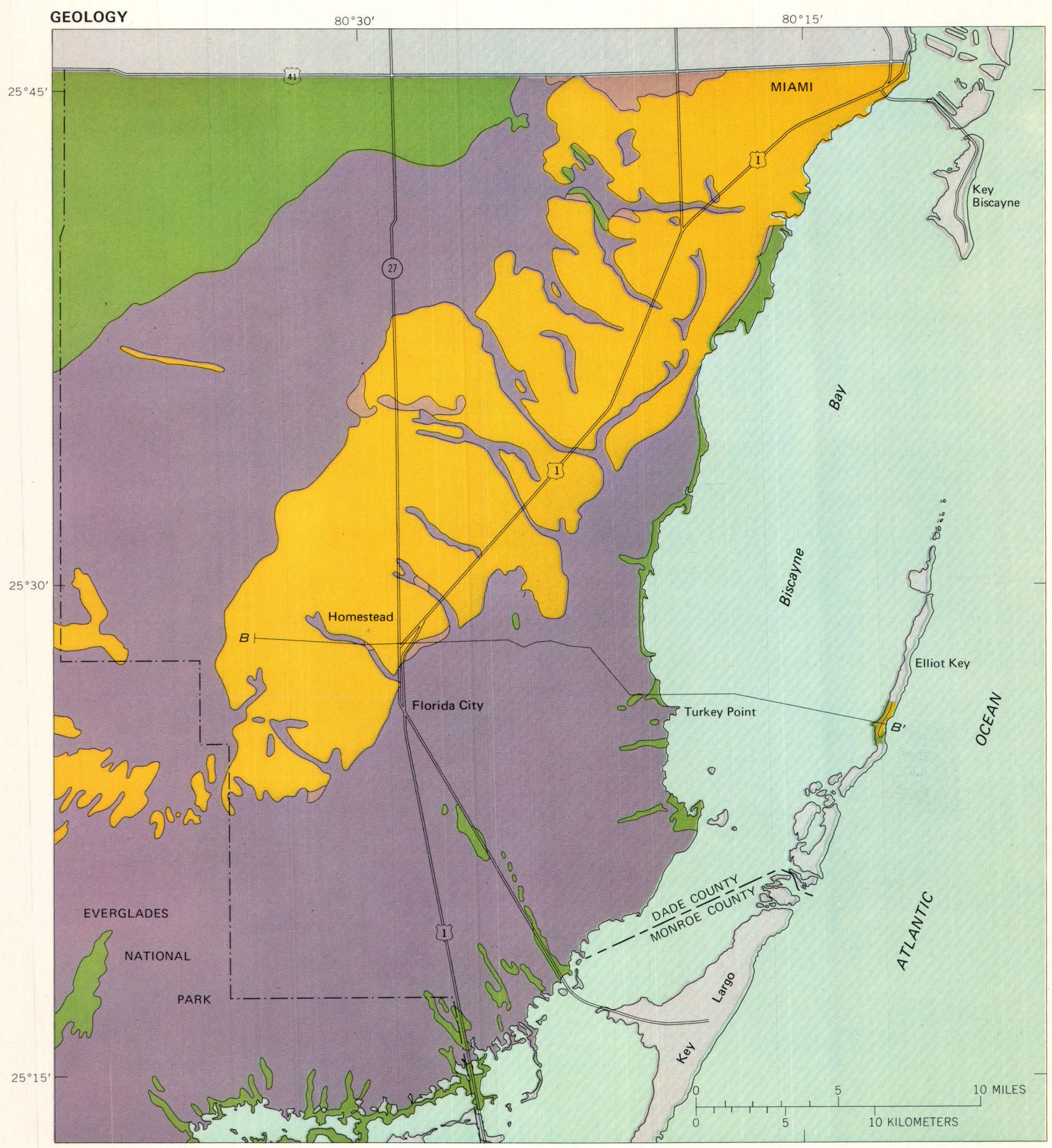

EXPLANATION

(Geology of offshore islands not mapped.)
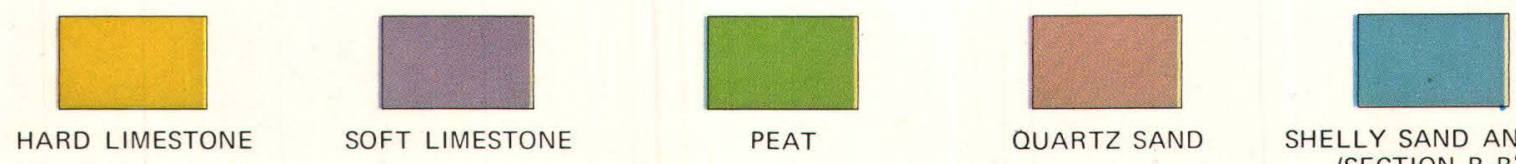

SHELLY SAND AND MUD (SECTION B-B')

The surface of most of south Dade County is hard limestone, soft limestone, and peat. Small patches of quartz sand, shelly sand, and mud are present in some areas. Note: Barrier islands not mapped. 


\section{URBANIZATION}

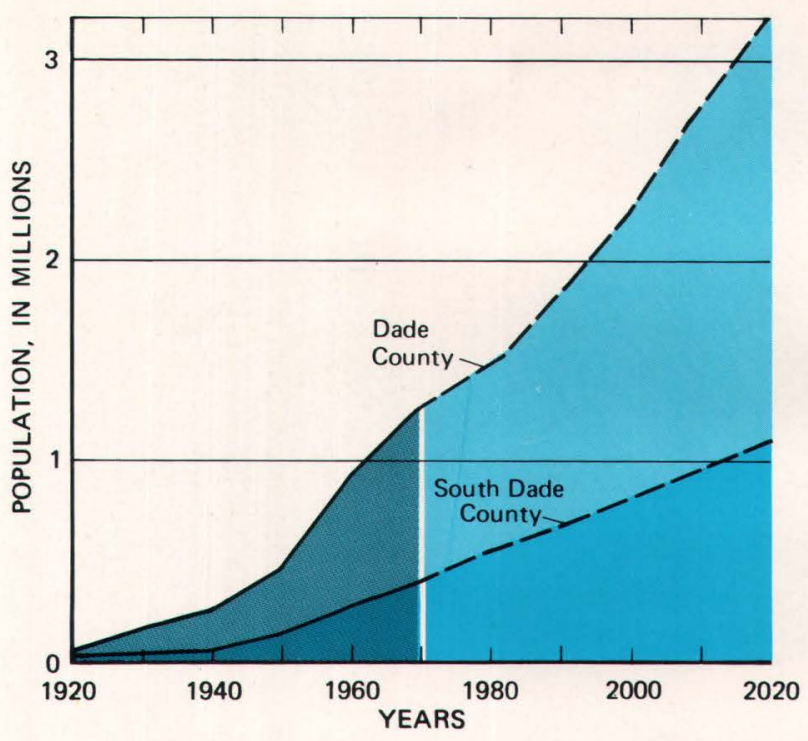

The ever-increasing population is causing increased stress on the natural resources of the area. $1 /$

Each year tens of thousands of people move to south Florida, and thousands are born there. Providing the necessary housing, schools, transportation facilities, and related public services for the new residents requires land and other natural resources. The faster the population grows, the greater the strain on the already taxed natural resources.

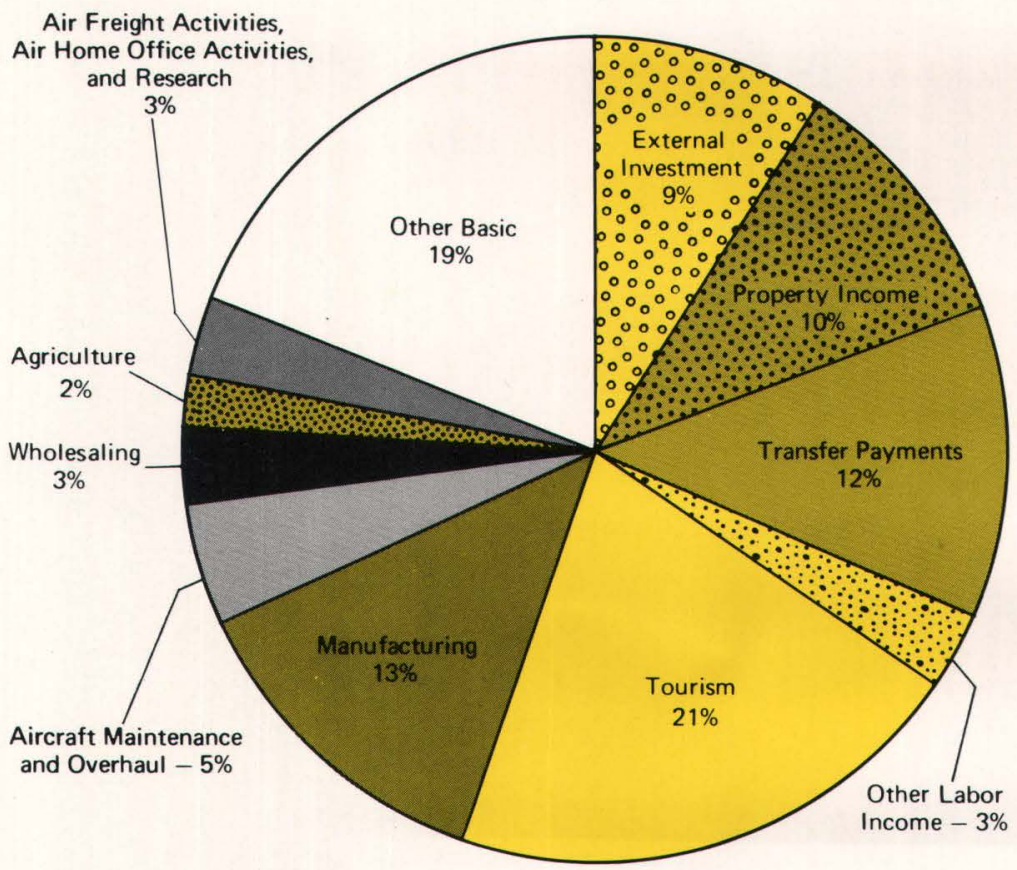

Dade County's broad base of economic activity should continue to stimulate growth in the future. 2 /

Urbanization brings a host of interrelated resource problems, such as land development, water supply, waste disposal, flood protection, water management, environmental degradation, and pollution. In south Florida, as in the rest of the country, an increased awareness of the consequences of urbanization is leading to changing concepts of urban planning and resource management, emphasizing conservation and wise use of our natural resources. The rapid growth of the area requires immediate responses and decisions now and will continue to do so. Land use alternatives must be evaluated now if south Florida is to go on being a good place to live.

\section{Trends in Urban Growth}

Dade County's sunny weather and sandy beaches attract more than 8 million visitors each year, and many become permanent residents. For a long time, income from tourism and from pensions and annuities of retirees accounted for most of the economic base. However, recent expansion of industrial and commercial enterprises into national and international markets has created an income base exceeding that supplied by tourism and retirees.

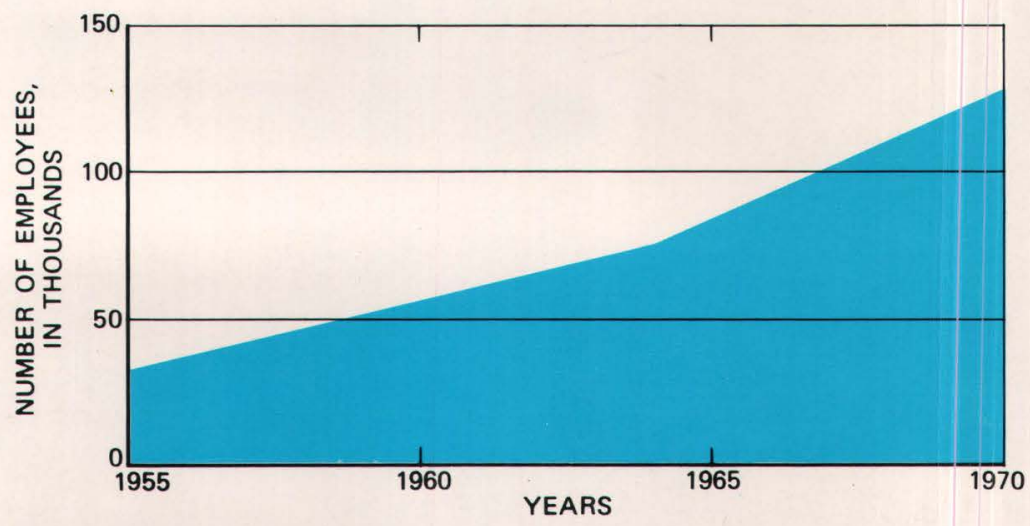

The large increase in the number of employees of manufacturing firms in the past decade is one indication that the base of economic activity is expanding and broadening. 2/

Climate and location are key factors in the rapid commercial and industrial growth. Miami is the gateway to South and Central America, through its seaport facilities and direct airline connections to most of the trade and marketing centers there. Ready access to foreign markets has induced many large firms to locate national and international offices here. Nearly 4,000 small manufacturing firms serve national markets as well as those in the Caribbean islands, the Bahamas, and Latin America. Further, a large air transport maintenance and service industry has developed.

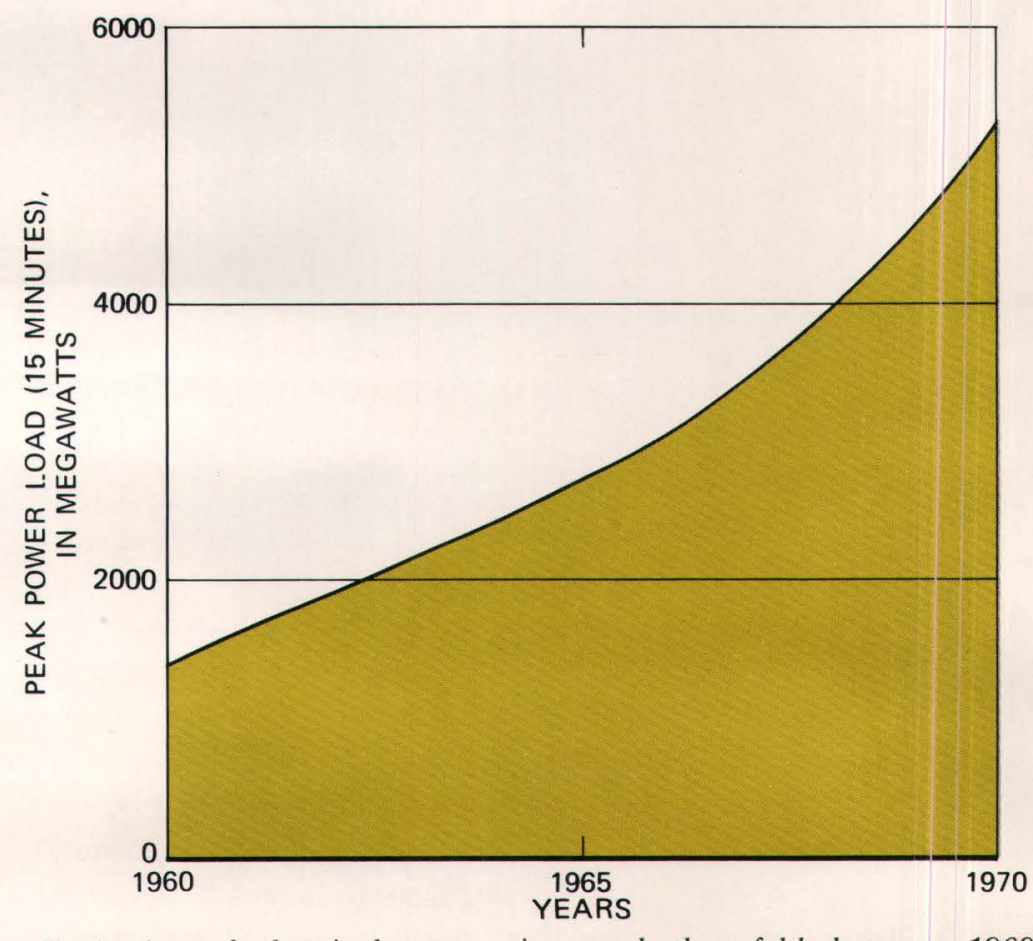

Production of electrical energy increased three-fold between 1960 and 1970. 


\section{Water Use}

In 1970 all of Dade County used about 275 mgd (million gallons of water each day) from public supplies as well as millions of gallons pumped from private wells. About $230 \mathrm{mgd}$, from public supplies, was used for household, commercial, and industrial needs, and $45 \mathrm{mgd}$ for irrigation.

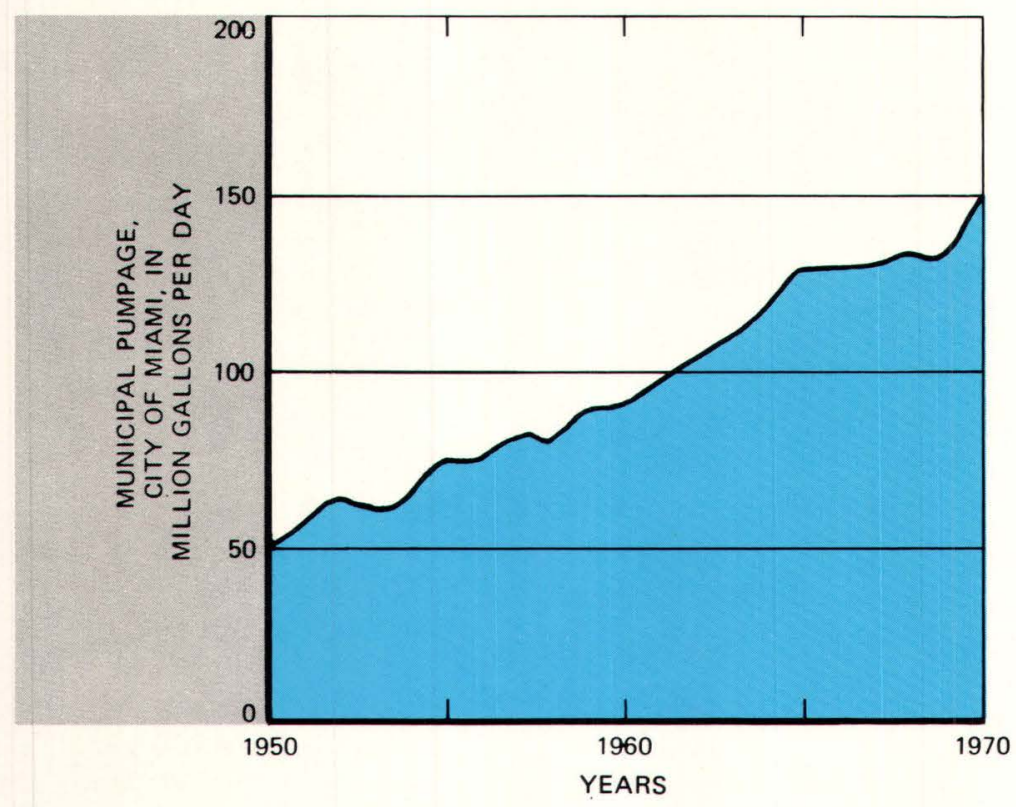

The ever-increasing demands for water will require increasingly complex water-management systems.

Nearly all of the irrigation water was used in south Dade County; but only about one-third of the water for other uses. Agricultural use will probably decrease as urban development increases. Much recreational use is made of south Dade's waterways. The significance of such use is best viewed, not in volume of water, but in terms of adequacy to meet projected demands as discussed later.

\section{Liquid-Waste Disposal}

Half of the residents of south Dade County are served by sewers, half by septic tanks. Of about $80 \mathrm{mgd}$ of wastewater produced, about $40 \mathrm{mgd}$ is collected by sewers and treated. Of 29 sewage treatment plants, 15 discharge effluent into inland canals, 12 discharge into drainfields, one (the city of Miami's Virginia Key plant) discharges into the ocean, and one employs deep-well injection. The environmental aspects of liquid-waste disposal are discussed later.

\section{Solid Waste}

In addition to liquid wastes, about 1,000 tons of solid waste are generated each day. At a compacted density of 40 pounds per cubic foot, the daily volume of refuse is 50,000 cubic feet-enough to cover a football field with about a foot of compacted solid waste.

\section{Transportation}

Highway transportation is the principal means of access to south Dade County, via U.S. Highway 1, Palmetto Expressway, Krome Avenue, and Old Cutler Road. These routes are heavily used, and rush-hour delays are prevalent. Congestion is little relieved by the present mass-transit system, which consists of buses travelling on these congested roads.

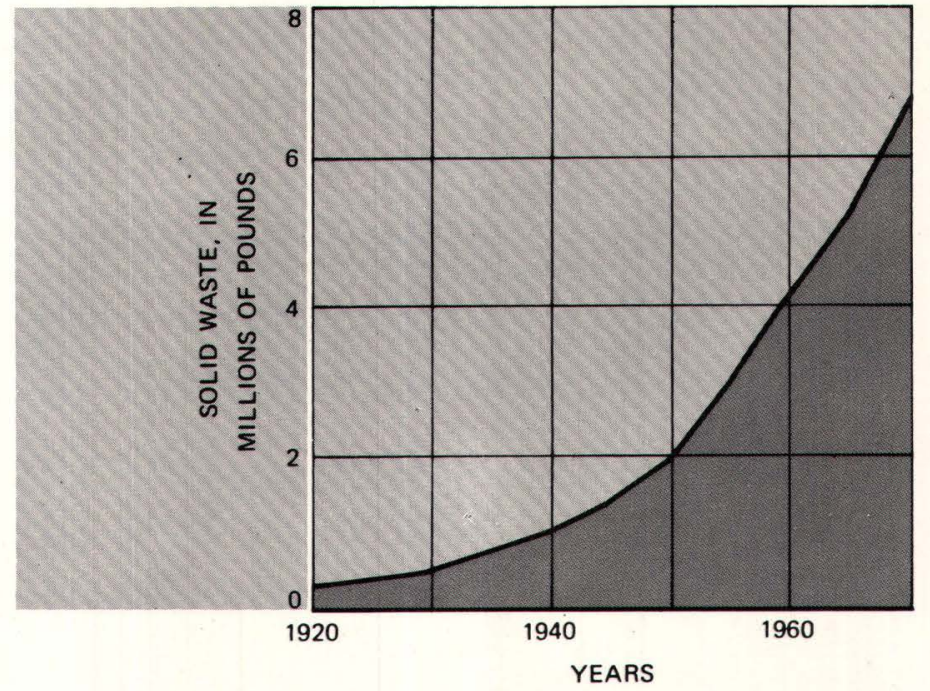

Disposal of ever-increasing amounts of solid wastes will tax the natural resources of the area.

Transportation routes have stimulated growth by providing ready access. Additional routes, both proposed and under construction, and a proposed mass-transit system will further improve access, which in turn will sustain past trends of rapid urbanization.

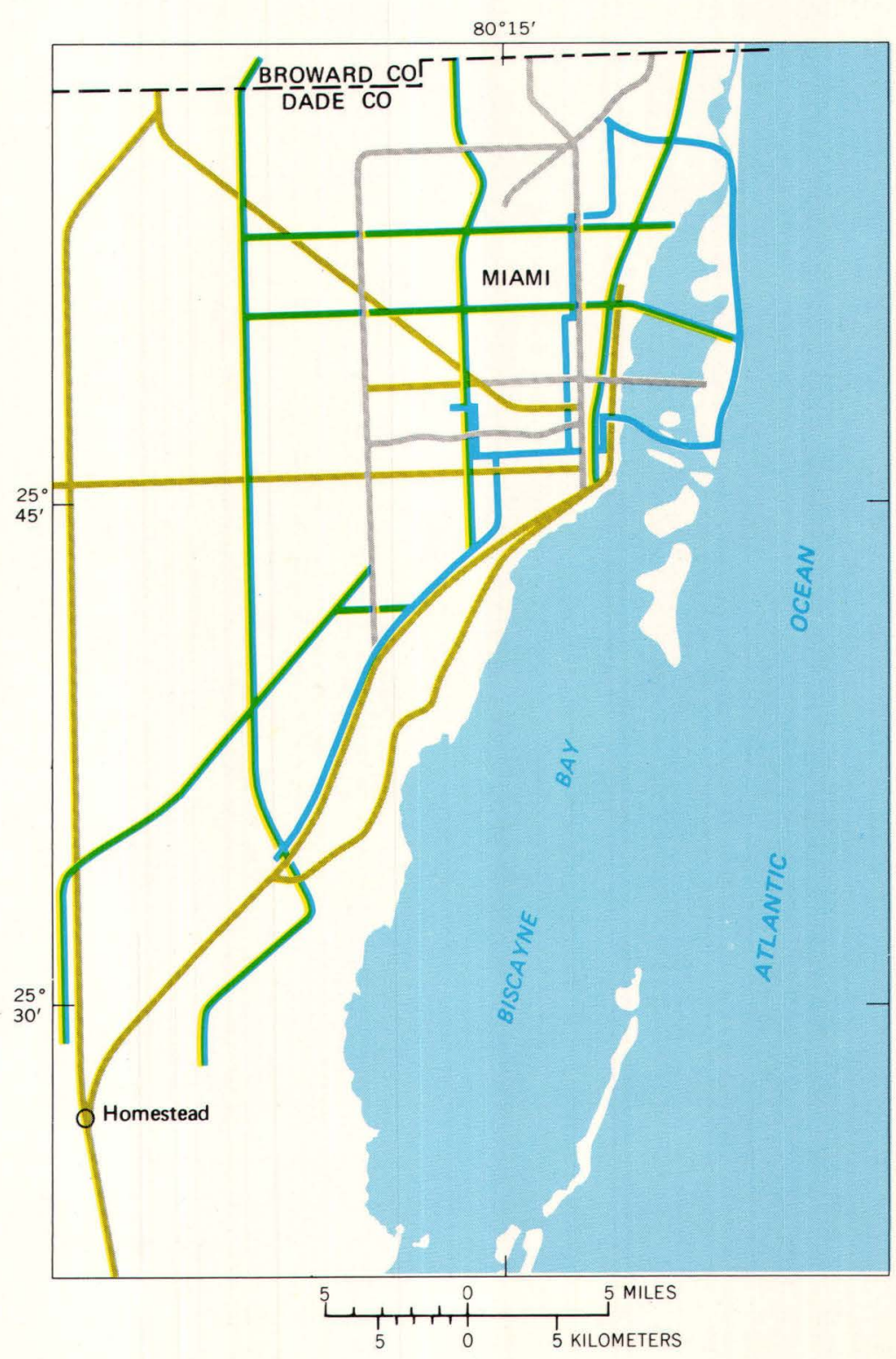

MAJOR TRANSPORTATION ROUTES 3 /

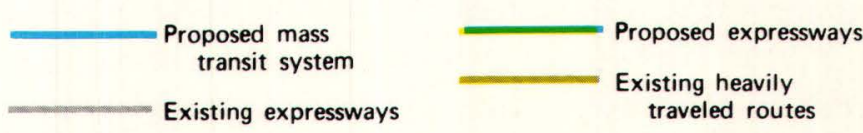




\section{URBANIZATION}

\section{Land Use}

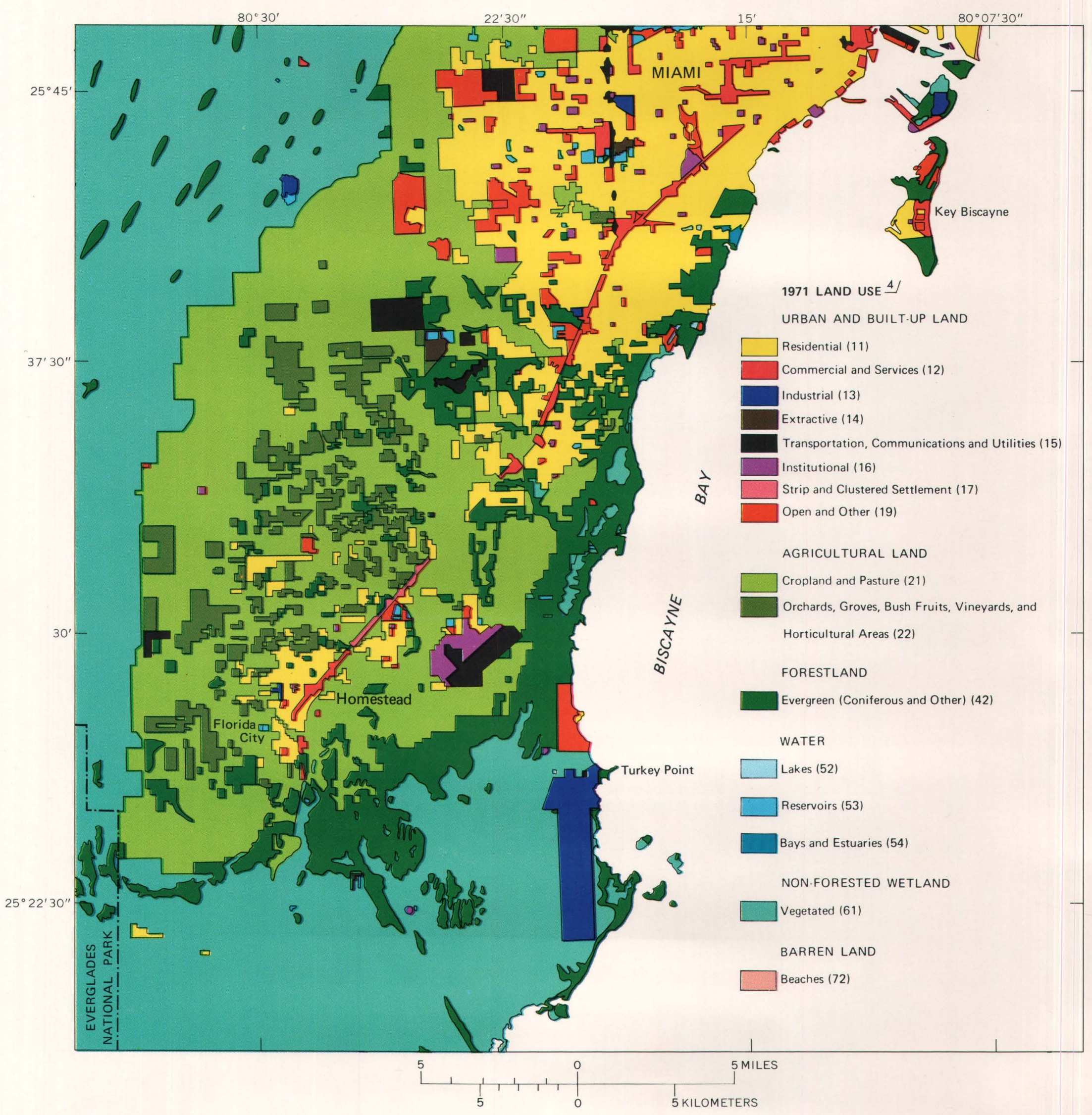

\section{Land Use in 1971}

Most of the urban land is residential. Strips of commercial and industrial land follow major transportation routes. Industrial, extractive and other urban uses are minor. Land along the fringe of the urban area is used for both row crops and tropical fruit groves. Agriculture generally terminates at the canals that border the Everglades. Sawgrass wetlands constitute the natural land of the Everglades in the area. The hammocks within the Everglades are sparsely forested with smäll trees. 


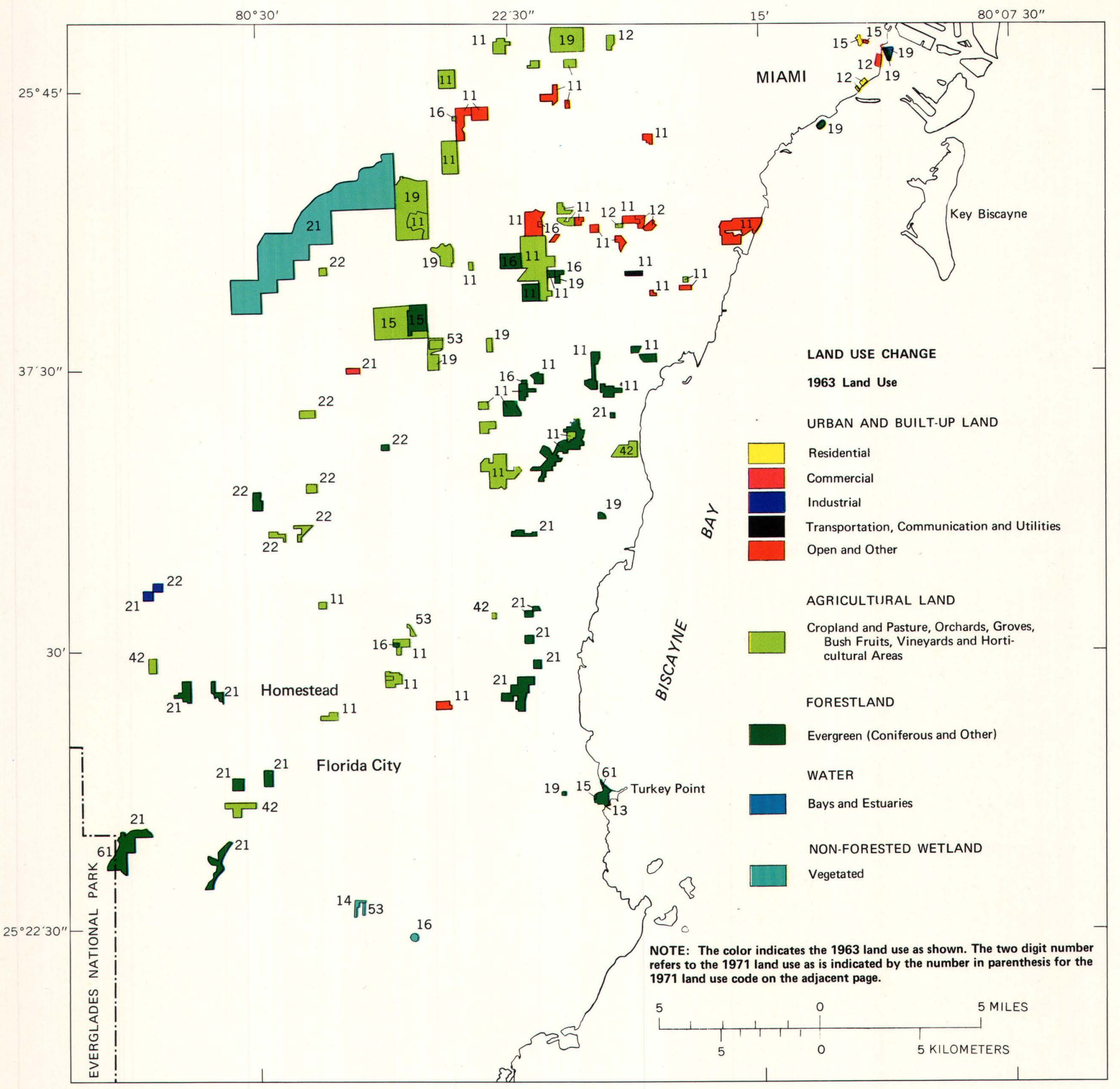

\section{Land-Use Changes 1963-1971}

Recent land-use changes may be appraised by comparing use as shown on aerial photographs taken in 1963 with use as determined by the 1970 census, aided by photographs taken in 1971. Not all changes are evident on the aerial photographs so that the changes identified do not reflect the total changes of the area.

The change in land use since 1963 is primarily a decrease in open land and an increase in urban built-up land. The numbers for each polygon of change indicate the land use corresponding to that of the 1971 map on the adjacent page, and the colors of the polygons correspond to the 1963 land use. The land use for that part of the map shown in white was the same in 1971 . The predominance of shades of green and orange above indicates that much land previously covered by some form of vegetation has changed to urban and built-up land since 1963. A major exception is the areas of sawgrass wetlands which have been drained and converted to agricultural use since 1963. Some forestland has changed to agriculture and to residential and other urban use. The orange polygons are indicative of increases in built-up land in the urban area. In most instances open urban land was converted to residential developments. In general, the residential density has increased in the urban area and urbanization is extending westward into former agricultural land. In turn, new agricultural lands are extending westward into the natural Everglades area. 


\section{URBANIZATION}

\section{Land-Use Trends}

In the urbanized area as delineated in the 1970 census of population, residential and commercial land has increased at the expense of agricultural and urban open land.

In the incorporated places about 66 percent of the landuse change has been on open urban land, 13 percent on cropland, 7 percent on forestland, and 14 percent on other land uses.

In the unincorporated areas the land-use changes have been on 43 percent of the open urban land, 27 percent on cropland, and 30 percent on forestland.

These percentages refer to the nature of the changes and not to the land use changes as these relate to the total area.

In general the trends show an increasing residential density and a westward expansion of the built-up and agricultural areas encroaching on the natural Everglades area.

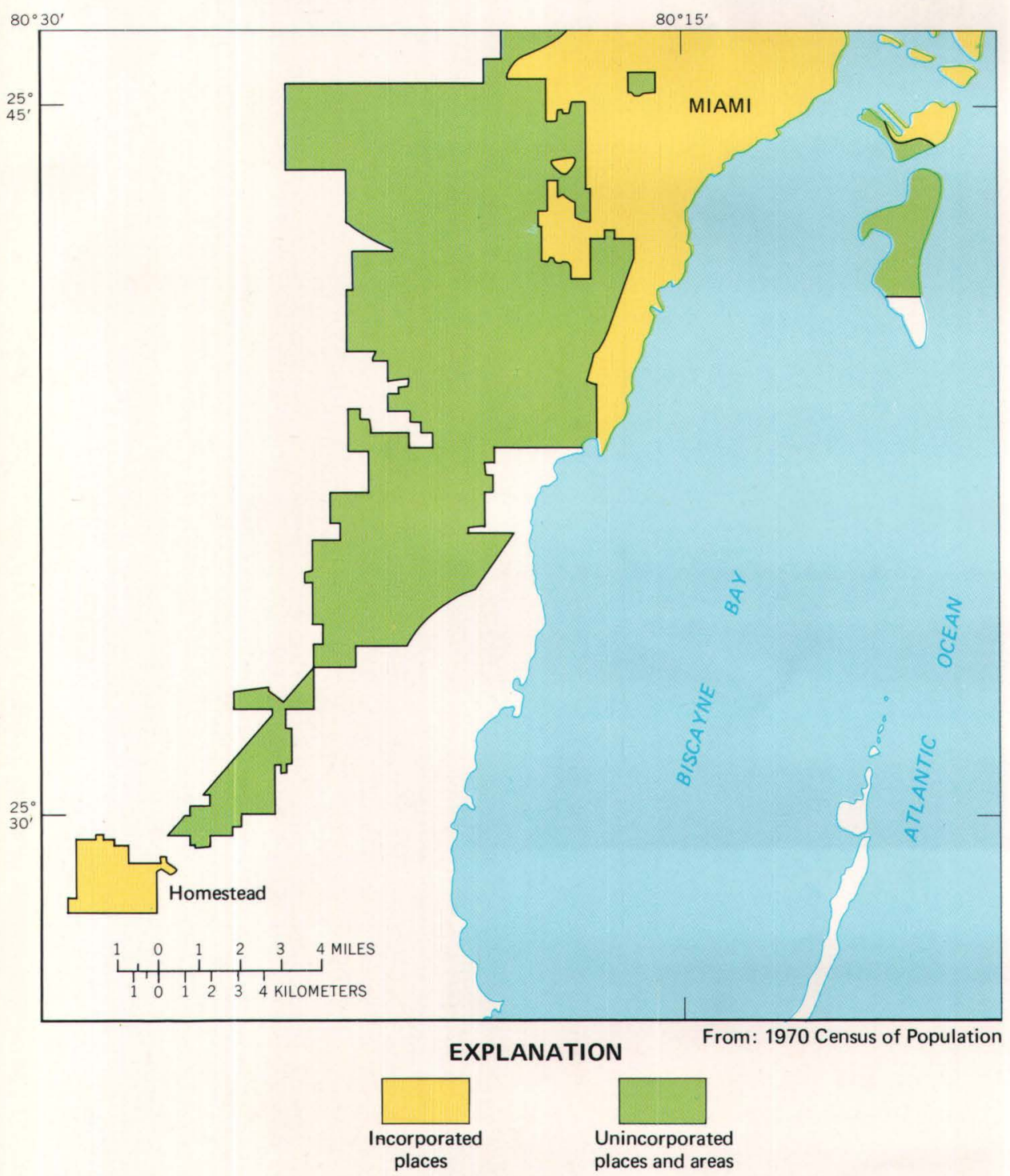

Most of the urbanized areas of south Dade County are not included in incorporated communities.
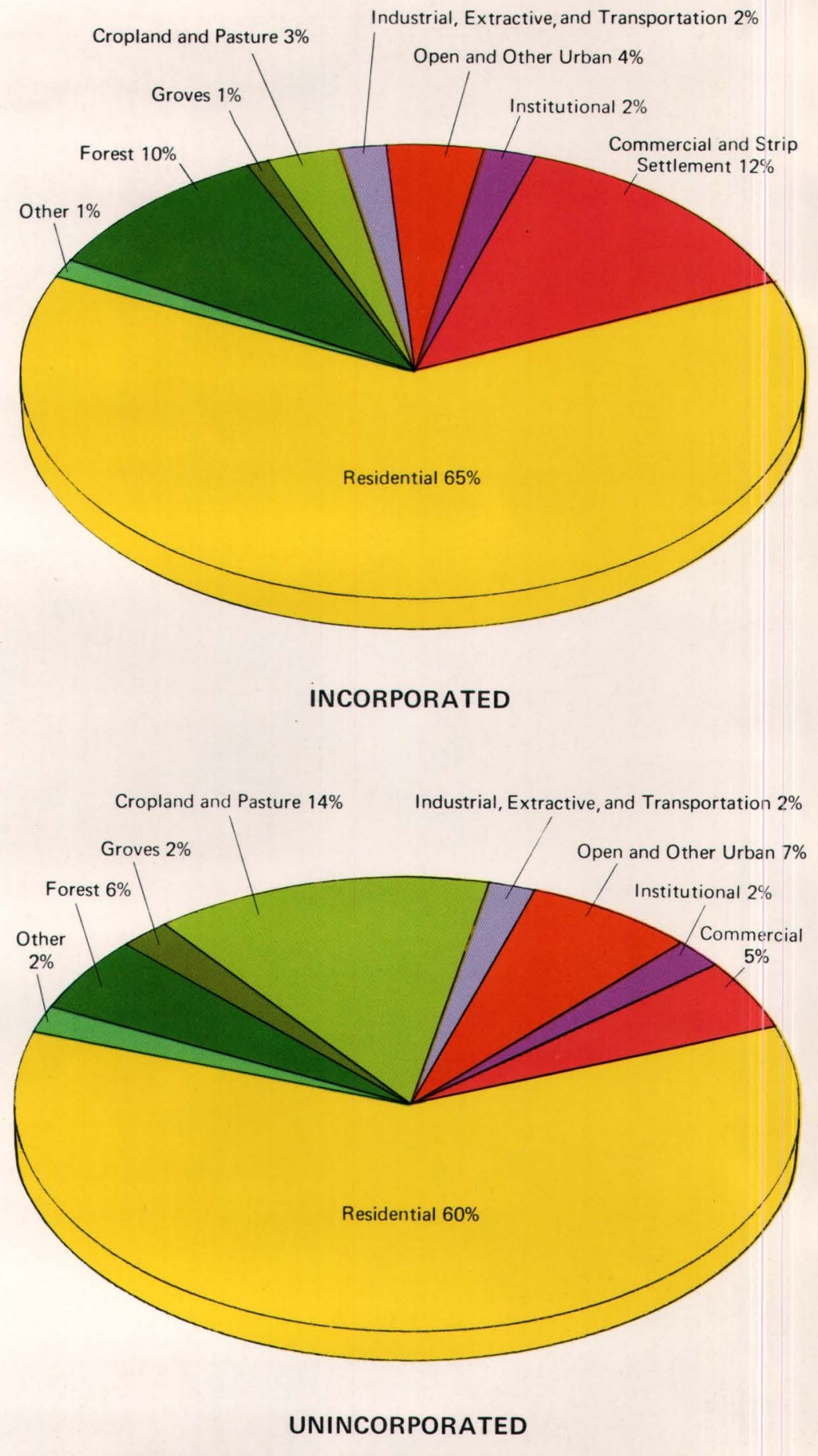

The diagrams of percent of land use in urbanized areas in 1970 show that the unincorporated areas include much more open and agricultural land than the incorporated areas.

\section{Land Most Readily Developed}

Much of south Dade County could be readily developed without additional drainage facilities; however, filling would be necessary in places to raise the surface to the floodcriteria elevations established by Dade County.

Areas in the Everglades and the marshes in the southeastern part of the area are not readily urbanized because of the high water table and periodic flooding. Efforts at the local, state, and federal levels to preserve wetlands probably will inhibit urbanization or other development of much of the wetland area of south Dade County. 


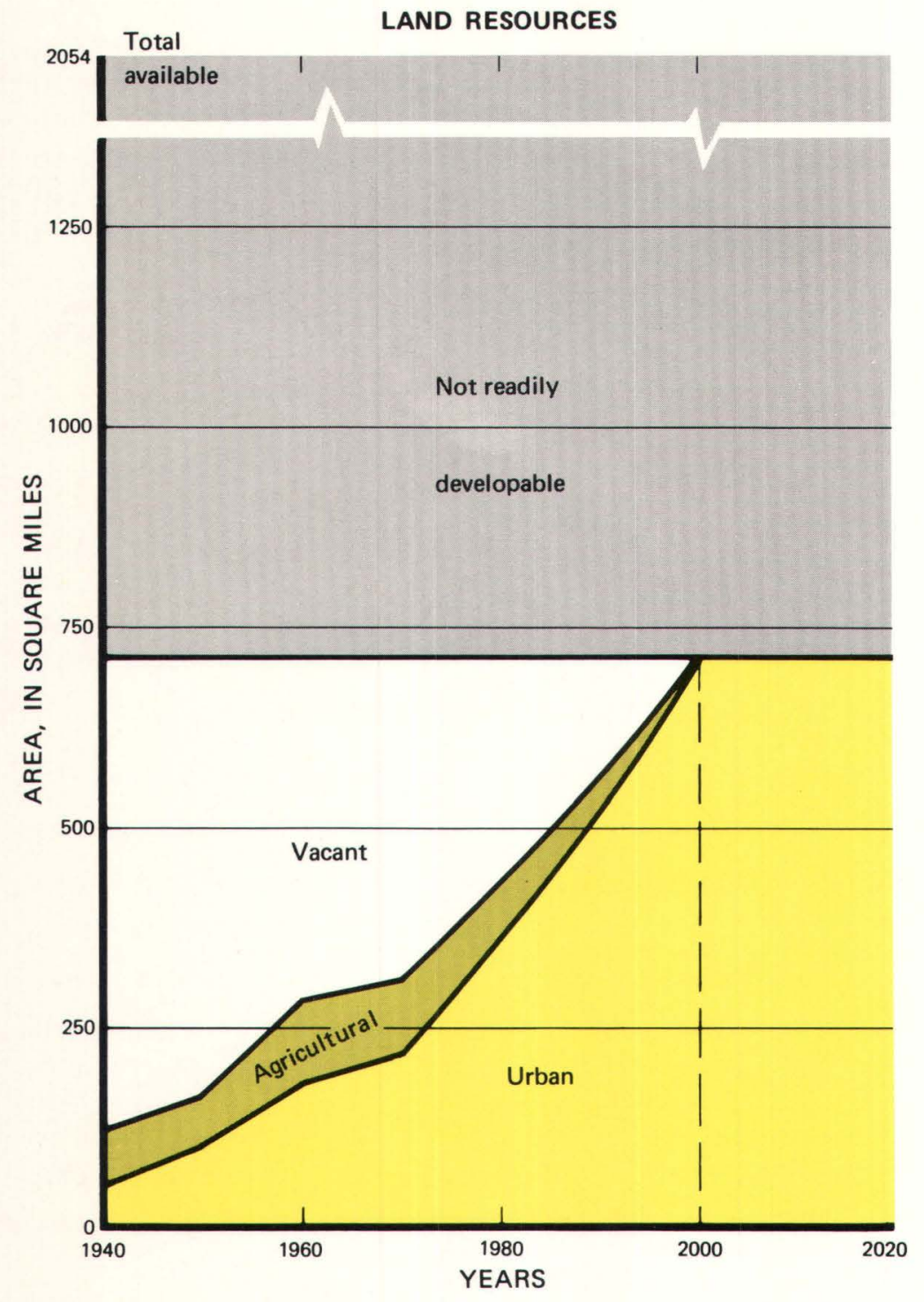

If population increases at the projected rate, all readily developable land should be urbanized by the year 2000.

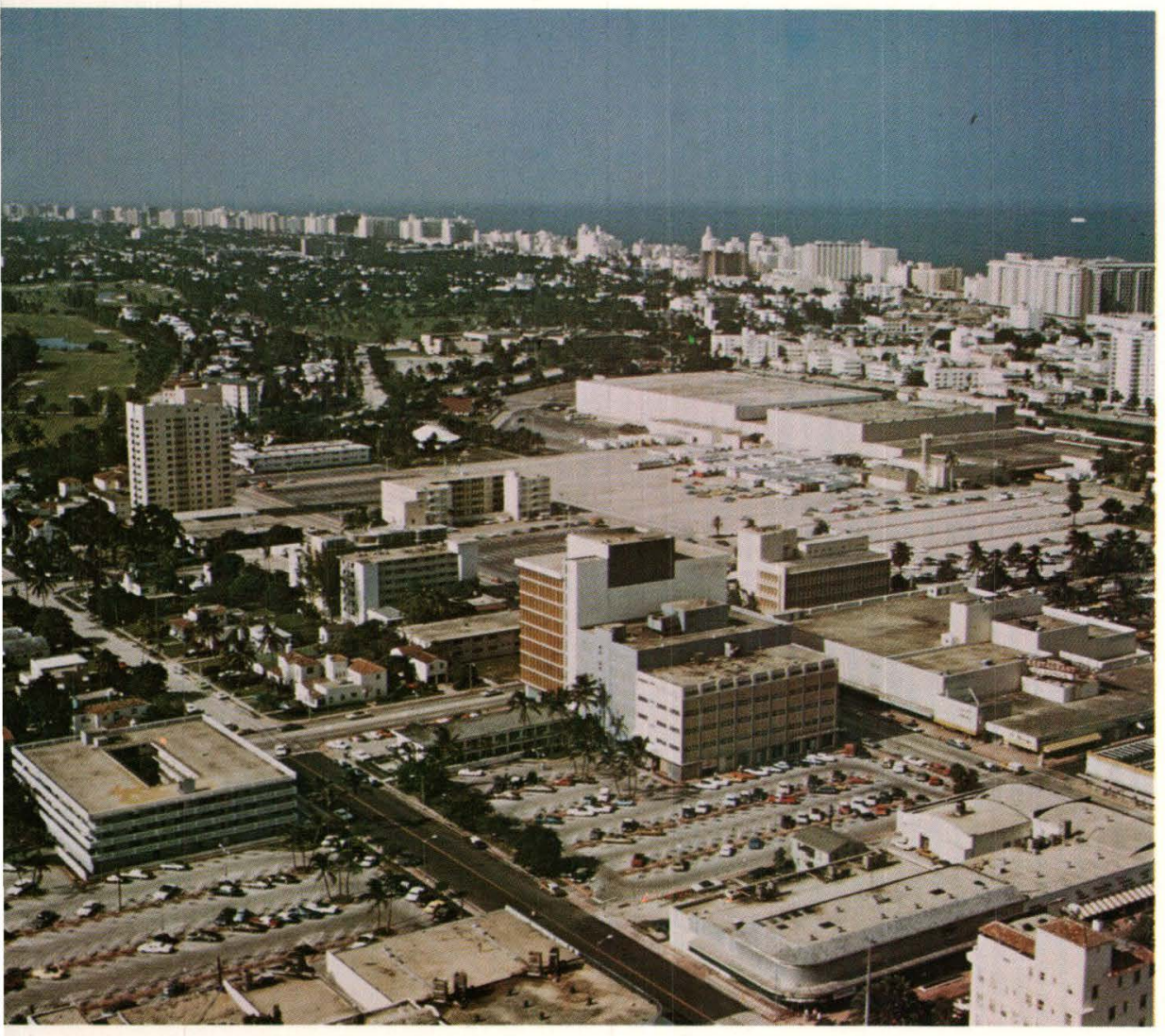

New, taller buildings erected in the last decade are increasing urban density in the already developed coastal areas.

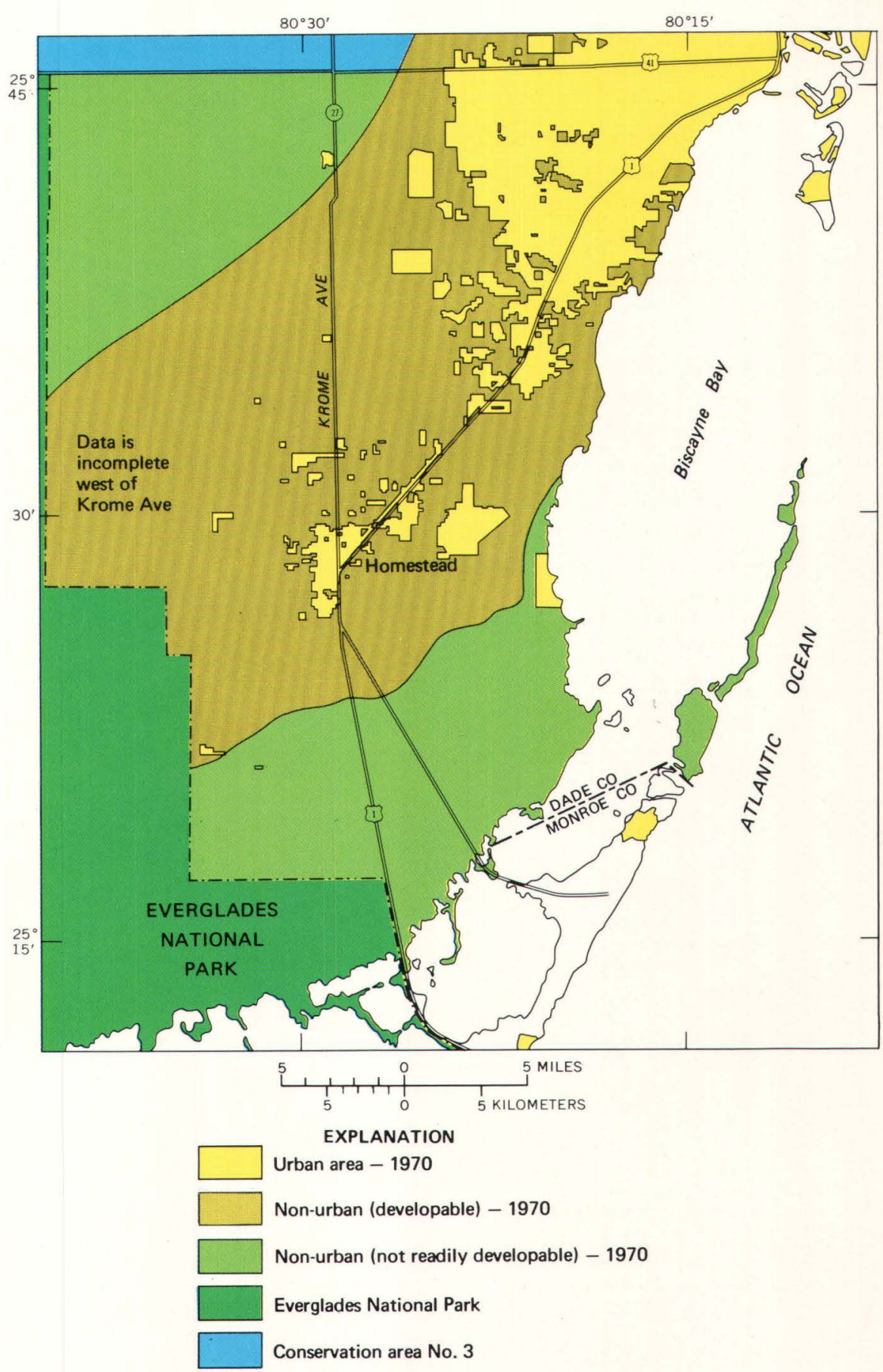

About one-third of the land most readily urbanized is already developed; much of the remaining two-thirds is used for agriculture.-5/ 


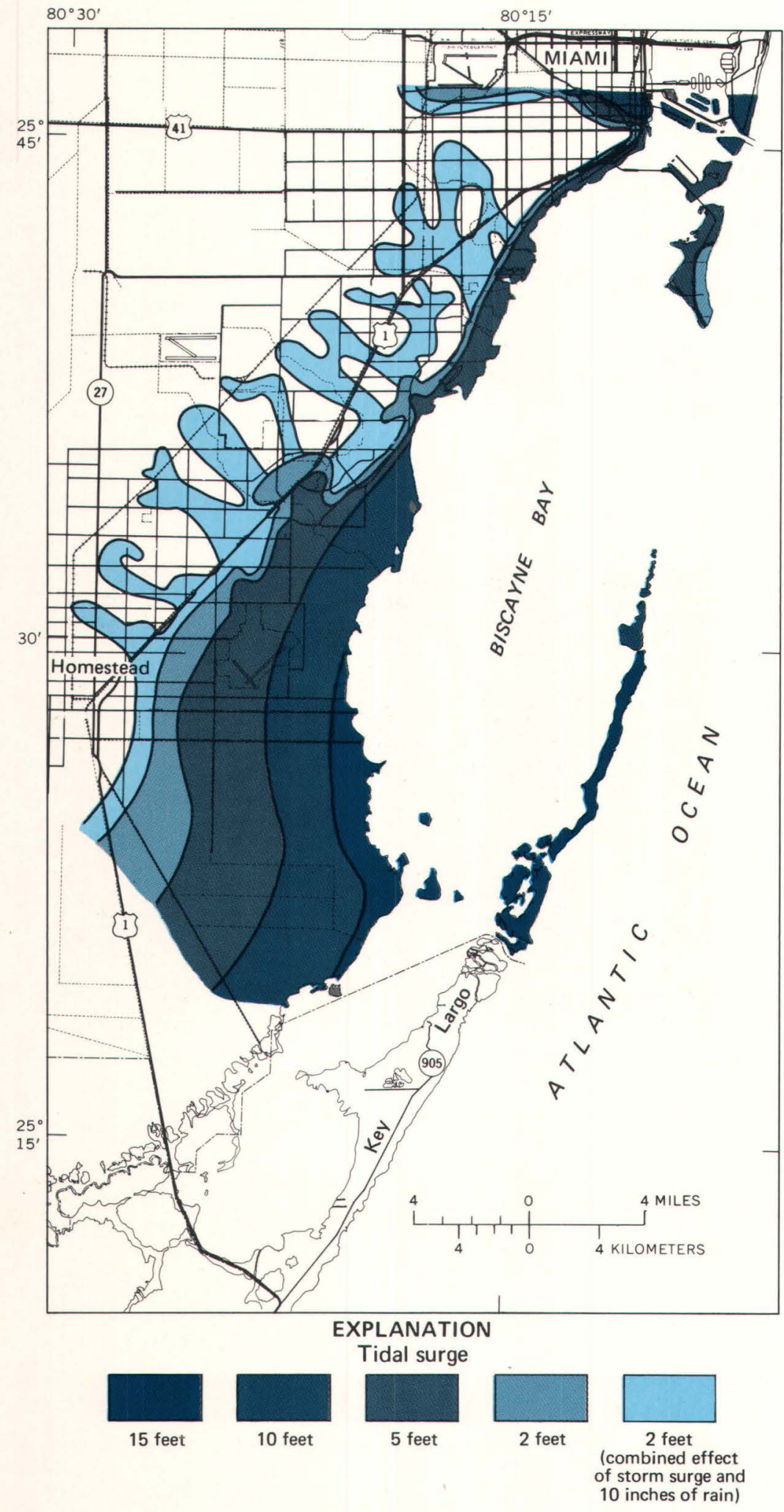

Hurricane tides can inundate much of the coastal area. Shown here are areas prone to such flooding as defined by the National Hurricane Center of the National Oceanic and Atmospheric Administration from historical records of hurricane tide elevations and topographic data. 2

point of hurricane entry from the ocean is generally the area of greatest damage. More than half of the 17 hurricanes since 1886 whose path crossed within 50 miles of the center of south Dade County approached from the ocean. The tidal surge and wave action developed by the intense winds and low barometric pressure may produce the greatest damage. A tidal surge of about 14 feet has been recorded in the south Dade area. Such a surge would inundate a large part of south Dade County. Metropolitan Dade County building codes incorporate design features which protect homes and businesses from destruction under hurricane-force winds. However, design features that would offer full protection under Great Hurricane force are not economically feasible. Heavy rainfall associated with hurricanes floods low-lying areas for several days. It is difficult to estimate the maximum total damage of a great hurricane; however, some estimates place the economic losses near the billion dollar mark. $\sqrt[3]{ }$

\section{Foundation Hazards}

Most of Dade County is underlain by limestone having solution cavities. A few general localities underlain by exceptionally large cavities are known but have not been mapped. The cavities significantly reduce bearing strength, so that high buildings generally require special foundations. Normal concrete footings, however, are usually sufficient to support two- or three-story buildings.

The cost of special foundations required in areas of unusually porous limestone is high. Nevertheless, poor foundation conditions have not inhibited construction.

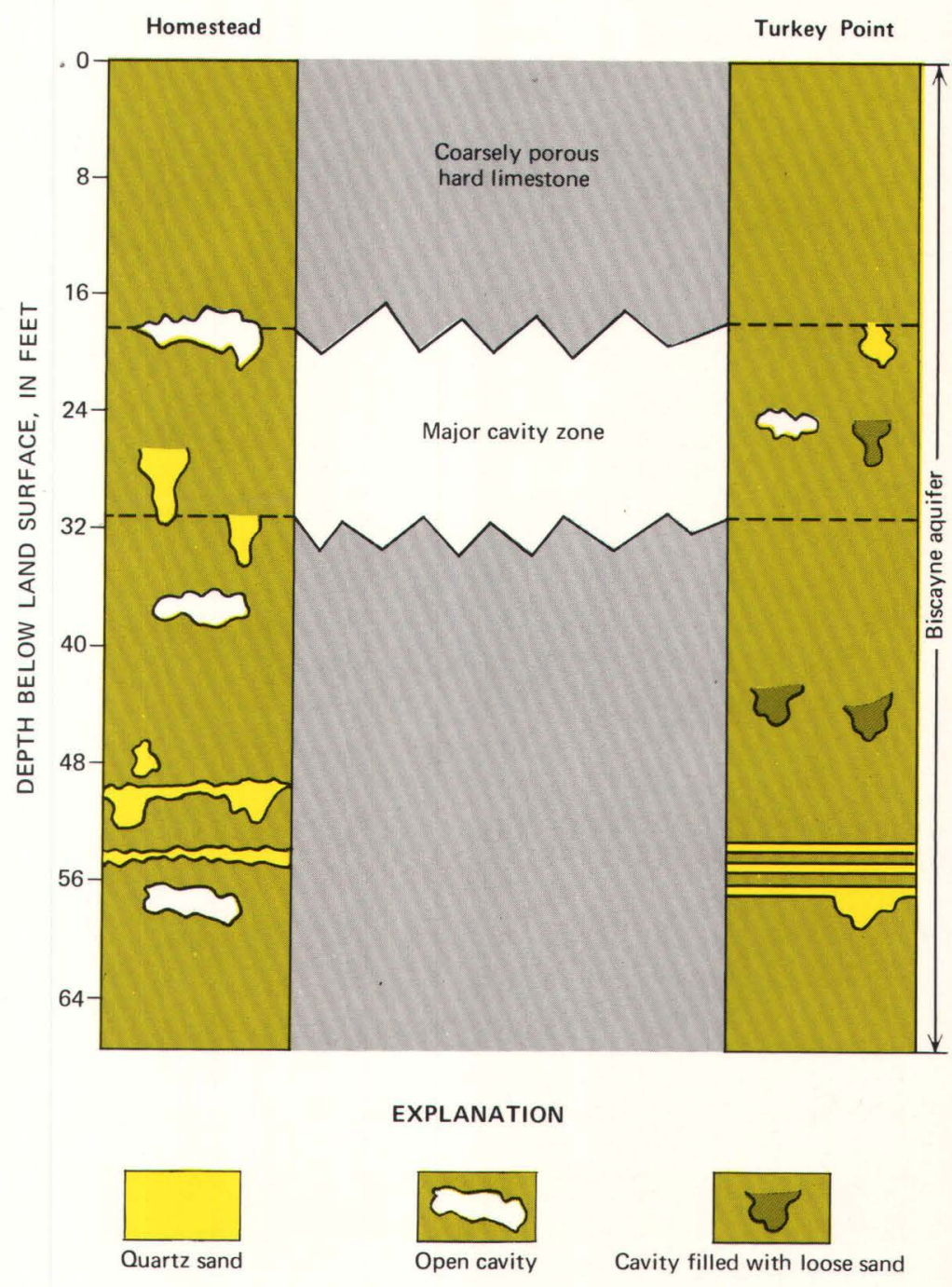

Distribution of cavities is shown schematically at two sites in the south Dade area. 


\section{MINERAL RESOURCES}

The most significant mineral commodity is limestone, found at or near land surface throughout the entire area, and used as base material for roads and airport runways, as construction aggregate, and in the manufacture of cement.

Small quantities of oyster shell were, in the past, dredged for use in road construction. However, restrictions against dredging have eliminated oyster shell as a mineral commodity. No oyster shell was dredged in 1971.

\section{Economic Aspects}

The principal product of the construction minerals industry is crushed limestone which varies in size depending upon end-use specifications. These specifications are largely governed by needs of the largest single purchaser, the Florida Department of Transportation. The two principal criteria are abrasion resistance and carbonate cement. Generally, stone to be used for aggregate must possess an abrasion resistance in which the material loss as determined by the Los Angeles Abrasion Test $1, \underline{2} /$ does not exceed 40 percent. Specifications require that the carbonate content of limestone must not be less than 70 percent, but may be as high as 95 percent, depending upon intended use. Most of the limestone meets both specifications.

Three percent of the total limestone output in 1971, crushed to one-fourth inch or less, is marketed locally as sand and gravel.

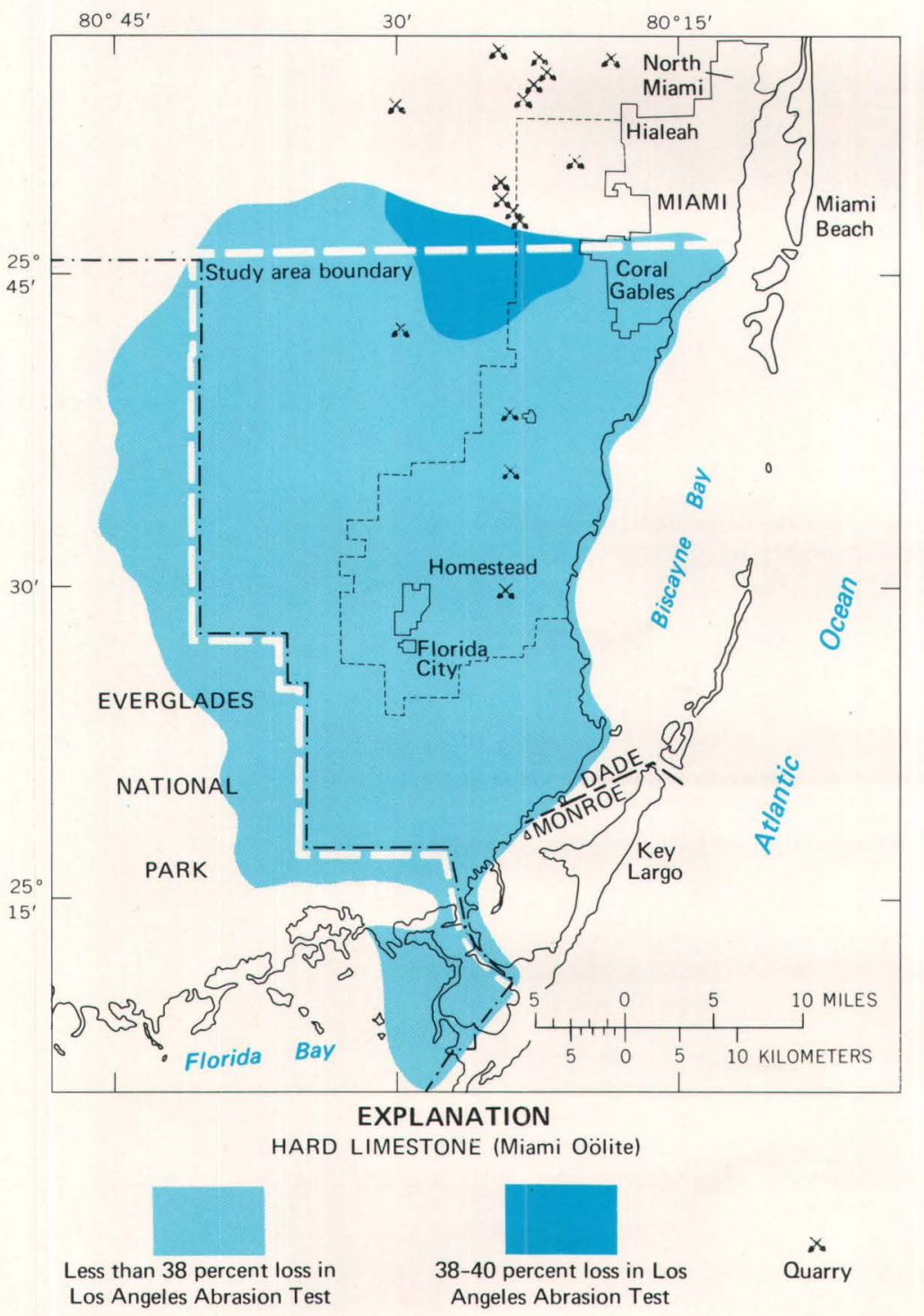

Large areas of south Dade County are underlain by limestone suitable for construction material.
Approximately 25 percent of the limestone quarried is used to make Portland cement, but local production does not meet demand and much is imported.

The total limestone resource is about 85 billion tons, of which 32 billion tons is available for quarrying under present conditions. The remainder is unavailable because of urban development.

Quarry operators seldom stockpile limestone and there are virtually no imports of crushed limestone. The combined production of limestone in Dade and adjacent Broward County increased from 10.9 million tons in 1962 to 21.3 million tons in 1971. By 1985, production of approximately 33.0 million tons is projected for the two counties. In 1962 and 1971, prices per ton, f.o.b. quarry, averaged $\$ 1.06$ and $\$ 1.42$, respectively; by 1985 , a price of $\$ 3$ per ton is expected.

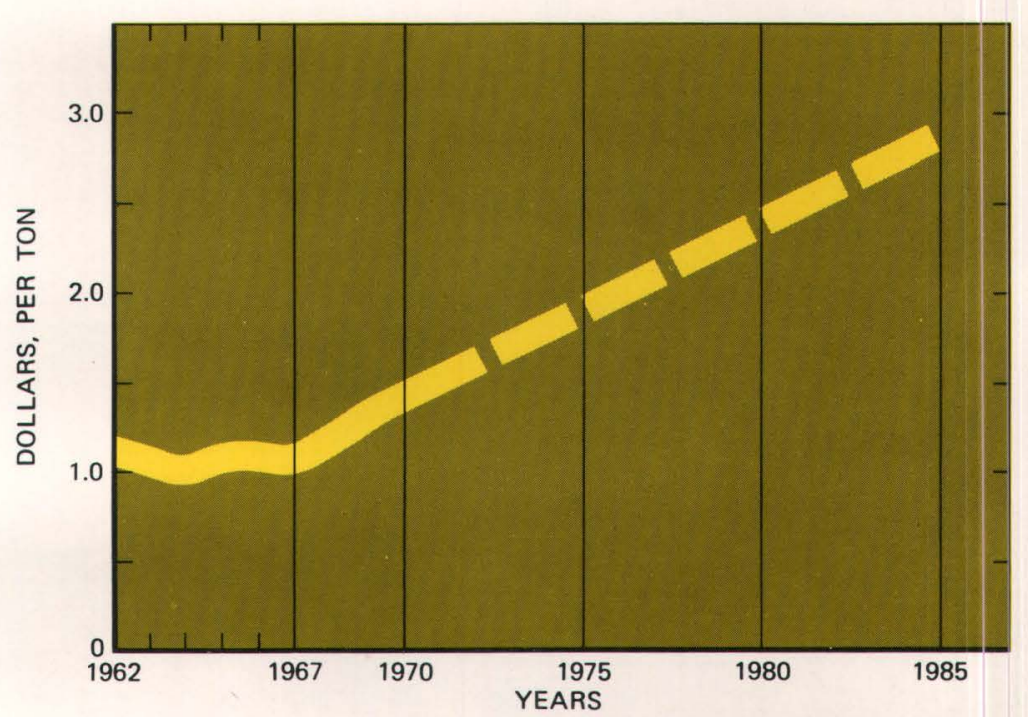

The upward trend of the price of crushed limestone is expected to continue.

\section{Quarrying Methods}

The average depth currently being quarried is 40 feet. Overburden is removed by bulldozer and placed around the perimeter of quarry sites. Holes are bored in the limestone and blasting agents are emplaced and detonated.

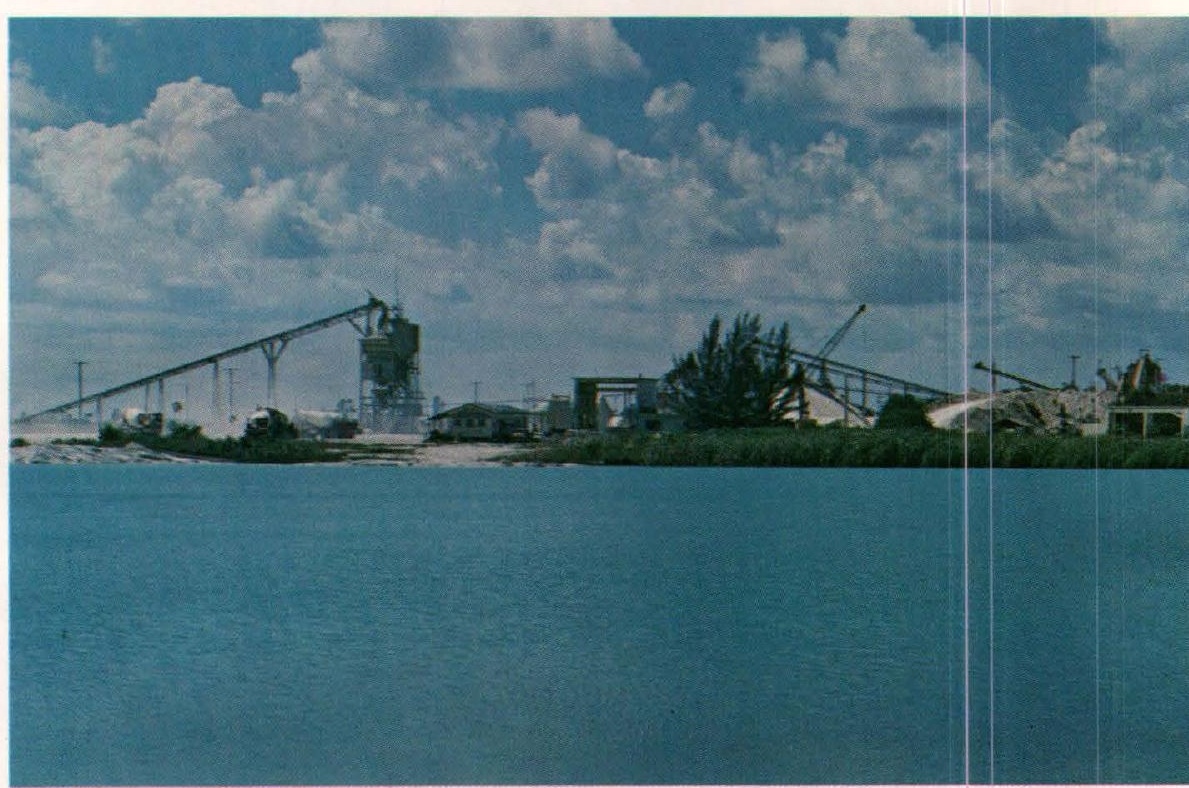

Quarrying limestone is the largest mineral industry in the area. 


\section{MANAGING THE WATER SYSTEM}

South Dade County is at the south end of a regional water system managed by the Central and Southern Florida Flood Control District. The District maintains and operates a system of levees, canals, control structures, pumping stations, and water storage areas by which the fresh water resources of Palm Beach, Broward, and Dade counties are managed. The levees impound water in Lake Okeechobee and in three conservation areas. They prevent sheet flow from the Everglades and Lake Okeechobee through agricultural and urban areas during the rainy season, June through October. Pumping stations at the edges of the conservation areas provide flood protection by pumping excess rainfall from the Everglades agricultural area and other flood-prone areas into Lake Okeechobee and the three conservation areas. Thus, the system not only protects against flooding, but also conserves water. Water is transferred from the conservation areas into Everglades National Park, or to coastal cities as needed.

Canals drain the urbanized strip along the coast. They also transfer water from Lake Okeechobee and the conservation areas to the Everglades agricultural area and to the east coast to replenish ground-water reservoirs near municipal well fields and to prevent sea-water intrusion. Flow in the canals is regulated by coastal control structures which are normally open or partly open during the rainy season. The structures are generally closed during dry seasons to prevent inland movement of salt water.

Water levels in southeast Florida rise during the rainy season until they reach annual highs, usually in October. Water levels are highest in Lake Okeechobee and the waterconservation areas and slope toward the coast. Flow in the canals is regulated so that ground-water levels in the urban and bordering farmlands are maintained at levels low enough to prevent flooding

Outflow from the canals varies from year to year depending upon rainfall. At the end of the rainy season, most coastal controls are closed to conserve water; thereafter, water levels normally decline to their annual lows, usually in May. On the average, 40 or more inches of the 60 inches of yearly rainfall is lost by evapotranspiration; the remainder is lost by canal discharge to the ocean, by ground-water seepage along the coast, and by withdrawals for municipal supplies and irrigation that are not returned to the hydrologic system. Although withdrawals represent the smallest part, they are ever-increasing.

Scheduled releases from one of the conservation areas are made during the year to sustain plants and animals in Everglades National Park. Late in the dry season water is also released from the conservation areas to the canals, as required, to maintain water levels near the coast and to sustain well fields. During much of the dry season, eastward flow in canals is maintained by water seeping under the levees of the water-conservation areas. However, water in the canals is not discharged to the ocean; rather it recharges the Biscayne aquifer along the coast. During prolonged drought some water can be transferred directly from Lake Okeechobee through the conservation areas to points of need along the coast. Usable storage in the lake is usually shared by municipalities, agricultural interests, and Everglades National Park. Getting this water to south Dade County, however, is difficult because of its location and lack of facilities to transport the water.

Sea-water intrusion has been and will continue to be a major threat to the water resources of southeast Florida, particularly those of south Dade County. The greatest

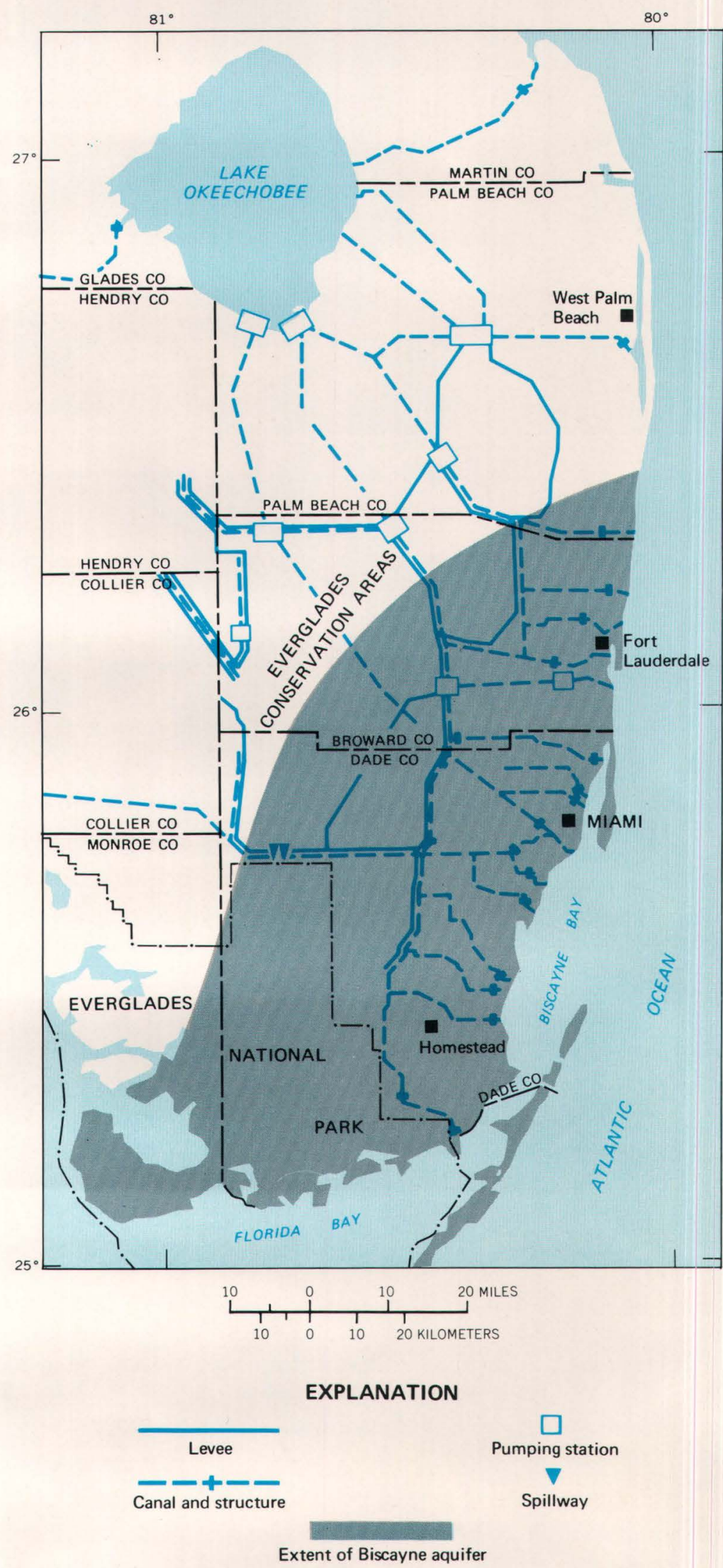

The water-management system of southeast Florida consists of levees, water-conservation areas, canals and control structures, and pumping stations. The system is operated to provide both surface drainage and recharge for the Biscayne aquifer. 1 - 
inland penetration occurred before 1946, when canal flows were not regulated by control structures. Intrusion then was the result of overdrainage by canals rather than pumping 2 . Water management practices of the Central and Southern Florida Flood Control Project, beginning in 1952, have stabilized the sea-water intrusion. However, during the drought of 1970-71, ground-water levels declined abnormally and in parts of south Dade County salt water temporarily advanced more than half a mile inland from its normal position 3 ? Preliminary studies indicate that a drought of this magnitude may be expected only once in several centuries.

The chief water problems presently facing water managers are: (1) satisfying the water demands of an ever-increasing population while still retaining sufficient water in the system to meet the needs of the aquatic environments; and (2) upgrading and maintaining the water quality in the water-storage areas, the canals, and the aquifer. Reducing discharge of surplus water to the ocean can moderate water shortages in south Dade County and the National Park.

All municipal water systems from Boca Raton southward are supplied from the productive Biscayne aquifer, which extends from the south tip of Florida northward into Palm Beach County. The aquifer is wedge-shaped, thick near the coast, and thin along the western and central parts of the Everglades. In coastal Miami it extends to a depth of about 120 feet, and in coastal south Dade County to about 80 feet. The aquifer is very productive in south and central Dade County. It contains fresh water, except along the coast where it is intruded by sea water.
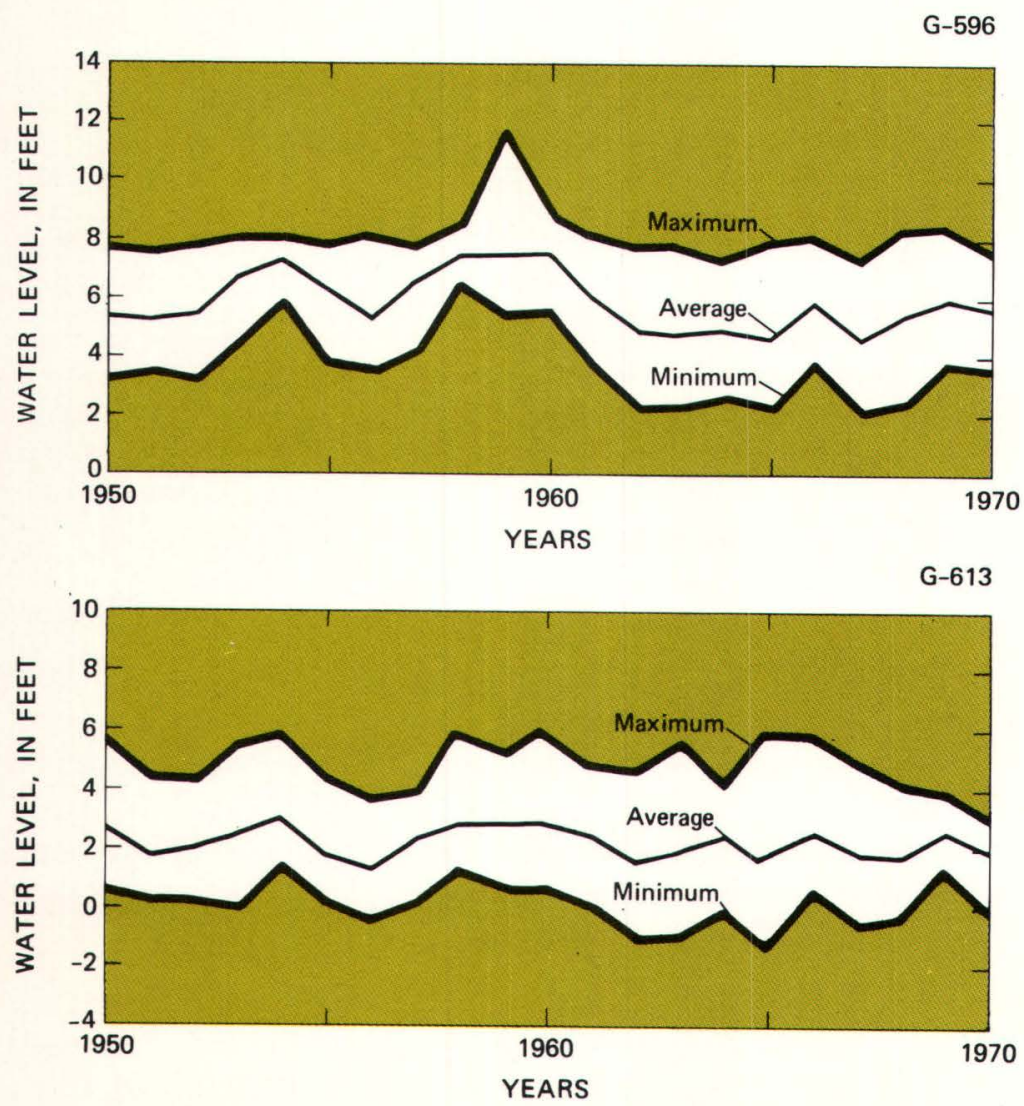

The extensive canal network in south Dade County, constructed after 1960, lowered peak water levels to reduce flooding. The effect of the network was a general downward displacement of water levels. Shown here are hydrographs of ground-water levels for 2 wells in the area.

\section{Water-Related Problems}

\section{Flood Protection}

Residential clusters suburban to Miami began to appear in the Snapper Creek Canal area in the mid 1950's. Before then only small scattered areas, primarily along the high parts of the Coastal Ridge, between Miami and Homestead, were occupied by housing. Most of the remaining area was agricultural. Flooding in most of south Dade County during rainy seasons tended to retard urban development. Flooding and heavy damage south of the Snapper Creek Canal associated with Hurricane Donna in September 1960, however, provided the impetus for extension of the drainage canal network into south Dade County. The network, completed in 1967, resulted in rapid urban development since the mid 1960's.
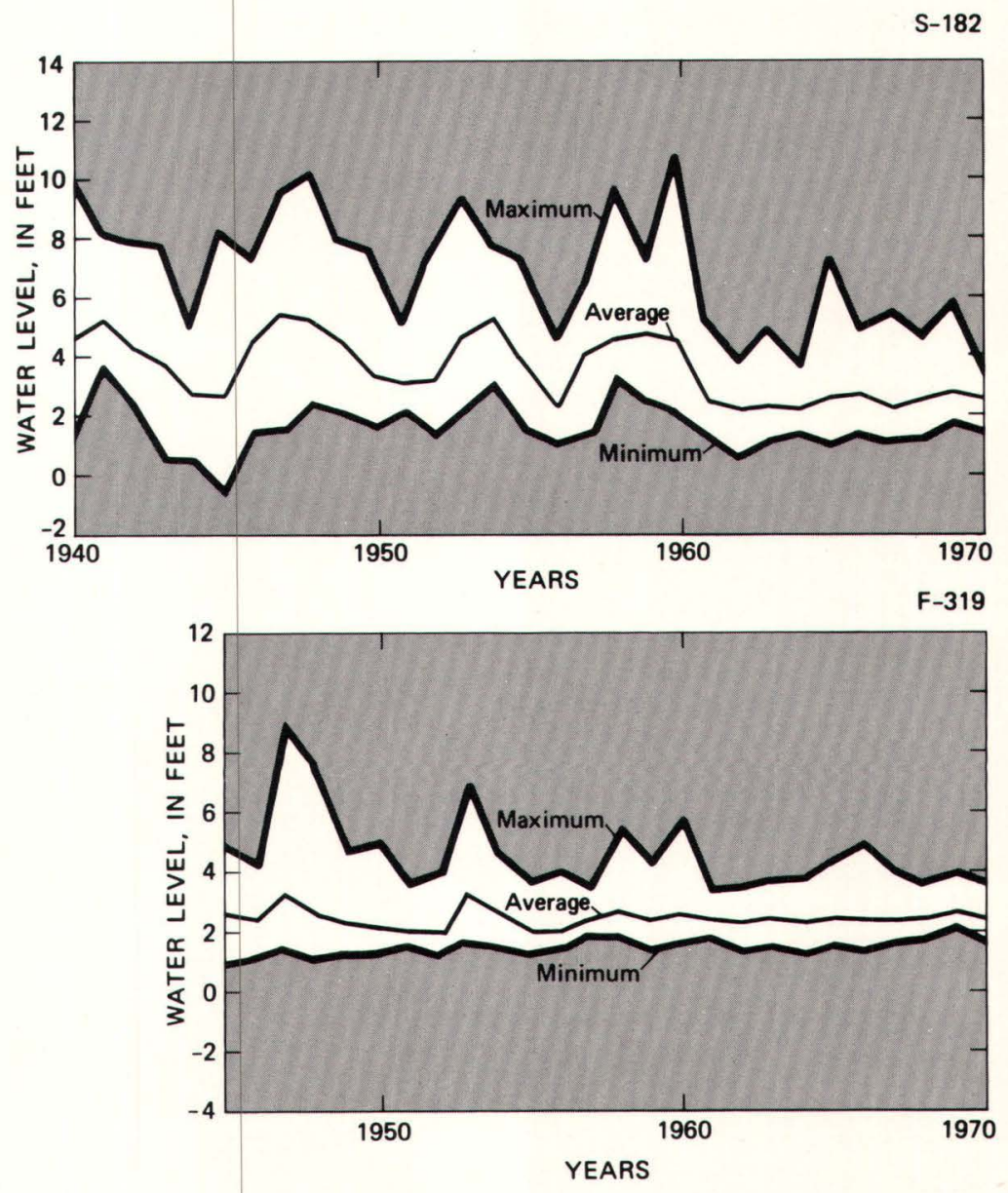

In some coastal areas annual minimum water levels were raised as a result of the canal network. Shown here are water levels for 2 wells near the coast. 3

\section{Low-Water Levels}

The canals have lowered water levels in the interior of south Dade County sufficiently to prevent flooding; but the range in annual water-level fluctuations has increased. Along the coast, maximum levels were lowered 2 to 4 feet, but minimum levels are higher than in pre-canal times.

The rise in low-water levels near the coast (wells F-319, S-182)helps retard sea-water intrusion. Water levels are lowest in the south part of the area where they have declined below sea level in 8 of the 10 years between 1961 and 1970 4 


\section{MANAGING THE WATER SYSTEM}

Water levels in south Dade County are low each dry season. When they decline below sea level for a long time, plants and animals in Everglades National Park suffer from lack of water. Such a condition existed in the spring of 1971 (see map). At that time, the water level in the south was lower than 1.5 feet below sea level so that hydraulic gradient there was northward and inland, from Florida Bay and Biscayne Bay toward the south part of the Park and Homestead. As the southernmost water-conservation area was nearly dry, the only fresh-water replenishment was ground water moving eastward and southward from that conservation area. Fortunately, this low-water condition was temporary. After the rains in early June 1971, water levels began to rise and the normal seaward gradient was restored.

Low-water conditions exist each year. Consequently, the threat of sea-water intrusion will recur with equal or greater severity as water demands increase, unless additional water is supplied to south Dade County.

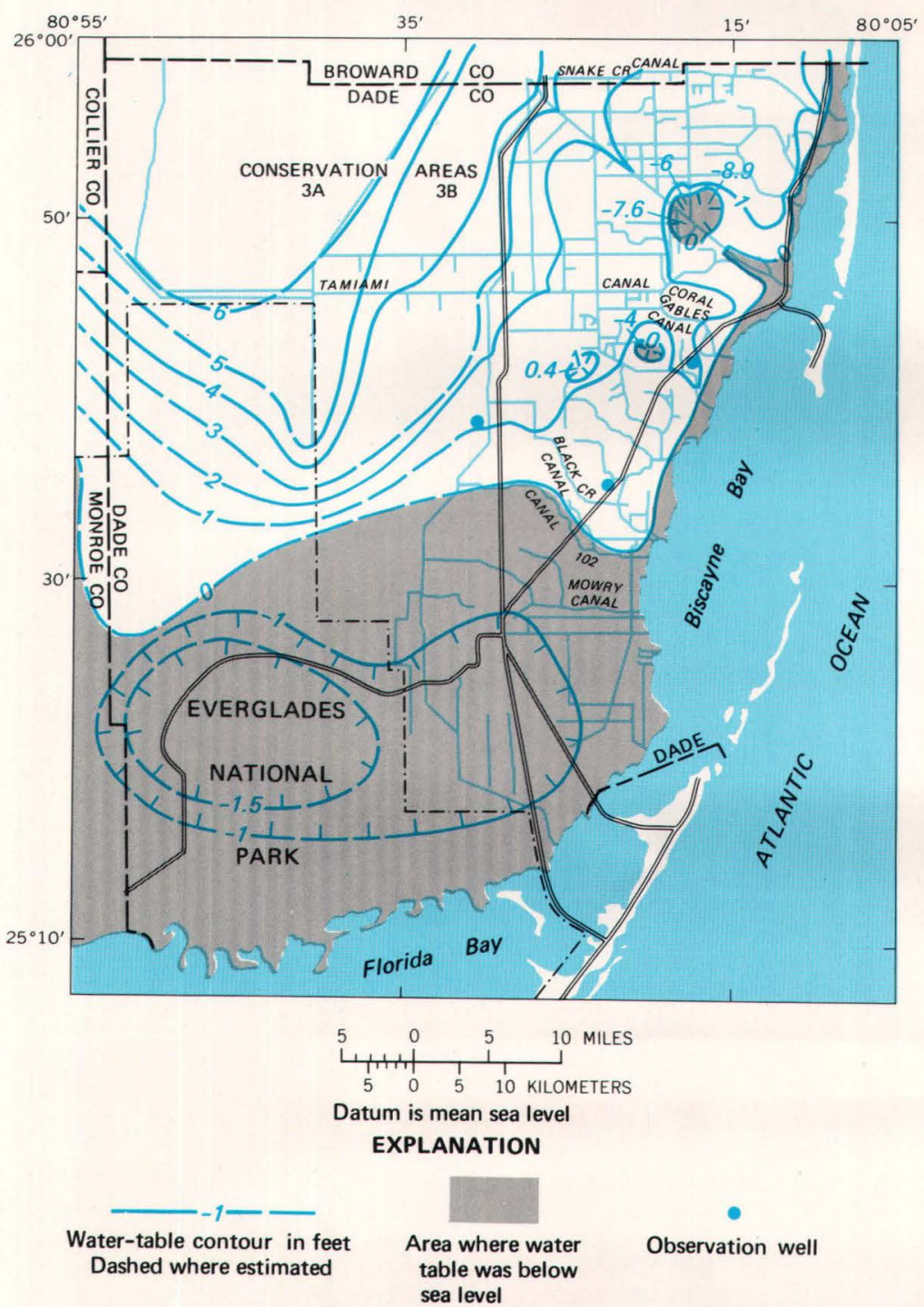

Near the end of the prolonged drought of 1970-71, water levels were below sea level throughout the south half of the area. Salt water moved inland and plants and animals in Everglades National Park were severely stressed. 3 /

\section{Sea-Water Intrusion}

Sea water has intruded the Biscayne aquifer along the coast from less than half a mile inland to about 8 miles inland (see map). Salty water in the canals and in the aquifer

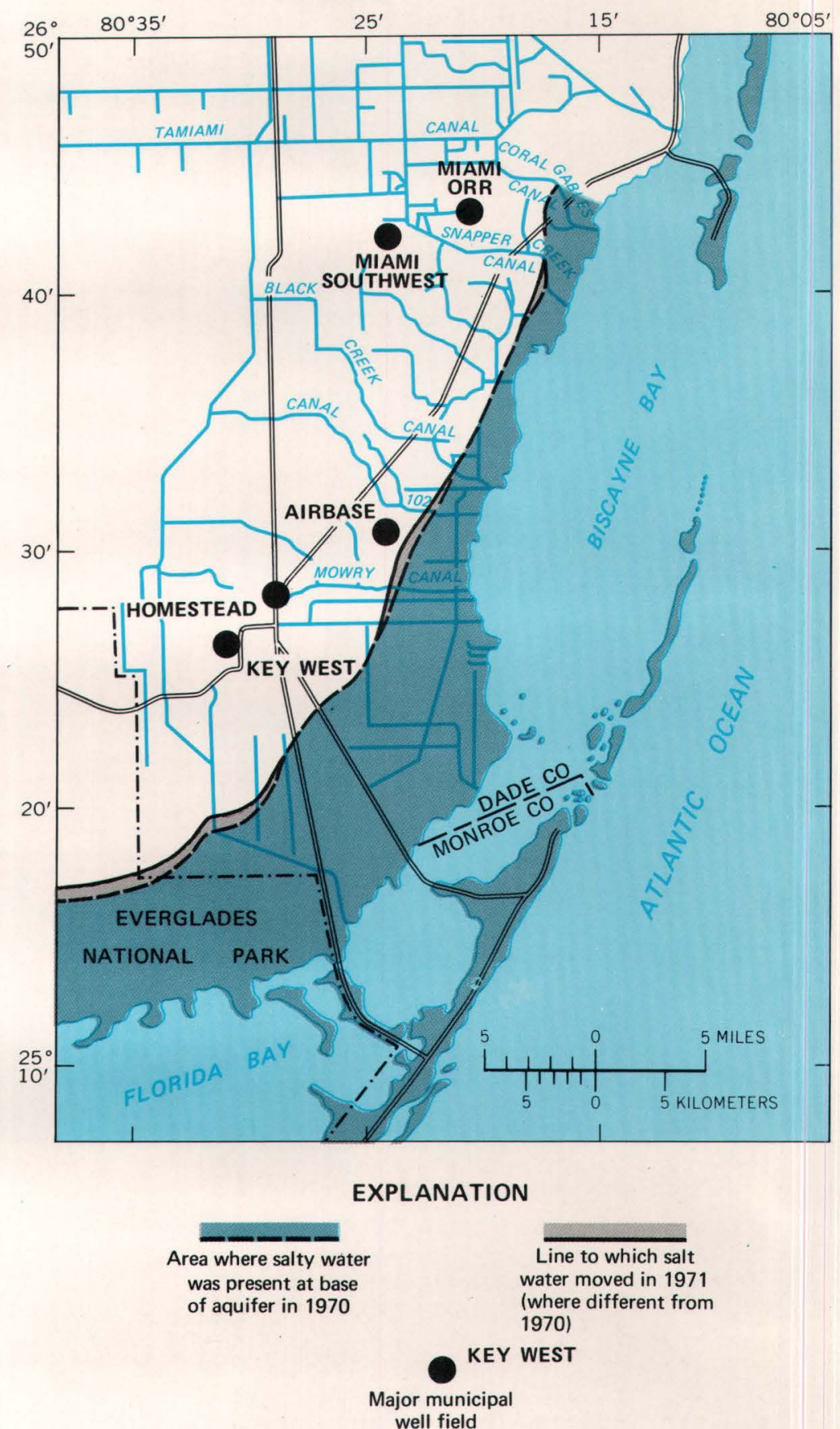

Sea-water intrusion is a problem in coastal south Dade County. It can be minimized through strict water-conservation measures and by increasing fresh-water replenishment from the water-storage system.

moves in reponse to seasonal rainfall. During the rainy season, increased runoff dilutes sea water in the tidal reaches of canals; at the same time, rising ground-water levels throughout the area push the salty ground water downward and seaward in the coastal part of the aquifer.

During the dry season, runoff to the ocean decreases or stops, and sea water moves upstream toward the coastal control structures. As water levels decline, sea water moves inland and upward in the coastal parts of the aquifer. The dense salt water moves inland along the lower part of the aquifer and the fresh water moves seaward in the upper part of the aquifer (see facing page) 5 ? Salt water has intruded a wide coastal zone in the south because water levels there during each dry season are lower than they are in the remainder of the area; also the land is low, only 1 to 4 feet above sea level, and is subject to periodic tidal flooding.

At the end of the drought of 1970-71, salty water in the aquifer had moved more than half a mile inland from its 1970 position in the Canal 111 area, and in the area 
between Canal 102 and Mowry Canal. As the drought intensified, salty ground water in these two areas moved inland and upward and seeped into the controlled reaches of the canals. The contaminated canal water then moved inland and seeped laterally and downward into the aquifer. The seepage was particularly critical in the Canal 102Mowry Canal area where pumping at Homestead Air Force Base accelerated inland movement. As a temporary precaution, new supply wells were drilled farther inland to minimize salt-water movement and to prevent long-term damage to the permanent well field. The inland movement of salt water in the Snapper Creek Canal area was not as severe because water levels there were maintained above sea level throughout the drought.

Further changes in the salt-water front in the Biscayne aquifer can be expected as a result of the drainage. However, movement of sufficient water to the south during dry season in accordance with existing plans, will control further intrusion of sea water. Largest increases in user demands in the area will be from the Key West (Navy) and Homestead systems. However, supplying these increases will require that supplemental water for local recharge of the Biscayne aquifer be made available 6 !

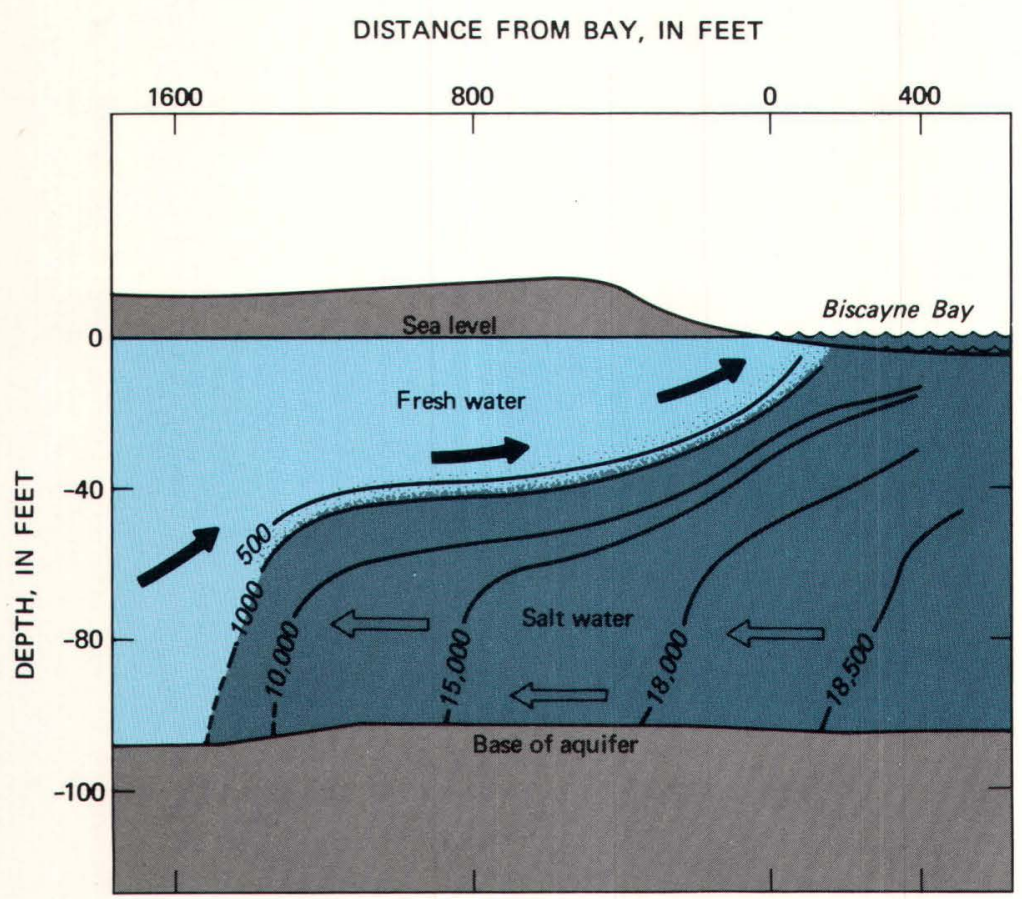

The pattern of salt-water intrusion in the Biscayne aquifer is shown schematically.

\section{Municipal Pumpage}

The Orr-Southwest well-field complex, the largest in south Dade County, furnishes water to much of the city of Miami as well as to Coral Gables, West Miami, South Miami, Key Biscayne, and adjacent unincorporated areas. It will eventually serve the northern third of south Dade County. The combined well field includes 10 wells of $70 \mathrm{mgd}$ capacity in the Orr section, and 10 wells of 100 mgd in the Southwest section. The wells average 90 feet deep.

Because of the high permeability of the Biscayne aquifer and the good hydraulic connection between the aquifer and Snapper Creek Canal, a major part of the water pumped by the city of Miami well field is derived by infiltration from the canal (see map).
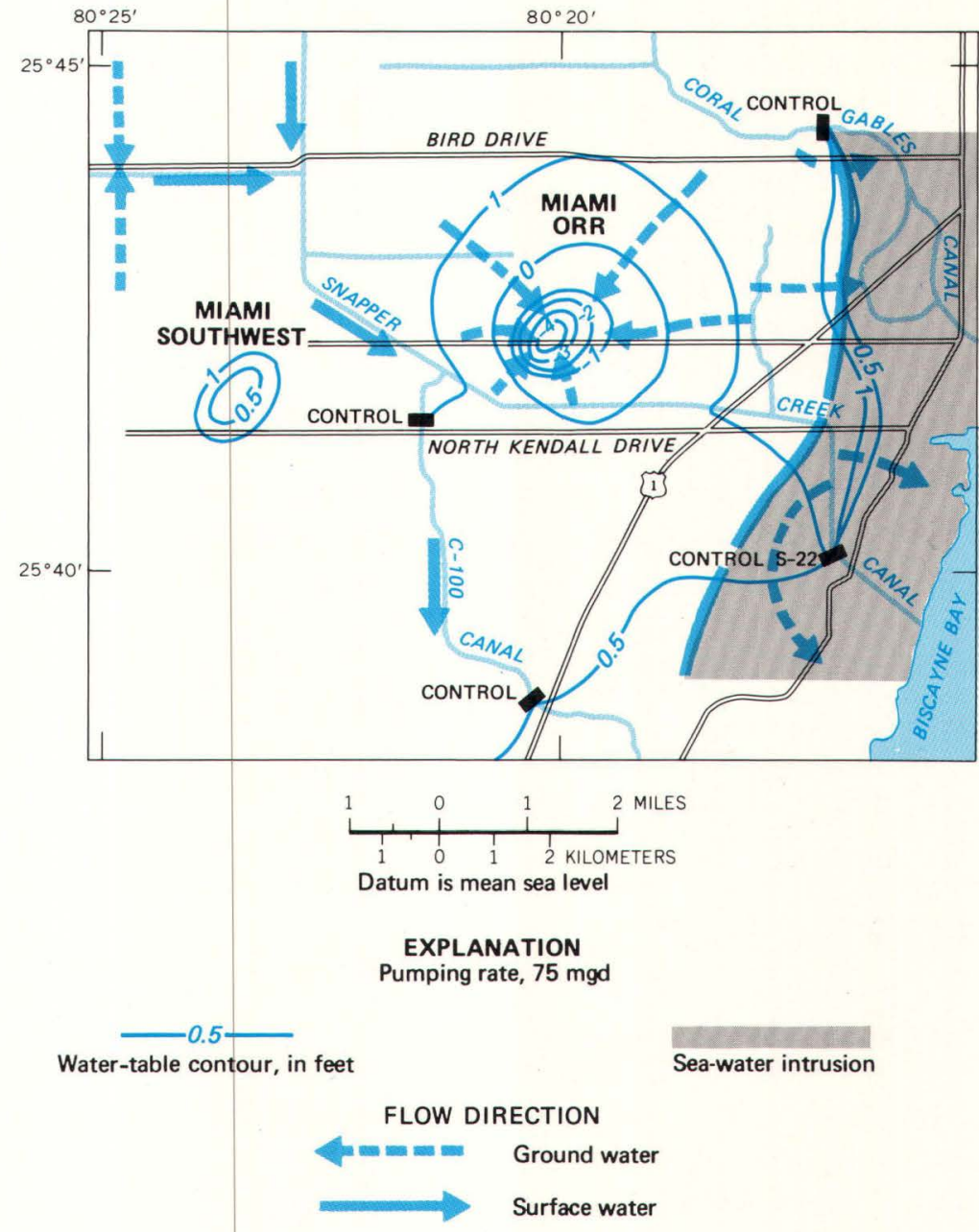

The largest municipal well field in south Dade County, the Orr-Southwest field of the city of Miami, is recharged primarily by seepage from the controlled reach of Snapper Creek Canal. The well field is protected from sea-water intrusion by the ability of the canal to maintain relatively high water levels. 3 /

New well fields probably will be needed to serve the growing population. These fields are best located far enough inland to negate the threat of sea-water intrusion. Pumping of well fields in selected intercanal areas would lower water levels and reduce evapotranspiration. Waterlevel drawndowns due to pumping would finally be stabilized by inducing infiltration from distant canals $\stackrel{7}{?}$

\section{Water-Management Alternatives}

Projected growth in south Dade County will further stress the water resources. Implementation plans to increase the capacity of the Levee 31 Canal will facilitate movement of water from the water storage areas to south Dade County. However, increasing the capacity of the delivery system will be of little consequence if water is not available for transport.

Water needs for a growing population can be at least partly satisfied by conserving for use during dry season excess water that otherwise would flow to the ocean during the rainy season. However, conserving this water could change the amount and distribution of water in the aquatic environs with resultant effects on plants and animals. 


\section{MANAGING THE WATER SYSTEM}

\section{Backpumping Storm Water}

One method for alleviating water shortages during dry periods is to pump back into Conservation Area 3 storm water that would otherwise flow to the ocean. Pumping stations could be located along Levee 30 at the north county boundary, at the Tamiami Canal, and at an intermediate site 8 - Storm water could be backpumped from an area of about 175 square miles east of Levee 30 in the north half of the county. A network of canals dissecting the area would be necessary to facilitate movement of water to the pumping stations. Pumping would be frequent during rainy seasons and sporadic during dry seasons. The increased water storage in Conservation Area 3 would permit increased regulated releases of surface water to canals and additional seepage to the canals from Conservation Area 3. This in turn would maintain high water levels at the coast for longer periods which would retard seawater intrusion and furnish long-term recharge for municipal well fields. Water thus recovered would help minimize biologic changes in Everglades National Park if the water quality is not impaired.

During the past 12 years, seaward flow from canals in Dade County north of Snapper Creek Canal was about $1,200 \mathrm{cfs}$ (cubic feet per second). In the lowest year, it averaged about $600 \mathrm{cfs}$. If only half of this minimum flow were backpumped, an additional $200 \mathrm{mgd}$ could be recovered for use. Based upon present water consumption rates in Dade County, $9 /$ the hydrologic system within Dade County augmented by backpumping could sustain a total county population of 2.5 million, without further stress
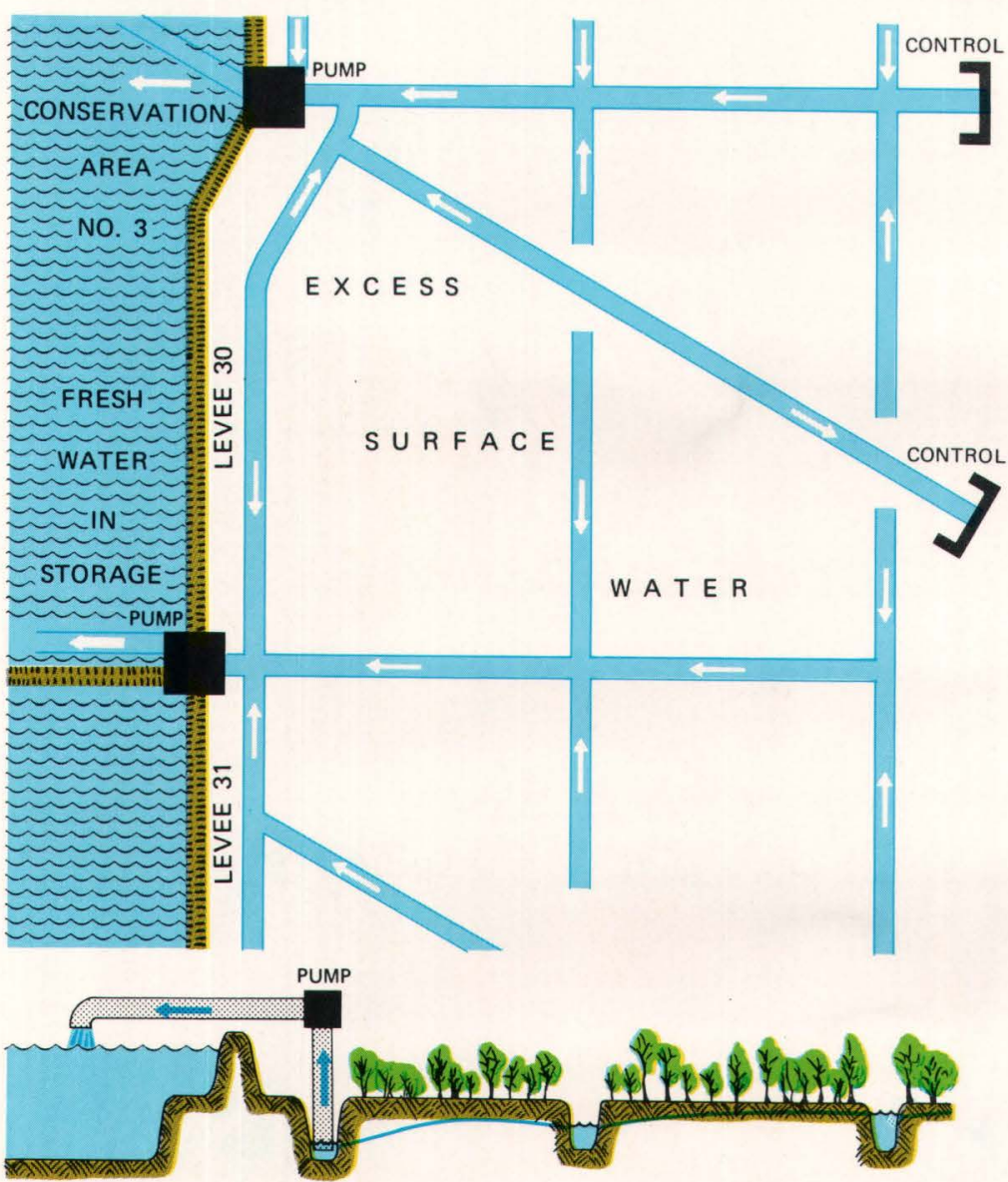

One way to alleviate water shortages during droughts is to backpump to the water-conservation areas part of the excess storm water currently being discharged to the ocean during rainy seasons. on the water resources. The water backpumped, however, must be of acceptable quality. Excessive nutrients, pesticides, or toxic metals in the water could change or adversely affect aquatic life in Conservation Area 3 and Everglades National Park.

Backpumping would decrease the flow of fresh water into north Biscayne Bay which in turn would alter the seasonal salinity of the water. As this part of the bay has been degraded by waste discharge and dredging, $\underline{10}$ the changes in salinity may not be important. Backpumping would reduce flooding over a large area that is now undeveloped and encourage agricultural and urban development. Without adequate pollution controls this development could further degrade the quality of water that would be backpumped to Conservation Area 3.

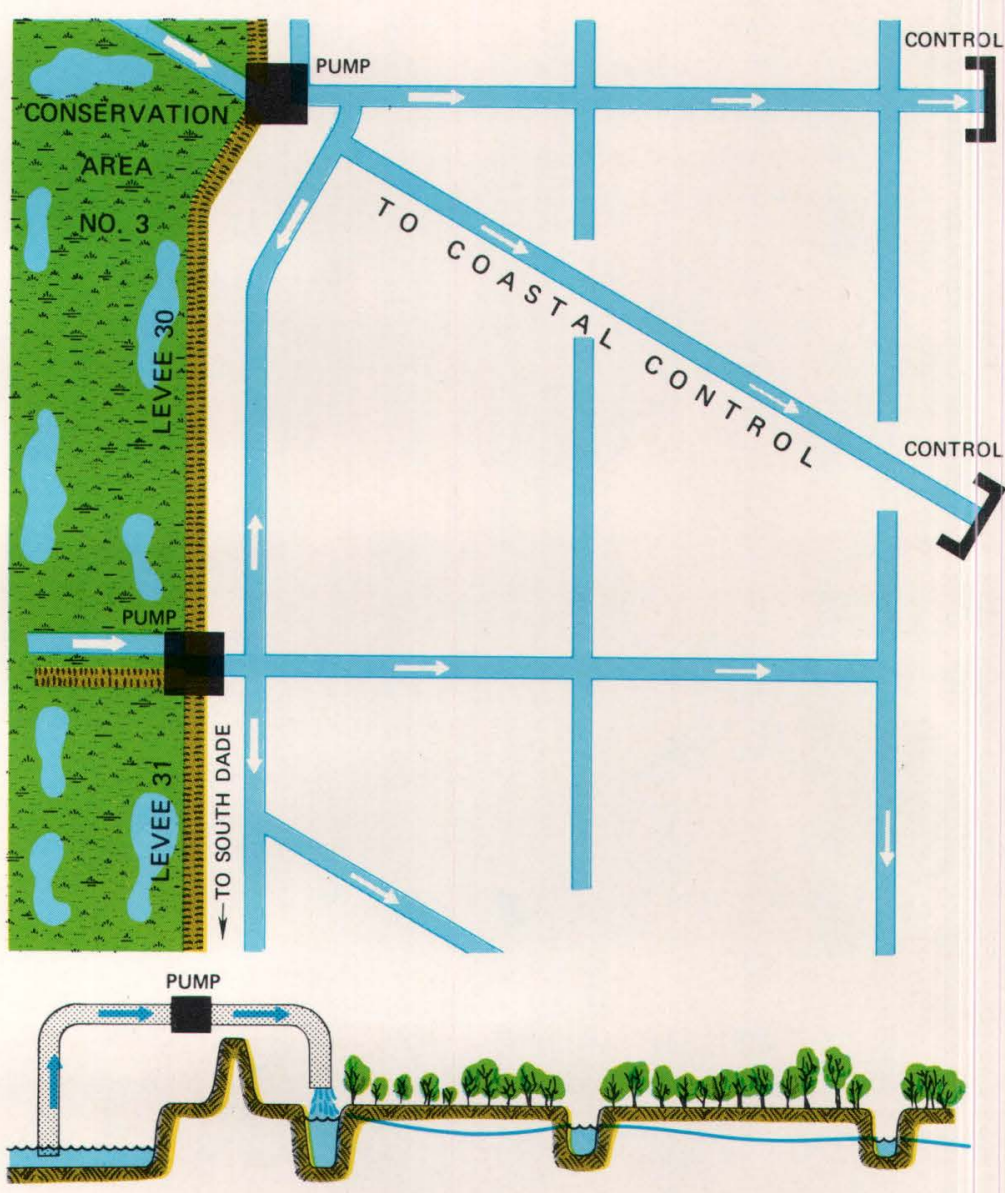

Another alternative is forward pumping which involves the eastward pumping from surface and underground storage in the conservation areas into the urban canal system to augment coastal water supplies.

\section{Forward Pumping}

Forward (seaward) pumping of water from surface and underground storage in Conservation Area 3 could augment water supplies in coastal areas during periods of prolonged droughts. The pumped water would be distributed to the canals which furnish recharge to major well fields and to the Levee 31 Canal for delivery to south Dade County. A network of canals would be required in Conservation Area 3 to allow water to move to the pump intakes. Equipment used for backpumping could also be used for forward pumping. 
Forward pumping would salvage water that is ordinarily lost by evapotranspiration in Conservation Area 39 . However, prolonged pumping would further reduce the water in storage and could result in changes in the biota in Conservation Area 3 and the interior of Everglades National Park. On the other hand, forward pumping to south Dade County would benefit biologic communities in the southeast panhandle of the Everglades National Park.

To sustain proper water levels at coastal control structures in the selected canals, the quantity of water to be pumped forward would have to equal the quantity of water lost by seepage at the coastal controls (about $50 \mathrm{cfs}$ per canal) plus the quantity diverted by well field withdrawals 4 . The lowering of water levels in Conservation Area 3 would be seasonal, as water lost from Conservation Area 3 by forward pumping would be replenished during the rainy season.

\section{Inland Control Structures in Canals}

Secondary control structures along the inland reaches of canals reduce fresh-water losses by maintaining higher water levels in the interior areas and preventing overdrainage of ground water 4 . The structures give flexibility to management operations because coastal urban areas can be protected from flooding while inland drainage can be minimized. All primary canals in south Dade County south of Snapper Creek Canal are equipped with such inland control structures.

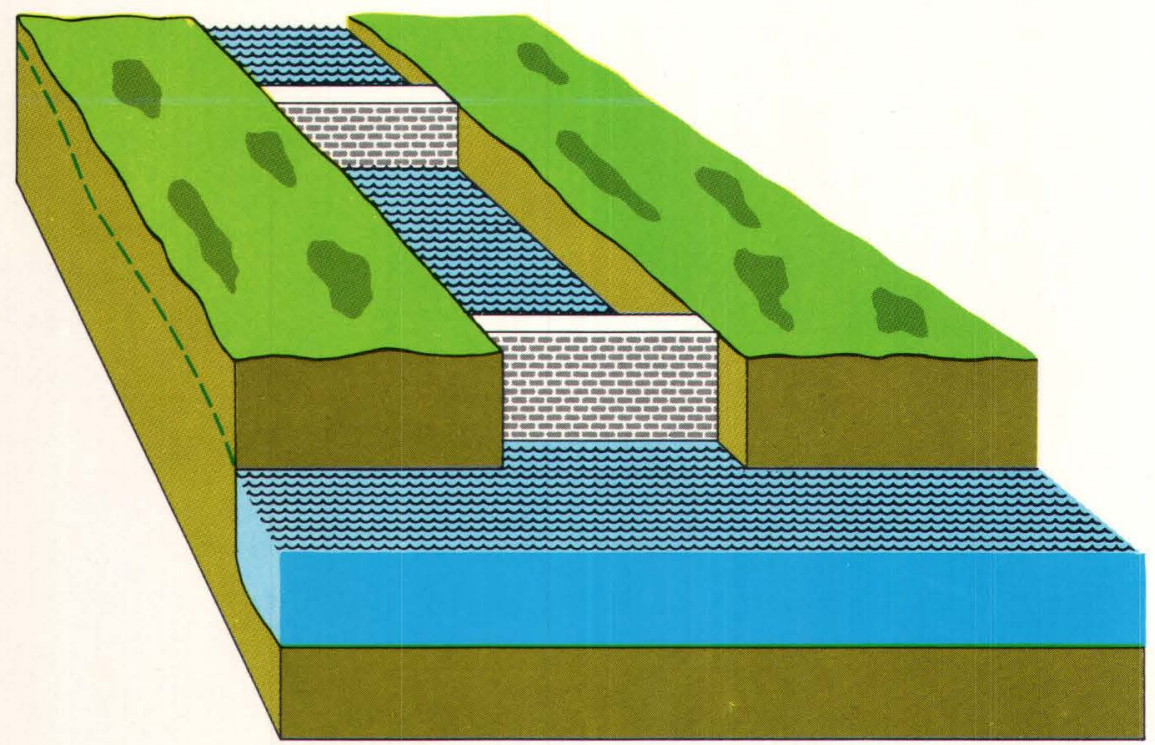

Water levels can be stepped up from the coast to the water storage areas by inland control structures in canals.

Inland control structures in south Dade canals are less effective in reducing fresh-water losses to the ocean than those in other areas because of the higher permeability of the Biscayne aquifer there. The high permeability allows more water to seep around the structures and out of the controlled reaches of canal. Despite this high permeability, additional structures on Snapper Creek and Black Creek Canals would help delay runoff and conserve fresh water.

Reducing fresh-water discharge to the ocean would not only decrease the rate at which water levels decline but also would reduce the period that water levels in the south part of the area and Everglades National Park are below sea level. High water levels may make it more difficult to urbanize some interior areas but would benefit aquatic environments. Water conserved through operation of inland control structures could complement the backpumping plan for water conservation.

Further saving of water in the controlled reaches of the canals might be accomplished by grouting the limestone at the control structures or by lining the canals upstream from the structures to reduce seepage.

\section{Coastal Urbanization}

Much of the coastal area in south Dade County is less than 5 feet above sea level. Except for a coastal fringe of mangrove and salt marsh, the land is used for agriculture. Farming normally begins late in the rainy season, and extends well into the dry season. During this growing season control structures are regulated to maintain low water levels necessary for agricultural production. In some years fresh water is discharged to the ocean for several weeks in the dry season, a practice not compatible with water conservation 4 !
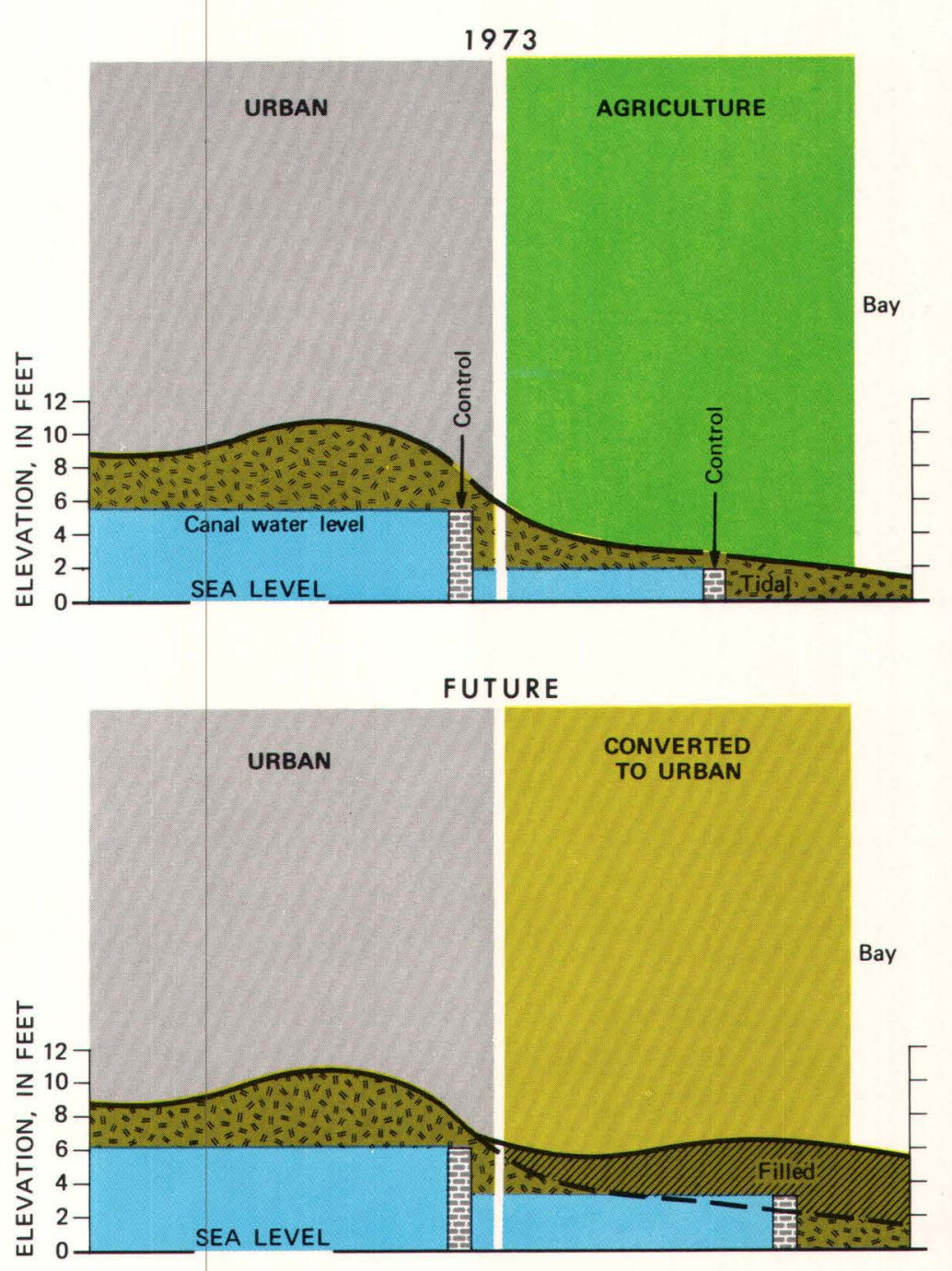

Urbanization of coastal areas requires filling to elevations above tidal flood levels.

Land-use and population projections indicate that agricultural areas in south Dade will gradually be urbanized. To accomodate urban development, low-lying lands would have to be raised to meet county flood-criteria elevations. Water levels at coastal structures in the major canals (Black Creek, Canal 102, and Mowry) could then be raised from 
the present operating level of 1.5 feet above sea level to 3.0 or possibly 3.5 feet above sea level. At these higher levels, the coastal controls would have to be opened for short periods to discharge flood water but, at other times, the controls would be closed. Thus, much of the water now discharged to the ocean could be conserved.

Raising water levels by coastal control structures will also raise water levels in the interior and reduce seepage from Conservation Area 3. These higher coastal levels would probably move the salt front in the Biscayne aquifer toward the sea. Unless carefully controlled, development would destroy the salt marsh-mangrove environment that fringes the coast. Dredging and filling necessary for development would damage the coastal zone. Permanent environmental degradation such as that experienced in north Biscayne Bay could occur. The reduced flow to south Biscayne Bay as a result of increased water levels would approximate the flows before the canals, and thus little alteration in the bay environment would be expected.

\section{Development in Flood-Prone Areas}

In the past, flooded land was drained by canals to permit urban development. In the future, because of impending water shortages, development of inland marginal and flood-prone areas will probably be by borrow-and-fill method which raises land above flood levels 11. Although this will minimize water losses and damage to aquatic environments, it will increase costs of land preparation, building, and installing utilities and roads. Most of the area developable by borrow-and-fill is west of the levee system.

\section{Deep Aquifer Storage of Storm Water}

A potential, although untested, method of conserving water is to store excess water in the upper part of the Floridan aquifer (see illustration).

This aquifer underlies the Biscayne aquifer and is separated from it by an 800 -foot-thick confining layer. The part of the aquifer between depths of 800 feet and 1,500 feet appears especially suited to injection, storage, and recovery of fresh water. Yields from large-diameter wells in this aquifer are more than 2,000 gallons per minute of brackish water of 2,000 to 5,000 milligrams per liter of chloride. Therefore, it is theoretically possible to inject under pressure fresh water at similar rates. The injected water should maintain itself as a lens of recoverable fresh water. As the aquifer is under high artesian head (40 feet above sea level), the water could be recovered by natural flow. This type of storage would eliminate evapotranspiration losses and could complement backpumping programs in a comprehensive water-management program.

Water would be injected during the rainy season from canals or from shallow wells in the Biscayne aquifer adjacent to canals. Pumping from shallow wells probably would minimize well clogging, a problem which reduces injection capacity.

The quantity of water pumped into storage over a period of years could be large enough to sustain needs in selected areas during an entire dry season or longer. In south Dade County clusters of injection-recovery wells located

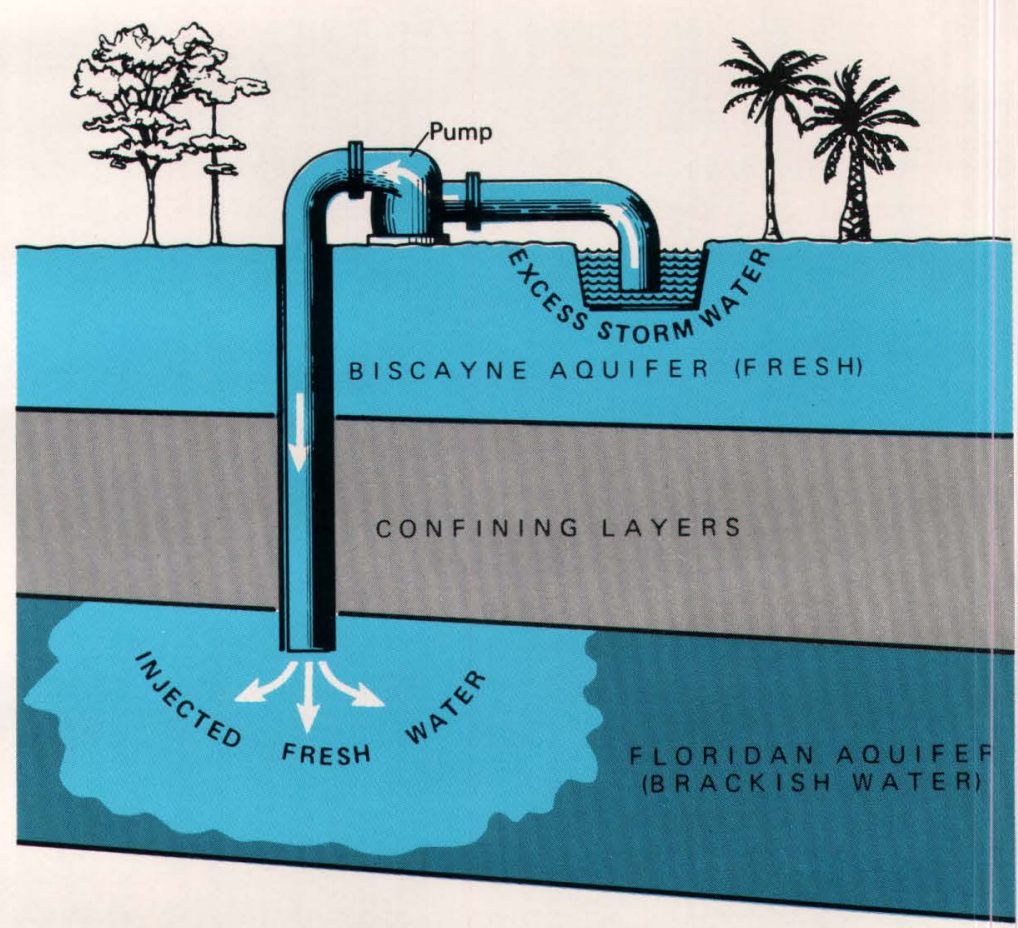

Injection of excess storm water into deep wells in the Floridan aquifer is a potential although untested method of storing fresh water for use during the dry season.

near the Orr-Southwest well fields, the Homestead Air Force Base well field, and the Homestead and Key West well fields could meet needs for future increases in municipal water supplies. Fresh water recovered from the Floridan aquifer could also supplement flows in some south Dade County canals during severe drought.

Further studies on the characteristics of the Floridan aquifer are needed to determine the practicability of this method.

\section{Reuse of Treated Wastewater}

In 1970, sewage treatment plants in Dade County discharged about $90 \mathrm{mgd}$ of wastewater to ocean outfalls and about $10 \mathrm{mgd}$ to inland canals $9 /$ By $1990,325 \mathrm{mgd}$ of wastewater will be produced, of which 90 percent probably will be discharged to ocean outfalls. Water discharged to the ocean is lost. Wastewater, however, if adequately treated, is a source of fresh water for well-field replenishment, for salinity control, for irrigation, and for maintaining wetlands. Although wastewater currently discharged into canals helps to maintain higher water levels at control structures during the dry season, the water is of low quality and contaminates the waterways.

Properly treated wastewater could be piped from central treatment plants to the coast and injected into the Biscayne aquifer to help retard sea-water intrusion. Wastewater treated for removal of nutrients, toxic chemicals, and bacterial contamination also could be discharged directly to canals to insure continual recharge of the Biscayne aquifer.

Treated wastewater could also be piped inland to waterconservation areas or to wetlands west of Levee 31 (see illustration). This would retard recession of water levels in these areas and help sustain flows to Everglades National Park as well as to canals. If, however, the wastewater contained nutrients the growth of vegetation in the wetland areas would be stimulated. 


\section{Other Approaches to Increasing Water Availability}

Another approach to control sea-water intrusion is the injection of brackish water from the Floridan aquifer into the salt front of the Biscayne aquifer ${ }^{13}$. The agitation created by injection and the dilution caused by the salinity differences could push back or at least retard the inland movement of the salt front during drought periods (see illustration). Studies are needed to determine the effectiveness of this approach.

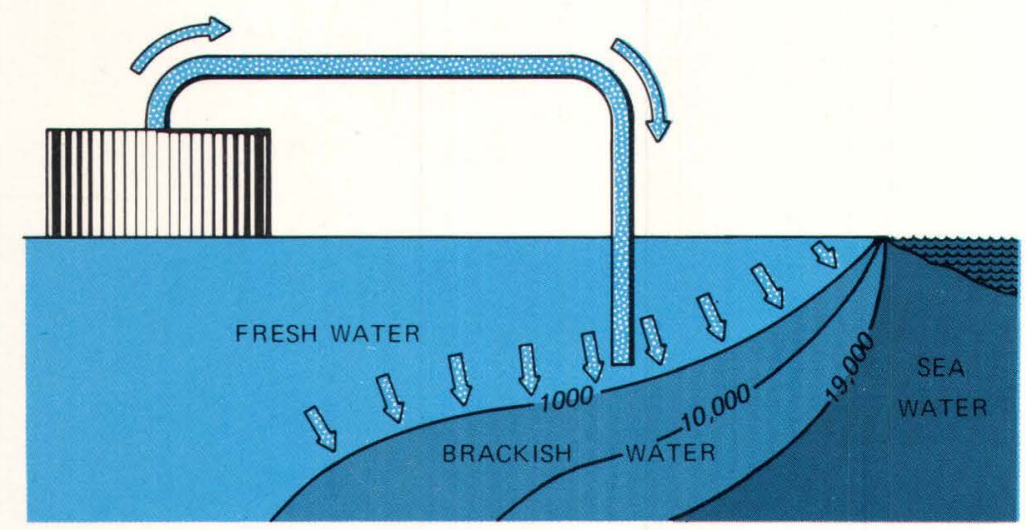

Treated wastewater could be backpumped to Conservation Area 3 or other interior wetlands to maintain water levels. The quality of the wastewater, however, may affect plants and animals in the area.

Other methods of increasing the availability of water in southeast Florida would affect the south Dade area. Proposed methods include backpumping in counties north

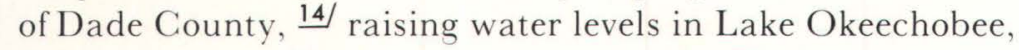
desalting water from the sea or from the Floridan aquifer, use of evaporation suppressants, and weather modification. Backpumping or raising water levels in Lake Okeechobee would reduce canal discharge to the ocean and require pump installations and other construction. Deterioration of the water quality of Lake Okeechobee is probable if the water backpumped is enriched with nutrients and other contaminants from agricultural and urban areas. The rise in lake level probably would alter perimeter marshes, which if destroyed would adversely affect water quality.

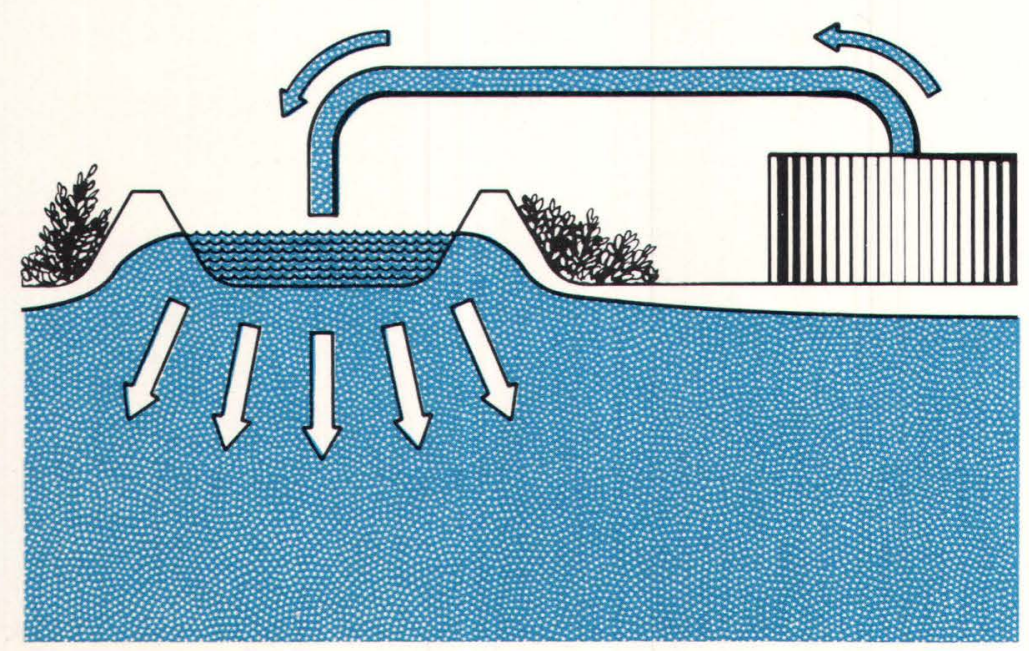

Treated wastewater could be piped to the coast and injected into shallow wells in the Biscayne aquifer to retard sea-water intrusion in selected areas. .2

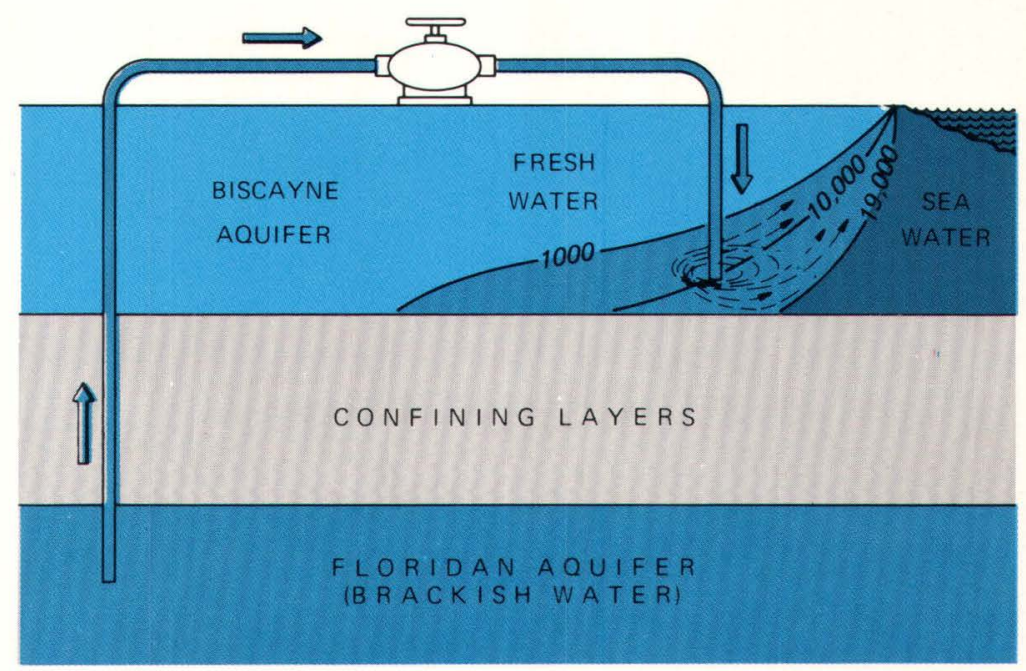

Artesian water of relatively low salinity from deep wells could be injected into shallow wells along the coast to retard sea-water intrusion in the Biscayne aquifer.

\section{Future Management}

The current water-management system for south Florida is a complex network of water-conservation areas, canals, salt-water barriers, and other physical features. Both the existing system and a system with modifications offer opportunity for alternatives to management.

Assessment of alternatives for future management procedures will require close coordination with planning agencies so that realistic objectives and alternatives for implementation can be formulated. Limitations on available water will undoubtedly affect land-use planning; similarly, land-use decisions will influence the selection of management alternatives. 


\section{ENVIRONMENTAL QUALITY}

South Dade County has flat land, mild weather, plentiful but seasonal rainfall, and a great diversity of plants and animals common to tropical and temperate zones. The mild weather, clear skies and water, and sunny beaches attract people to the region. Tropical storms and diseases are unfavorable aspects.

Before man arrived in numbers, much of the area was marsh or wet prairie, but sizable areas were forested. The largest forests, predominantly pine and tropical hardwoods, occupied the coastal ridge. The forests and prairies were choice habitats for deer, bear, and panther. The coastal areas were forested by tropical hardwoods and palms on elevated land above the tidal influence and by salt-tolerant trees such as mangroves and buttonwood on land periodically flooded by salt or brackish water.

Marine life, in the area was essentially tropical. The clear, warm waters allowed the development of diverse and productive coral reef communities, the northernmost limit of such reefs. The advent of man has changed life on the land radically and has begun to affect marine life.

Open forests of pine, palms, and hardwoods are choice habitats for deer and other mammals.
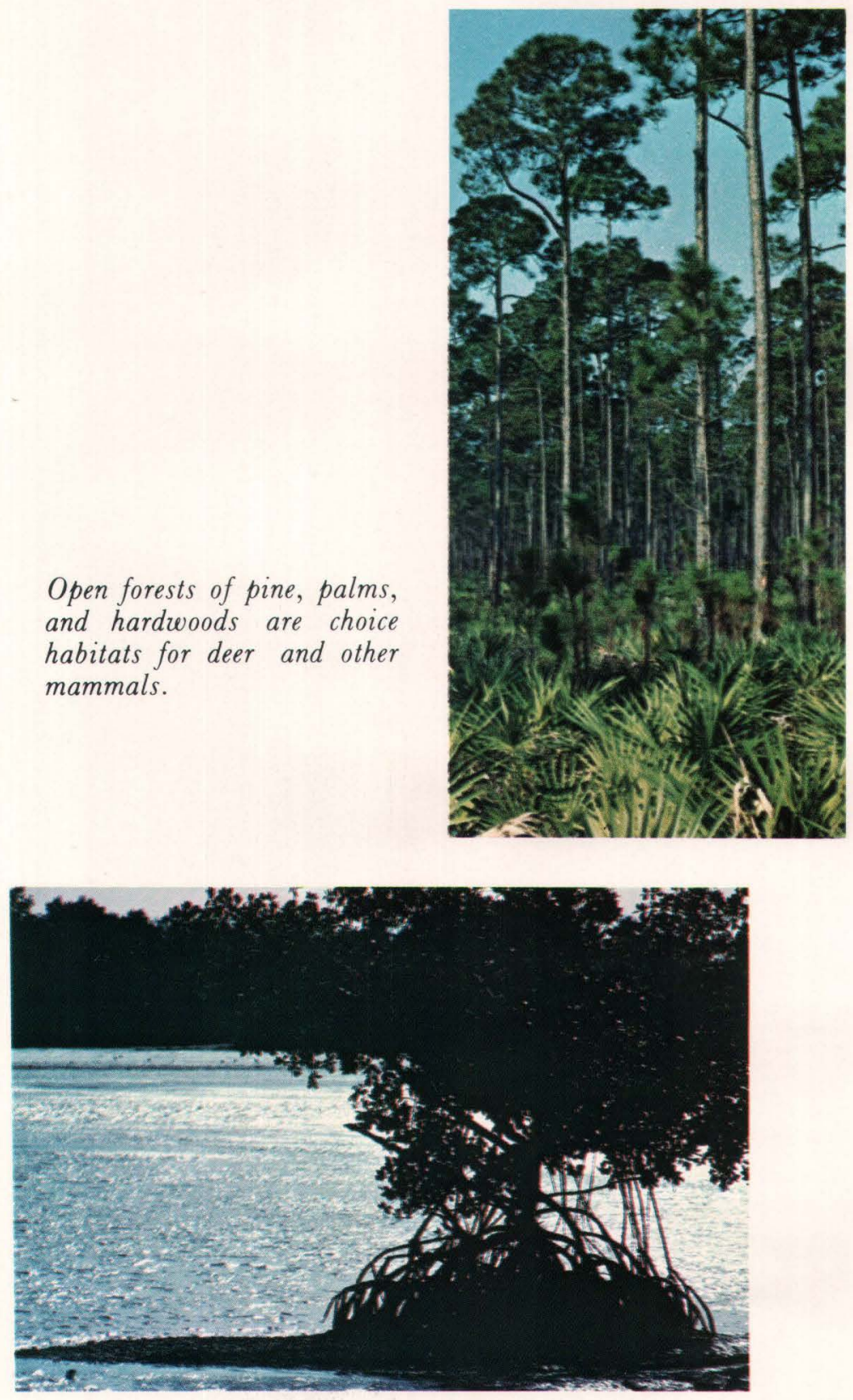

The red mangroves of the coastal forest are land builders. Their prop roots also provide shelter and a place of attachment for small organisms, and their leaves, which decay in the water, are the main source of food in the estuary.

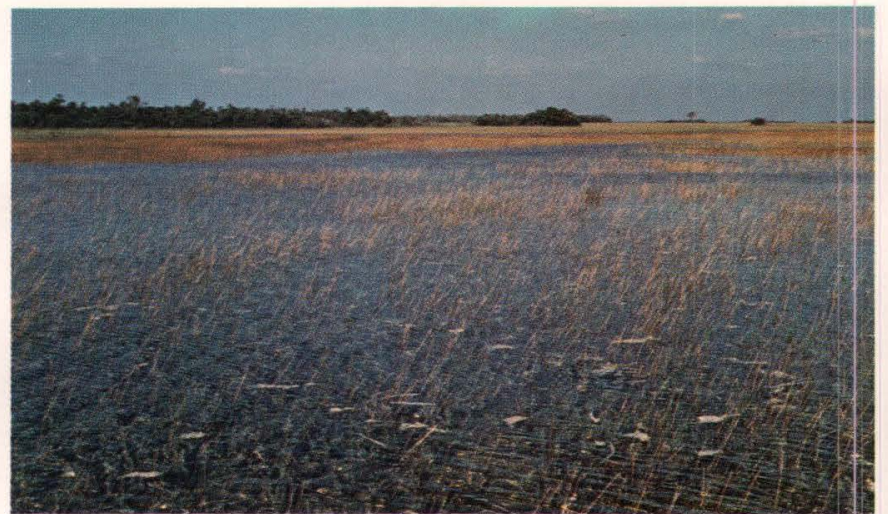

Sloughs are shallow watercourses. Shark River Slough is the largest watercourse through which fresh water flows to the principal estuaries of Everglades National Park.
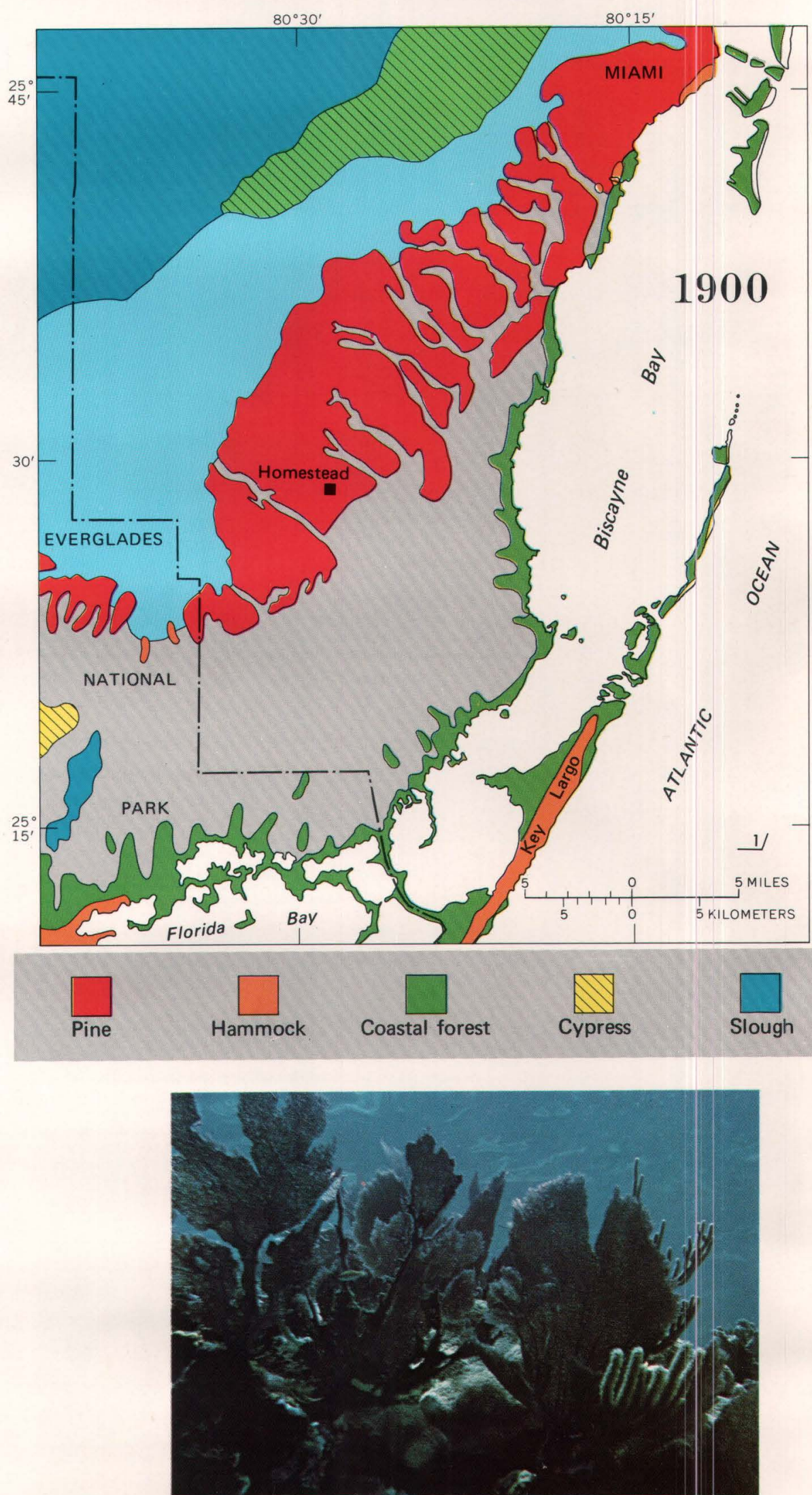

A coral reef is a rich diversity of life that thrives only in shallow tropical seas. 


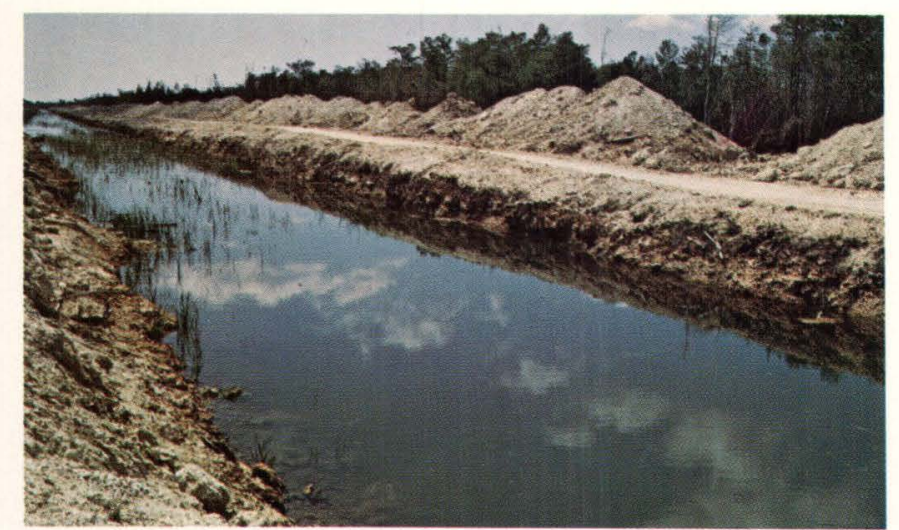

Large areas of original wetland have been drained.The canals have affected the remaining wetlands by reducing the period of flooding, and this has increased the oxidation of soils.
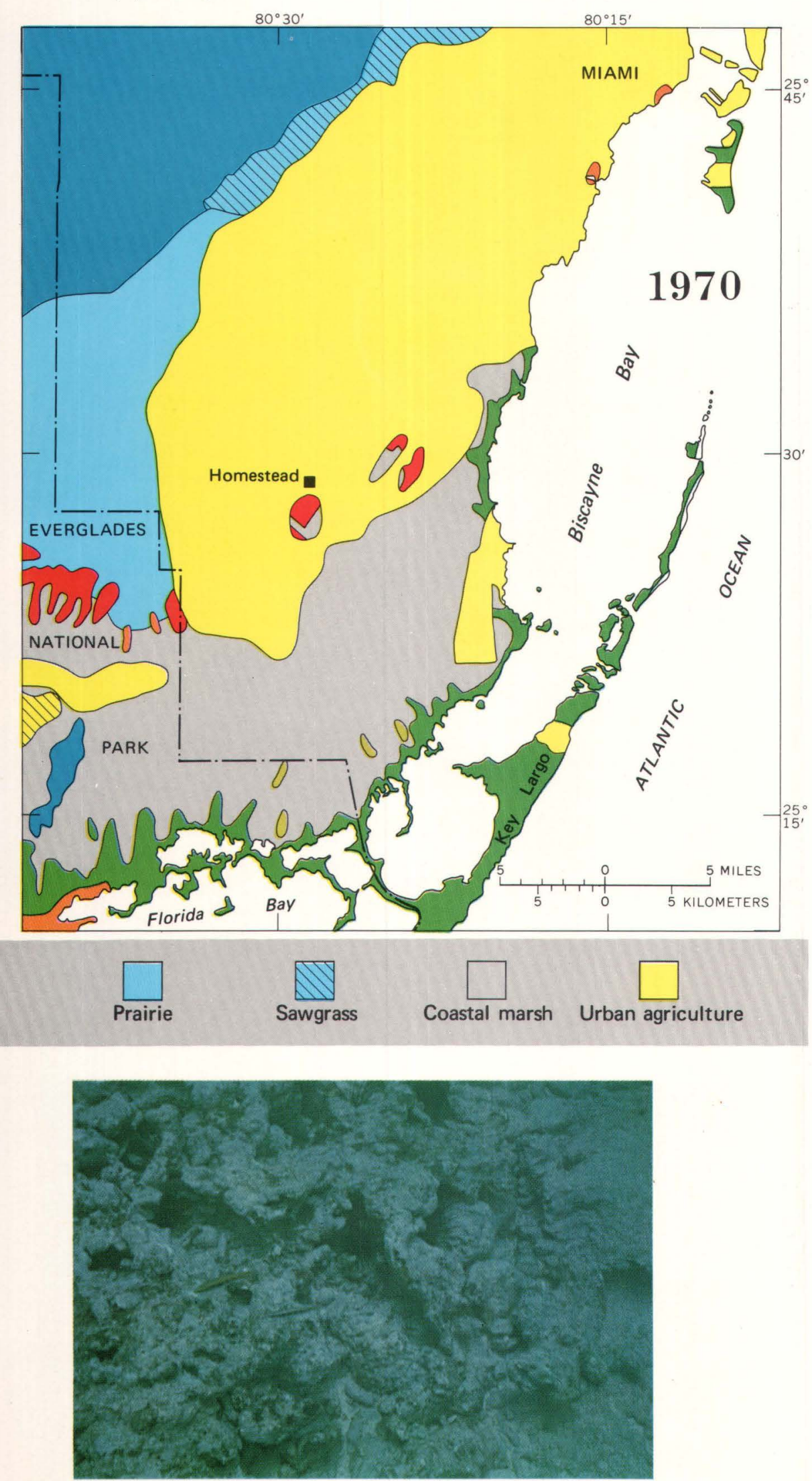

Coral reefs can be damaged by collection of specimens, increased silt from dredge and fill, and pollution from ships and from the land.

\section{Impact on the Ecosystem}

The major adverse impacts of man on south Dade County began in the early 1900 's with extensive drainage, dredge and fill, and agricultural and urban development. Early drainage of the Everglades has resulted in serious and largely irreversible changes in the south Florida ecosystem. Direct effects include a reduction of wetland, major changes in the direction of water flow and duration of flooding, oxidation of peat soils, and salt-water intrusion. Indirect effects of drainage include a massive decline in colonial wading birds from over a million in 1935 to less than 200,000 in 1970 , a reduction of animal populations such that 20 species are now classed endangered, and a significant deterioration of water quality $2 /$.

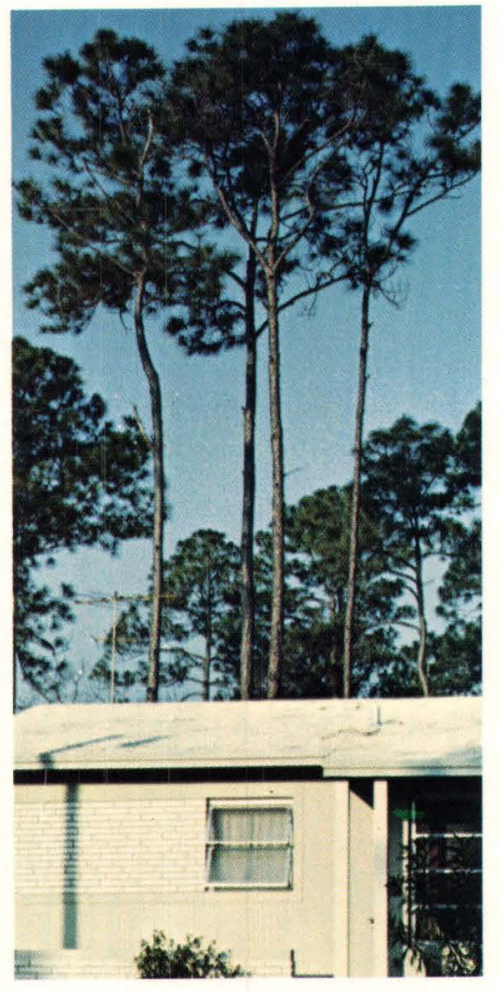

More than 300 square miles of natural pine and wetland of the Coastal Marsh have been changed to residential or agricultural land in the south Dade area.

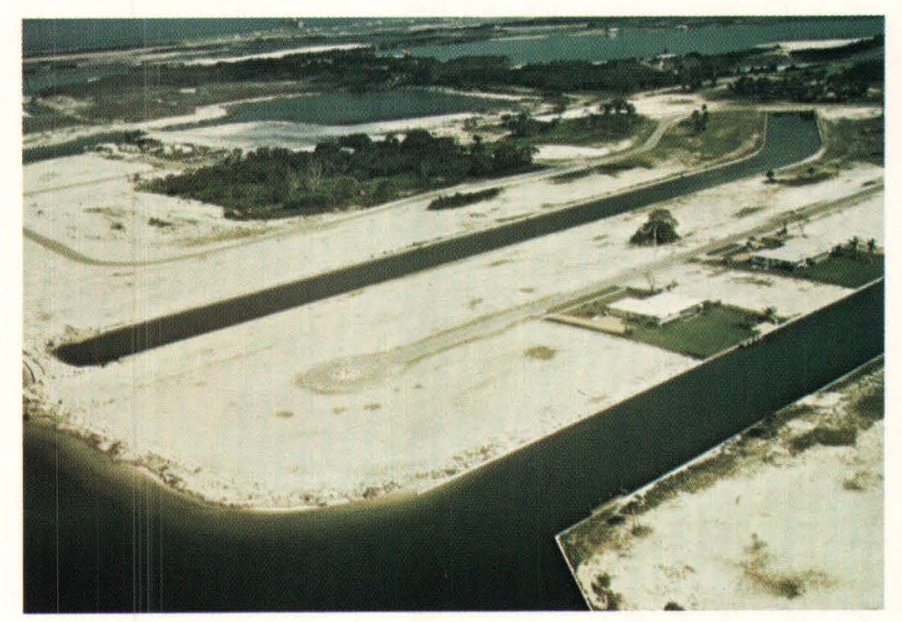

Dredging and filling provide water-front real estate but destroy vital mangrove swamps. 


\section{ENVIRONMENTAL QUALITY}

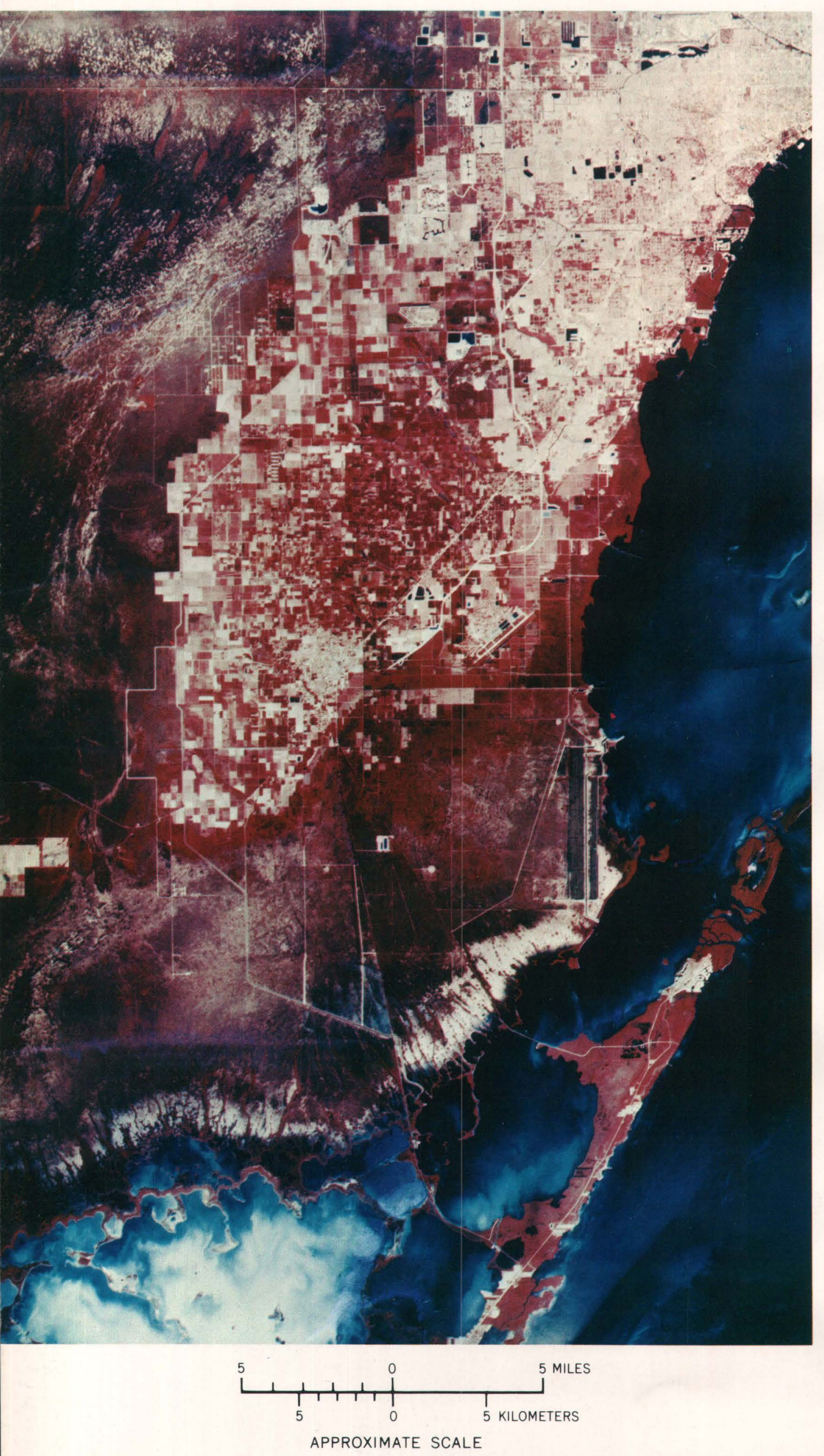

Dredging and filling of estuarine areas has seriously altered north Biscayne Bay and is a potential hazard to the south Bay. These shallow estuarine waters are important nursery grounds for many marine organisms, including commercially important species. Food for these species is provided by peripheral mangrove swamps and shallow seagrass beds. Destruction of these habitats has seriously reduced the productivity of the Bay.

Man has adversely affected the ecosystem in many other ways, including the introduction of exotic plants and animals, the release of persistent toxic chemicals and excessive nutrients, the cutting of forests, overfishing, and uncontrolled urban sprawl.

Color infrared photography of south Dade County (1973) vividly shows man's impact on the land. 


\section{ENVIRONMENTAL QUALITY}

Agriculture has also contributed to pollution. The amount of land now (1973) in agricultural use in Dade County is about 92 square miles, mostly in the south part of the county.Fertilizers and pesticides are the main agricultural contaminants. Nutrients, such as nitrogen and phosphorus, and potentially toxic metals,such as copper, lead and arsenic from agricultural fertilizers, are leached from farm soils or are carried on soil particles into surface and ground waters. Pesticides are generally insoluble in water and are usually transported from farms either in runoff or on dust particles.

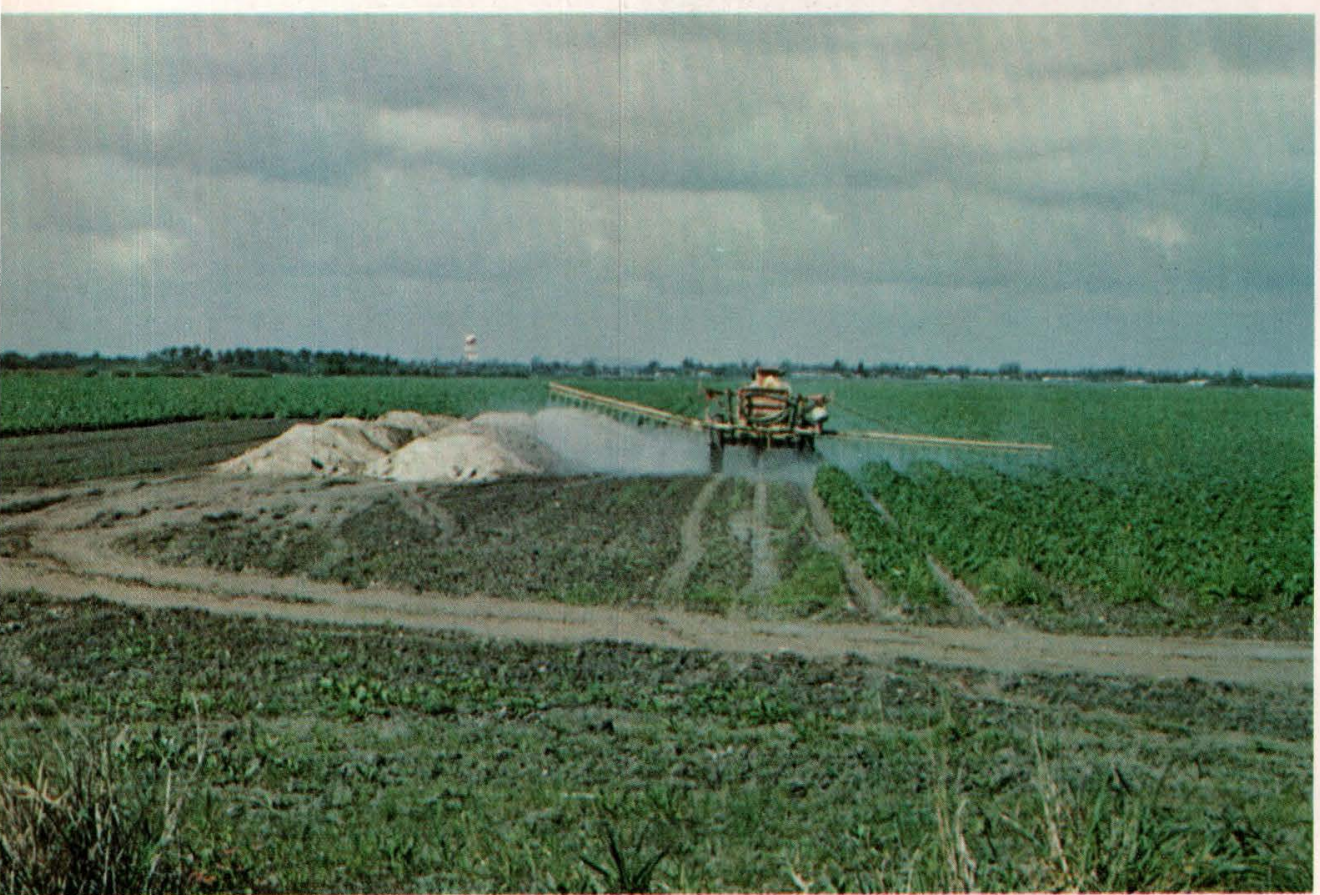

Although economically important for south Dade, agriculture is a major source of pollution.

The urban environment constitutes the major source of solid, liquid, and gaseous waste. Per capita liquid and solid waste will increase while per capita gaseous wastes should decrease when Federal emission standards for automobiles are implemented.

Liquid waste production in south Dade County was more than 16 billion gallons in 1972. Half was discharged to septic tanks. Sewered areas are served by 29 treatment plants which discharge to the ocean, canals, and seepage ponds 3 ! The long-range master plan for Dade County provides for replacement of the smaller privately owned treatment plants with four large facilities ${ }^{4}$. While the four large

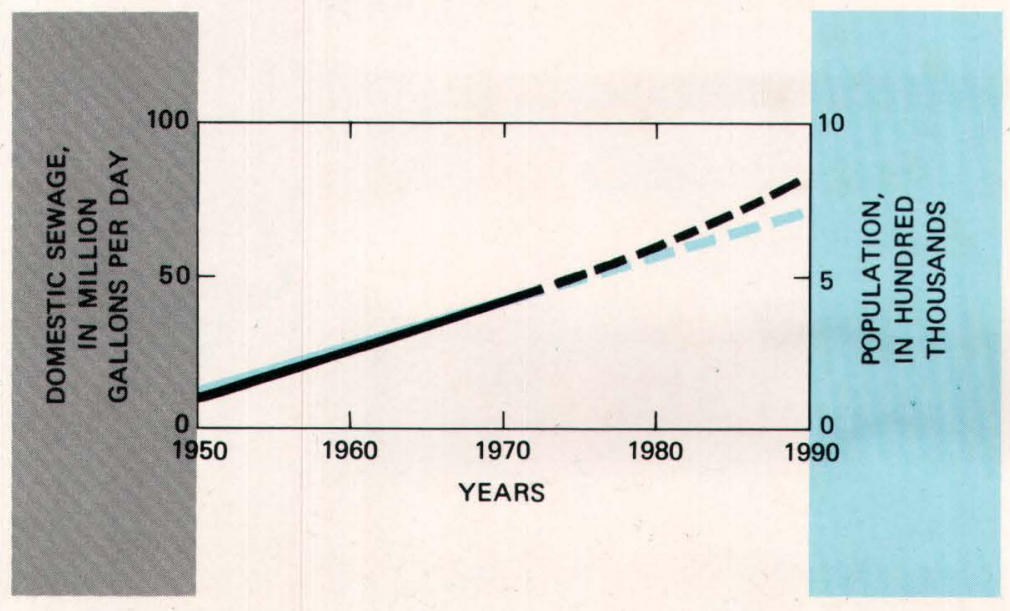

Liquid waste is projected to increase about eight times between 1950 and 1990 in south Dade. plants are being constructed, however, Dade County will allow construction of 200 additional small treatment plants that will provide 90 -percent treatment efficiency. The treated effluent from these small plants will be discharged to pits. Some of this effluent will infiltrate the Biscayne aquifer.

Each person in south Dade County in 1970 generated about one ton of solid waste, or a total for the area of about 400 thousand tons per year. By 1990 the total solid waste will approach one million tons per year, according to recent projection (see graph). Disposing of this solid waste is difficult because of the geology and hydrology of the area.

In 1970, about 30 percent of the solid waste was incinerated while the remainder was disposed of in dumps and

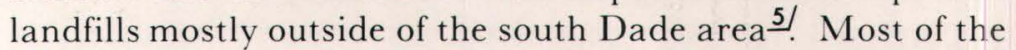

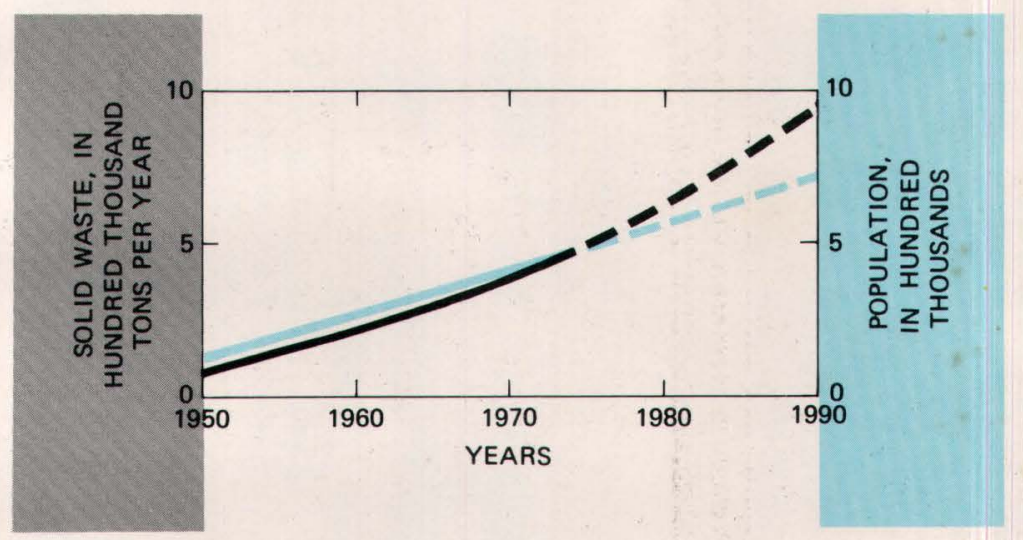

Solid waste is projected to increase almost 10 times between 1950 and 1990.

incinerators and dumps do not meet pollution code requirements. Malfunctioning incinerators emit toxic gases and particulate matter, and open dumps and landfills are esthetically unpleasant, susceptible to fires which pollute the air, and sources of contaminants to shallow ground water.

Plans for solid-waste disposal in Dade County call for improved efficiency of incinerators and for sanitary landfills to replace open dumps. Estimated county costs for these needed improvements will exceed 100 million dollars in the next 20 years 6 ?

In south Dade County, about 80 percent of the airborne contaminants come from more than 260,000 vehicles, which use 220,000,000 gallons of gasoline each year. In addition, some contaminants from fuel combustion for heat and power reach the atmosphere.

\section{Nutrients}

Nutrients, particularly nitrate and phosphate, stimulate plant growth. Treated sewage is the largest source of the heavy nutrient content in the canals and other waters of the area.

The overstimulation of water-plant growth by excess nutrients produces great variations in the oxygen content of water during a single day. By day plants produce oxygen through photosynthesis, and at night they consume oxygen. The nightly demand for oxygen in combination with the oxygen requirements for decay of organic matter in treated sewage effluents can lower the oxygen content of water below levels that fish and other aquatic organisms require for survival. 
In south Dade County, the highest concentrations of phosphate in the surface waters are shown on the map below.

Water moving through canals flushes nutrients into Biscayne Bay and provides fresh water which satisfies decay and respiration demands for oxygen. During the dry season, however, flow through the canals decreases sharply.
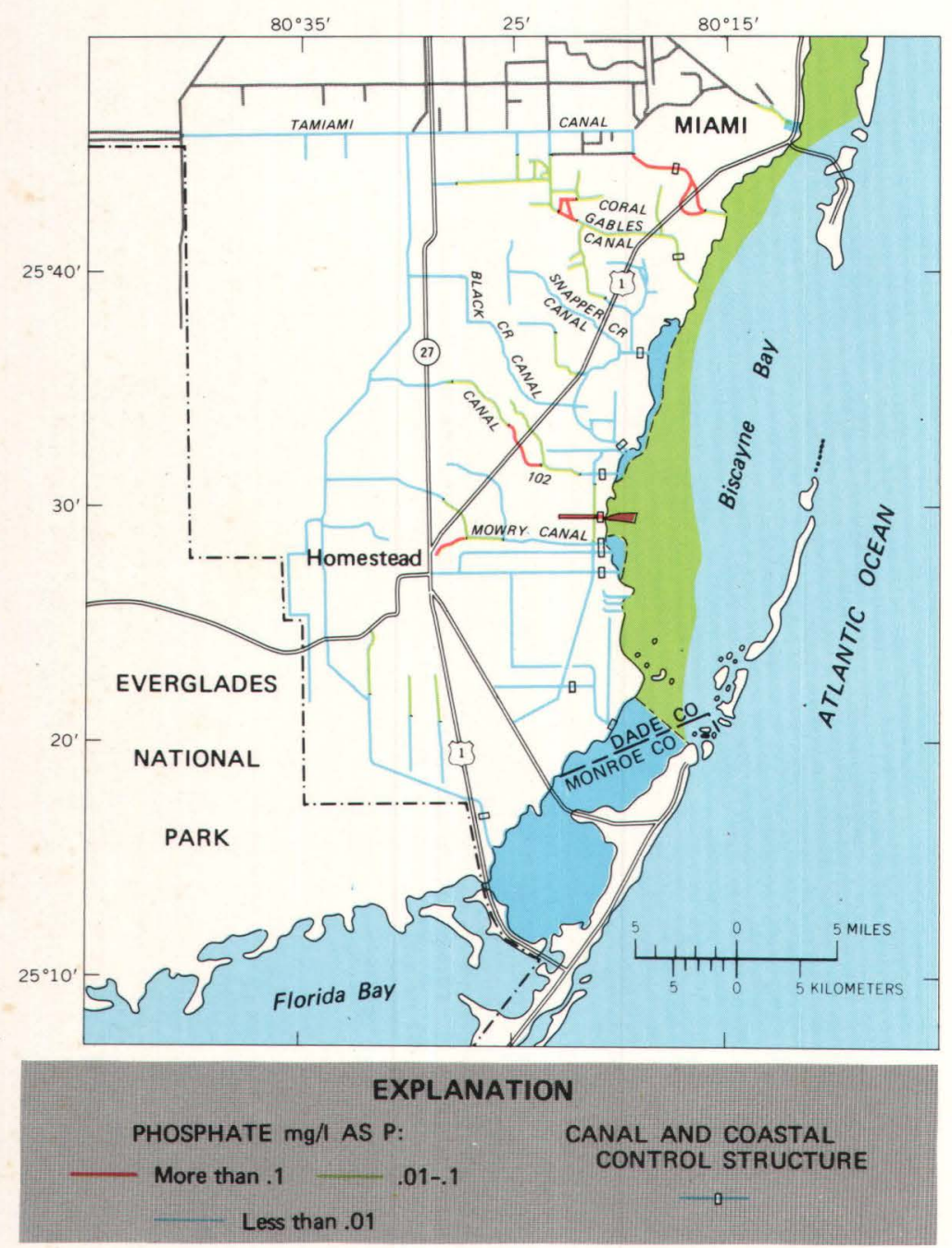

The January 1973 survey showed higher concentrations of phosphates in the urbanized areas.

When nutrients build up in the stagnant canals, aquatic blooms, fish kills, noxious odors, and health hazards can occur. Increased urban water use decreases the amount of water available for flushing of the canal system. The combined impact of increased nutrient load and reduction in flushing action can seriously damage aquatic environments.

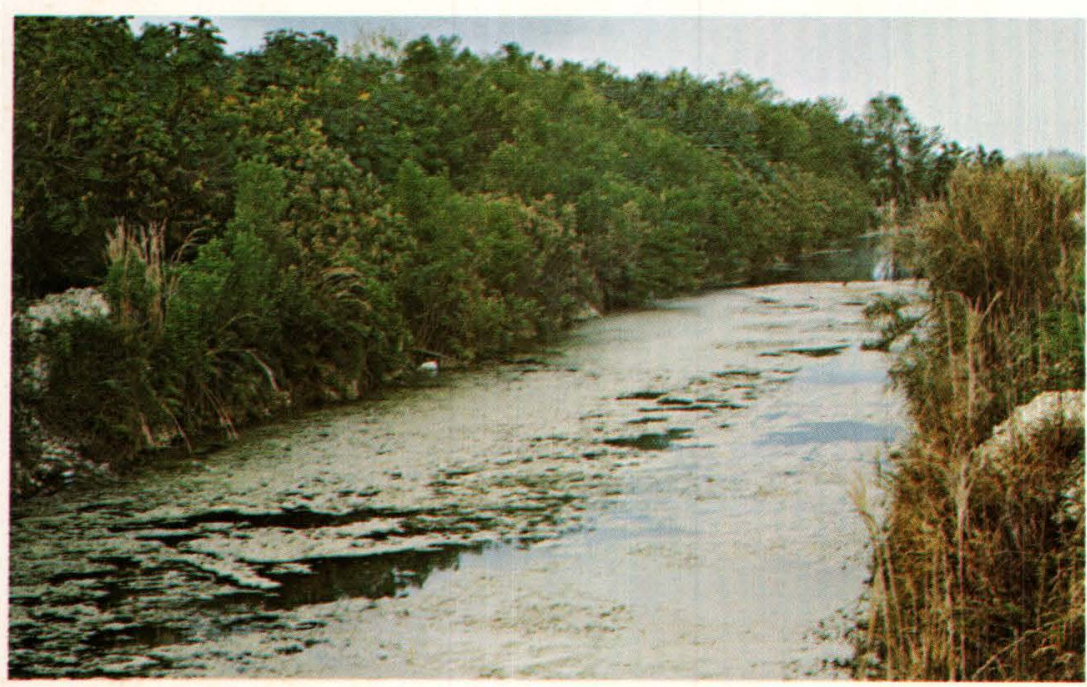

Nutrients flushed from farm and residential lands in south Dade cause thick algal blooms in canals.
Biscayne Bay, the temporary repository of urban wastes, is now over enriched in phosphorus. It is low in nitrogen which indicates that additions of nitrogen probably regulate the rate of vegetative growth in the Bay. The amounts of phosphorus and nitrogen added to Biscayne Bay can be lessened by tertiary waste treatment.

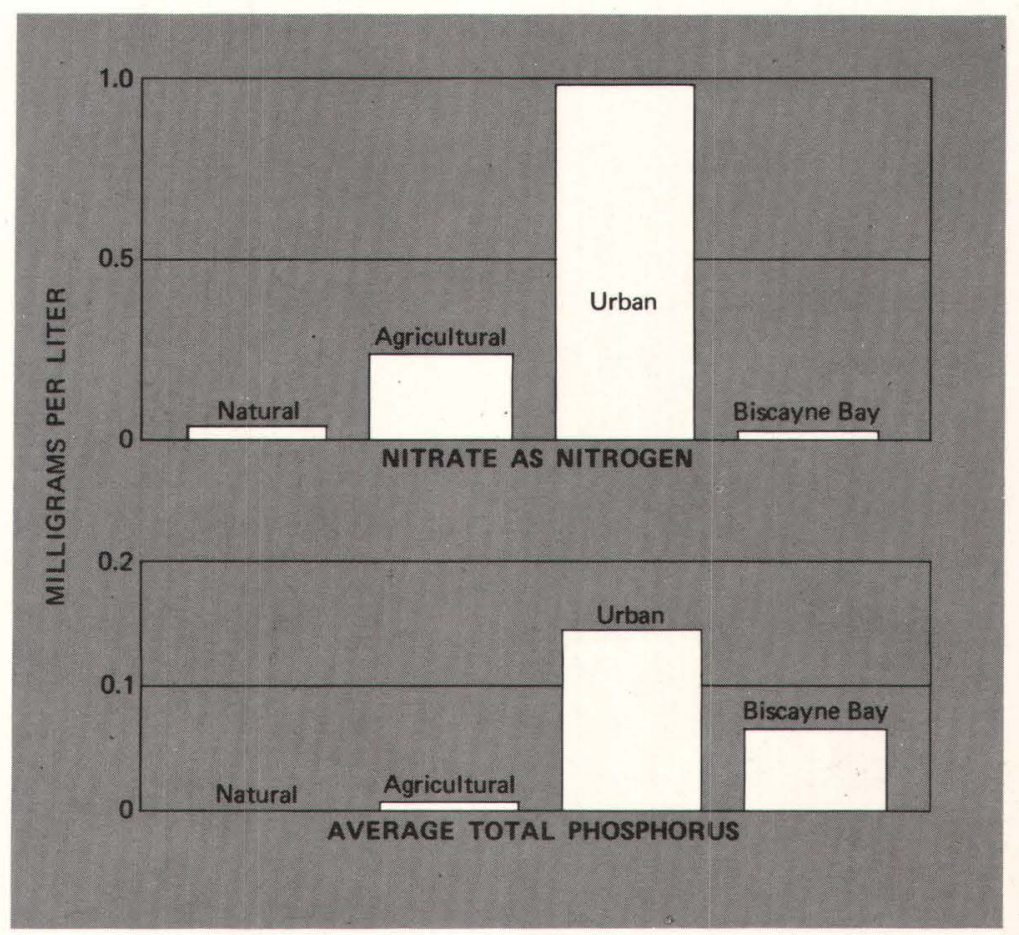

A survey in January 1973 showed that concentrations of nitrate and phosphorus were highest in the urban areas of south Dade County.

\section{Toxic Metals}

Lead and mercury are the two metals known to be accumulating in this area. Crude estimates suggest that more than 3,000 metric tons of lead are added to the area each year (see illustration below). Much of this is from automotive exhaust and is deposited within several hundred yards

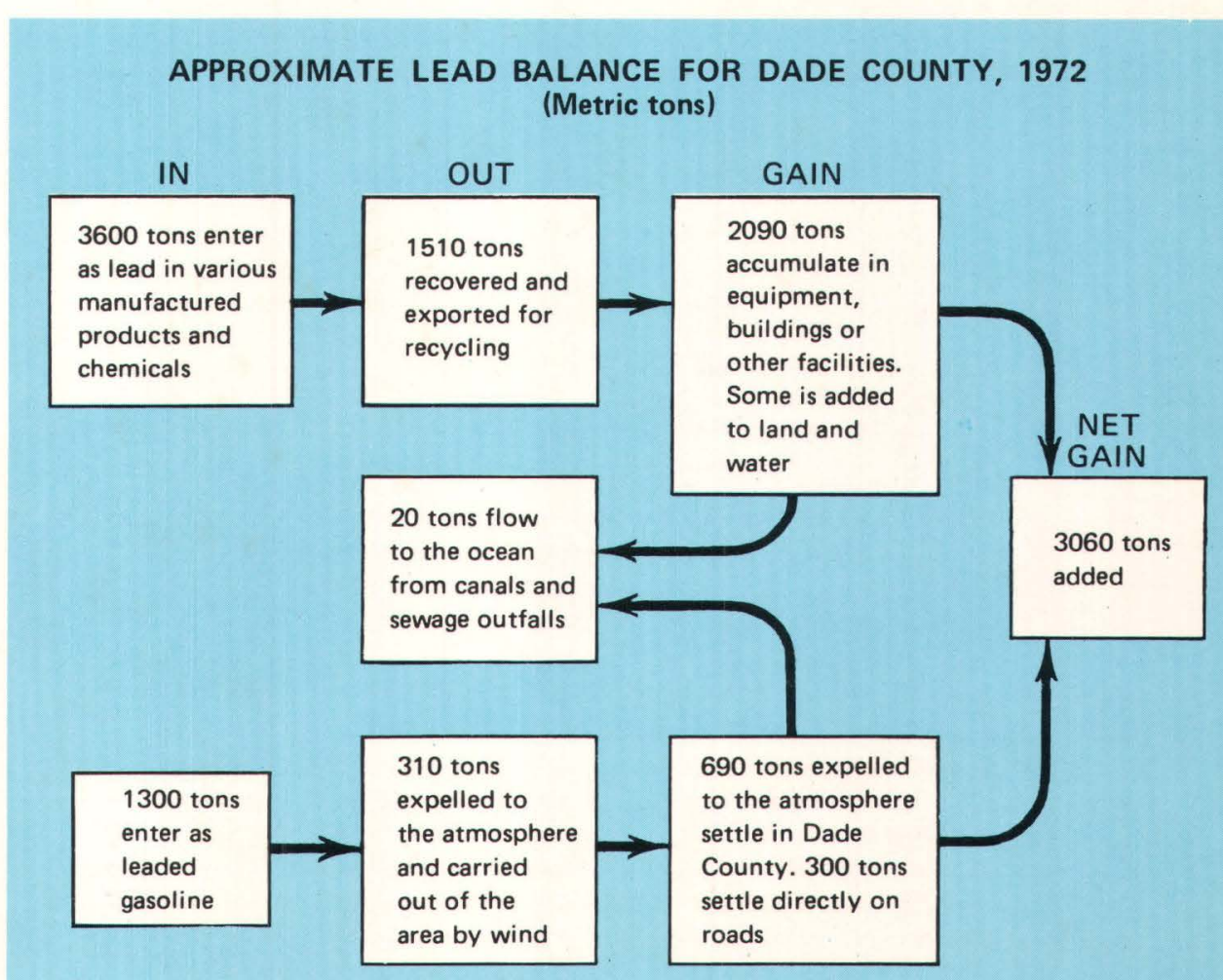




\section{ENVIRONMENTAL QUALITY}

of the highways. Concentrations in bottom sediments of Biscayne Bay are low, ranging from 15 to $30 \mu \mathrm{g} / \mathrm{kg}$ (micrograms per kilogram; $1 \mu \mathrm{g} / \mathrm{kg}=1$ part per billion). Somewhat higher concentrations occur at the mouth of Miami River and Black Creek Canal, indicating that some lead is transported in runoff.

The 990 metric tons of lead settling in Dade County from automobile exhaust emissions, provides the greatest toxic metal hazard. About 310 metric tons of lead from exhaust emissions in Dade County settles in the land and waters of the Everglades Basin. Another 20 metric tons flows into Biscayne Bay and the ocean.

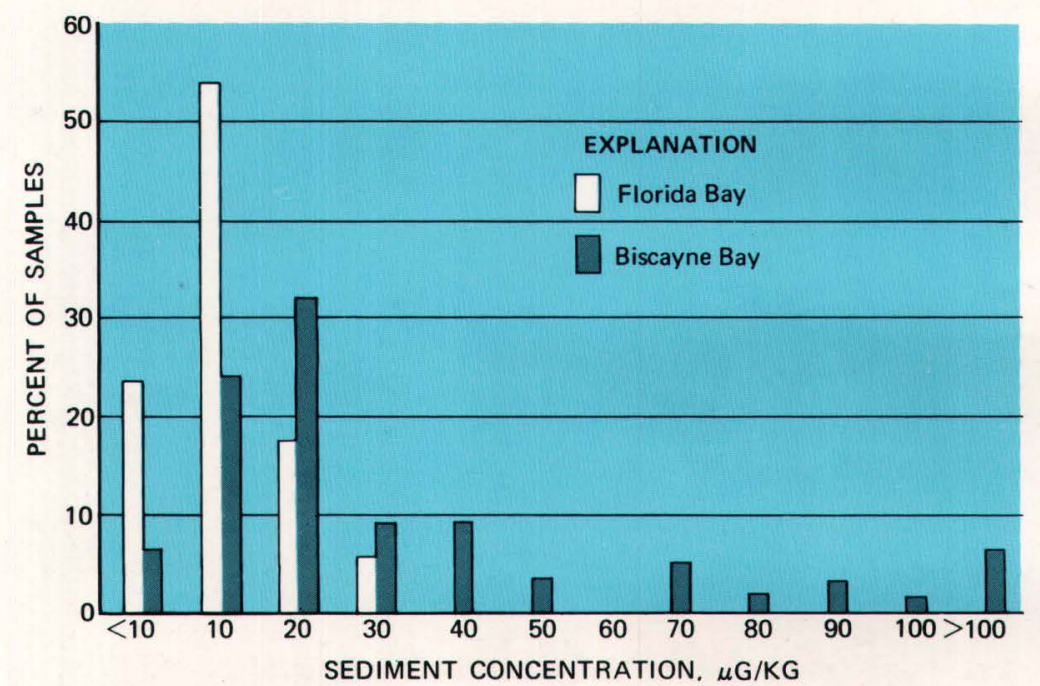

Mercury is contained in bottom sediments of Florida and Biscayne Bays. 7$]$

Biscayne Bay shows some contamination by mercury when compared with Florida Bay, an area remote from rapid development (see graph). Mercury in the bottom sediments of Florida Bay ranged from 10 to $40 \mu \mathrm{g} / \mathrm{kg}$ and averaged $10 \mu \mathrm{g} / \mathrm{kg}$. Bottom sediments in Biscayne Bay ranged from less than 10 to $325 \mu \mathrm{g} / \mathrm{kg}$ and averaged $40 \mu \mathrm{g} / \mathrm{kg}$ of mercury.

The degree of mercury contamination in Biscayne Bay sediments is quite low compared to average levels reported in sediments from southern Lake Michigan $(150 \mu \mathrm{g} / \mathrm{kg}) \frac{8}{\text {, the }}$ South Bay portion of San Francisco Bay $(370 \mu \mathrm{g} / \mathrm{kg}) \frac{9}{2} / \mathrm{or} \mathrm{Mini-}$ mata Bay, Japan, where 46 people died from mercury poisoning incurred by eating shellfish from mud containing 22,000 to $59,000 \mu \mathrm{g} / \mathrm{kg}$. Nevertheless, the fact that mercury can build up to levels as high as $325 \mu \mathrm{g} / \mathrm{kg}$ in individual locales of Biscayne Bay is a matter of concern.

\section{Pesticides and Related Compounds}

Pesticides include a wide variety of chemical compounds. Some are persistent; others are nonpersistent. The persistent ones, such as DDT, dieldrin, and toxaphene, do not break down rapidly and accumulate in the environment.

Nonpersistent pesticides, such as malathion or parathion, are most commonly used in Florida, especially in the south Dade area where they are applied in citrus groves and vegetable farms 10 . In 1969-70, they were applied to about 11,900 acres of citrus groves and 47,000 acres of vegetable farms in Dade County 11 . Approximately one million pounds of persistent pesticides were used annually on urban and agricultural land in the 1960's in Dade County.12/.

Both persistent and nonpersistent pesticides are found in air, water, plants, and animals of south Dade County, with persistent ones such as DDT predominant. Concentrations are usually at trace levels or below detectable levels in water, but at higher levels in bottom sediments and biota. Concentrations in excess of $1,000 \mu \mathrm{g} / \mathrm{kg}$ have been found in birds and mammals $\stackrel{13 /}{ }$. A concentration of over $16,500 \mu \mathrm{g} / \mathrm{kg}$ was measured in one bald eagle.

\begin{tabular}{|c|c|c|}
\hline \multicolumn{3}{|c|}{$\begin{array}{l}\text { BIOLOGICAL MAGNIFICATION OF A } \\
\text { PERSISTENT PESTICIDE IN DADE COUNTY } 14\end{array}$} \\
\hline \multicolumn{3}{|c|}{$\begin{array}{c}\text { Concentration of DDT family } \\
\qquad \mu \mathrm{g} / \mathrm{kg}\end{array}$} \\
\hline COMPONE & & \\
\hline Surface water & & 0.02 \\
\hline Rainfall. . . & & .30 \\
\hline Marsh soil. & & 16 \\
\hline Crustaceans & & 23 \\
\hline Small fishes. & & 196 \\
\hline Alligators. . & & 352 \\
\hline Bald eagle & & 16,500 \\
\hline
\end{tabular}

Buildup of persistent insecticides in some birds causes metabolic upset in their reproductive processes. Increasing concentrations of DDT are coincidental with death and decreasing numbers of some species, particularly hawks, eagles, and pelicans. Even though local use of DDT and other persistent insecticides is decreasing, a buildup may continue for years as a result of the long life of some pesticides (up to 20 years for the DDT family) and as a result of extensive use in other parts of the world and ultimate atmospheric transport to Dade County. This is of particular concern in the Everglades National Park because birds are an important attraction.

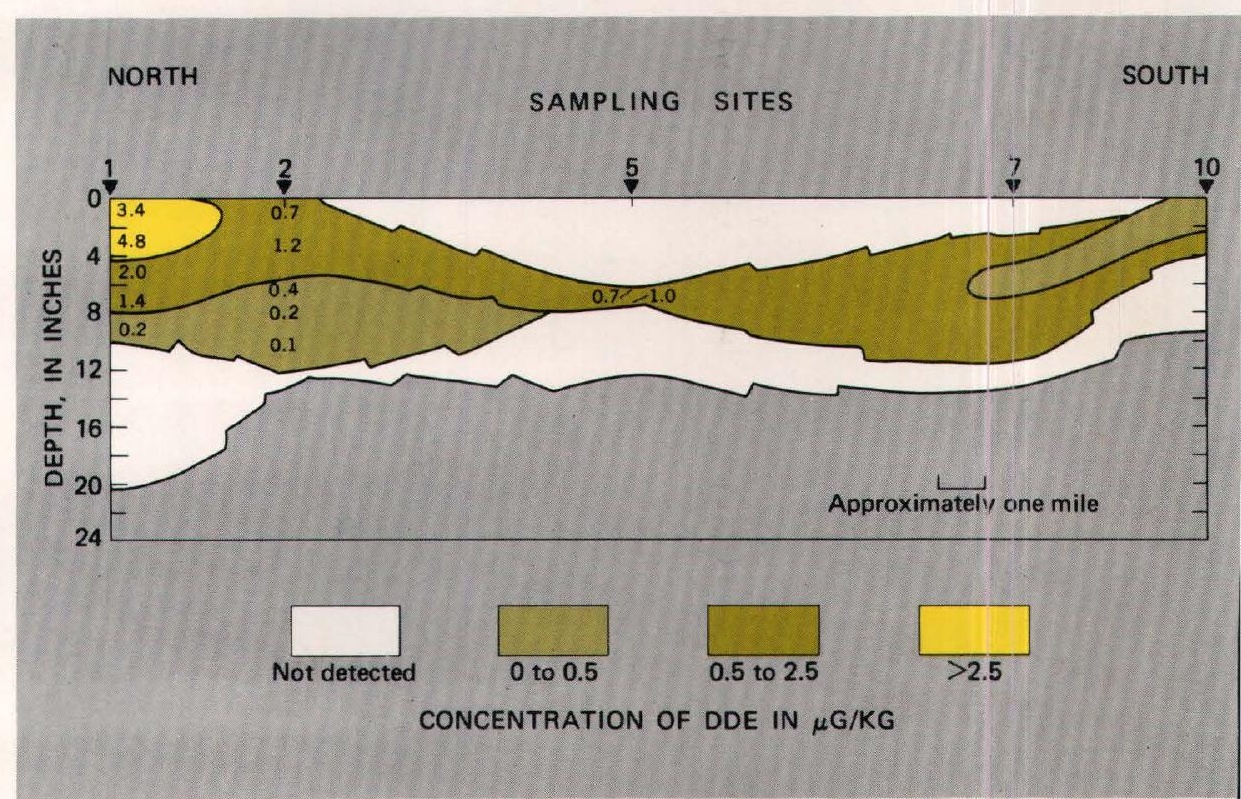

$D D E$ occurs in the near-shore bottom sediments of the northern half of Biscayne Bay.

Pesticides accumulate in humans to levels thousands of times greater than those in the water they drink and the food they eat. Average concentrations of total DDT in human fat from Caucasians more than 5 years old in Dade County was $8.4 \mu \mathrm{g} / \mathrm{kg} \frac{15}{}$. For comparison, concentrations in Caucasians from 22 other States ranged from 3.98 to $13.23 \mu \mathrm{g} / \mathrm{kg}$. States with warm climates had higher averages $(9.21 \mu \mathrm{g} / \mathrm{kg})$ than States with cool climates $(4.85$ $\mu \mathrm{g} / \mathrm{kg} 15$. The effects of such concentrations on human health are not known. 


\section{Bacteria and Viruses}

Most inland canals, lakes, and ponds in south Dade County are unsafe for swimming and contact sports because of fecal contamination. Feces often contain pathogenic bacteria and viruses. Only three of ten major canals are considered safe for swimming, and only ocean beaches are generally recommended for water-contact sports. Also significant is the fact that during the dry season the canals provide recharge directly to the Biscayne aquifer. Because water supplies are withdrawn from this aquifer, a potential exists for contamination of public water supplies.

Bacteria and viruses have been detected repeatedly at ocean outfalls for untreated sewage, but no pathogenic viruses have been detected at outfalls for treated sewage. Preliminary data from a limited study have also failed to indicate pollution of ground water by effluent from septic tanks.

Because of bacterial and viral contamination, commercial shellfishing for direct marketing is prohibited along the entire east coast of south Florida.

\section{Thermal Pollution}

Thermal pollution in the south Dade area is from two fossil fuel and one nuclear power plants at Turkey Point. The fossil-fuel units require $1,270 \mathrm{cfs}$ of cooling water and raise the water temperature $12^{\circ} \mathrm{F} \frac{16}{}$. The nuclear unit requires $4,250 \mathrm{cfs}$ and raises the water temperature $16^{\circ} \mathrm{F}$.

Investigations by the University of Miami and the Environmental Protection Agency show that the release of heat from the existing fossil-fuel plants has affected

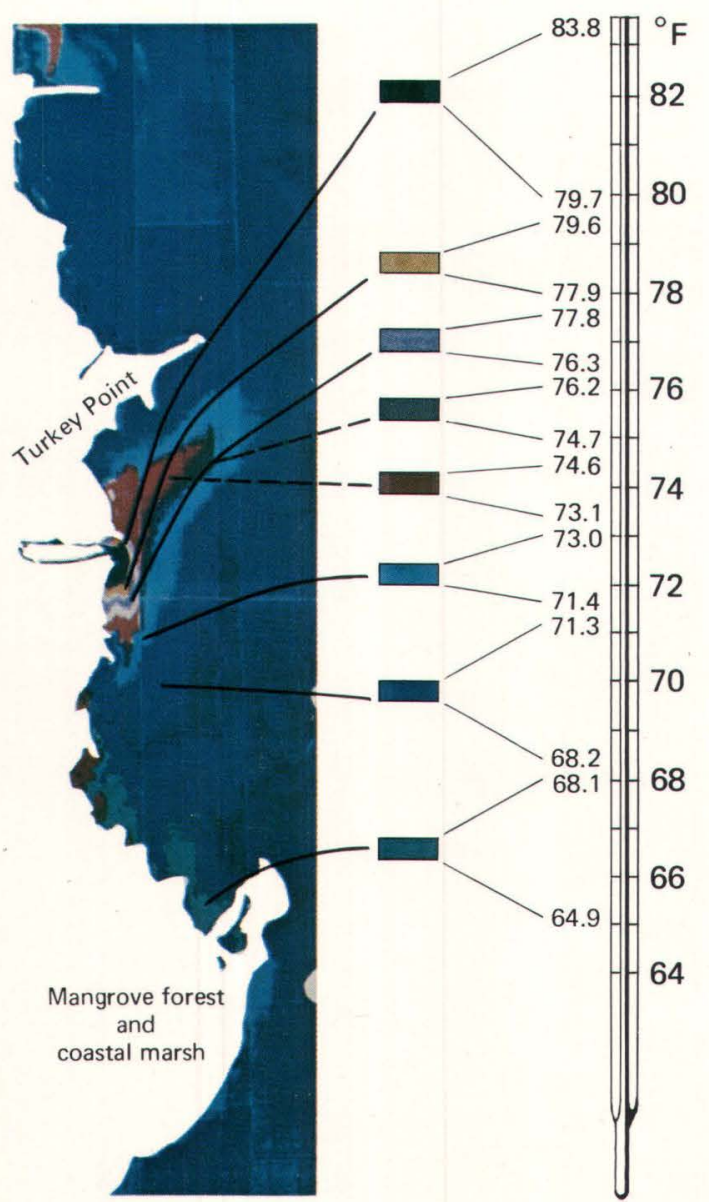

Shown here is a false color infrared photo of the coastal area at Turkey Point. the biota of south Biscayne Bay. Plankton, benthic algae, sea grasses, benthic invertebrates, and fish were all significantly affected by elevated temperatures near the discharge area. The most obvious effects were the decreases in the number of algal species and the death of sea grasses over an area of several hundred acres of bay bottom. In general, animals were adversely affected by temperatures above $91^{\circ} \mathrm{F}$.

A huge system of canals under construction on a 10-square-mile area will serve as a cooling radiator for the heated water, which will then be recycled (see photograph). This will reduce significantly the thermal loading of Biscayne Bay in the vicinity of Turkey Point.

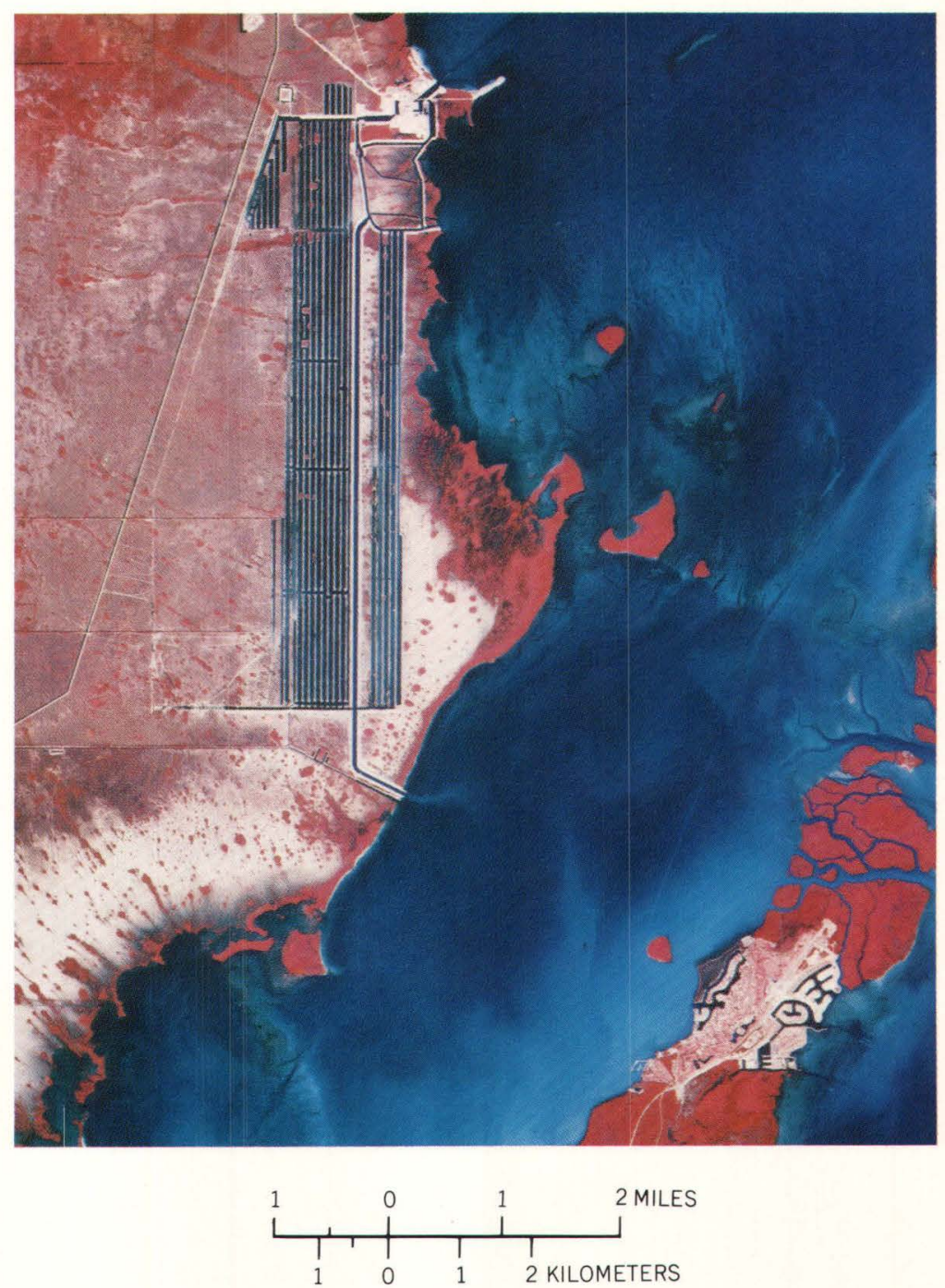

The extensive system of canals is used to cool water from the nuclear power plant at Turkey Point.

\section{Air Pollution and Meteorological Conditions in Dade County}

Air in south Dade County becomes polluted when certain meteorologic conditions occur simultaneously with gasoline engine exhaust and smoke from Everglades fire, dump fires, and burning of sugar cane at Lake Okeechobee. Such incidents occurred in July 1970, April 1971, and May 1972.

In the past, it was generally assumed that because of prevailing sea breezes, Dade County's air had an unlimited potential for dispersing airborne pollutants. Daily observations during the past 10 years indicate that haze is slowly increasing. 


\section{ENVIRONMENTAL QUALITY}

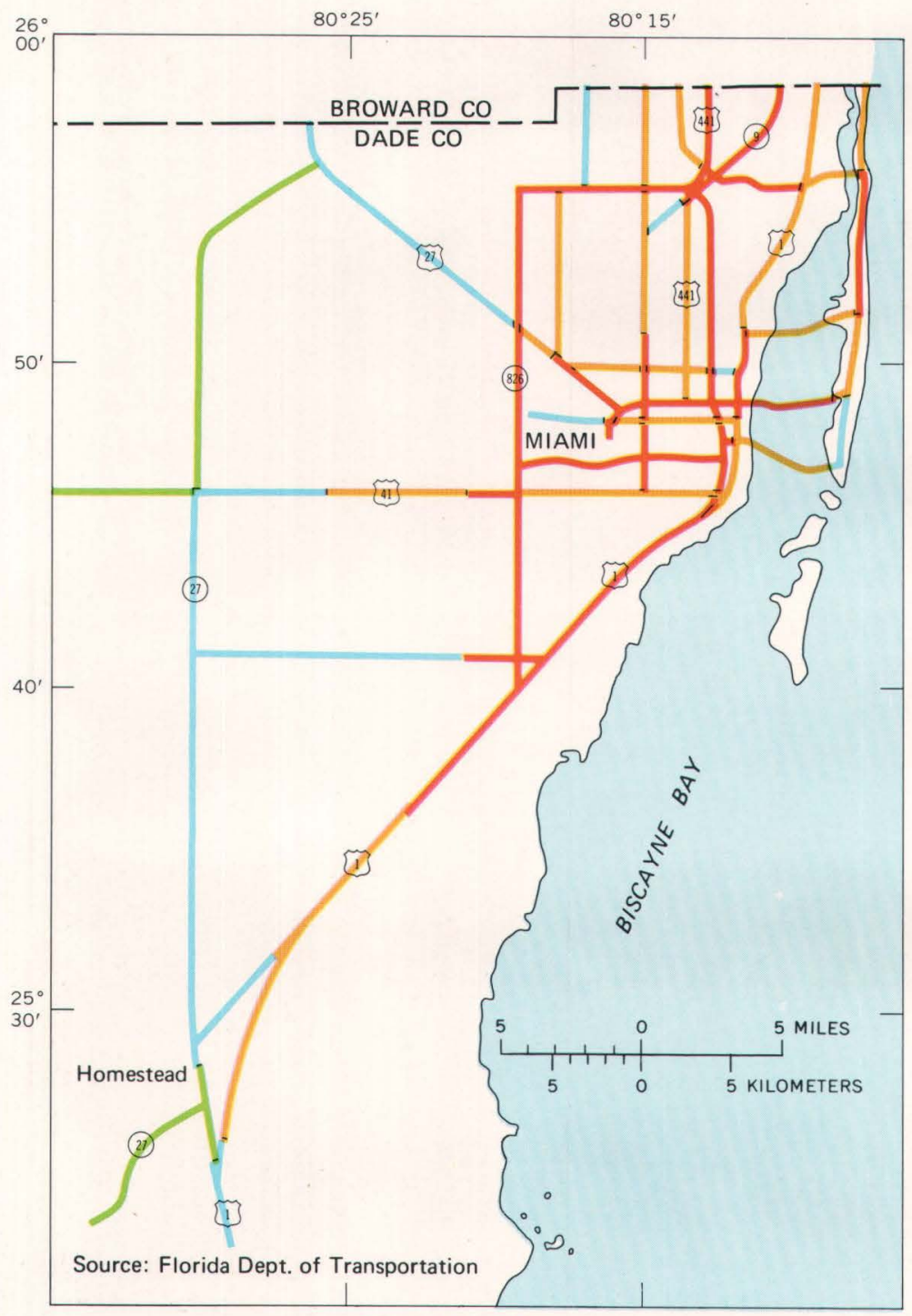

EXPLANATION

AVERAGE DAILY 1971 TRAFFIC FLOW

1000-4999 $\quad 5000-14,999 \quad 15, \overline{000-29,999} \quad 30,0 \overline{00 \text { and }}$ over

The major source of air pollution is the automobile. Increased traffic will cause increased deterioration of air quality in south Dade.
This increase is due to the increase in motor vehicles as well as the expanding industrial activities. About 80 percent of the 950,000 tons of pollutants emitted to the air in 1971 was from motor vehicles; the remainder came from industrial and commercial sources, mainly fuel combustion for heat and power generation, incineration, and open fires.

In general, the concentration of pollutants in air over Dade County is less than that over other large metropolitan areas. However, the significant increase in oxidants, oxides of nitrogen, and sulfur dioxide and a possible increase in airborne lead near expressways in 1972 indicate a deteriorating air quality.

\section{Waste Management}

In 1970 each person in south Dade County generated about one ton of solid waste and about 40,000 gallons of liquid waste. Disposal of these wastes is both complex and costly.

\section{Liquid Waste}

The liquid waste-45 million gallons of sewage per day-is disposed of primarily through drainfields and ocean outfalls. About 32 percent of the population of Dade County is served by more than 172,000 individual septic tanks. Most of these are in the south Dade area. As a result, much of the shallow ground water underlying the urbanized area has been contaminated, especially by nitrates. Recent studies, however, have found no evidence of contamination by pathogenic viruses.

More than half of the sewage from Dade County is disposed of through three ocean outfalls. An additional 13 per cent is discharged into lakes and canals or into

More than half of the sewage from Dade County is disposed of through ocean outfalls.

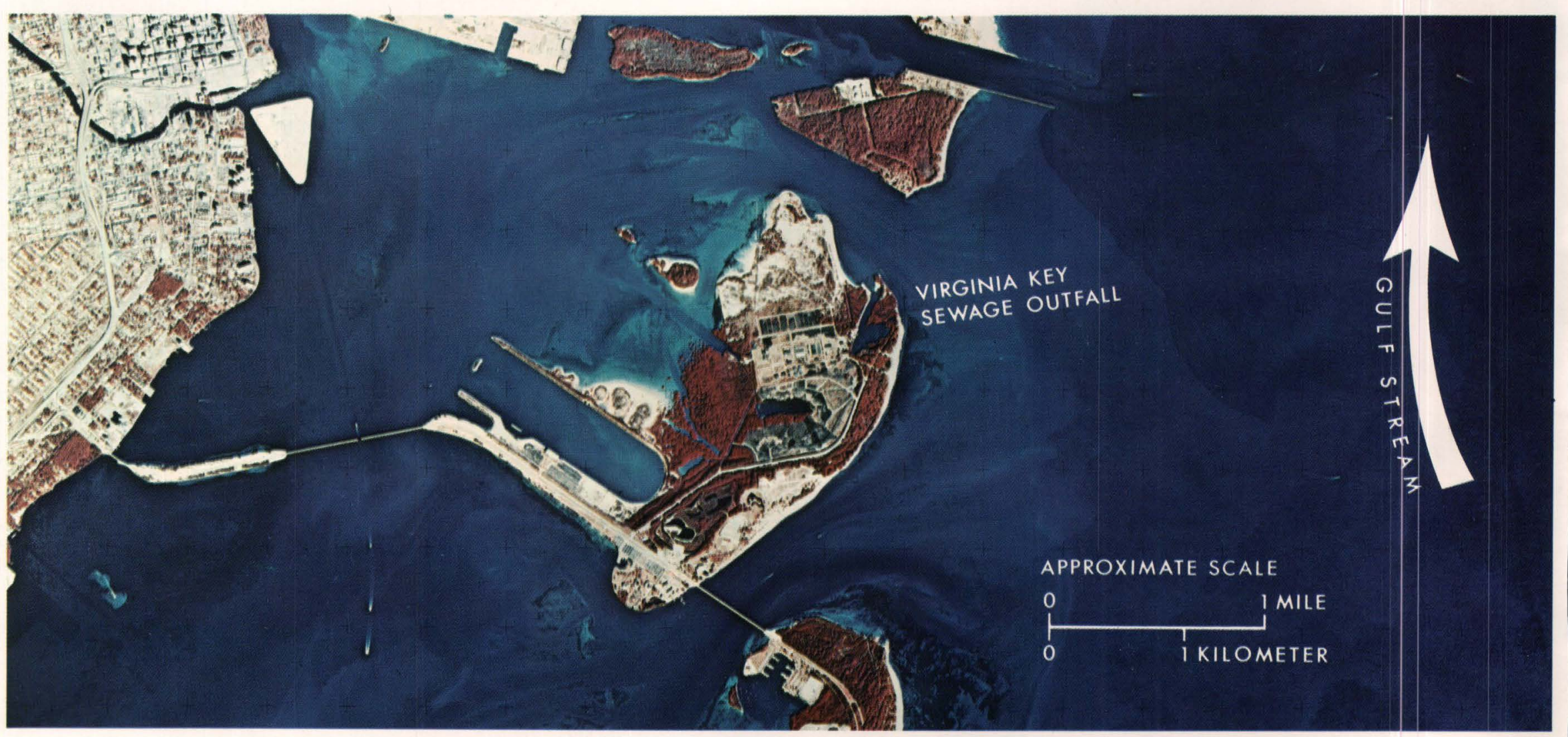




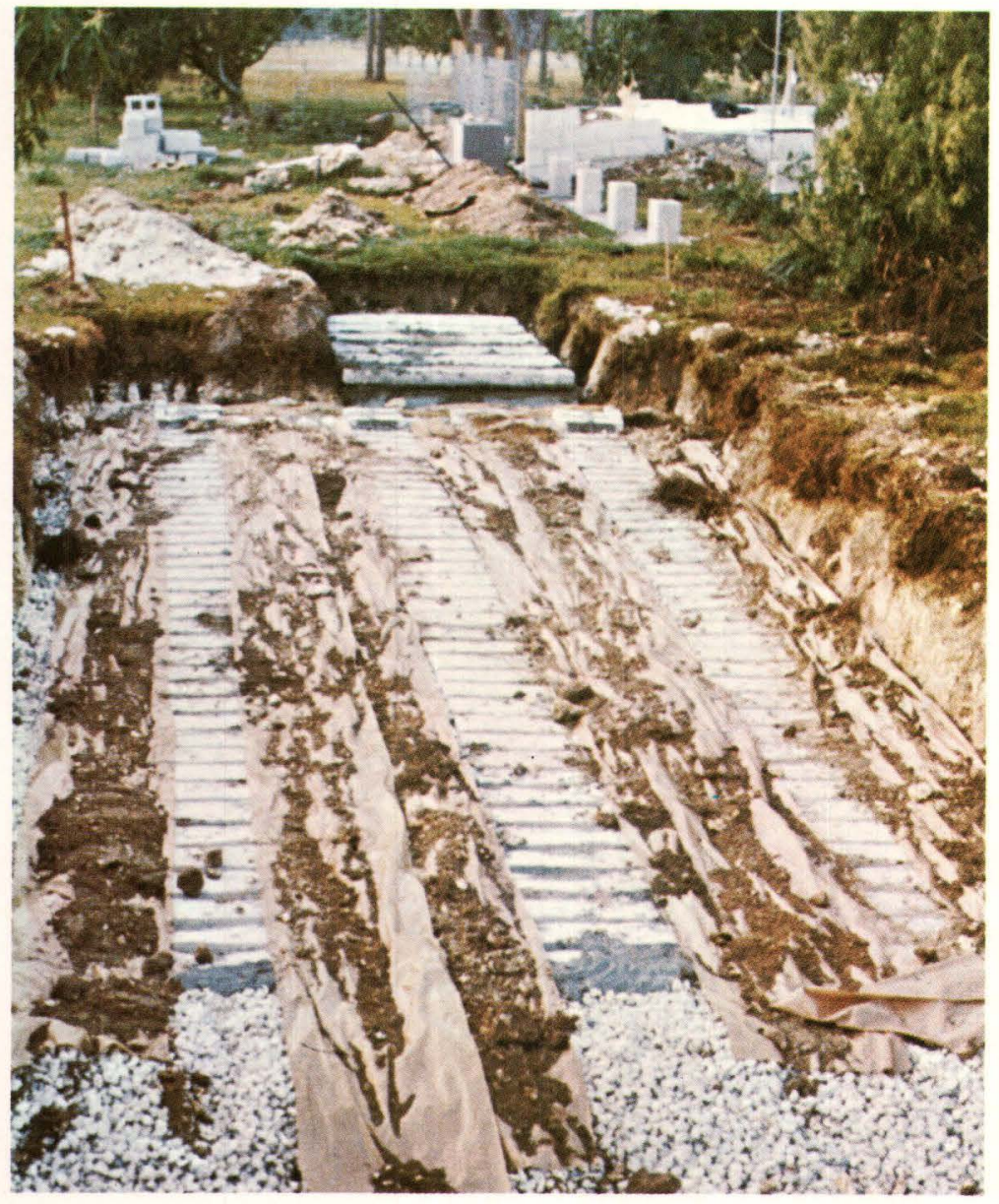

There are more than 172,000 septic tanks in Dade County. Most of these are in the south Dade area.

seepage pits. Of the 29 sewage treatment plants serving the south Dade area, only one-the Key Biscayne plant-discharges to the ocean. Two plants discharge effluent directly to the so-called "boulder zone" of the deep Floridan aquifer. Currently, about $3 \mathrm{mgd}$ of treated sewage from the Coral Gables plant and about $1.5 \mathrm{mgd}$ from the Kendall Lakes plant are being injected.

There is much controversy over the efficacy of ocean outfalls, the use of septic tanks, and the need for tertiary treatment. Deep well injection is a controversial method of waste disposal and is being carefully monitored.

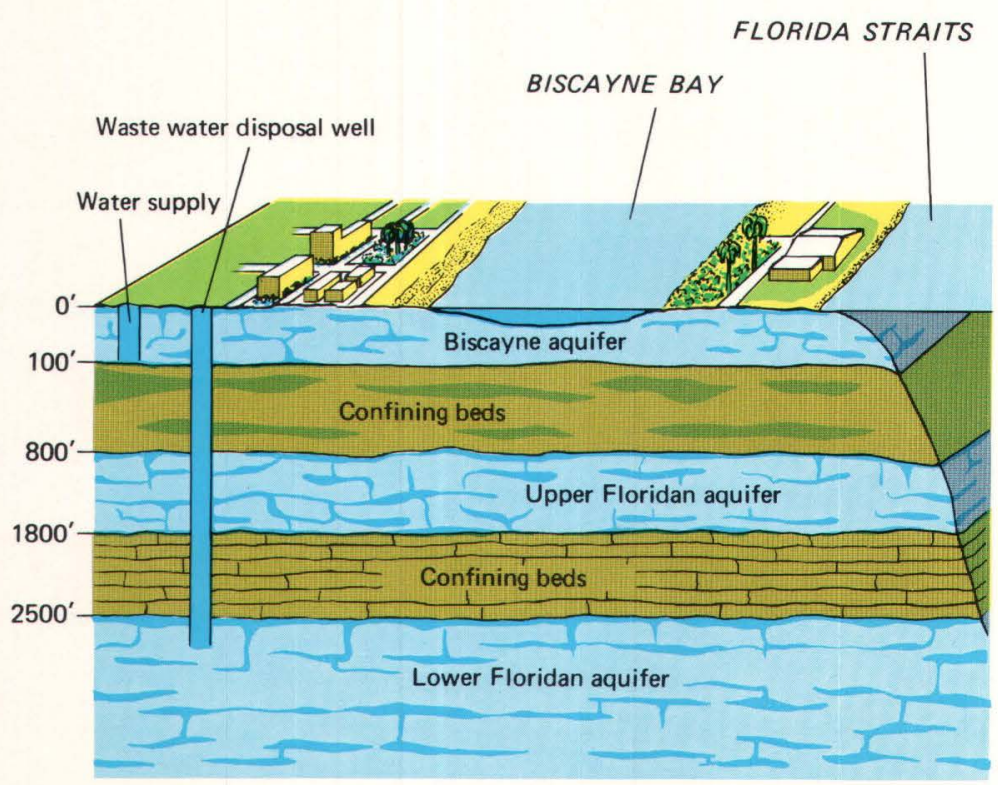

Some sewage effluent is disposed of by deep-well injection. 17

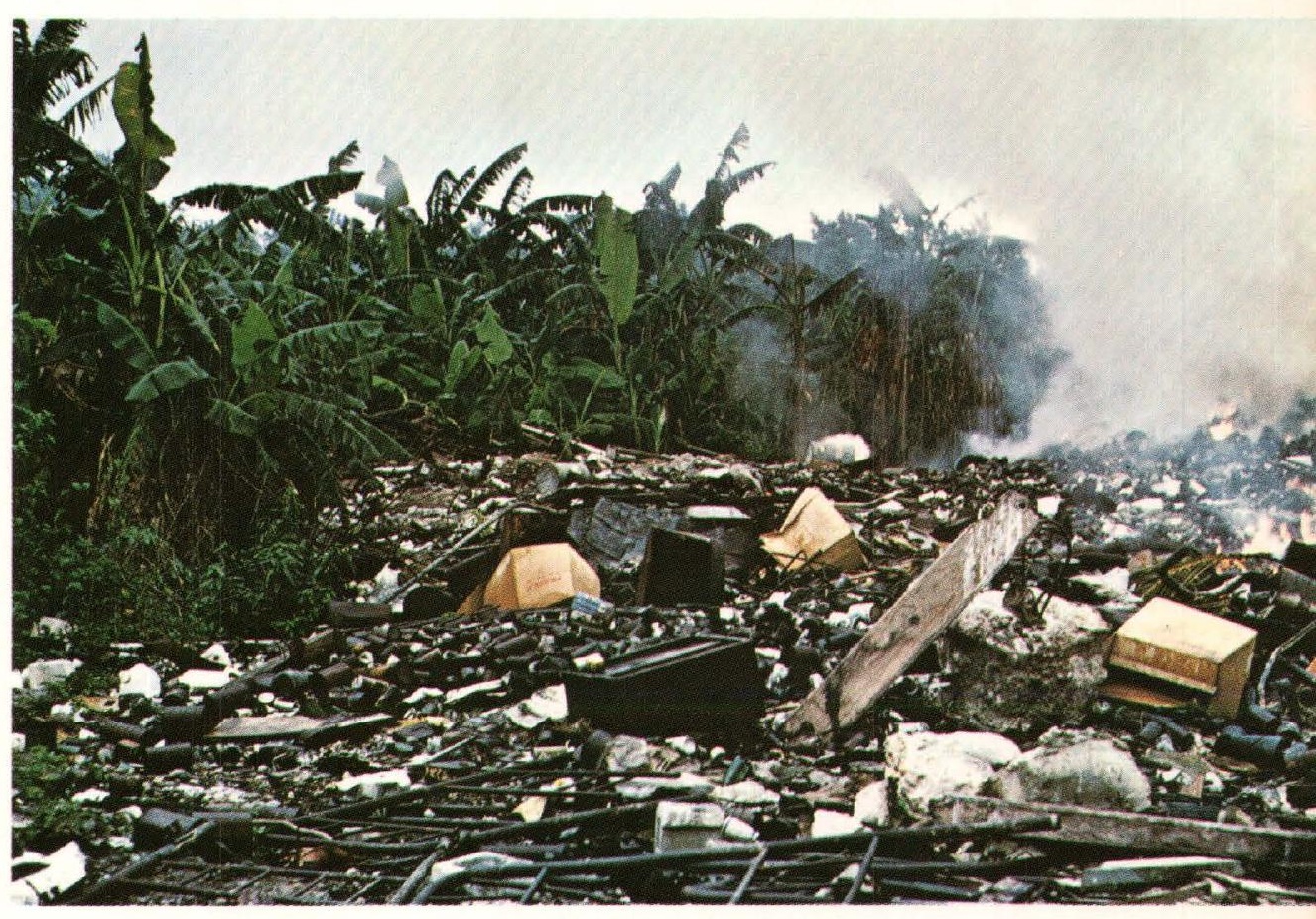

Solid wastes are disposed of in both open dumps and sanitary landfills.

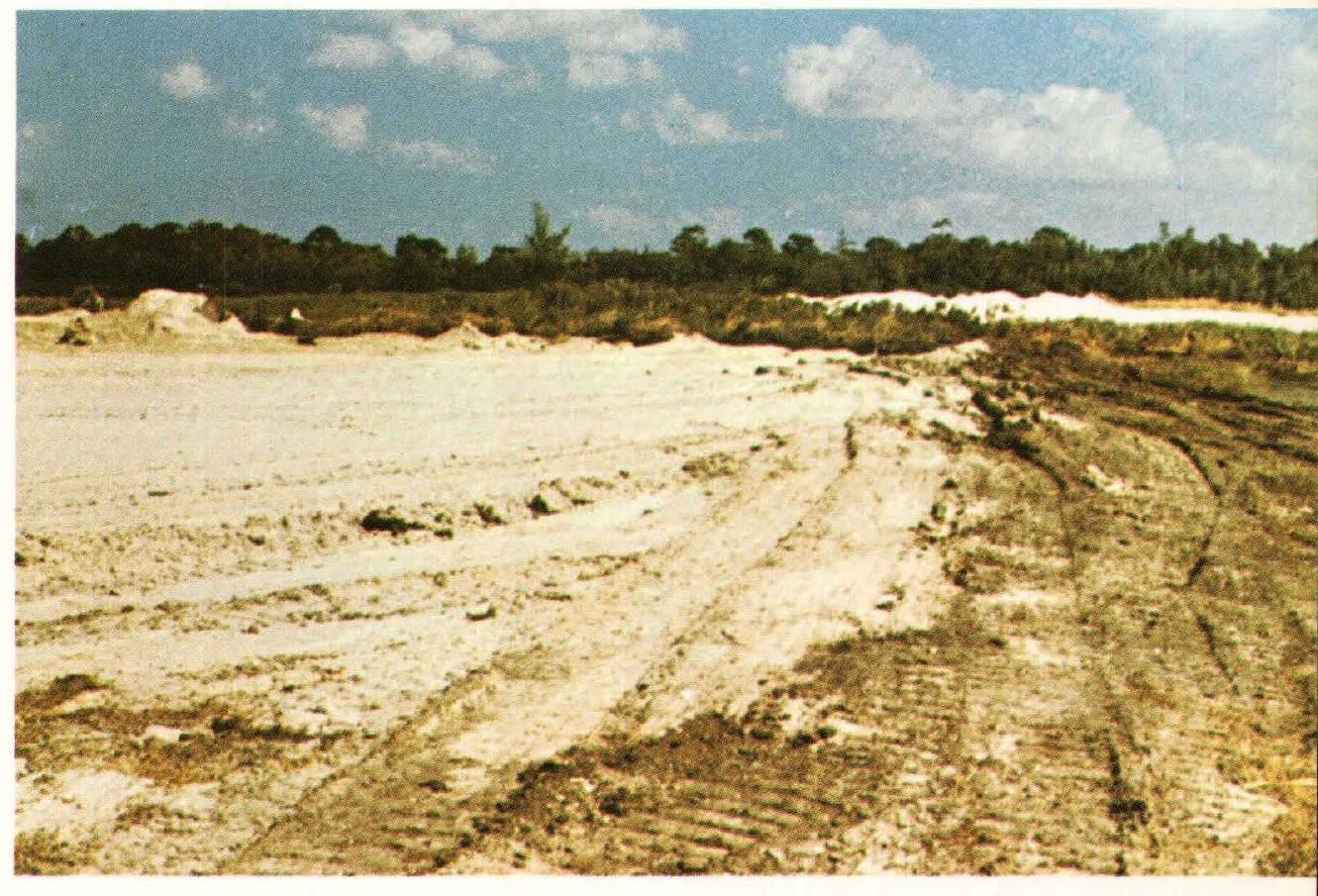

Proper operation of sanitary landfills is inhibited by thin soil and high water table. 


\section{ENVIRONMENTAL QUALITY}

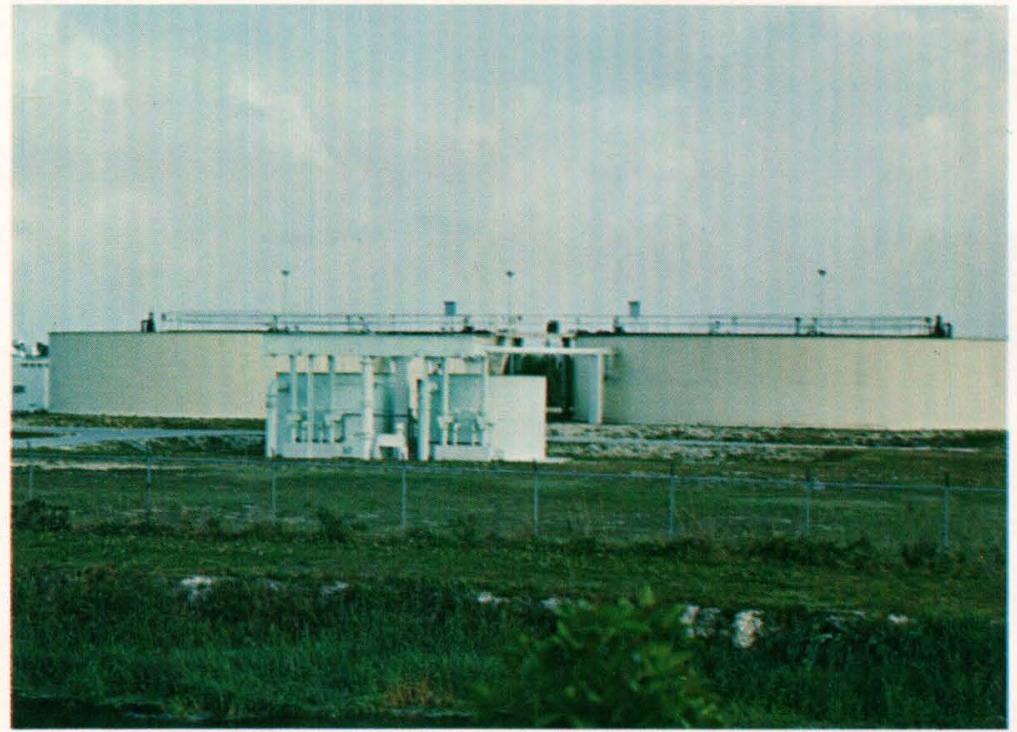

Twenty-nine sewage treatment plants serve the south Dade area.

\section{Solid Waste}

In 1970 , about 30 percent of the 400,000 tons of solid wastes generated in the south Dade area was incinerated; the rest was disposed of in dumps and landfills, mostly outside of the area. There are 18 dumps and landfills in Dade County; of these, 8 are in the area. Proper operation of sanitary landfills is inhibited by the thin soil and high water table. Therefore most landfills are basically open dumps which burn periodically and are eventually covered with a veneer soil. They are sources of pollution to the Biscayne aquifer as the heavy rainfall leaches contaminants from the wastes and transports them through the permeable limestone to the water table.

At the present time, Dade County does not have any formal recycling projects. One pilot project, however, in Coconut Grove is aimed at reducing the volume of solid waste by composting. Citizens' efforts, mostly under auspices of local conservation groups, have been limited and sporadic.

\section{Population Density and Environmental Quality}

The quality of the environment of Dade County has been significantly affected by rapid growth in population. The population of the county increased $2 \frac{1}{2}$ times between 1950 and 1970. Although tax revenues increased more than 10 -fold during this time the environment has been degraded despite the increased tax revenue. Projected population estimates indicate that rapid growth will continue into the next century. Because the south Dade area has a relatively large amount of undeveloped land, it has great potential for additional development.

The Metropolitan Dade County Planning Department has embarked on a project to reevaluate and update its General Land Use Master Plan of 1965. The new plan 18 will include specific development proposals for a mediumrange period of 10 years and general proposals for a longterm period through the year 2000 . The plan will include proposals in six broad areas: (1) land use; (2) the economy; (3) population; (4) services; (5) the environment, and (6) implementation. The new plan is scheduled for completion at the end of 1973.

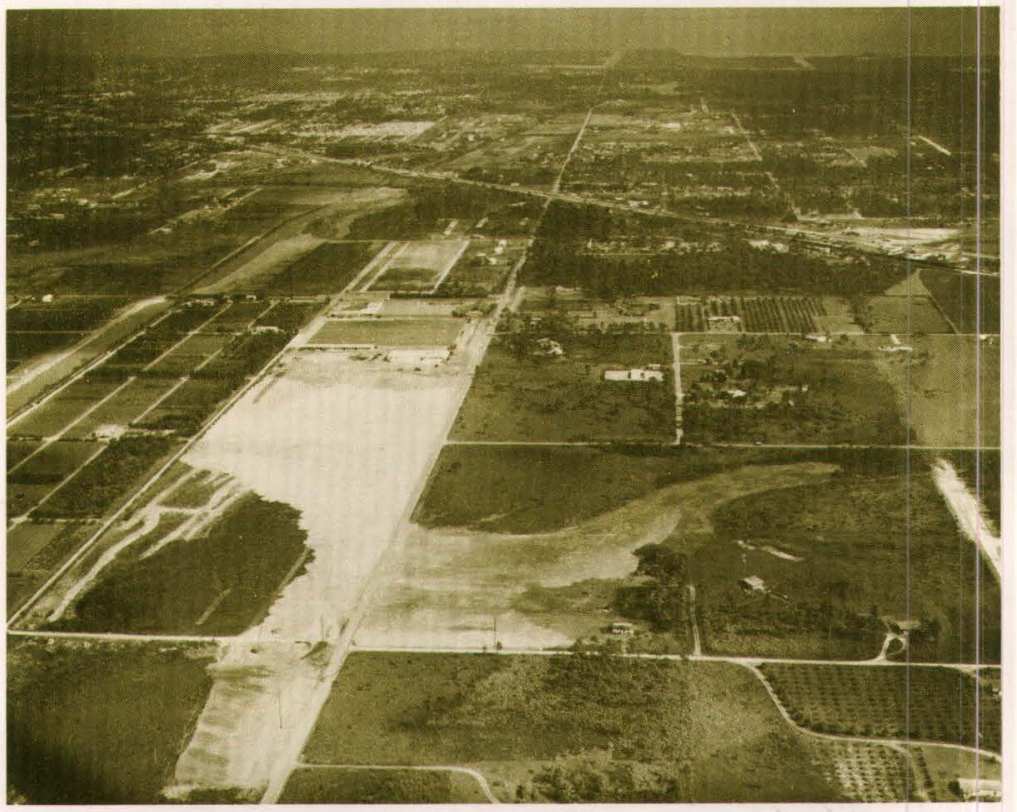

1955

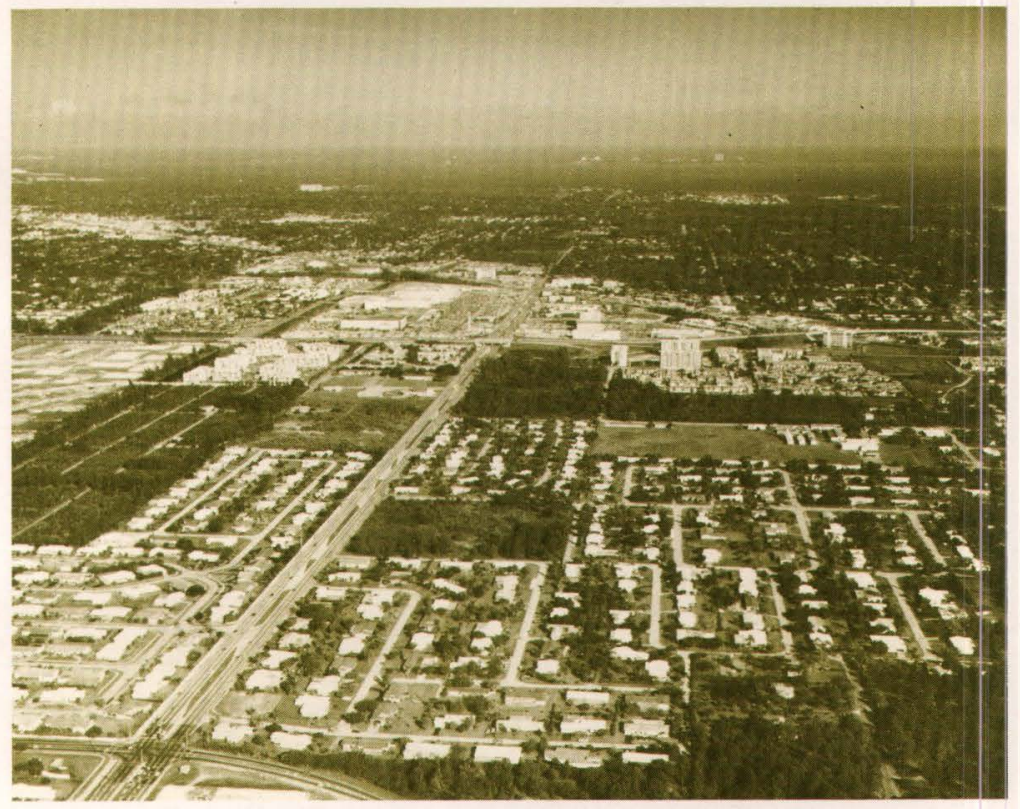

1972

The Kendall area of south Dade County exemplifies the rapid growth rate of the area over the past 20 years. 
ERTS I FALSE COLOR IMAGE

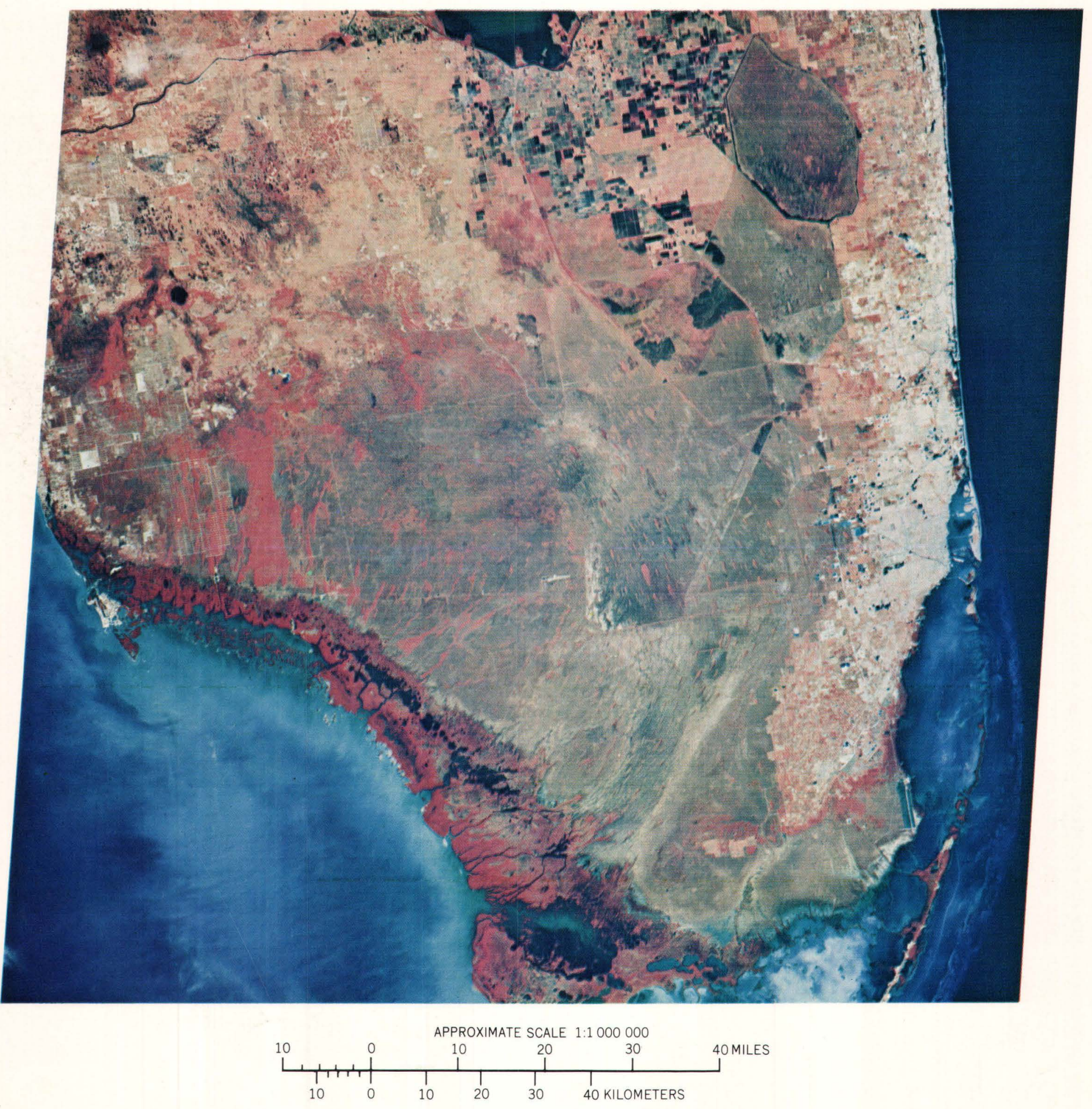

Many aspects of the environmental quality of southeast Florida can be monitored by studying earth satellite images taken at intervals of 18 days. Cloud cover permitting, it is possible to assess hydrologic conditions in the Everglades, the health of forest vegetation, possible infestation of agricultural areas, damage due to storms or hurricanes, change in urban growth, and the clarity and turbidity of coastal waters. 


\section{OUTDOOR RECREATION}

Dade County outdoor recreation participation in 1970 was estimated to be $161,558,700$ activity occasions (participation in a single outdoor recreation activity by one person during one calendar day). These included water-dependent activities (swimming, fishing, boating, surfing, etc.), landbased activities (camping, picnicking, nature study, hunting, etc.) and outdoor games and sports (baseball, shuffleboard, golf, tennis, etc.). Projected participation in the year 2000 is $339,400,000$ activity occasions, more than double that of today. In $1970,81 \%$ of all recreation activity occasions were water related (water dependent and water enhanced). This percentage is expected to increase

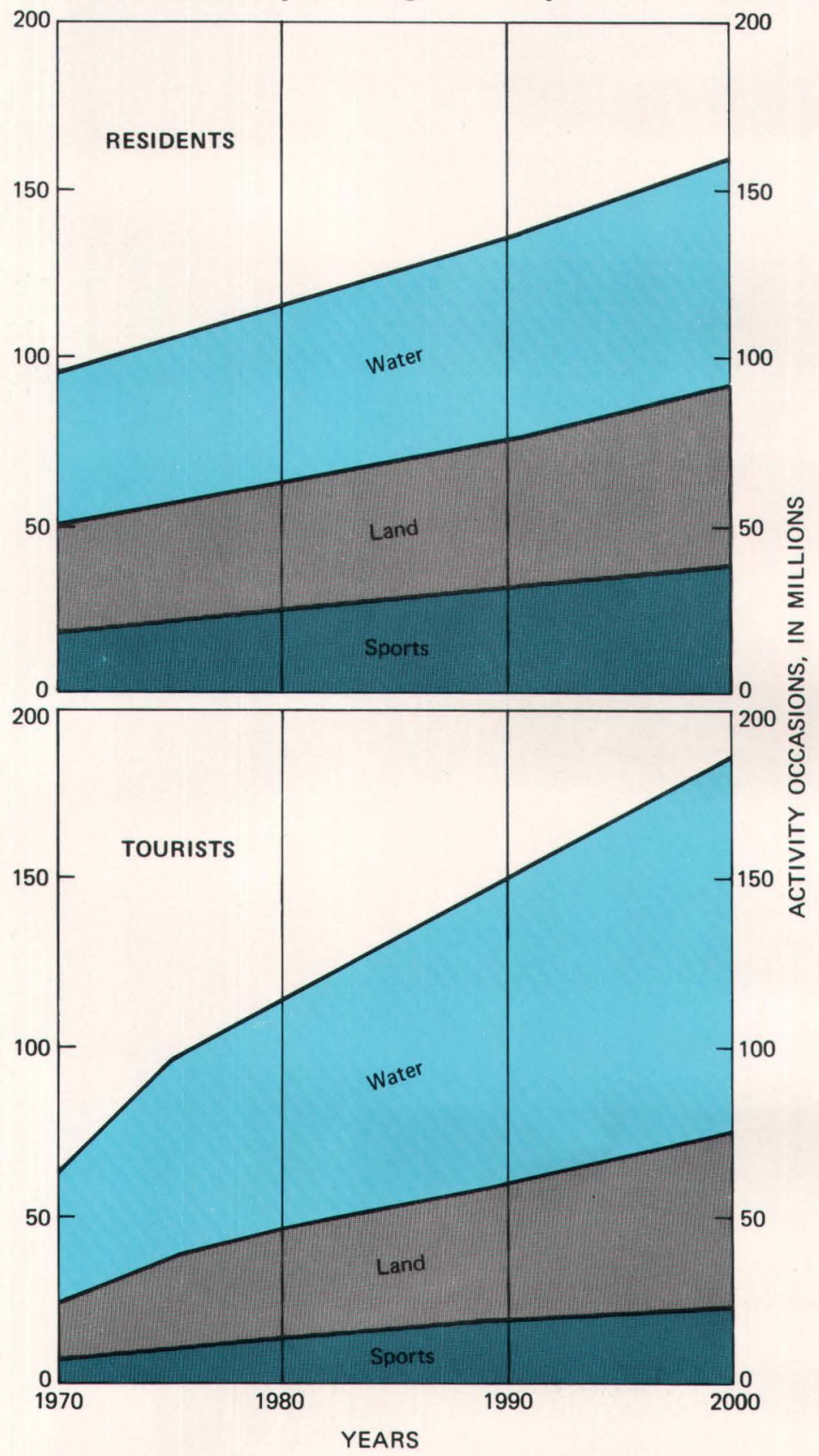

Participation in outdoor recreation activities is projected to more than double by the year 2000 .

\section{RESIDENT AND TOURIST ACTIVITY OCCASIONS} (MILLIONS)

\begin{tabular}{ccrcc}
\hline YEAR & SPORTS & LAND & WATER & TOTAL \\
\hline 1970 & 28.0 & 50.8 & 82.8 & 161.6 \\
1975 & 34.1 & 63.7 & 106.8 & 204.6 \\
1980 & 37.7 & 70.9 & 119.7 & 228.3 \\
1990 & 47.2 & 88.1 & 148.5 & 283.8 \\
2000 & 57.2 & 104.6 & 177.6 & 339.4
\end{tabular}

slightly by the year 2000 . These projections were prepared for the South Florida Ecological Study 1 / using data of the State Division of Recreation and Parks.

Current observed pressures on the area's recreation facilities, and projections (see graphs below) indicate that Dade County's recreation facilities will require expansion. For use in planning for that expansion, additional technical data will soon be available from a one-year on-site recreation participation study, the results of which are currently under analysis by the Central and Southern Florida Flood Control District.
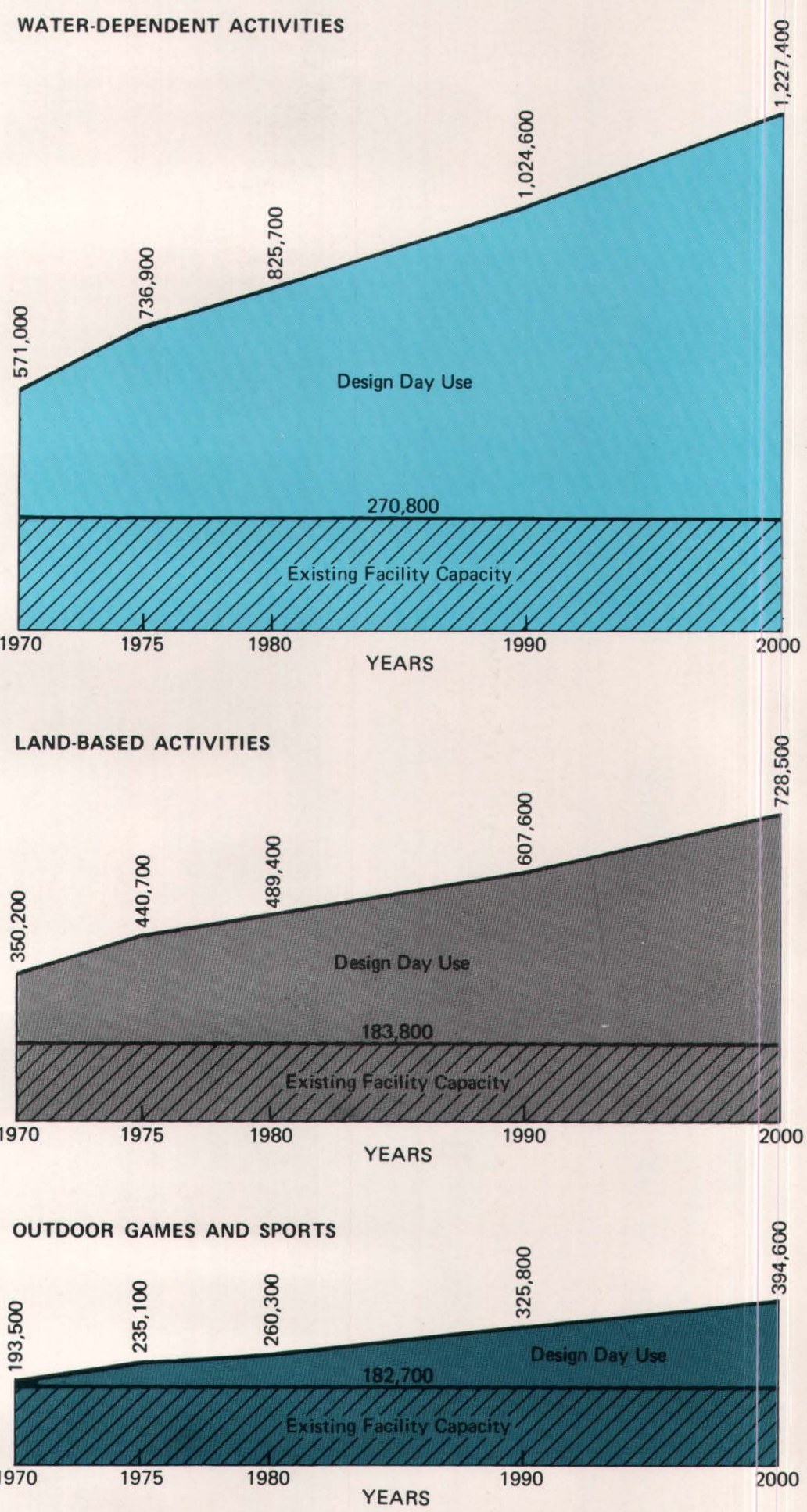

The above graphs of design day participation* for water dependent and land based activities and for outdoor games and sports indicate that design day use in 1970 was about two times greater than the rated capacity of existing facilities. Estimated future participation will require large expansion of Dade County's recreation facilities.

*Design day is computed as the average participation on Sunday during the month of second highest total recorded attendance. 


\section{Existing and Proposed Parks}

In 1970, south Dade County had a population of about 417,800 people, 33 percent of the county's population. It has 42 percent of the neighborhood and community park space, 83 percent of the metropolitan park space, 70 percent of the regional park space, and 70 percent of the natural area open space. Most of south Biscayne Bay is either in Biscavne National Monument or in the Aquatic Preserve proclaimed by the State.

National Recreation and Park Association open space standards generally recommend 5 acres of neighborhood and community parks, 5 acres of metropolitan parks, and 20 acres of regional parks per 1,000 population. Dade County's open

PROJECTED PARK AND OPEN SPACE NEEDS, IN ACRES

\begin{tabular}{|c|c|c|c|}
\hline 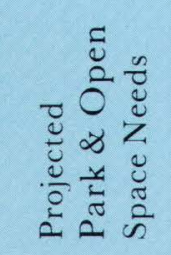 & 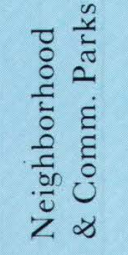 & 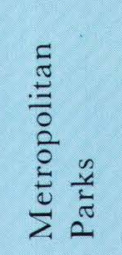 & 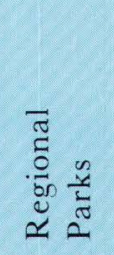 \\
\hline $\begin{array}{c}\text { Available } \\
1975 \\
1980 \\
1999 \\
2000\end{array}$ & $\begin{array}{r}2,694 \\
7,022 \\
7,580 \\
9,334 \\
11,231\end{array}$ & $\begin{array}{r}6,873 \\
10,074 \\
11,264 \\
14,280 \\
17,440\end{array}$ & $\begin{array}{r}4,294 \\
40,296 \\
45,055 \\
57,119 \\
69,757\end{array}$ \\
\hline
\end{tabular}

PARK LAND, IN ACRES

\begin{tabular}{l|r|r|r}
\hline \multicolumn{1}{c|}{ Park Land } & \multicolumn{1}{|c|}{$\begin{array}{c}\text { Dade } \\
\text { Total }\end{array}$} & \multicolumn{1}{|c}{$\begin{array}{c}\text { South } \\
\text { Dade }\end{array}$} & $\begin{array}{c}\text { \% of } \\
\text { Total }\end{array}$ \\
\hline Neighborhood & & & \\
\& Community & 2,694 & 1,127 & 42 \\
Metropolitan & 6,873 & 5,738 & 83 \\
Regional & 4,294 & 3,000 & 70 \\
Natural Areas & 725,400 & 510,994 & 70
\end{tabular}

Study shows that Dade County parks and open-space areas need to be expanded. Specific needs have been computed based on the projected resident population plus an estimated "tourist population" and National Recreation and Park Association Open Space Standards. Regional park needs may be partly met from use of the large natural area reserve and large parks in adjacent counties.

space plans set a standard for 4.5 acres of neighborhood, community, and related space per 1,000 population but no standards relative to other park types. The most densely settled areas of Dade County have been identified in the Metropolitan Dade County Community Improvement Program report of the County Manager. These are prime areas for consideration for neighborhood and community park expansion. Additional county actions (planning, land-use controls, ordinances) are needed to assure adequate internal open space in newly urbanizing areas.
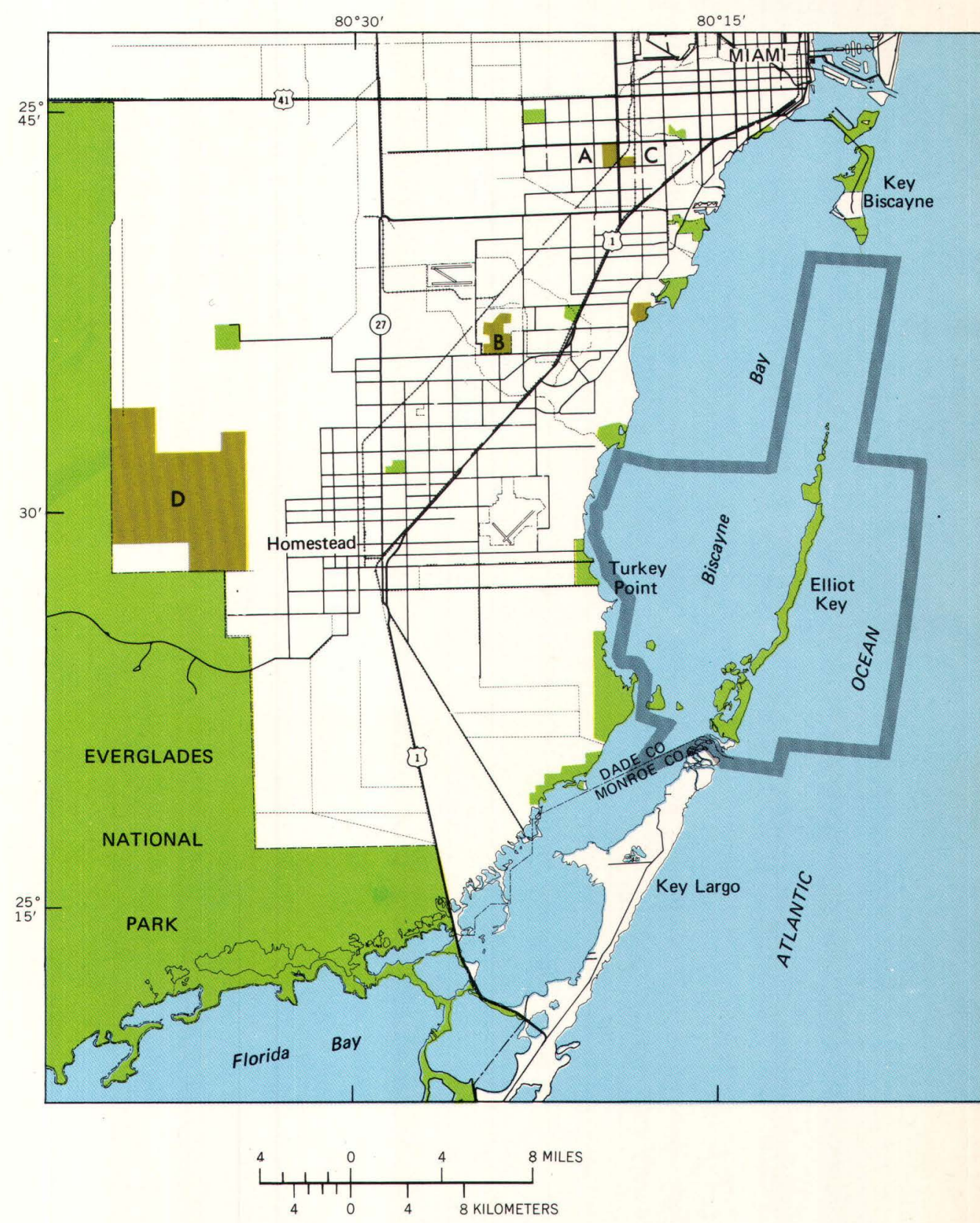

EXPLANATION

PARK AND OTHER RECREATION AREAS

(100 acres or larger)

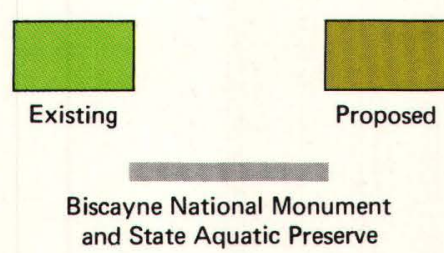

Most of the parks in the area are water oriented.

The 1972 bond issue program will permit needed expansion of the metropolitan park system. New area sites of significance to south Dade County include Tropical Park Sports Complex (A, see map), Richmond Zoological Park (B), and Miller Lake Park (C). The 25,000 acre Aerojet tract (D) is being considered for a large regional park.

Looking to the future, park and recreation planners are faced not only with keeping pace with growth in the area but making up for deficits in recreation facilities in other parts of the county as well. South Biscayne Bay and the still undeveloped shoreline areas represent the county's most important natural resource potential for meeting these recreation needs. 


\section{Waterfront Recreation Development}

The urbanization of Dade County is producing conditions of critical stress on the marine ecosytems of south Biscayne Bay. In fact, most of this part of the bay was closed to recreation use for part of March 1973 due to algae/pollution conditions. Increasing recreational use of Biscayne Bay and adjacent shoreland will inevitably add to the stress on the ecosystems of those areas. In designing new parks for the area, minimization of impact on natural environments will be a matter of major concern.

\section{Mangrove Zone}

The mangrove forest along the south Biscayne Bay shoreline produces leaf debris which is at the bottom of the marine food chain, and the mangrove roots provide refuge for many marine organisms. The roots also stabilize the shoreline, reduce storm tide damage, and filter upland runoff. From

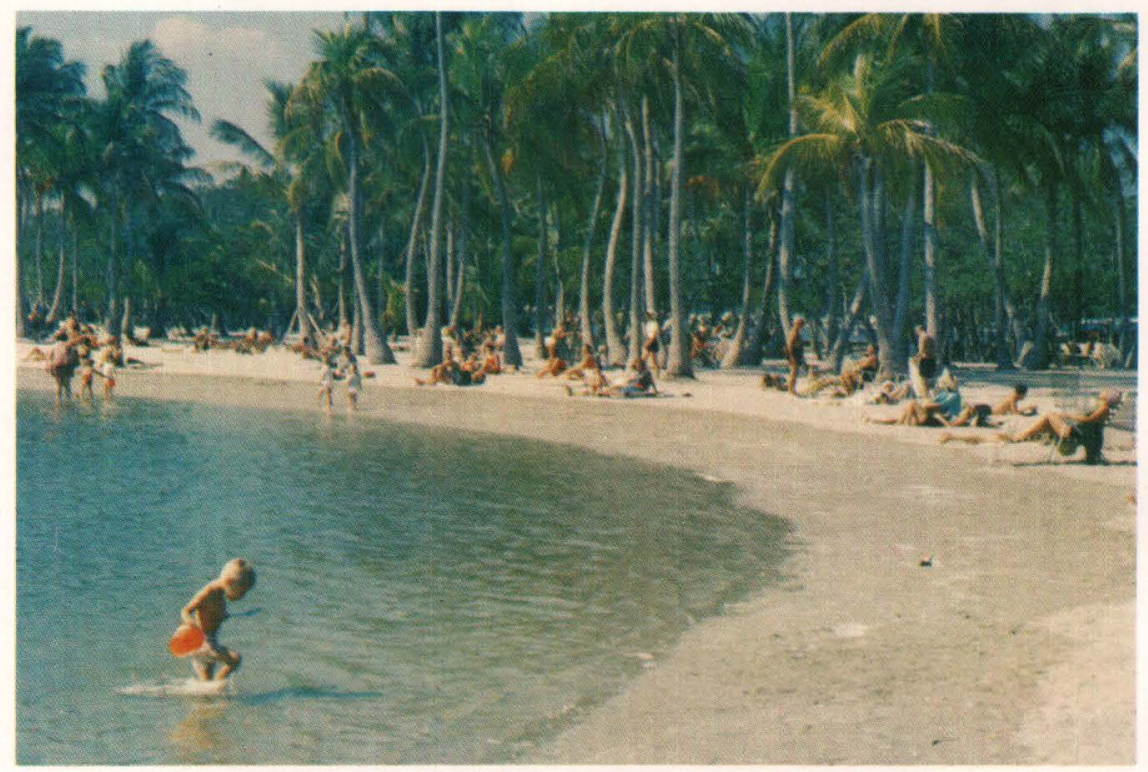

Atoll pools provide bathing facilities inland from the coast.

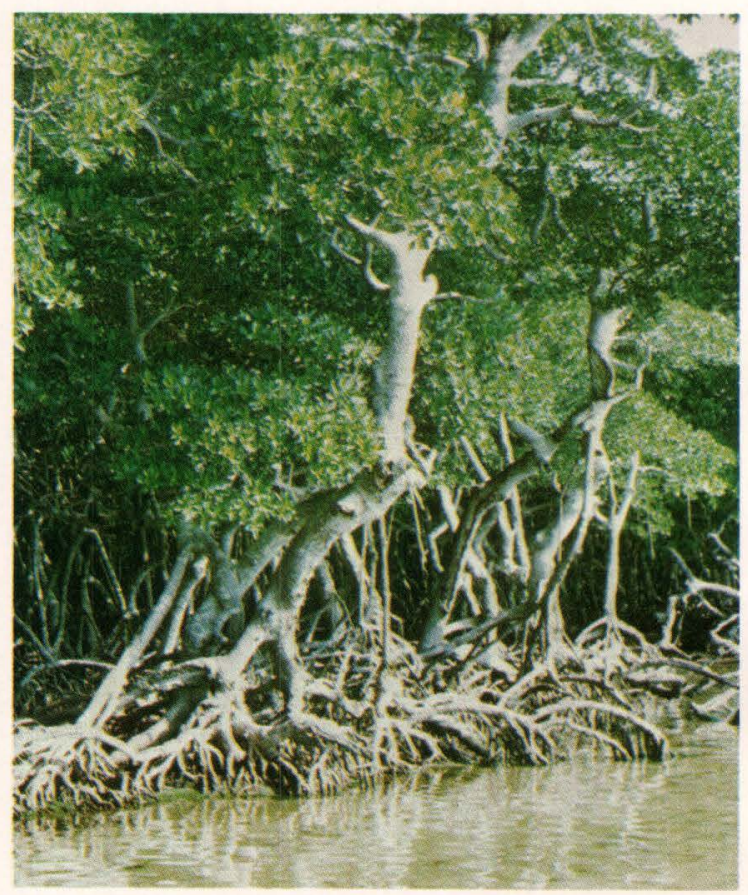

The mangrove fringe provides food for many aquatic species. a recreation standpoint, the mangrove fringe restricts visual and physical access to the bay. It is not suitable for direct recreation use except for limited nature study potential yet needs preservation to help maintain water clarity, quality, and marine productivity.

\section{Swimming}

Natural swimming beaches are few in south Biscayne Bay. To provide needed swimming opportunities, atoll pools or swimming lagoons have been excavated at some south Dade County parks just inland from the bay. An alternative to be considered in meeting future needs would be the development of either fresh-or salt-water swimming pools at inland sites rather than in the primary mangrove fringe.

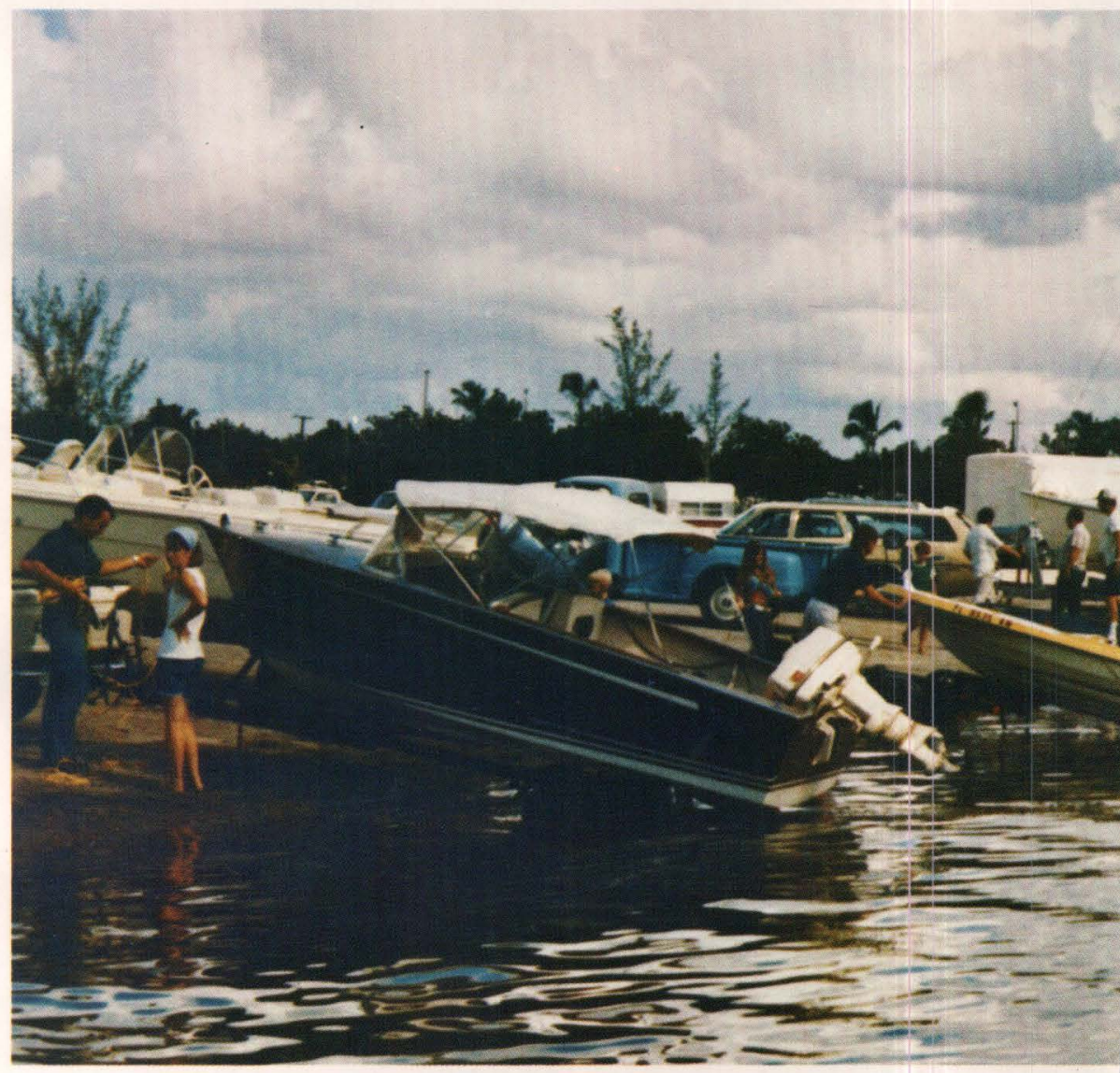

Existing marine facilities are jammed to capacity.

\section{Boating}

Existing marine facilities are crowded. There are several possible actions which could be considered for alleviating this condition and also for minimizing environmental impacts such as impingement on the mangrove zone and seepage of fresh water to Biscayne Bay. Some of these alternatives are:

1. a master plan for marina development in Biscayne Bay, covering additional boat launching and storage facitities;

2. limiting dredging for needed marina development to the minimum necessary for a launching and turning basin;

3. boat docking space to be provided in dry storage lots or buildings;

4. restriction of channel dredging in the mangrove zone and productive bay bottom areas to minimum depths and widths, with tie-ins to existing channels whenever possible. 


\section{Recreation Planning and Management}

Administrative responsibility for south Biscayne Bay is divided, Biscayne National Monument being under Federal jurisdiction, the waters of the bay primarily under State jurisdiction, and coastal land use and recreational development being controlled by Dade County and various municipal governments. Coordinated planning would appear to be most important in such a situation. An example would be the coordination of plans for boating facilities in Biscayne National Monument with plans for development of mainland marine facilities, including means of berthing boats in the 30 -foot class or larger to minimize environmental impact.

The primary waterfront parks now existing along the southern mainland shoreline are Dinner Key Marina, operated by the city of Miami, and Matheson Hammock, Chapman Field, Black Point, and Homestead Bayfront Parks, operated by the Metro-Dade government. Recent bond issues passed by the city of Miami and by Dade County include funds for expansion of Dinner Key and Homestead Bayfront Parks and for design and construction at Black Point and Chapman Field, both of which are presently undeveloped.

\section{Black Point}

Dade County's plans include development of camping and picnicking areas, a swimming facility, a sailboat-paddleboat-canoe rental concession with canoe trails through the mangrove area, and possible development of a marina facility. The existing boat basin on the south side of Black Creek is privately owned and not a part of current land acquisition action. The area between Black Creek Canal and Goulds Canal appears to be better suited to intensive recreation development than the land now in county ownership. The bay bottom and adjacent mangrove zone between the Black Creek channel spoil area and Black Point is particularly shallow and productive, and consideration should be given to careful study of that area before any development is planned. County plans for camping provide for use of lands near 87 th Avenue. Consideration should be given also to the mangrove fringe as a conservation zone, with the canoe trails aligned wherever possible with the existing mangrove creek alignments.

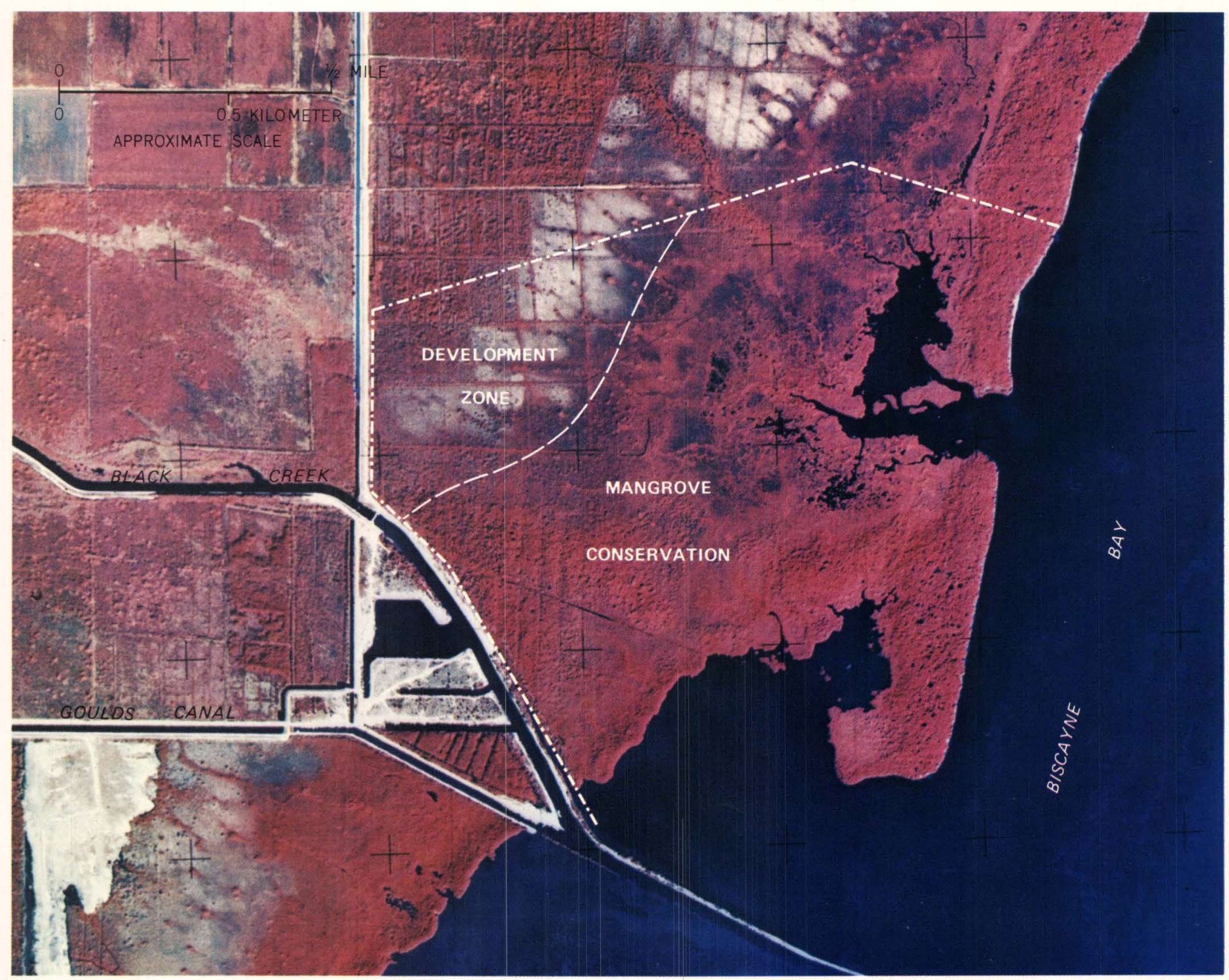




\section{Chapman Field}

Dade County plans to develop Chapman Field Park as a marina and day-use facility. The proposed marina facility would provide needed relief from the congestion at nearby Matheson Hammock Park. There are several possible development alternatives which could be accomplished with minimum environmental impact, including:

1. using the existing dredged lake in the northwestern segment of the property;

2. routing channels to Biscayne Bay through existing waterways to connect to the Florida Power and Light Channel;

3. using a large crushed rock storage area between the easternmost lake on the property and the bayfront to accommodate almost any type of well-planned day use facilities;
4. using the lake for canoes, paddle boats, or small sailboats which do not require a major boat handling facility. This would provide boating in protected waters;

5. protecting of the larger mangrove forest on Shoal Point in its natural condition;

6. providing added recreation through such facilities as boardwalk nature trails and an observation platform.

Adjacent to the Chapman Field parksite is the U.S. Department of Agriculture Plant Introduction Station. The station area has recreation potential without environmental problems. Under certain conditions, such Federal properties can be transferred to local government agencies for park and recreation purposes. The desirability of such a transfer should be considered in the future.

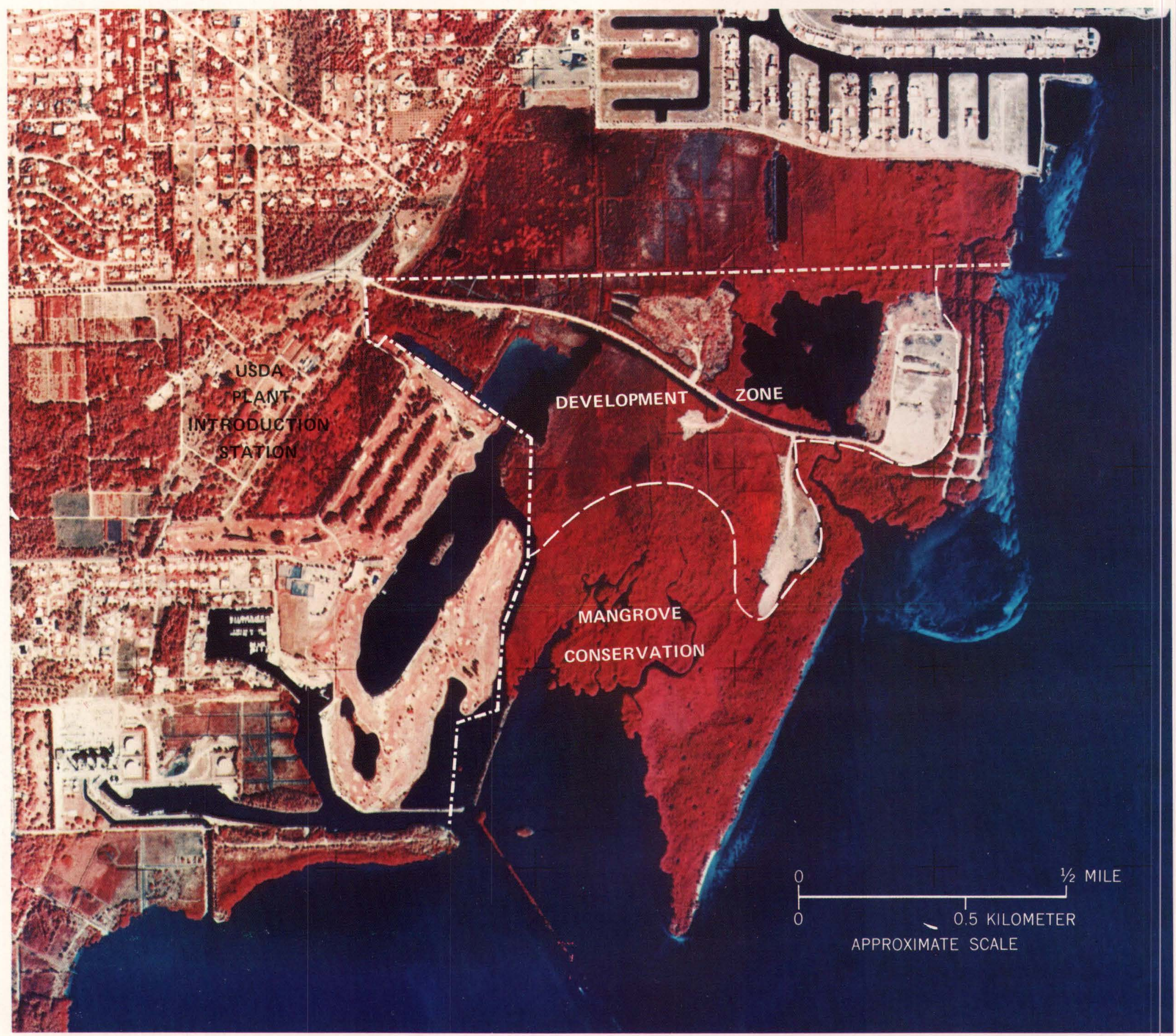

The Chapman Field recreation area also offers the opportunity for development commensurate with environmental protection. 


\section{EVERGLADES NATIONAL PARK}
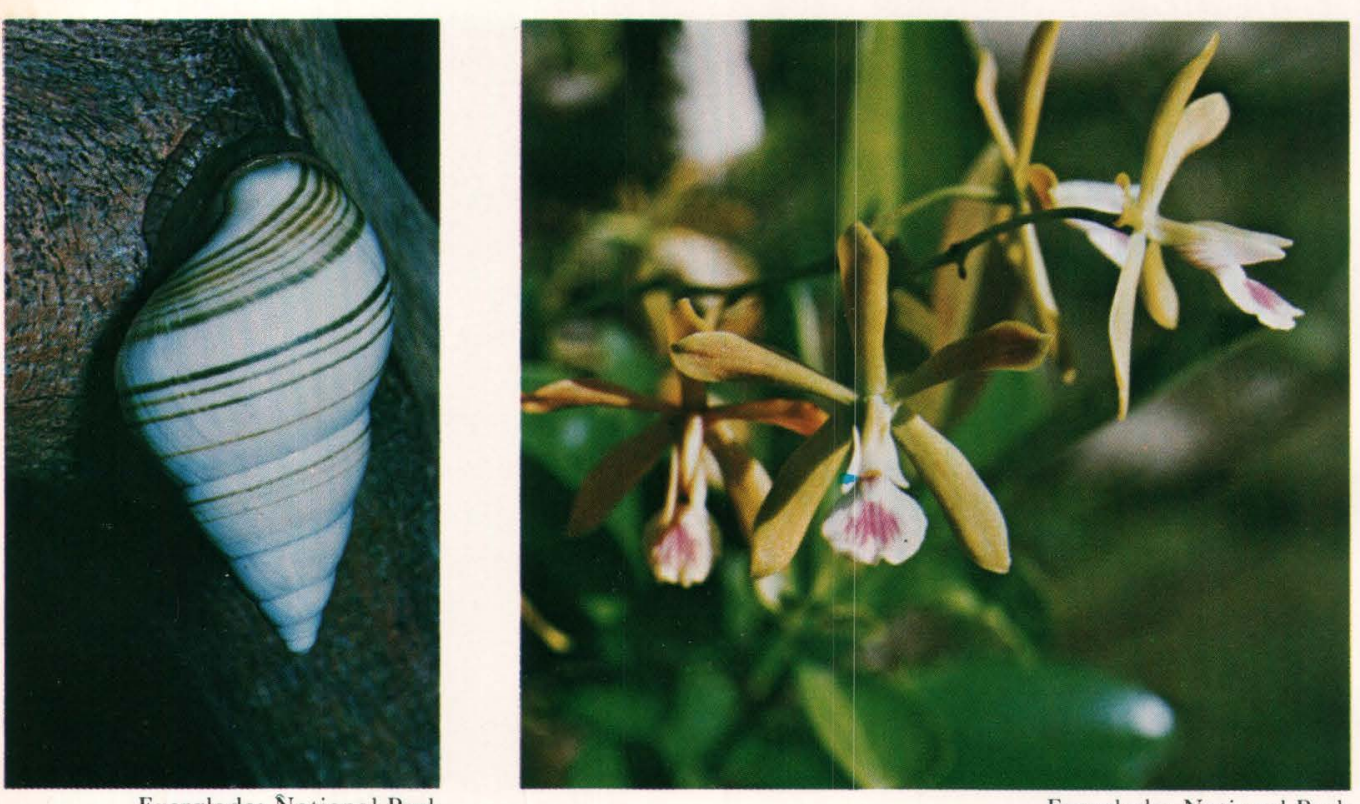

Everglades National Park

Everglades National Park
Everglades National Park provides the last large sanctuary for several species of tropical plants and small animals which occur only in southern Florida and are rapidly becoming scarce as their native habitats are cleared for agriculture and urban development.

\section{Wildlife Resources}

Just as the different kinds of plants have adapted to different water levels, so have the animals adjusted with habits or life cycles that can cope with both seasonal flood and drought. In the Everglades, fish are a critical link in the food chain. Although the habits and life cycles of the fish are not well understood, a few factors seem important. The varieties of fish living in the Everglades can survive in shallow water and often in very crowded conditions. During the dry season when the surface water recedes to small ponds and the deeper sloughs, fish congregate in these confined spaces until summer rains allow them to disperse again into the marshes and swamps. Other animals also congregate to take advantage of the concentrations of food and water.

The nesting activities of many wading birds coincide with the seasonal concentration of fish. At these times there is ample food for hungry young birds. But a severe drought that drys up the water holes and kills millions of fish, or the dislocation of a feeding ground too far away from the nesting site, jeopardizes a generation of birds. If droughts continue for several seasons an entire species or population is threatened by starvation.

During a drought, fish and birds may benefit from alligators. When the water level lowers, alligators retreat to low places in the underlying peat and by shoveling with their broad noses enlarge these holes into ponds, called "gator holes". Frequently these are the o.ly bodies of water during drought that can supply the water and food for the animal population.

The American crocodile today is limited to the coastal areas south of Biscayne Bay. Much of his or ginal habitat from north of Miami to the lower Keys has been destroyed by development, and the Park is now his only sanctuary.
Birds, both resident and seasonal, abound in the Everglades. Especially prevalent are large flocks of wading birds.

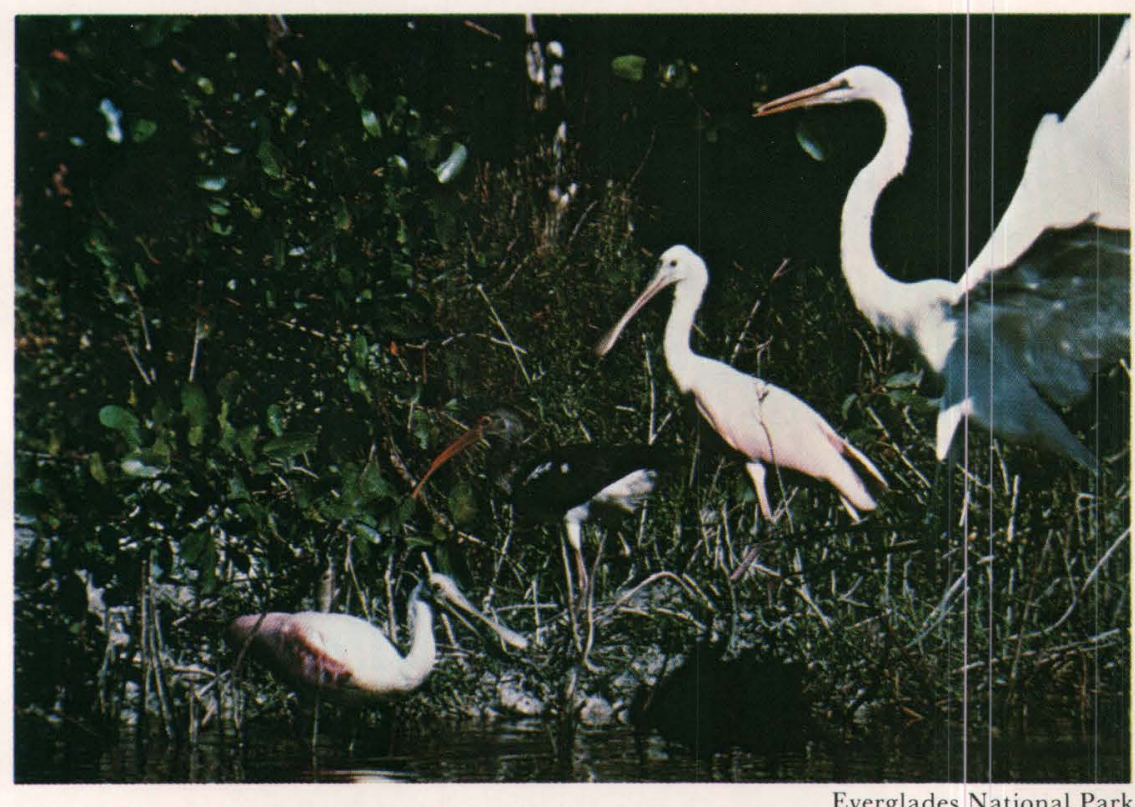

Everglades National Park

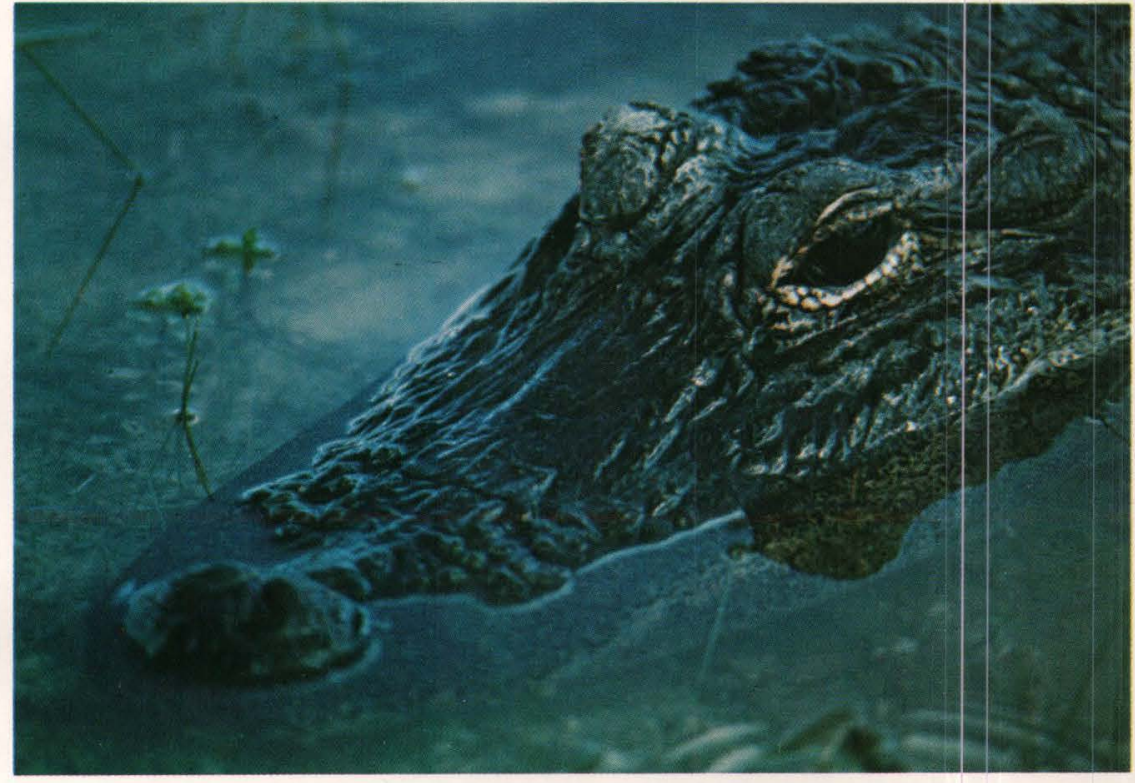

The alligator, once extensive throughout south Florida, has had its numbers and range greatly reduced by poachers and developmental pressure. They are essential, however, to the continuing life of the Everglades during the dry winter season. By clearing and maintaining water or survival holes they provide habitats necessary for fish and birds. (Photo by Barry Zuckerman)

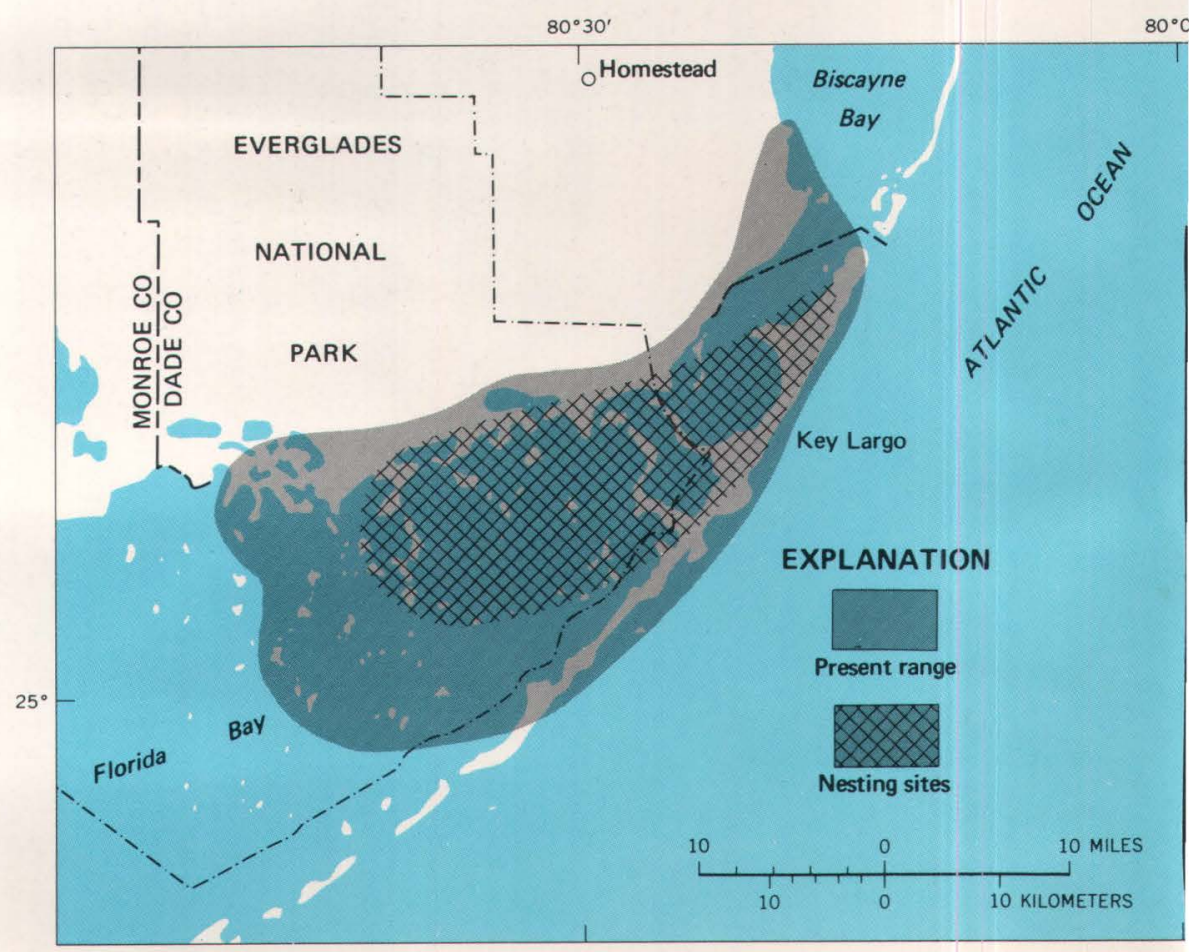




\section{Original and Altered Drainage}

Originally, water during seasons of extreme flood moved slowly from the north, down the gentle regional slope to the south. Lake Okeechobee acted as a large natural reservoir for the whole Everglades system. Excess water overflowed directly to the Atlantic, to the Gulf of Mexico, and to the Shark River Slough in the Everglades.

On each side of the Shark River Slough are equally important drainage systems. The Big Cypress Swamp, to the west, drains predominantly west and south, but contributes some water eastward toward the Shark River Slough. In the east along the coastal ridge a shallow trough, Taylor Slough, collects rain and runoff water that moves southward through breaks in the coastal ridge to Florida Bay.
These drainages act as a circulatory system for south Florida. They supply the Everglades National Park with water, which in turn carries food and nutrients to the plants and wildlife of the region. Evaporated water recirculates as rain to complete the water cycle.

Men started draining lands and farming sugar cane and rice along the south rim of Lake Okeechobee in the early 1900's. These drainage canals and subsequent ones built for flood control intercepted the overland flow of water in the area and diverted part of it to the ocean. Not only did canals drain away water, but later roads built across southern Florida diked and impounded the water. Further, during the dry season, salt water penetrated inland along the canals, threatening the underground water supply as well as the immediate lands. As a result, the flow from north to south must now be artificially maintained by means of a system of canals and large water storage basins.

Three drainages dominate the Everglades. However, the natural flow through these broad, shallow water courses has been significantly altered by networks of roads and canals and by management of the regional water system.
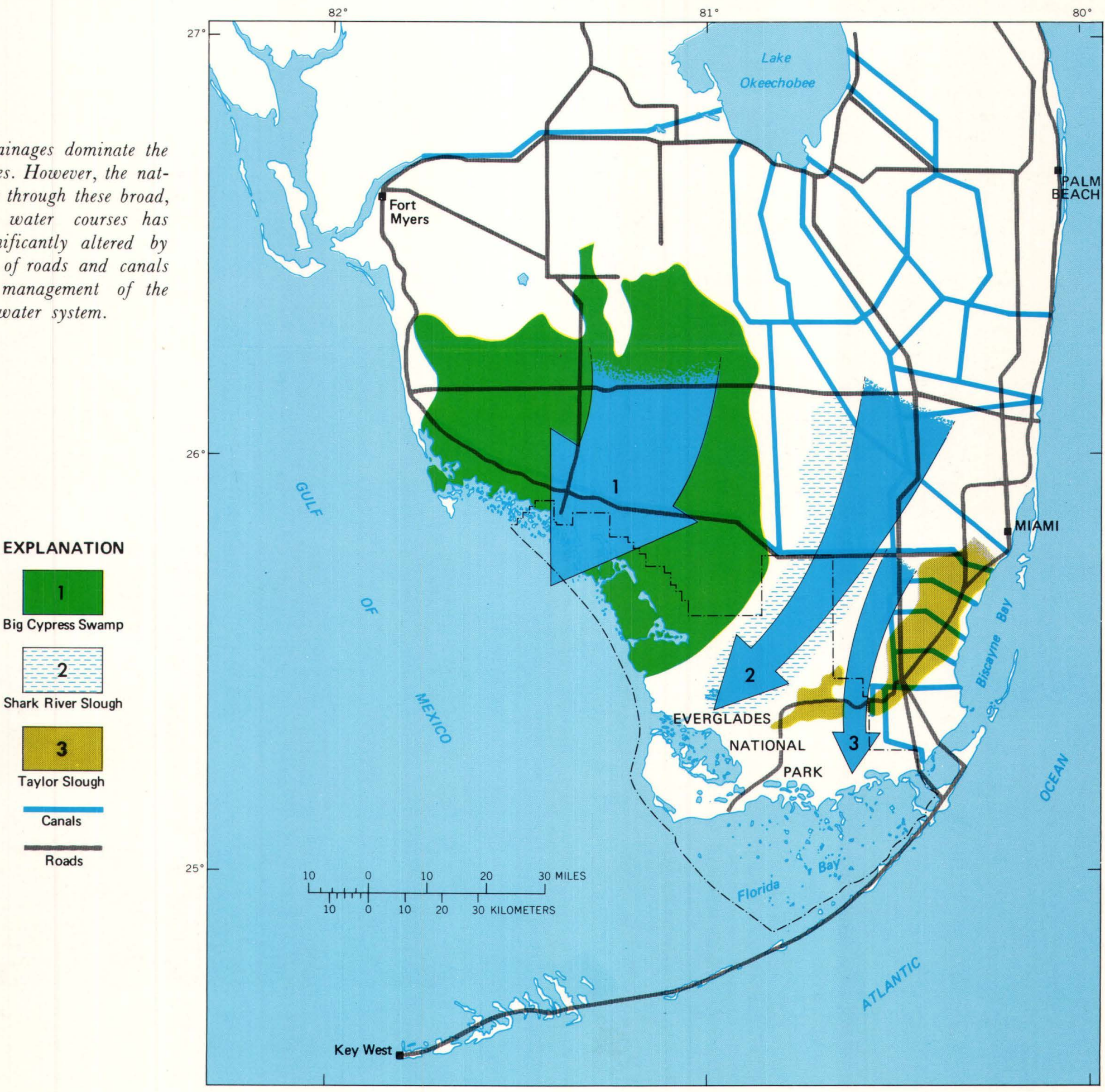

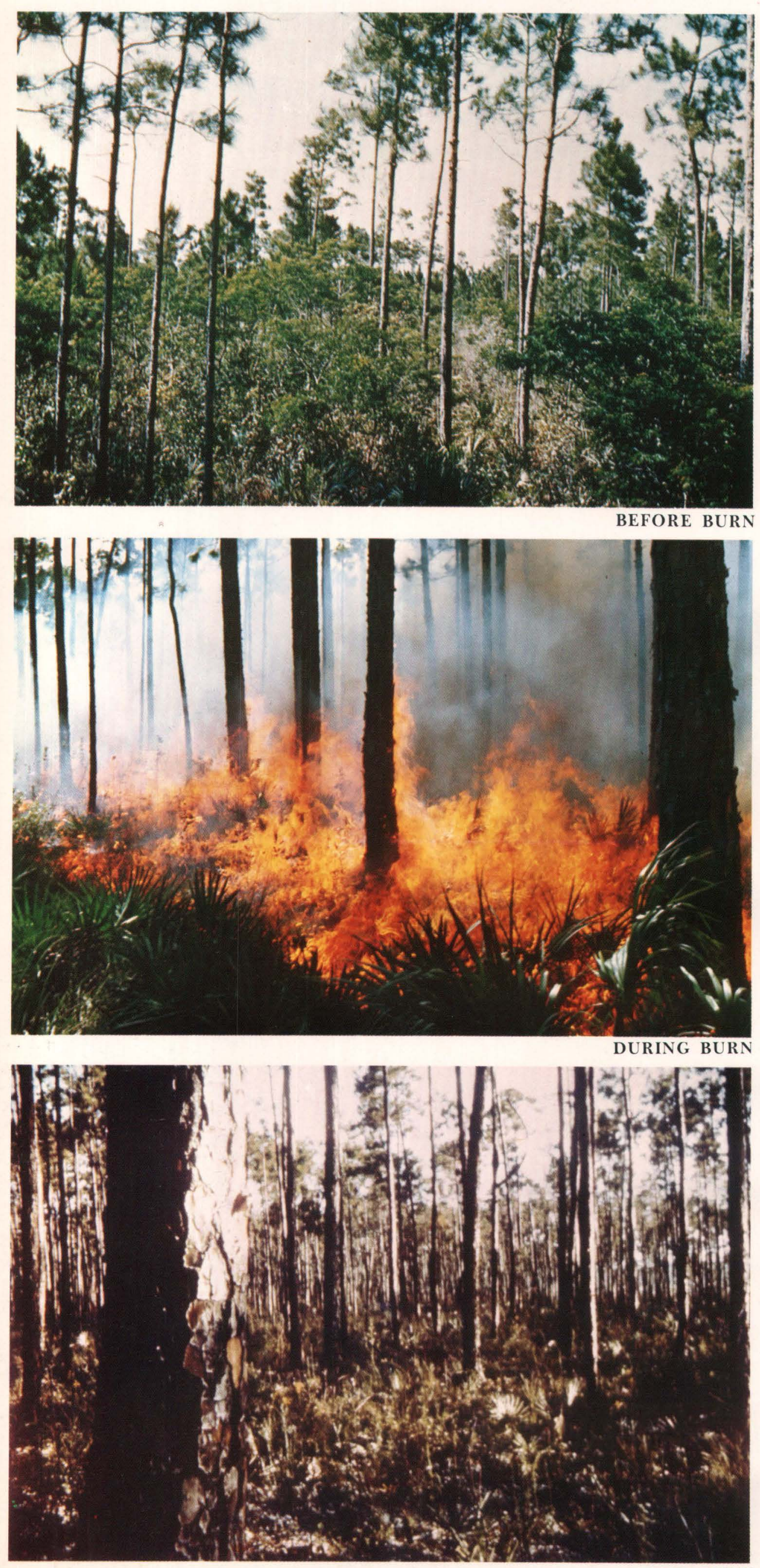

AFTER BURN

Without fires pinelands become choked by hardwoods. Following a prescribed burn, the fire resistant pines and saw palmetto remain.

\section{Wildfires and \\ Prescribed Burning}

Fire, as well as water, influences the environment of the Everglades. Wildfires are a natural occurrence. Lightning coming with the first summer rains, and following the winter and spring dry spells, touches off innumerable fires. These fires spread until they reach open water or until rain puts them out. Sometimes, if the drought has been severe, and if vegetation has accumulated for many years, wildfires may burn over large tracts of the marshes and forest.

After canals and roads disrupted and diverted the natural water supply to the park, the effect of droughts became more severe, and effects of wildfires more devastating. Since these fires occurred often during the dry season, they burned over wider areas and deeper into the peat reducing the amount of soil. Understandably much has been done to control and prevent these wildfires, but fire prevention on a large scale causes problems too. Fire fighting equipment leaves deep tire and tread tracks that mar and change the land for a long time. Unburned areas, protected against fire for too long, begin to change in character; hardwood trees crowd out the young pines, and the sawgrass grows tall and thick shading out the small species of marsh plants.

Currently, small prescribed fires are considered useful in helping to prevent major wildfires. By timing fires with the wind and water conditions, park managers burn random small patches which consumes potential fuel and at the same time creates fire breaks. These fire breaks keep natural or unplanned fires within smaller, more controllable limits. In addition, prescribed burning suppresses the growth of the hardwood understory in the pinelands

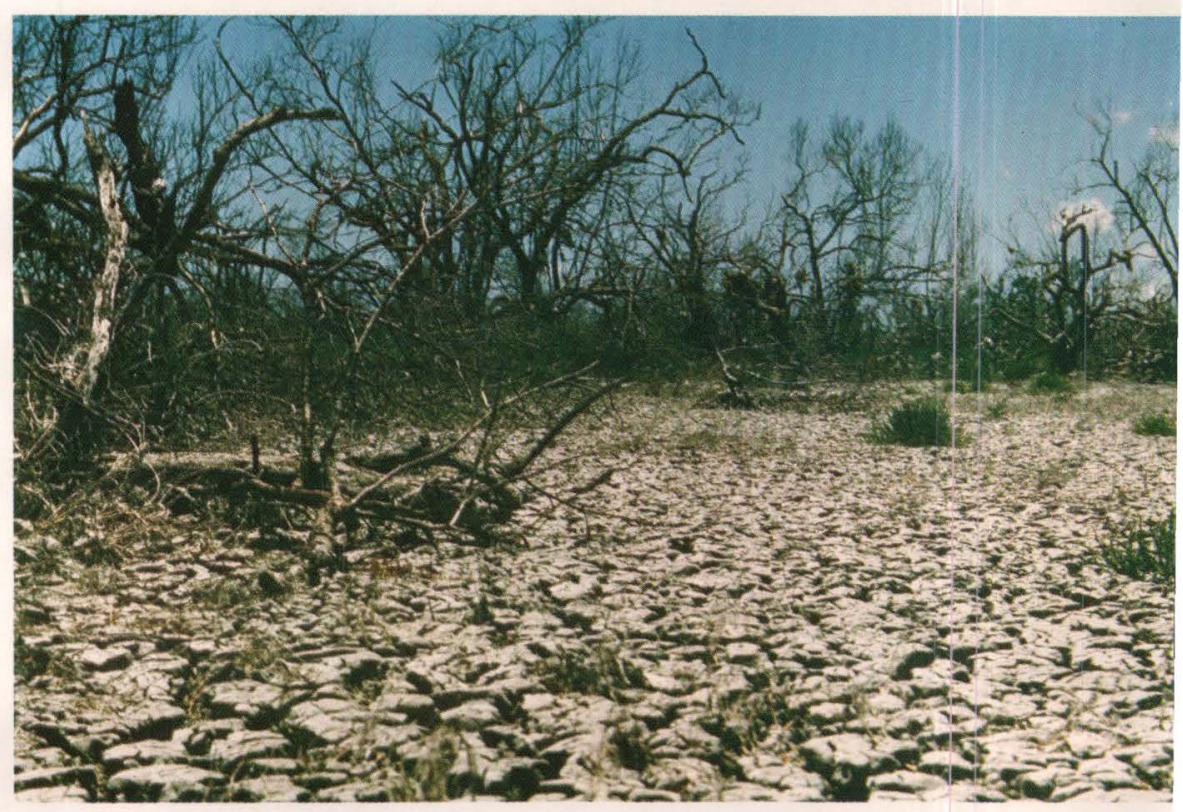

A severe water shortage caused by the normal dry season but aggrevated by diverting and impounding the natural water flow led to a prolonged and damaging drought throughout the park from 1962 to 1965 . 
and helps control the accumulation of old sawgrass. Park managers use fire both to prevent big dangerous fires and to groom the natural habitats like marshes and pinelands so that they retain their natural conditions.

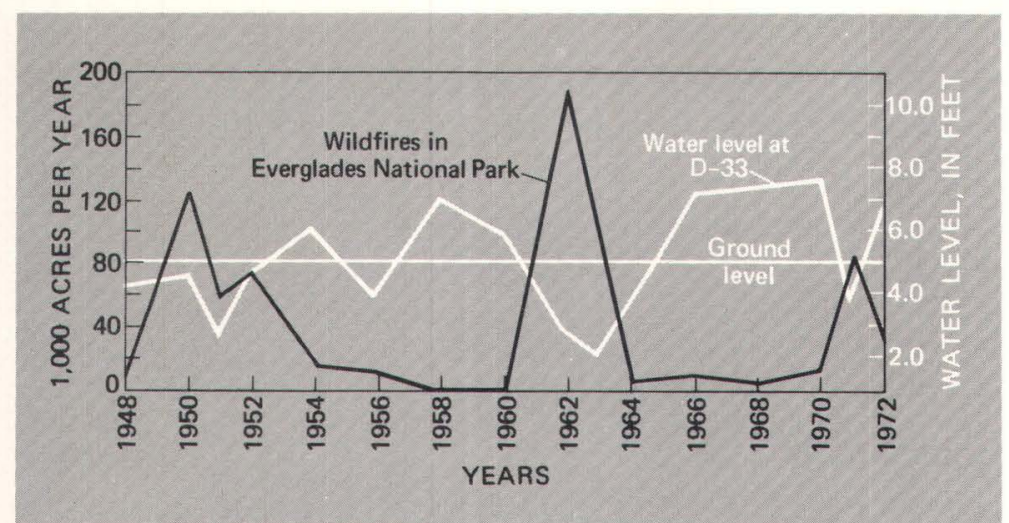

The number of acres burned by wildfires increases during periods of drought. Fires occurring during droughts are especially damaging because they burn deeply into the peat and extend over large areas.

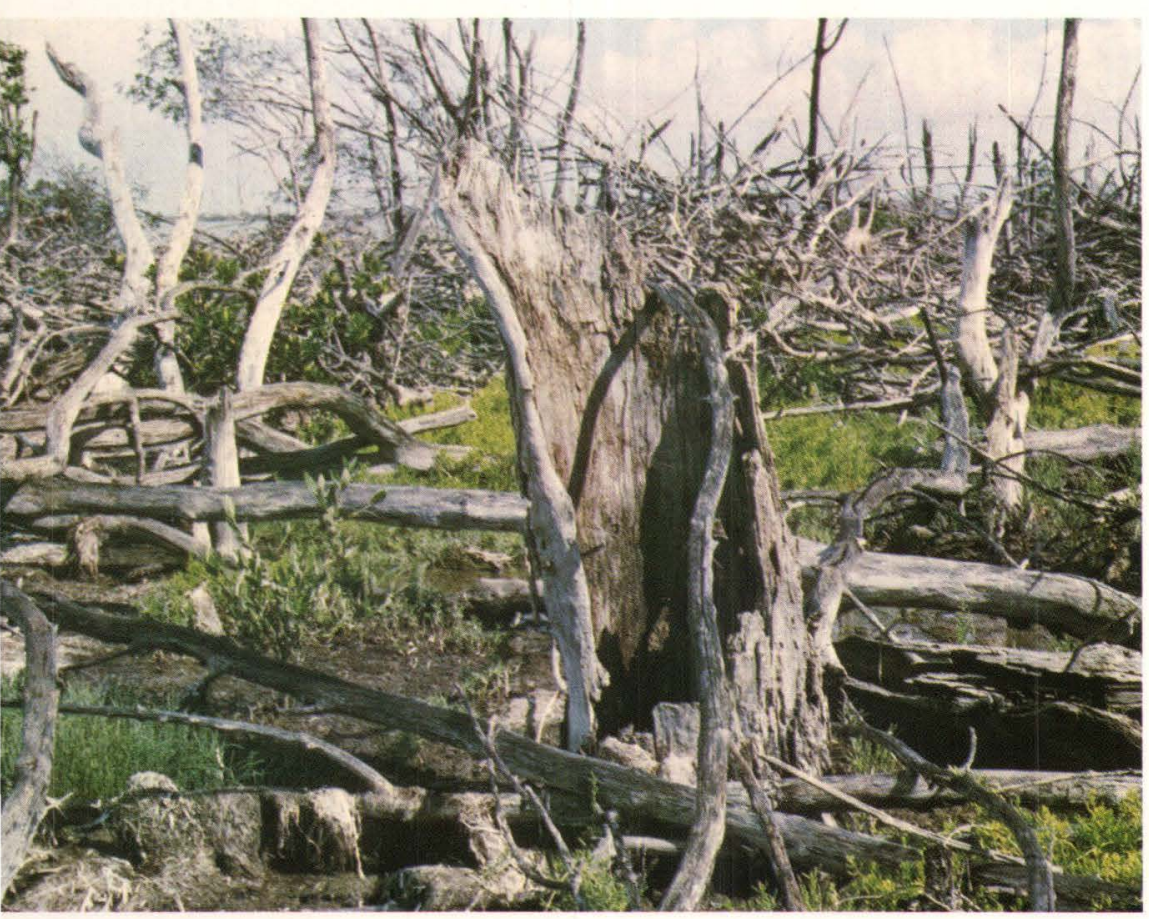

The role of the hurricane in the Everglades is both beneficial and destructive. Hurricanes provide water and sometimes bring new seeds from the tropics, but they also cause flooding, salt intrusion, and vegetation damage.

\section{Park Concerns Outside its Boundaries}

Everglades National Park includes only the southernmost portion of the original Everglades, and since it is downstream from its own natural water supply, it is dependent on what happens outside its boundaries.

Wildlife recognizes no boundaries and moves freely from the park onto adjacent wetlands. Many birds, alligators, and crocodiles feed and nest outside the park, and return to the park at other times. If these animals are disturbed, or if the nesting and feeding sites are lost to development, the park loses. Being part of the uniqueness of Everglades National Park, any attrition of these wildlife along and outside the park boundaries is cause for concern.

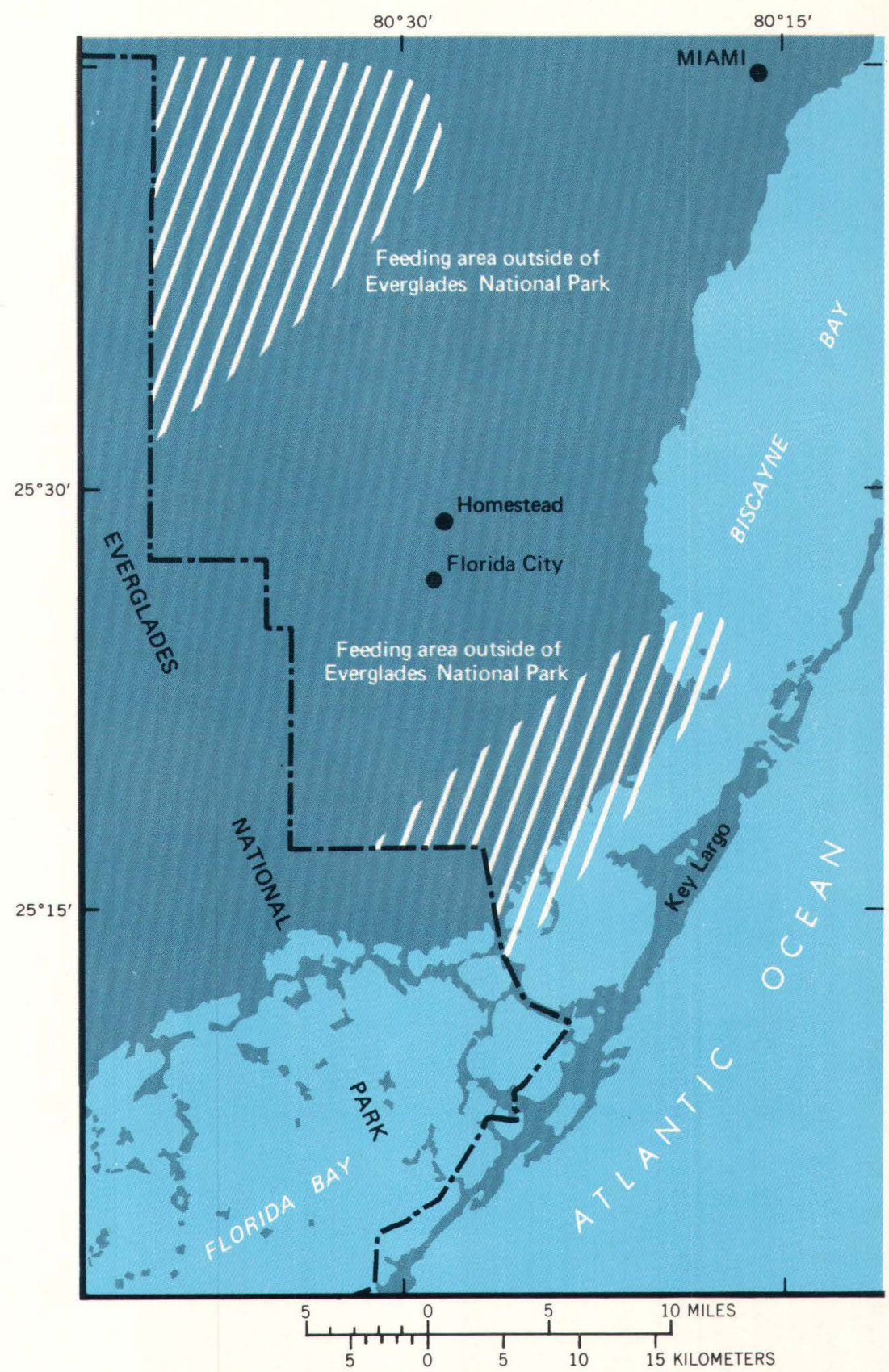

The areas surrounding the park are as important as the park itself for wildlife maintenance. Both roseate spoonbills and wood storks which nest in the park feed extensively outside its boundaries during early winter.
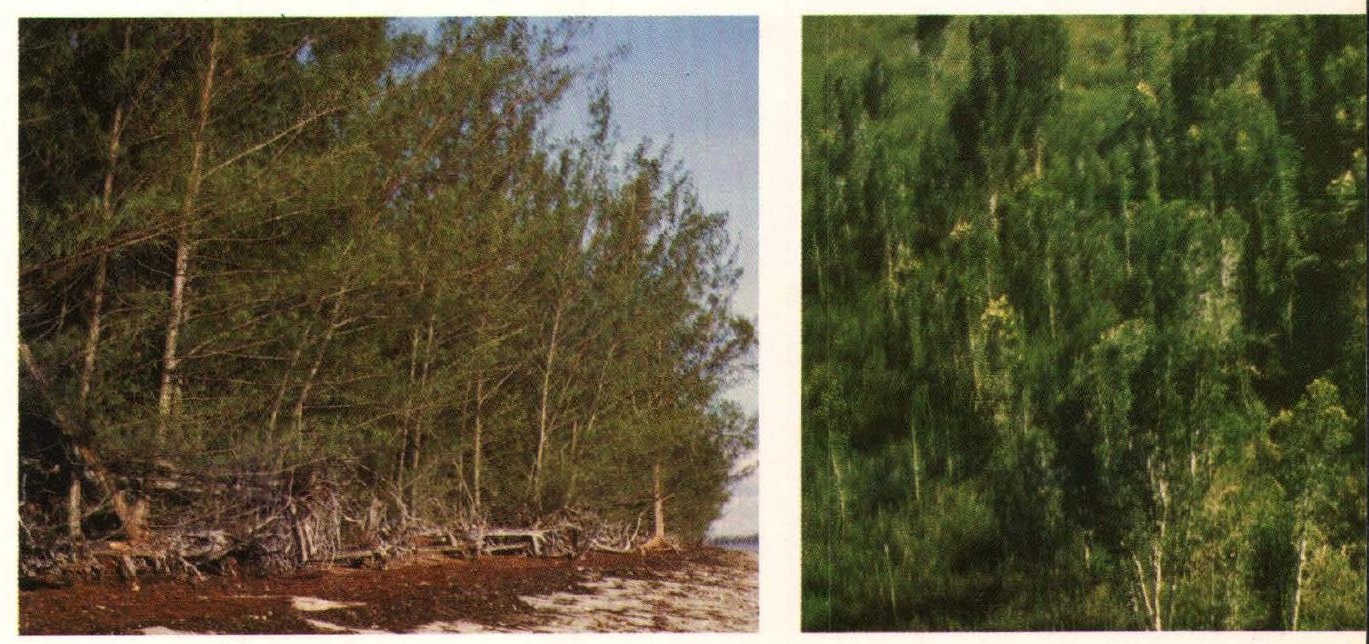

Plants such as the Australian pine, melaleuka, and Brazilian pepper (shown clockwise) have spread into the park and compete with native vegetation.

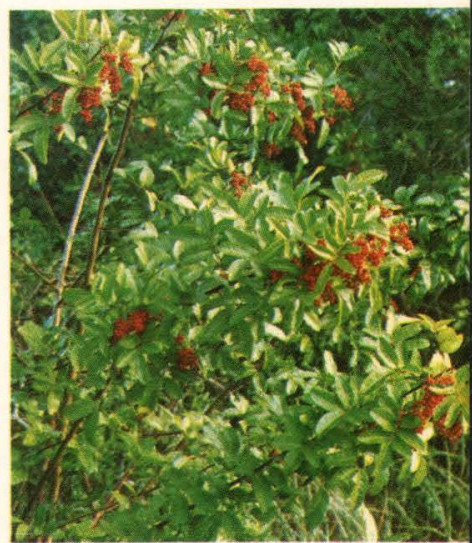




\section{COASTAL ZONE}

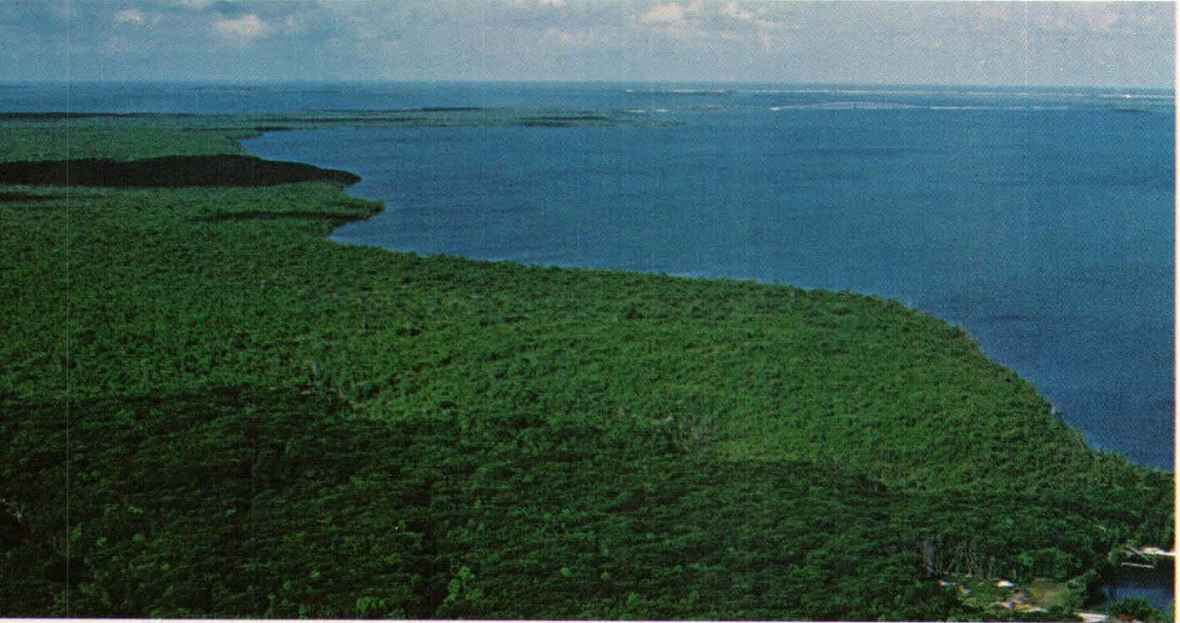

Biscayne Bay from Miami to the Keys was once mangrove coastline. Now the majority of it is developed, leaving only the southern stretch in a natural state.

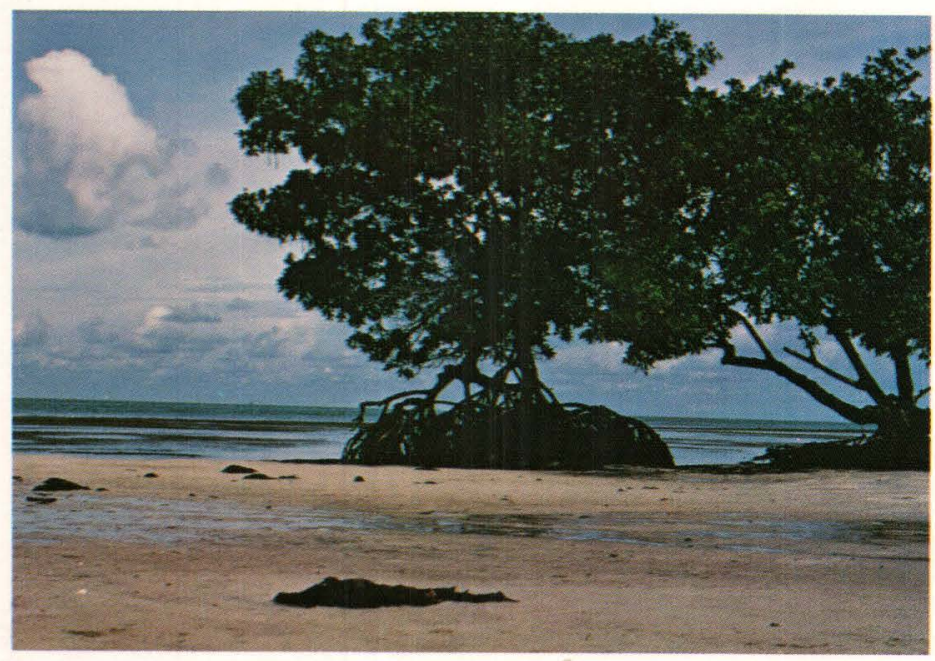

Called walking trees, red mangroves have stilt-like roots. These trees, which are tolerant of salt, live in a transition zone between fresh water and the ocean. (Photo by R. Rothwell)

North of Key Biscayne there are long white sandy beaches, but to the south the beaches disappear and are replaced by a string of mangrove-lined islands that enclose a series of shallow bays: Biscayne Bay, Card Sound, Barnes Sound, and Florida Bay. A rich diversity of marine plants, sponges, sea whips, and small corals cover the bottom of these bays. The circulation within the bays is characteristically weak and water exchange with the ocean is primarily tidal. When the bay bottom is undisturbed, the water is usually clear and supports abundant populations of shrimp, crab, lobster, and fish.

Seaward of the Keys, the Florida Current moves northward at about $3 \frac{1}{2}$ knots, bathing the southeastern edge of Florida with warm water from the Gulf of Mexico and the Caribbean. Because the water is clear and warm, coral reefs grow along the continental shelf between the keys and the continental slope. Abundant sea fans, corals, and rainbowcolored fish make this one of the Nation's most beautiful underwater regions. But the white sandy beaches, the mangroves, the crystal water, and the coral gardens are disappearing. Hotels push out onto the beaches and new homes occupy former mangrove islands. The bays are dragged, dredged, filled, and channeled, and the coral reefs plundered for their shells and tropical fish.
Biscayne Bay's clear crystal waters and coral reefs provide the skin diver with a whole new world to explore.
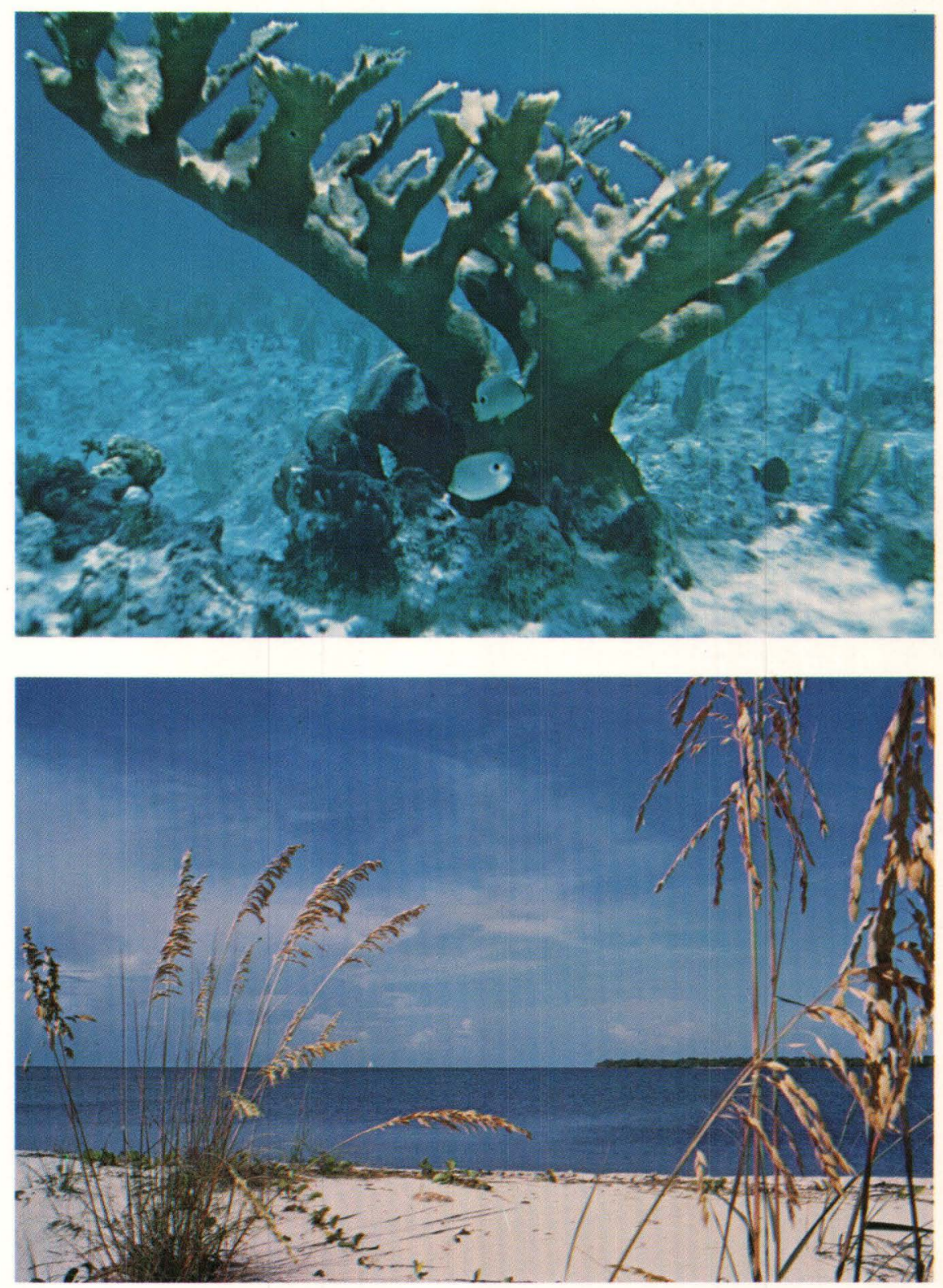

South Florida's sandy beaches are a prime attraction to tourists. Most are crowded.

\section{Dredging and Filling}

The growing population in south Dade County creates a need for more homes, apartments, and hotels. Because the water table is high, and much of the land subject to flooding during the wet season or hurricanes, building sites are limited. Most of Miami and its suburbs lies atop the Coastal Ridge, with wetlands to the west and south. To get more land for development, wetlands can either be drained or filled. To drain the marshes the water must be channeled somewhere; in Dade County this is usually to one of the shallow bays. Similarily, filling requires that the fill be dredged from shallow bays.

Removal of the dredged fill from the bay bottom eliminates the habitat of living plants and animals. There is evidence that the disturbed bay bottom requires a long time to recover. If dredging and bulkheading are uncontrolled, an entire bay, its plants and animals, and its beauty can be destroyed. Suspended sediment created by dredging is often 


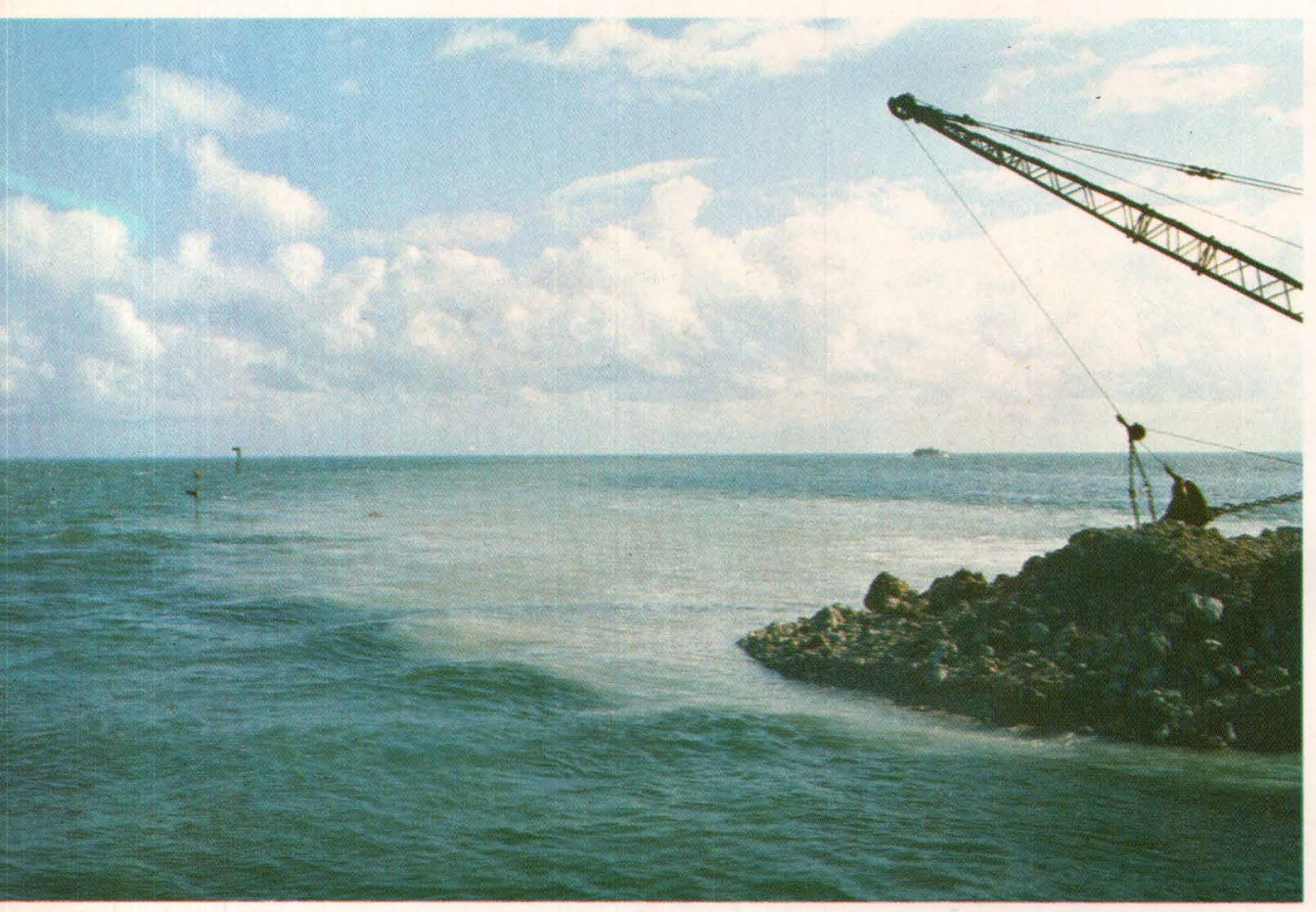

Silt from turbid or muddy waters caused by dredge and fill operations smothers and kills coral reefs.

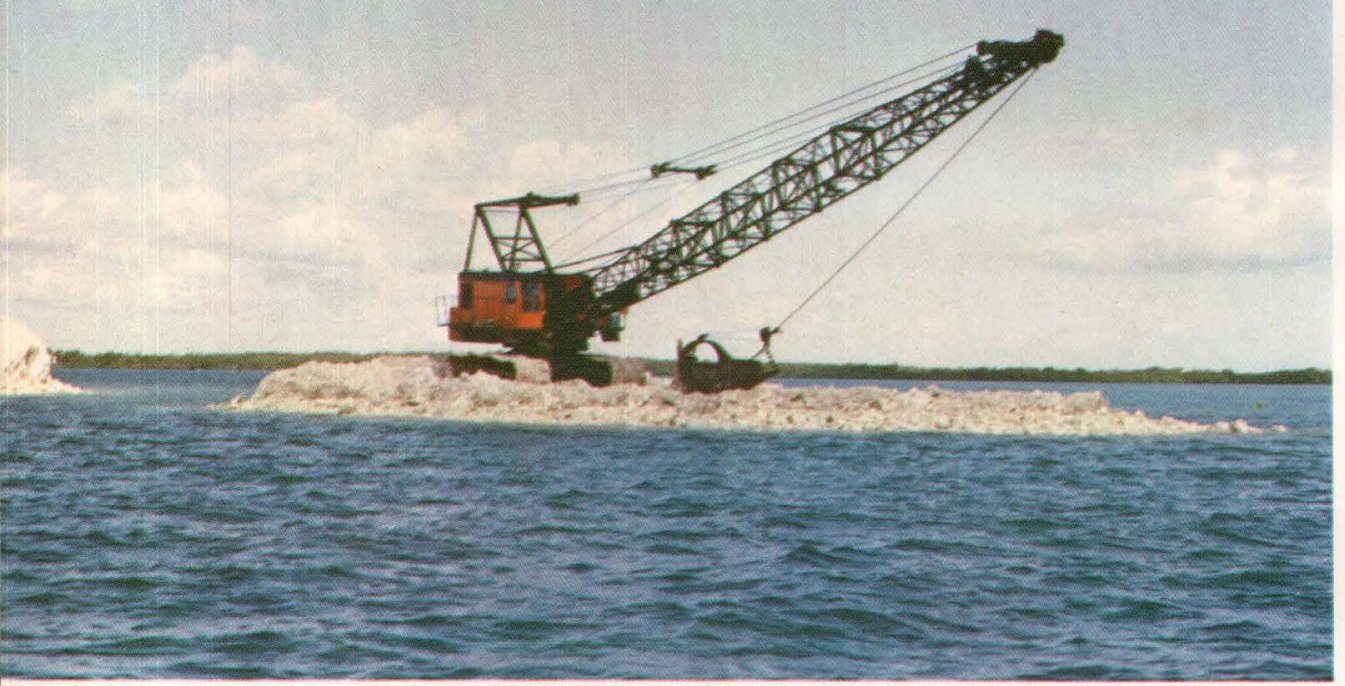

Dredging of coral.

carried by currents far from the excavation site. This sediment eventually settles out, often in amounts that coat the bottom and smother the plants and animals. Turbidity that accompanies dredging reduces light that is important for the growth of marine plants. The cost of dredging to the enviroment is high and should be considered before, not after, dredging is allowed.

Mangroves are an important part of the system that keeps the water in the bay clear and organically rich. Runoff filters through the mangroves where it mixes with salt water, and organic nutrients are added from decaying leaves, fungi, and microscopic animals that live in the rich mangrove soil. Where mangroves have been destroyed, the brackish water zone and the nutrients are reduced, with loss of health and productivity of the area. Removal of the mangrove fringe also exposes the upland urban developments to increased hurricane damage and greater tidal surges during heavy storms.

\section{Canals and Waste Disposal}

Originally only one main stream, the Miami River, flowed into Biscayne Bay from Dade County. All other fresh water reached the bay through the transverse glades during flood season, or by coastal seepage. Today, large volumes of runoff rapidly empty into the bay by canals. Fresh water no longer has a chance to mix slowly with salt water in the mangroves, but moves quickly from the farmlands, from the city streets, and from the sewers and industrial outfalls into the bays.

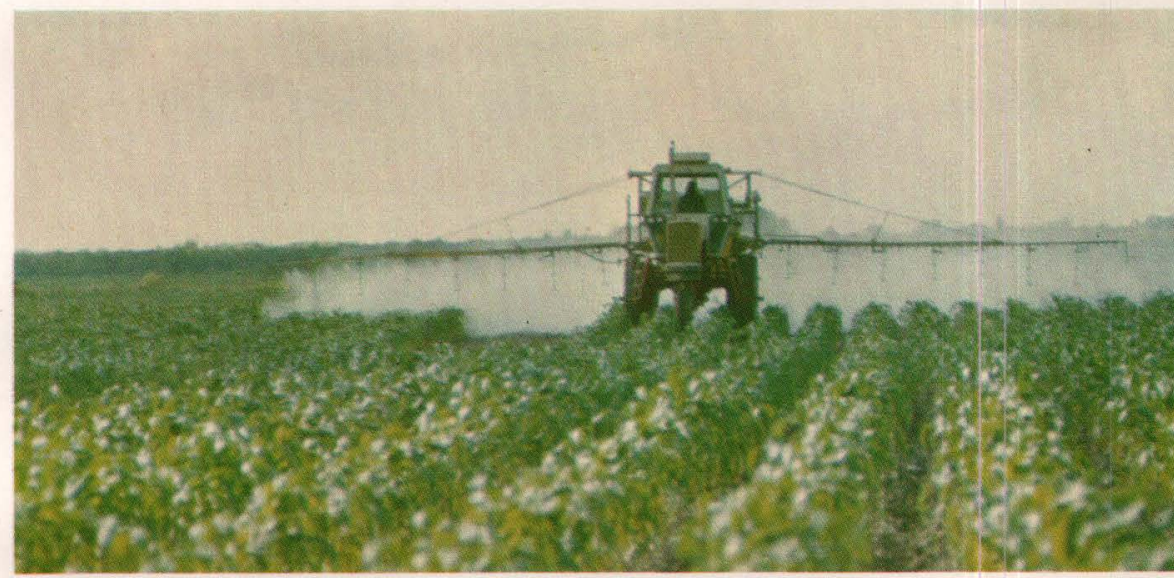

Pesticides used in the agricultural areas find their way to the coastal zones through the canals which drain the area.

Not only does the large discharge upset the natural balance of life in the bay, but the impurities and pollutants gathered along the way contaminate the water and endanger marine animals. Nutrients from the agricultural fertilizers promote algae blooms. Oil and petroleum byproducts damage intertidal plants and animals. Much of the waste water and storm-water runoff discharging into Biscayne Bay is of poor quality and tends to accumulate locally in the bay because circulation is weak. Already north Biscayne Bay is virtually nonproductive. Unless the quality of water entering the bay is controlled, the rest of Biscayne Bay will suffer a loss of productivity.

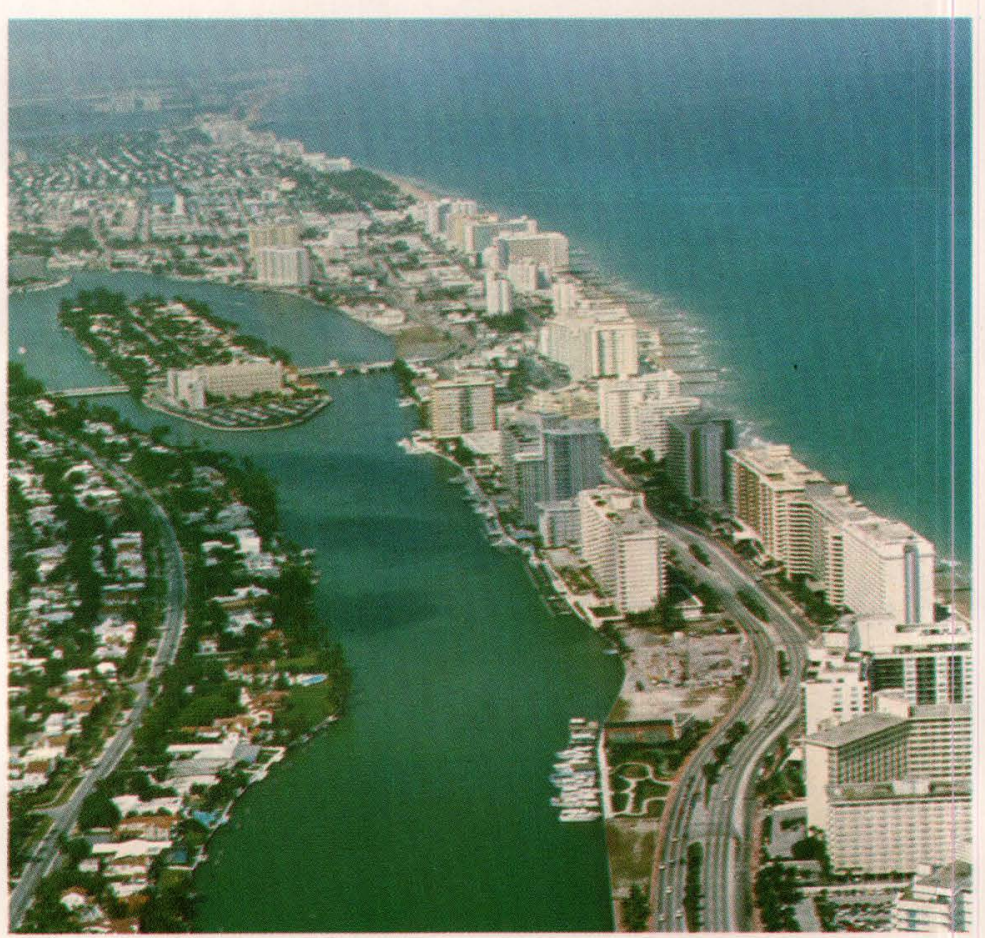

As population increases, competition for land, for housing, and for recreation becomes more acute. (Photo by Penny Zobel) 


\section{Electric Power}

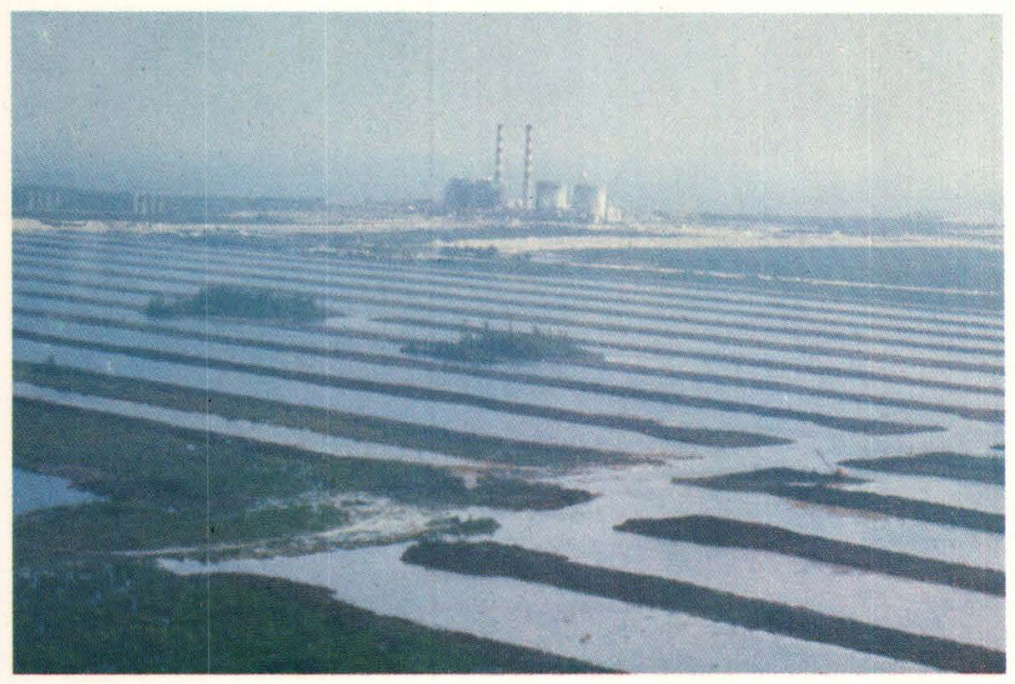

More than 10 miles of cooling canals have been constructed at the Turkey Point power plant to cool the circulating water. (Photo by Penny Zobel)

To meet projected demands for electrical energy, the Florida Power and Light Company has recently added two nuclear reactors at Turkey Point and plans to construct an additional fossil fuel plant. Until recently, water used to cool the reactors was returned to Biscayne Bay at above normal temperatures. This raised the temperatures of the local bay to a level that affected the marine environment, which was especially noticeable in summer when the water temperature in the bay was already high.

Today, an alternative method of recycling cooling water is being tried. A large system of shallow canals dug in the mangrove and coastal marsh shoreward of the bay, nearly 168 miles in total length, will conduct hot water away from the plant, allow it to cool by radiation, and then recycle. This system has led to the destruction of more than 6,000 acres of mangrove and coastal marshes.

\section{Biscayne \\ National Monument}

Biscayne National Monument, 25 miles south of Miami, contains 96,000 acres of which only about 4,500 are land, consisting of 25 small islands. These islands form a north-south chain which separates the southern part of Biscayne Bay from the Atlantic Ocean. On the north, the monument is partly separated from the turbid and polluted waters of north Biscayne Bay by a shallow bank. South of the monument, the bay is shallow and because it is enclosed, water circulation is poor. Floating wastes and pollutants collect easily, and the temperature of the water fluctuates rapidly.

The marine environment within the monument is extremely diverse and fragile. Many fishes spend their juvenile life in the shallow, grassy areas of the bay. These areas depend on tidal flushing of the mangrove forests for nutrients. The grasses also act as sediment traps and maintain water clarity essential for coral life and growth.

Offshore from the islands, the reef slopes gently downward, past the scattered and myriad patch reefs to a submerged grassy plain of about $30 \mathrm{ft}$. depth. It then rises abruptly

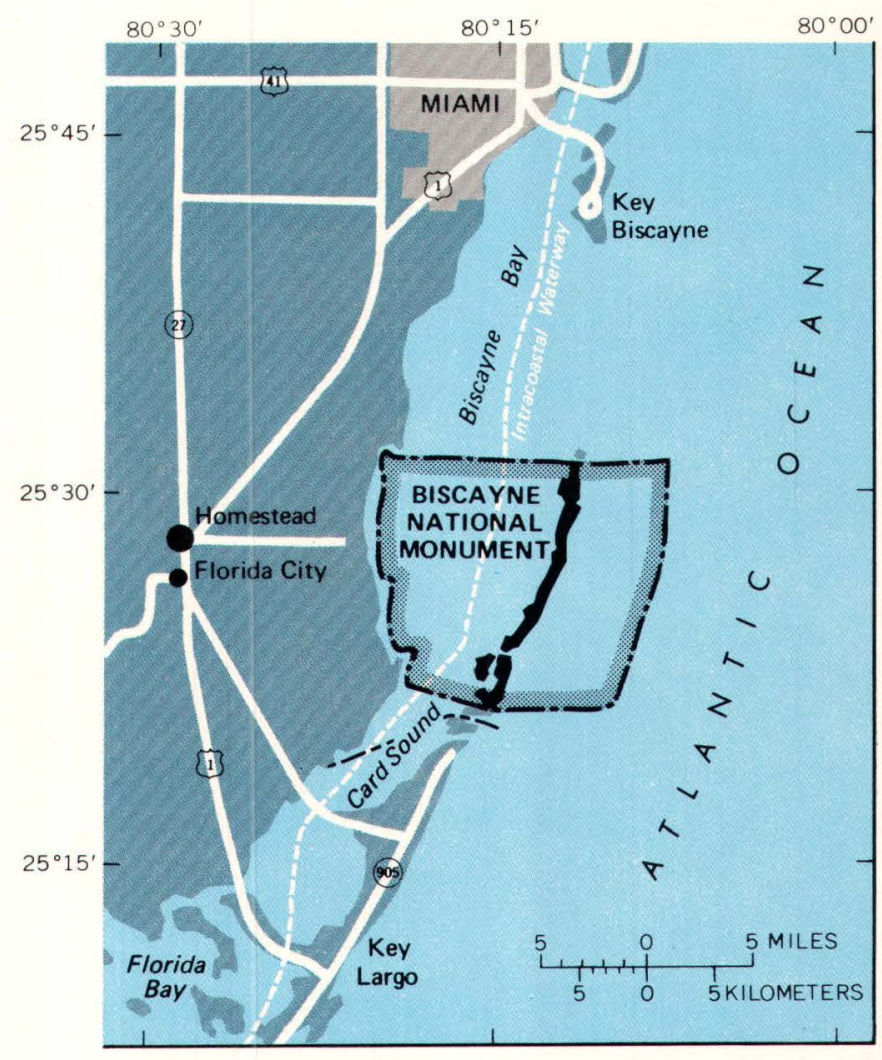

Biscayne National Monument includes the upper part of the Florida Keys as well as large parts of south Biscayne Bay and Card Sound.

onto the several shallow rubble reefs. Passing the ancient dead coral reefs, the bottom then slopes again downward and into the strong, warm Florida Current, which contributes to the tropical vegetation growing upon the islands and to coral growth.

Urban development is impinging upon the environment of the monument, which may go the way of the central and northern sections of Biscayne Bay that only a generation ago displayed a similar natural beauty. Large suburbs are being planned along much of the western shore of south Biscayne Bay. Canals and waterways are planned through the mangroves, and many of the existing mangrove forests would have to be filled and leveled to accomodate these planned cities. Dredging and channeling the bay bottom within Biscayne National Monument itself has been proposed. Without proper controls this encroachment can destroy the corals, grasses, reefs and fishes.

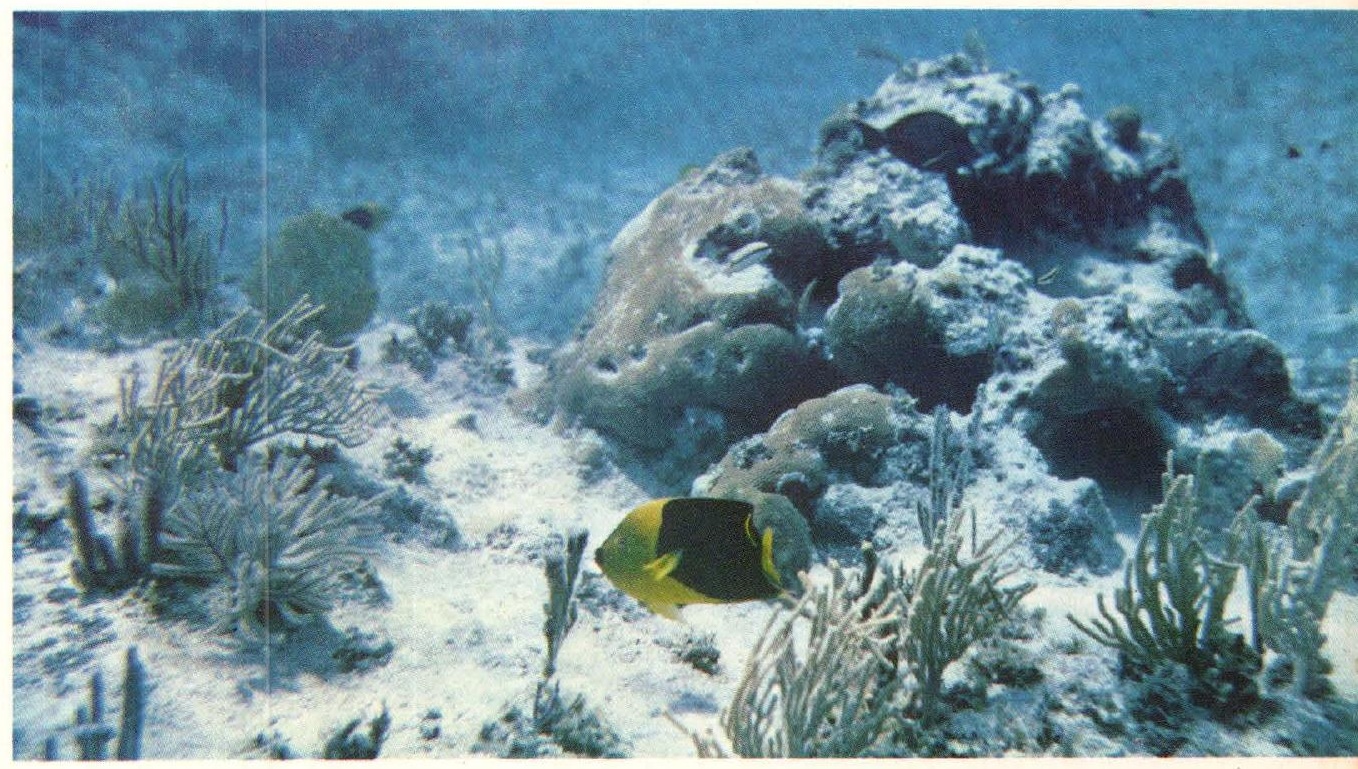




\section{COASTAL ZONE}

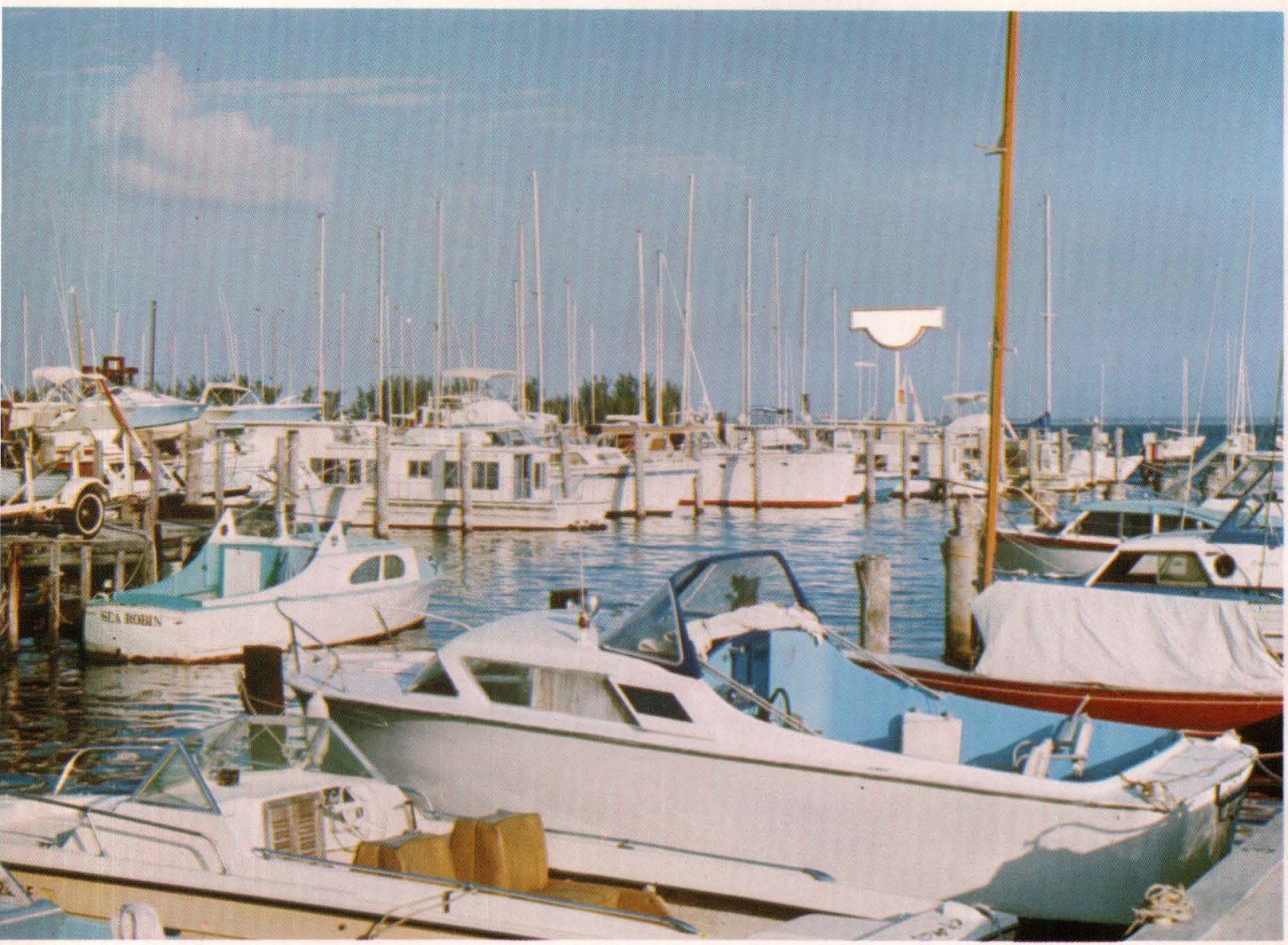

Boating is popular, and marinas are prevalent in the area.

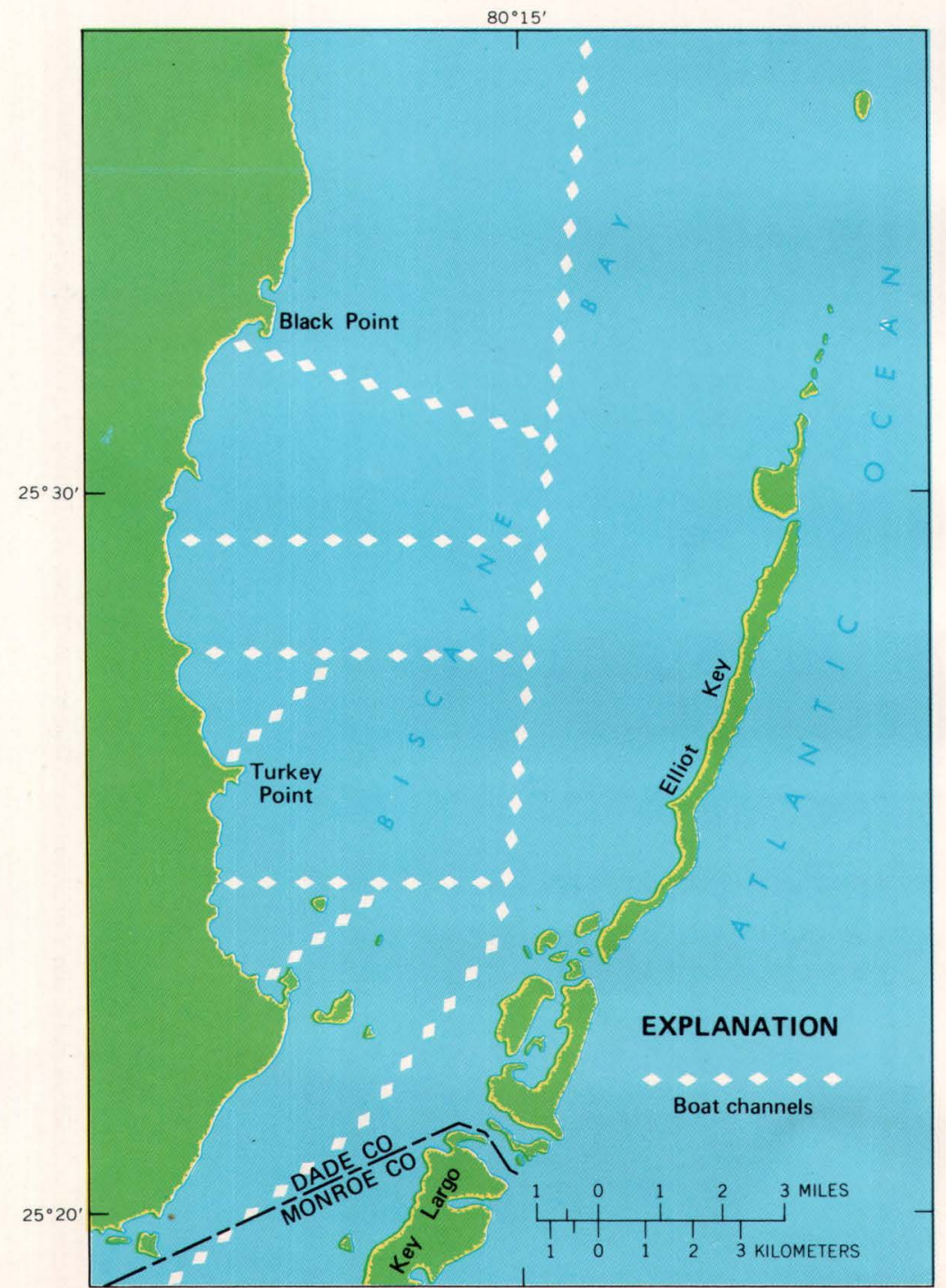

Because Biscayne Bay is shallow, boat channels must be maintained.

\section{Boating and Visitors}

As more people visit Biscayne National Monument each year, the problems of environmental protection become more acute. Since much of south Biscayne Bay within the monument is shallow, often less than 3 feet, the bottom becomes scarred where boats run aground or where the props cut furrows through the grass beds. These scars heal very slowly, if at all. Unless boat operators observe marked channels and avoid certain very shallow parts of the bay, further damage to the bay bottom will ensue.

Boats also present sanitation problems. Currently there are no sanitation requirements for small boats operating in south Florida; the ever-increasing disposal of wastes directly to the water poses a serious pollution threat.

Projected demands for boating in South Florida will require more boating facilities, more marinas, and more channels. Marinas must be carved out of the existing mangrove shoreline. In order to link these marinas with deep water, channels must be dredged into the bay. Dredging, however, creates suspended sediment and turbid water and gouges out swaths of living plants and animals. These swaths are deeper and more permanent than boat scars.

South Biscayne Bay and the reefs offshore from the Keys have always been good fishing grounds. In order that this area remain productive, the bay has to remain healthy and stable. The number of fishermen and skindivers are also increasing, so some controls may be necessary to sustain this fishery resource.

At present, means to control visitor uses deleterious to the Monument are being studied. For example, bottom scarring by boat propellers will be reduced by improved channel marking. Consumptive uses of the monument will be discouraged and nonreplenishable resources protected. Proper 
controls can be implemented by the National Park Service only within the legal jurisdiction of the monument. But the natural boundaries of the ecosytem extend well beyond this artificial boundary and the effects of man's activities are far reaching. To insure protection of the monument, government agencies and the concerned public should cooperate in identifying and attempting to control the multitude of potential threats posed by man, his developments, and his technology in all of the surrounding area.

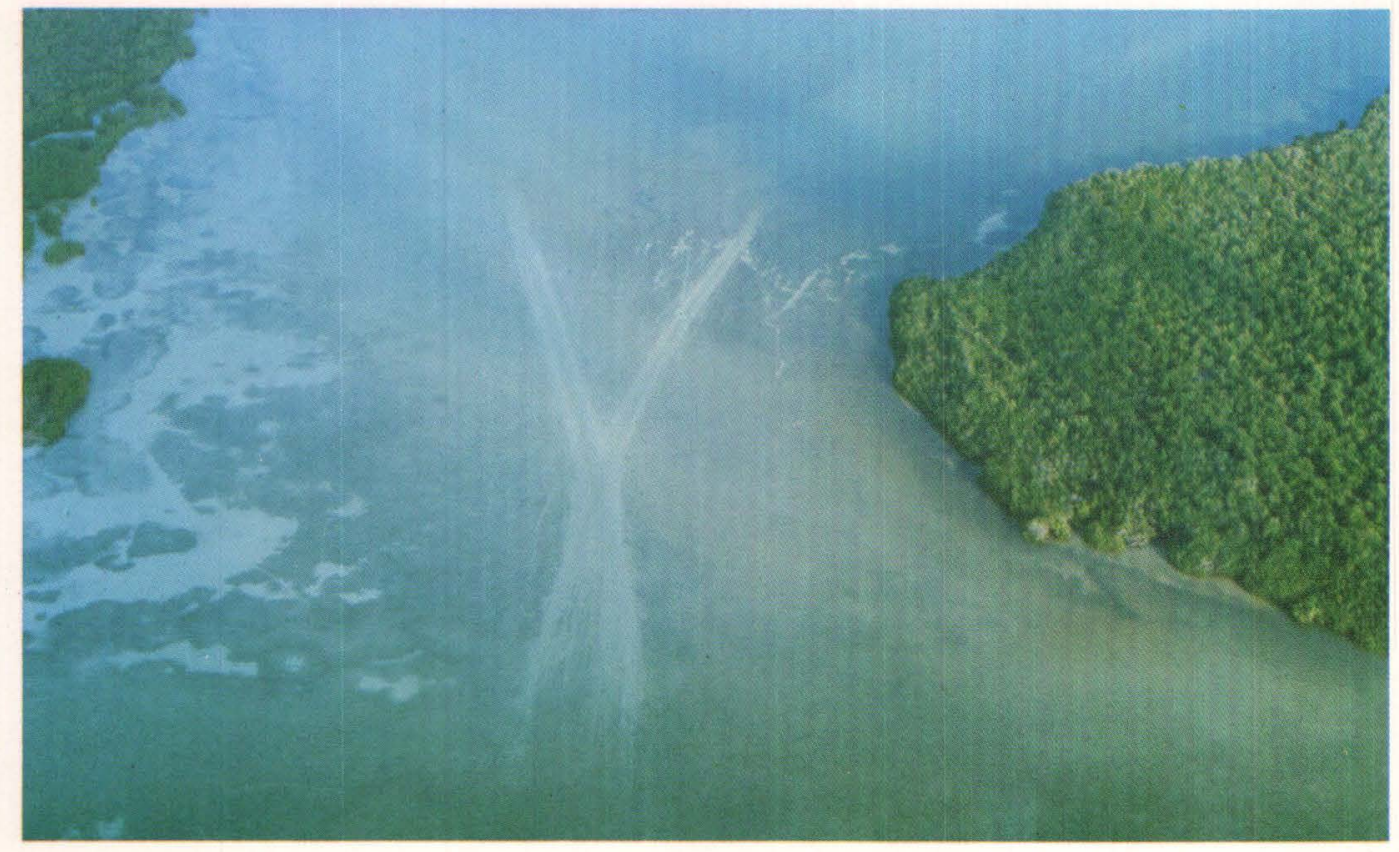

The shallowness of Biscayne Bay makes it a prime target for boat ruts. The propellers of boats not using channels kill the vegetation, which takes years to regrow.
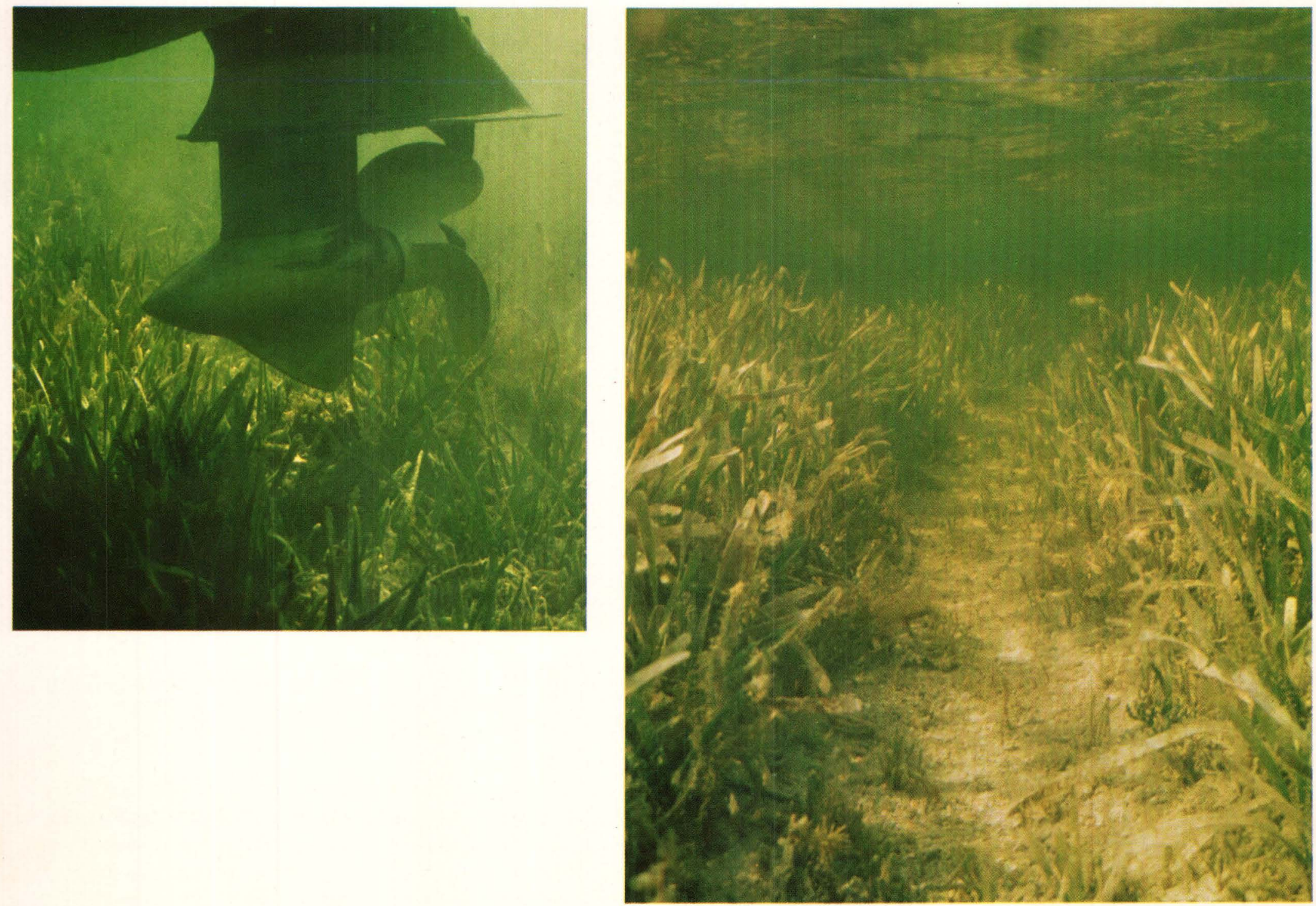


\section{FISH AND WILDLIFE}

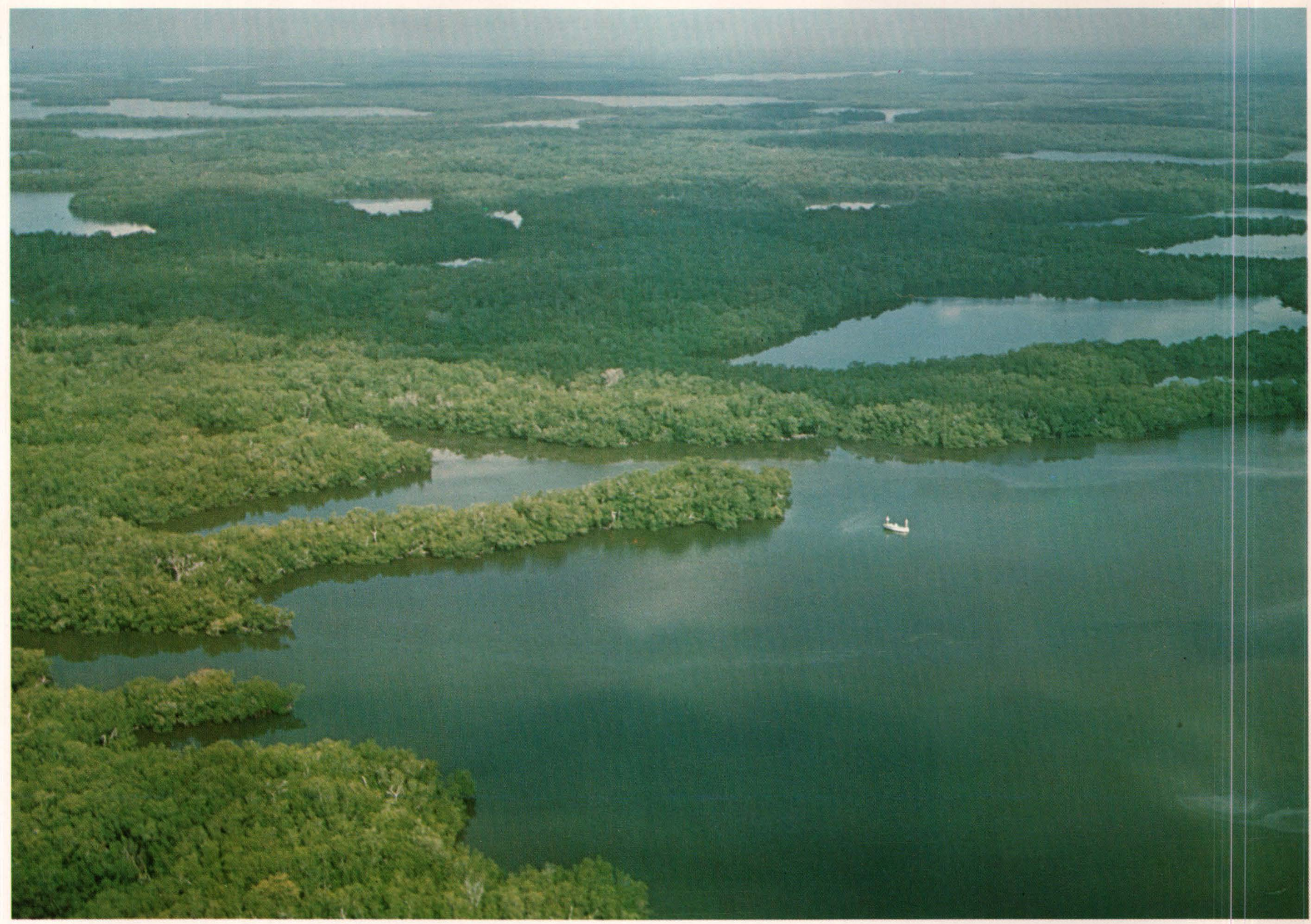

\section{The Estuaries}

Estuaries are tidal reaches where sea and stream mingle. The fresh water that meets the sea in the estuarine zone of Dade County came from the Everglades and the coastal marshes. Within this estuary are the wide seagrass flats and dense mangrove forests of the tidal zone. Large areas are constantly covered by shallow water, and salt content is less than that of the sea because of the seasonal inflow of fresh water.

This estuarine complex is very fertile. Fresh water with suspended material from the land-dissolved nutrients, humus, top soil-is mixed by the tides with mineral-rich sea water and organic products of underwater decay that currents prevent from settling on the bottom. This fertility is enhanced by the warmth of a subtropical climate. The Dade County estuary complex is more productive than the best Midwestern farmland.

The estuaries furnish a sheltered environment for small and microscopic plant and animal life which forms the abundant food for successively higher links in the food chain. The rich nutrients developed in the estuary are moved

\section{PREDEVELOPMENT}

through the mats of underwater sea plants on the bay side and around the shallow mangrove flats on the land side by tidal currents.

Much of the life of our coastal seas begins in and depends on such estuaries. They are, for the sea, the cradle of life.

The value of the Dade County estuaries as spawning grounds, nurseries, or growing-up places for myriads of important commercial species such as shell fish, crustaceans, and finfishes cannot be over emphasized. Rarely are nature and the modern urban conglomerate in such close juxtaposition as in the estuaries of Dade County. The amenities which arise from this estuarine zone attract millions of people to the area. But this zone is most severly impacted.

The limited resources of the Dade County estuaries, as a foundation for economic growth, are endangered by dredging and pollution. The transition from use to overuse is subtle. At first, a few fish die. An oil spill kills a 


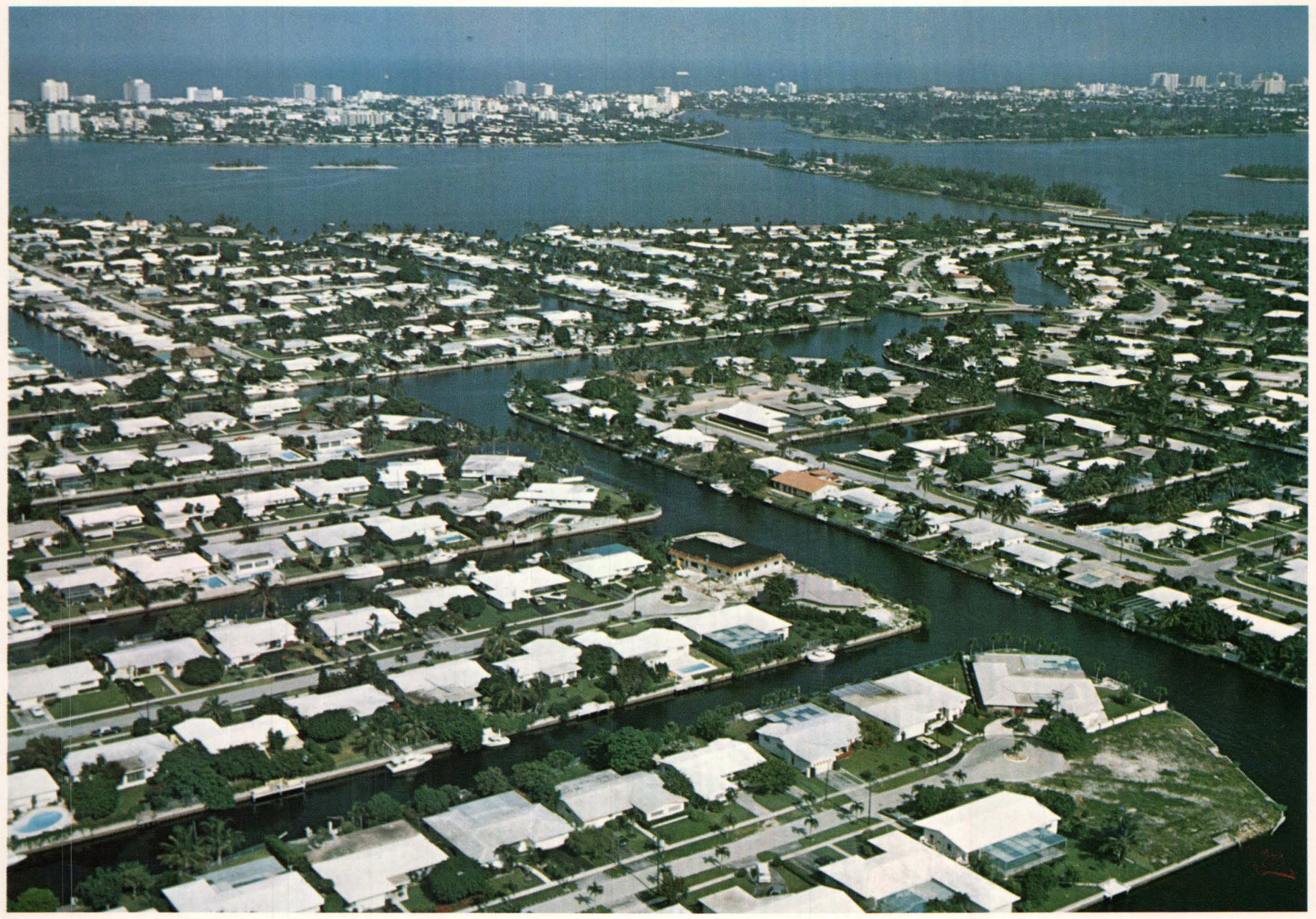

\section{POSTDEVELOPMENT}

thousand birds. Completely unnoticed are the millions or billions of plankton which die as a result of some toxic discharge into the bay. The loss of plankton in a localized area changes the species composition of fish, which in turn, changes the species composition of birds and other higher forms dependent upon them. Then, people are directly affected: a beach area is closed for a few days or months. These subtle effects result in gradual environmental degradation which can eventually spoil the area.

Urban development is not subtle. It can destroy much of the estuaries' attractiveness and eliminate the habitat of thousands of wild things. Some, like the manatee, the southern bald eagle, and the great white heron, are already being pushed back by such encroachment.

If habitat losses along the Dade County coast continue at the same rate as in the recent past, the estuarine values which contribute much to the economy and attractiveness of south Florida will be lost. The thin line of higher land consisting of the beach, dunes, and near shore areas of the coast is the most desirable for development. This type of land has been almost entirely converted to urban uses. Of the original 12,600 acres, 92 percent has been lost to urban development. Only 1,000 acres remain undeveloped. As the higher land is used up, mangrove areas become increasingly desirable, and are bulkheaded, filled with dredge, and made into real estate. Of the 99,700 acres of estuary, mostly mangrove forest, in Dade County, 15,400 acres, or about 15 percent, has already been lost as productive estuarine habitat.

Florida law (the Randall Act) requires that development in an estuarine area receive careful biological assessment by the Department of Natural Resources. Recommendations are made to the Trustees of the Internal Improvement Trust Fund who may deny or grant a permit to develop within the estuarine zone. The Fish and Wildlife Coordination Act also requires that the Bureau of Sport Fisheries and Wildlife evaluate the development and make recommendations before any federally required permits are granted. 


\section{FISH AND WILDLIFE}

\section{Endangered Species}

In south Florida, the transition from primitive to highly developed conditions in less than a century has resulted in the constriction and even loss of habitat for many species. For its size the area has a long list of rare and endangered animals. Among the species in this area to be threatened

EVERGLADE KITE

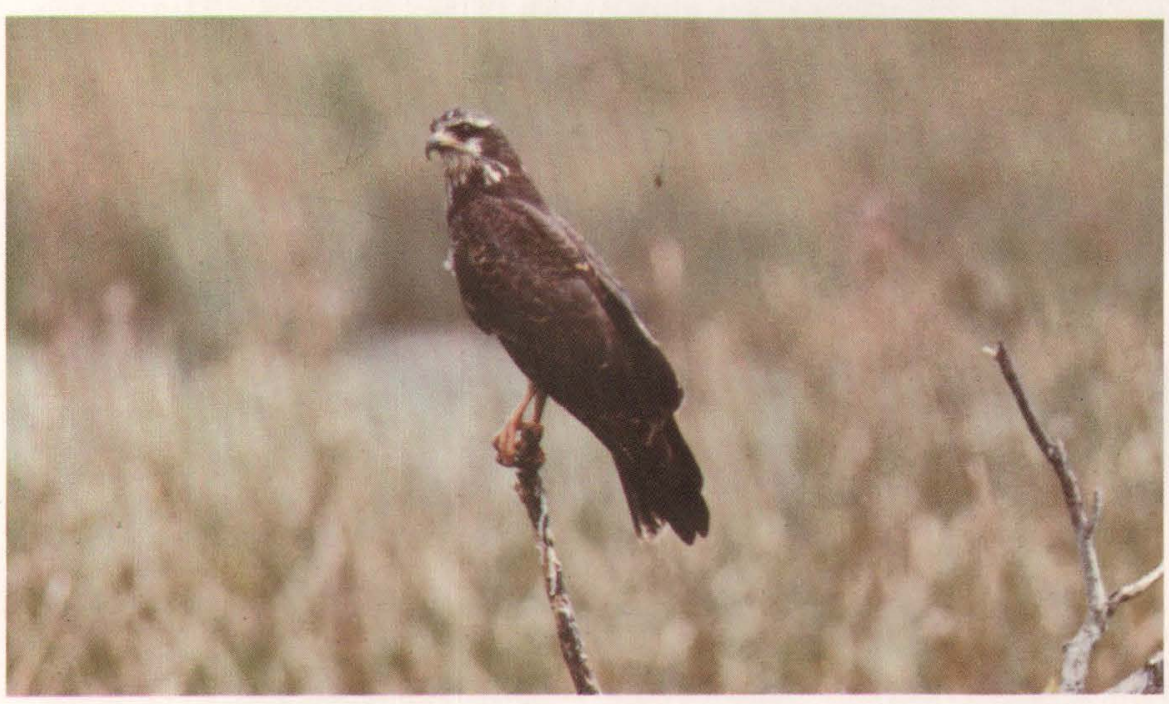

extinction. The survival of the Everglade kite is dependent entirely upon the aquatic habitat necessary for the production of the apple snail, the kite's sole source of food. The survival of the manatee and the great white heron are dependent upon the quality of the water and the presence of the mangrove flats in the estuarine zones of the county. The southern bald eagle will not nest in close proximity to man. In order to retain this species in the Dade County area, it is necessary that buffer zones be provided between the nest sites and land development.

The Florida Game and Fresh Water Fish Commission is authorized by State law to protect 23 designated species threatened with extinction. The Rare and Endangered Species Conservation Act of 1969 authorizes the Bureau of Sport Fisheries and Wildlife to support the State in its efforts to preserve these and other designated species.

Consideration should be given to acquisition of areas as refuges for threatened species, especially in the mangroves for the manatee and other species that require this unique aquatic environment.

The Everglade kite and the Florida panther are two of the endangered species in south Florida.

FLORIDA PANTHER

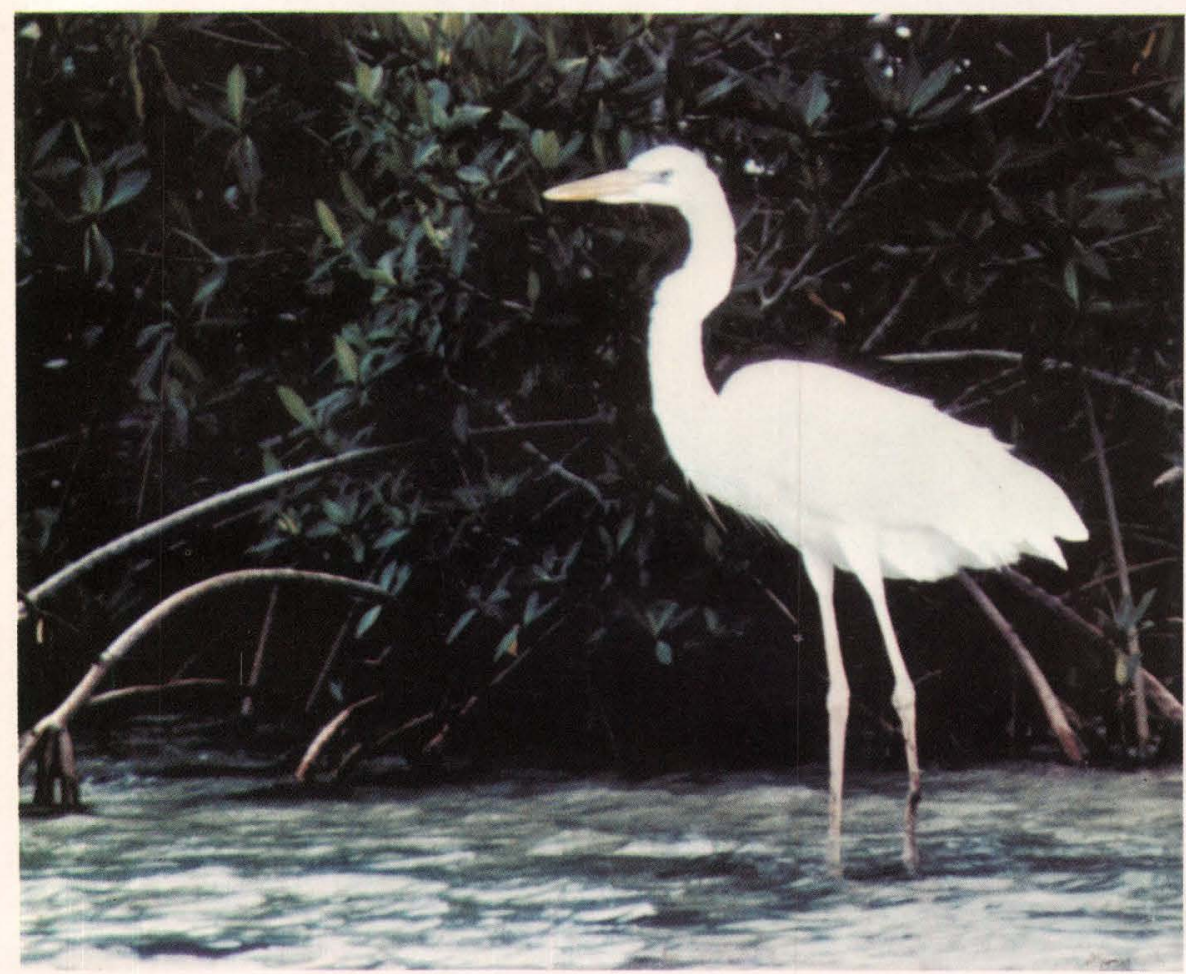

GREAT WHITE HERON

with extinction are the Everglade kite, the Florida panther, the manatee, the great white heron, the Key deer, the southern bald eagle, the brown pelican, the alligator, the crocodile, and the mangrove fox squirrel. Without exception, the reduction in the numbers of these animals in Dade County has been the result of loss of habitat. Severe changes in habitat have occurred because of unregulated drainage, dredging, and fillings; and poorly conceived channelization projects; and uncontrolled changes in vegetation by urban and agricultural development.

The recent reversal in numbers of the Key deer and the American alligator demonstrates that the preservation of suitable habitat aided by supporting laws and human protection, enables endangered species to rebound from near
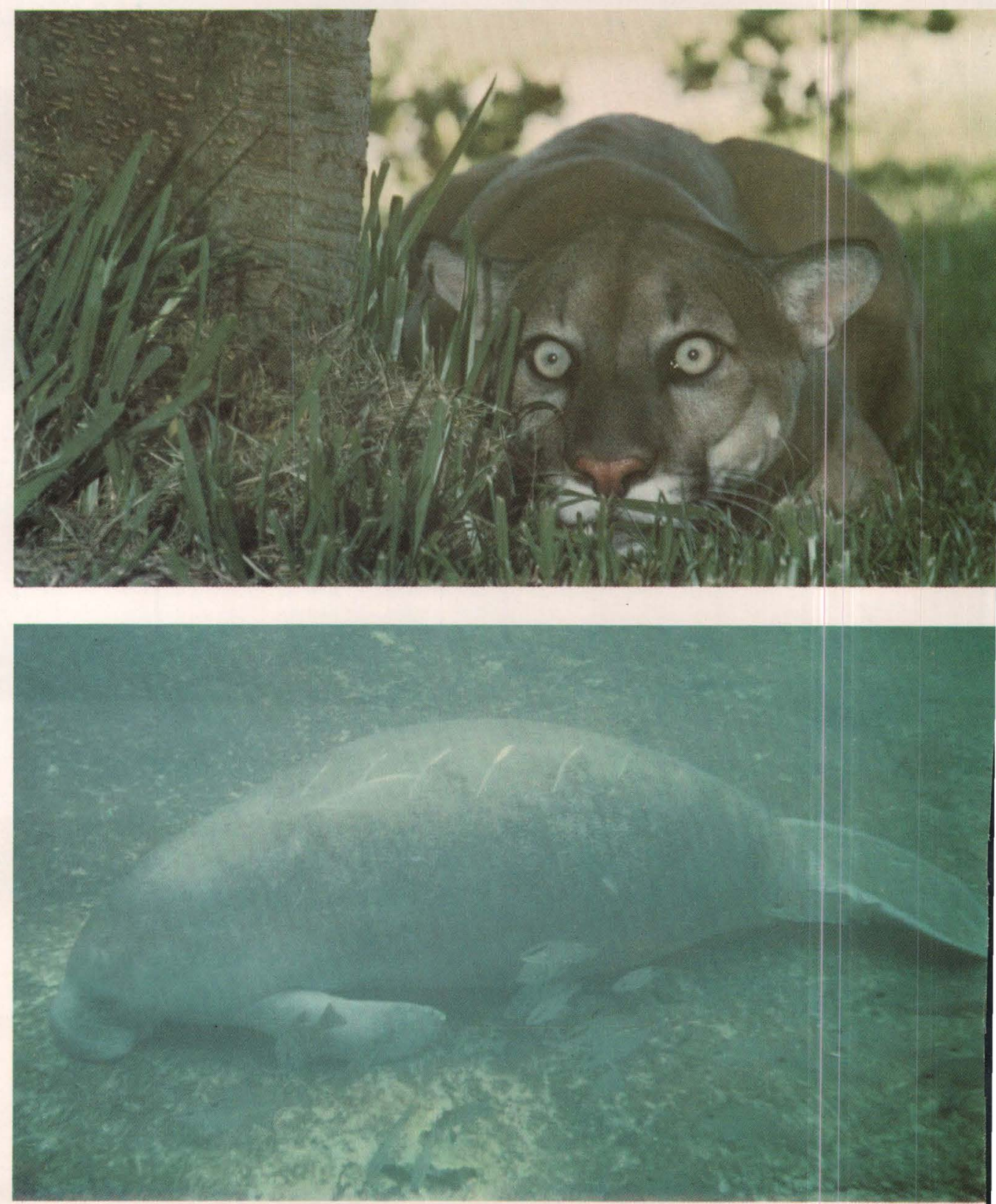

Marks on the back of the manatee were made by the blades of an outboard motor propeller. 
Wildlife is more sensitive to environmental changes than man. Understanding the requirements of wildlife species and knowing their reactions to certain environmental changes provide us with an invaluable environmental barometer.

\section{Fish and Wildlife Oriented Outdoor Recreation}

The importance of fish and wildlife oriented recreation in Dade County is borne out by the fact that this county has the largest fleet of private, party, and charter fishing boats in the State. In 1970 more than 14,197,000 salt water fishing trips were made in the county. Included are all types of salt water fishing: from bridge and pier, surf and wading, and boat fishing. In addition, 5,646,400 fresh water fishing trips were made during the same year. As would be expected, fewer hunting trips were made; however, this activity is nonetheless important. Almost one million (961,476) hunting trips were made in Dade County during 1970.

The most important impact of these activities on the resource is the result of peak-day participation. For salt water fishing the peak-day participation in 1970 was 197,804 trips; for fresh water fishing, 74,179; and for hunting, 27,998. Systematic comparison of these activities with the available

MANGROVE AND ESTUARINE ZONE
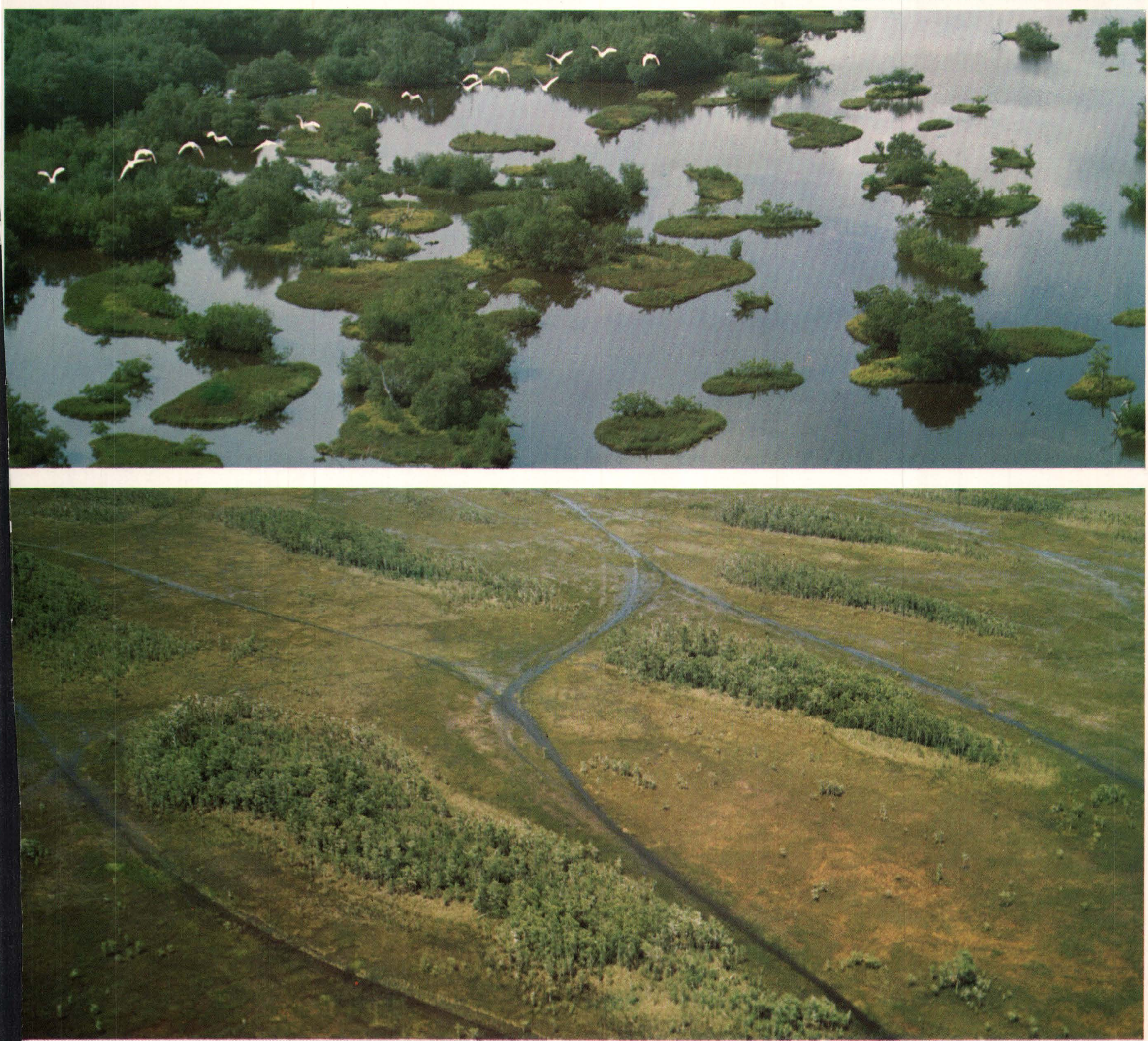


\section{FISH AND WILDLIFE}

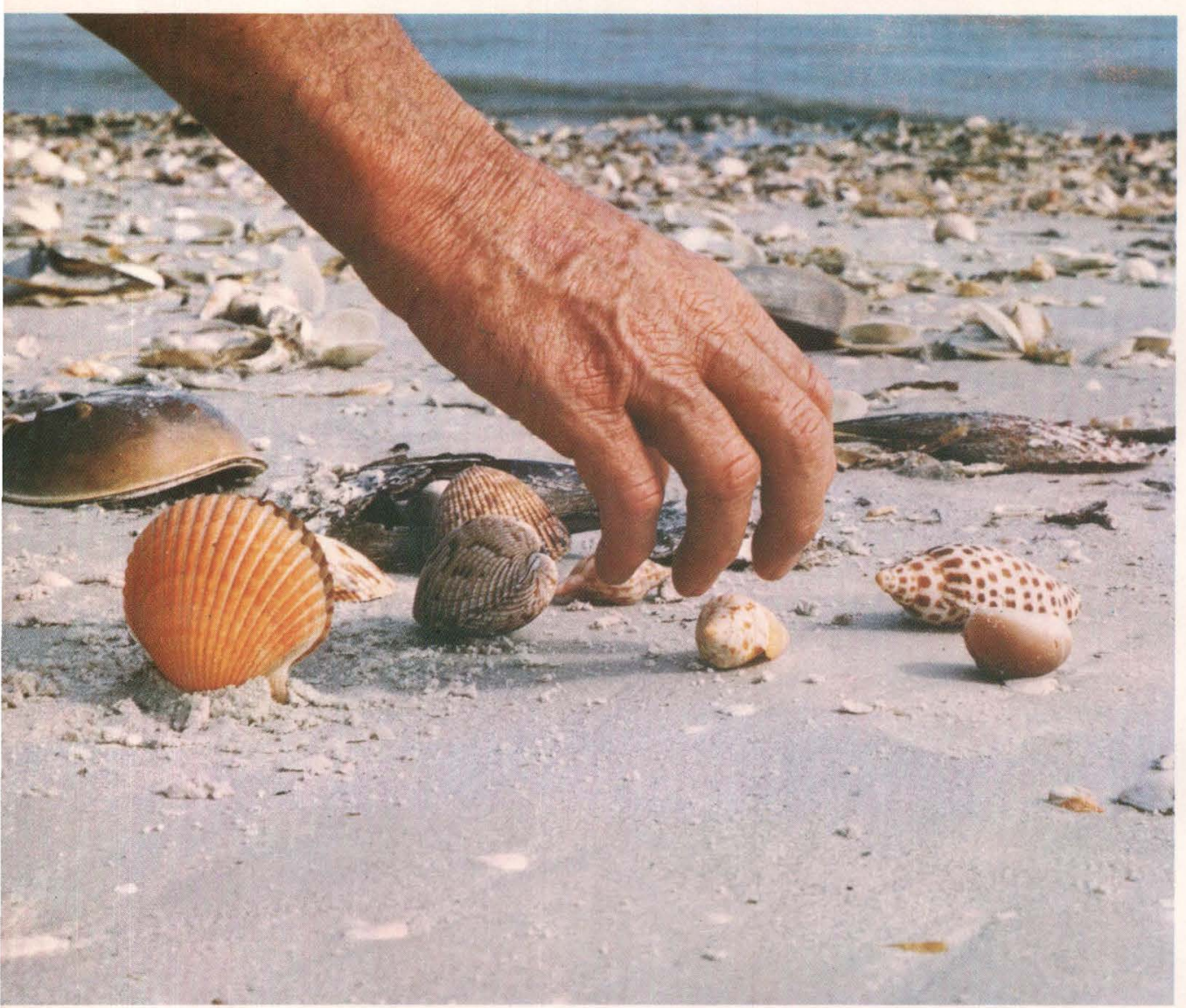

habitat services and human populations indicates that optimum peak-day trips for the same period would have numbered only 38,606 for fresh water fishing; 92,717 for salt water fishing; and 14,280 for hunting. In each case the peakday participation almost doubled the optimum. Such highuse days place undue strain on the habitat and emphasize the importance of maintaining no less than the present quantity and quality habitat necessary to support these activities.

Wildlife observation, bird watching, nature study, beach walking, or hiking and walking in an undeveloped area, where natural scenery and wild plants and animals add to the outdoor experience, are at least equal in importance to fishing and hunting. In the Dade County area in 1970, both residents and tourists accounted for more than 29 million user occasions when all these activities were lumped together. Fish and wildlife oriented activities can continue to provide a meaningful and economically important base for the Dade County area if the current misuse of land and water is corrected and the present undisturbed acreage is retained.
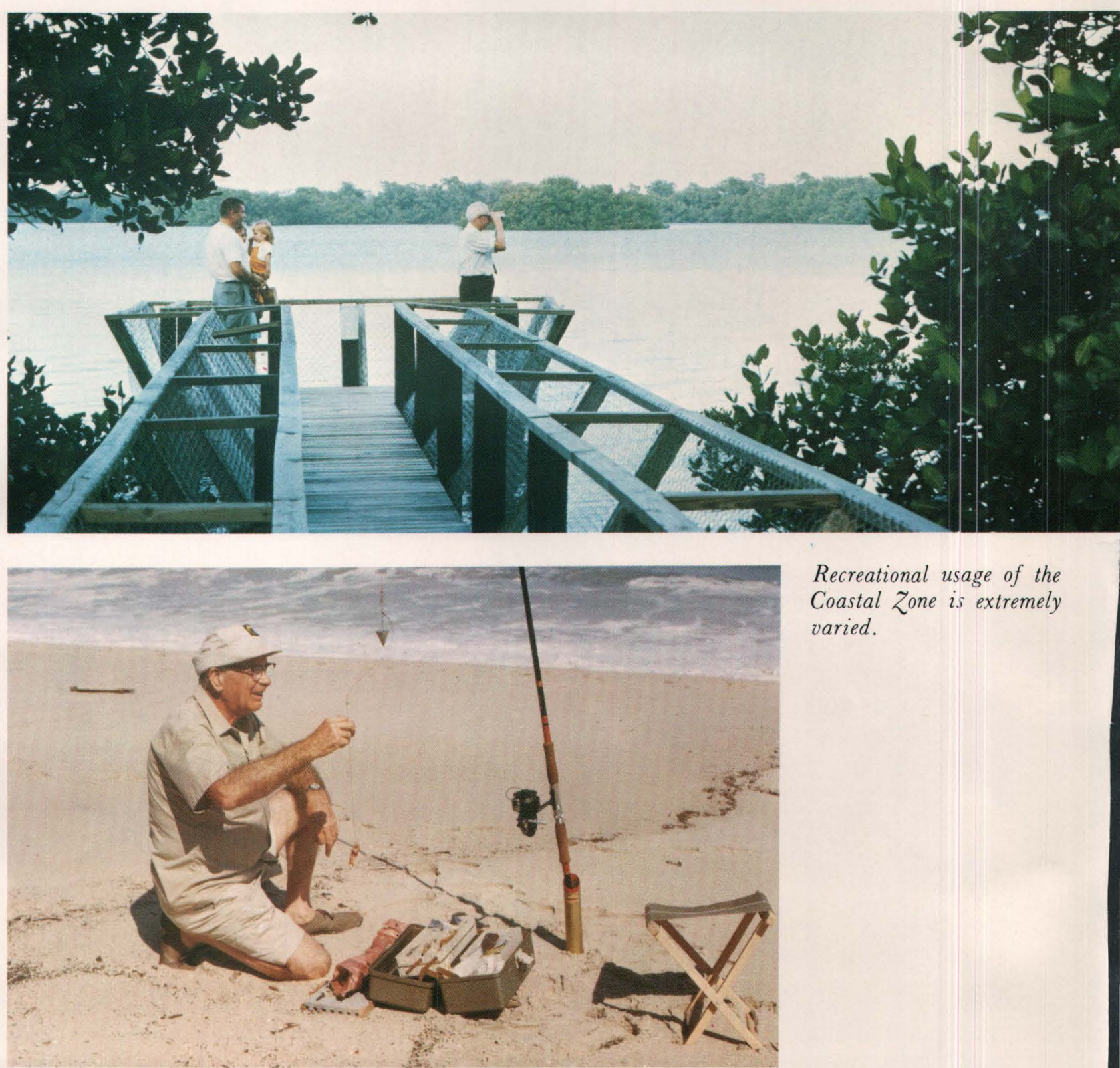

Recreational usage of the Coastal Zone is extremely varied. 


\section{Exotic Animals and Plants}

In 1971 a total of $31,122,579$ animals were imported through Miami. This represented 30 percent of all wildlife imported into the United States that year. Included were 62,805 mammals-mostly primates; 29,299,397 live fish; 2,413 mollusks and crustaceans; 47,297 amphibians; and $1,249,232$ reptiles-varying in species from large snakes such as boa constrictors, pythons, and deadly cobras to small caymans and chameleons.

Such imports are increasing at a rapid rate. For example, in 1969 more than 640,000 wild birds, representing more than 800 species, were imported into the United States. About half of these came through the Customs Office in Miami. By 1971 the number of birds had increased to almost one million $(995,260)$ with 51 percent $(511,435)$ coming through Miami.

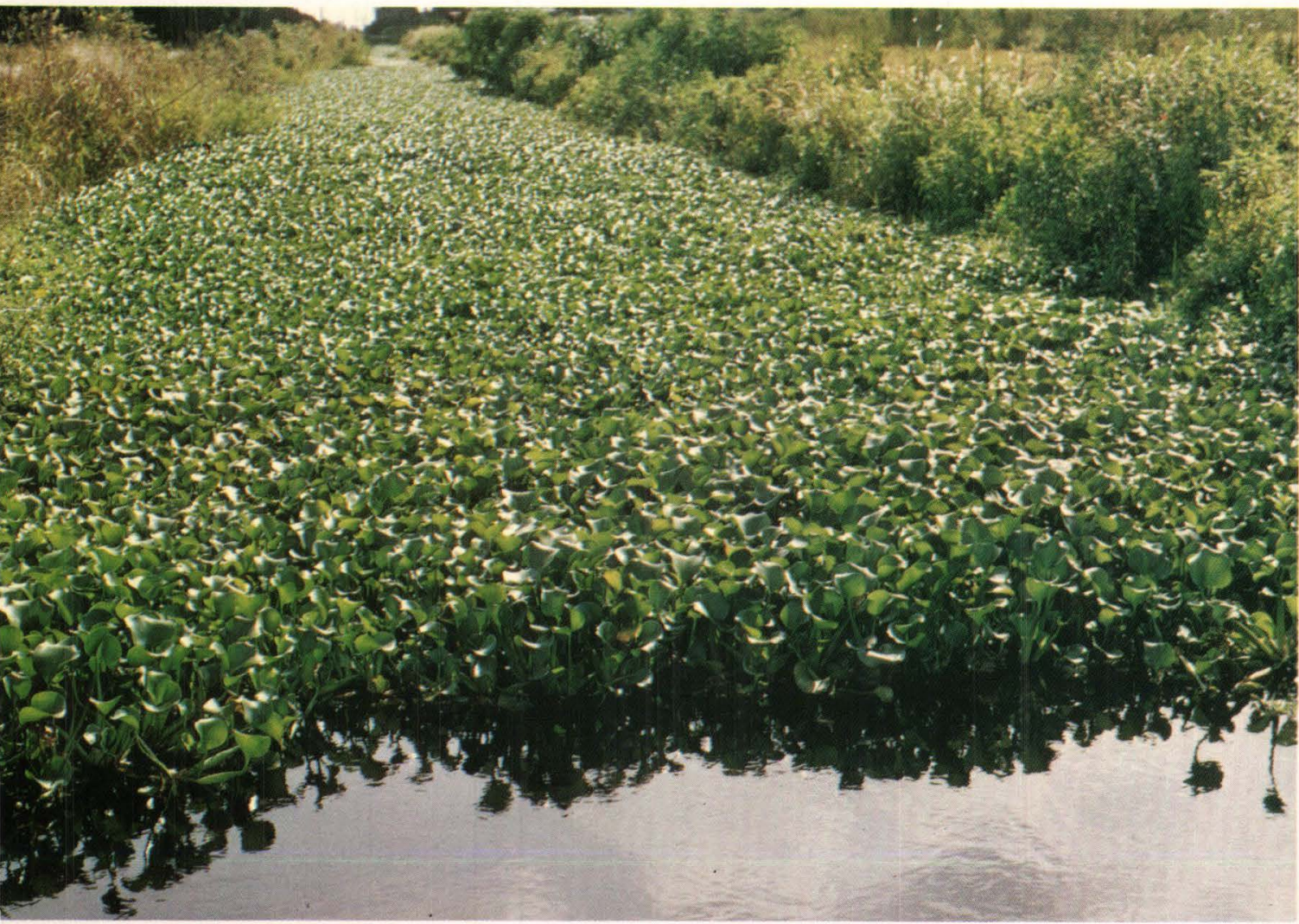

WATER HYACINTH

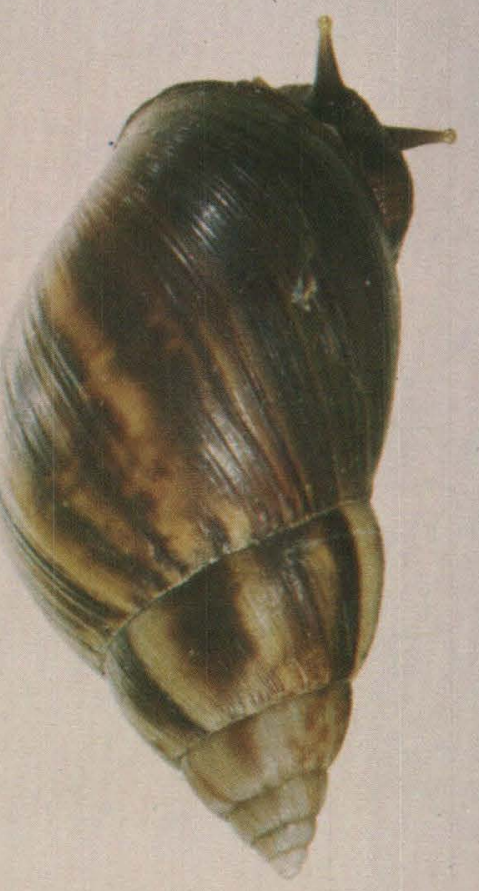

GIANT SNAIL

Exotics introduced to the area, either intentionally or by accident, frequently spread rapidly and compete dangerously with native species.

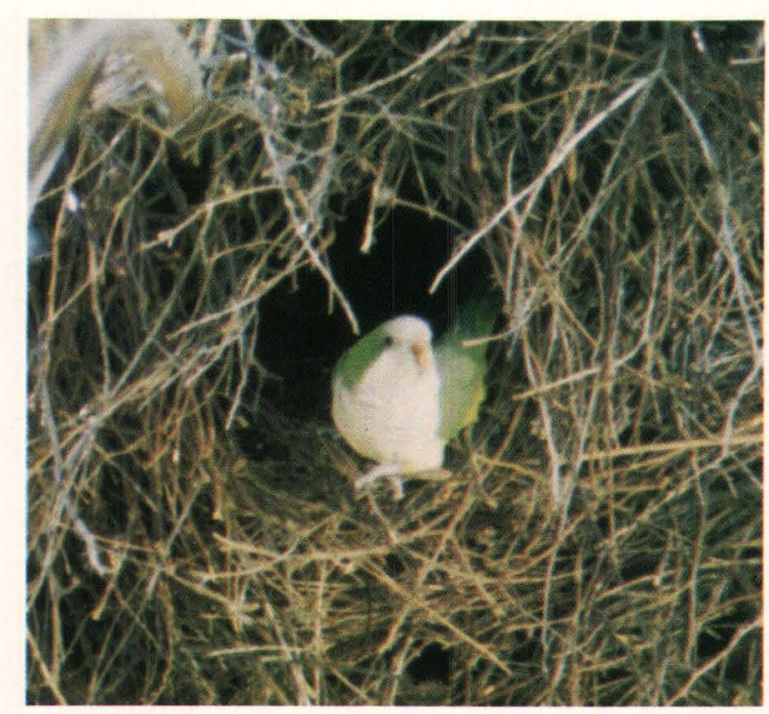

MONK PARAKEET
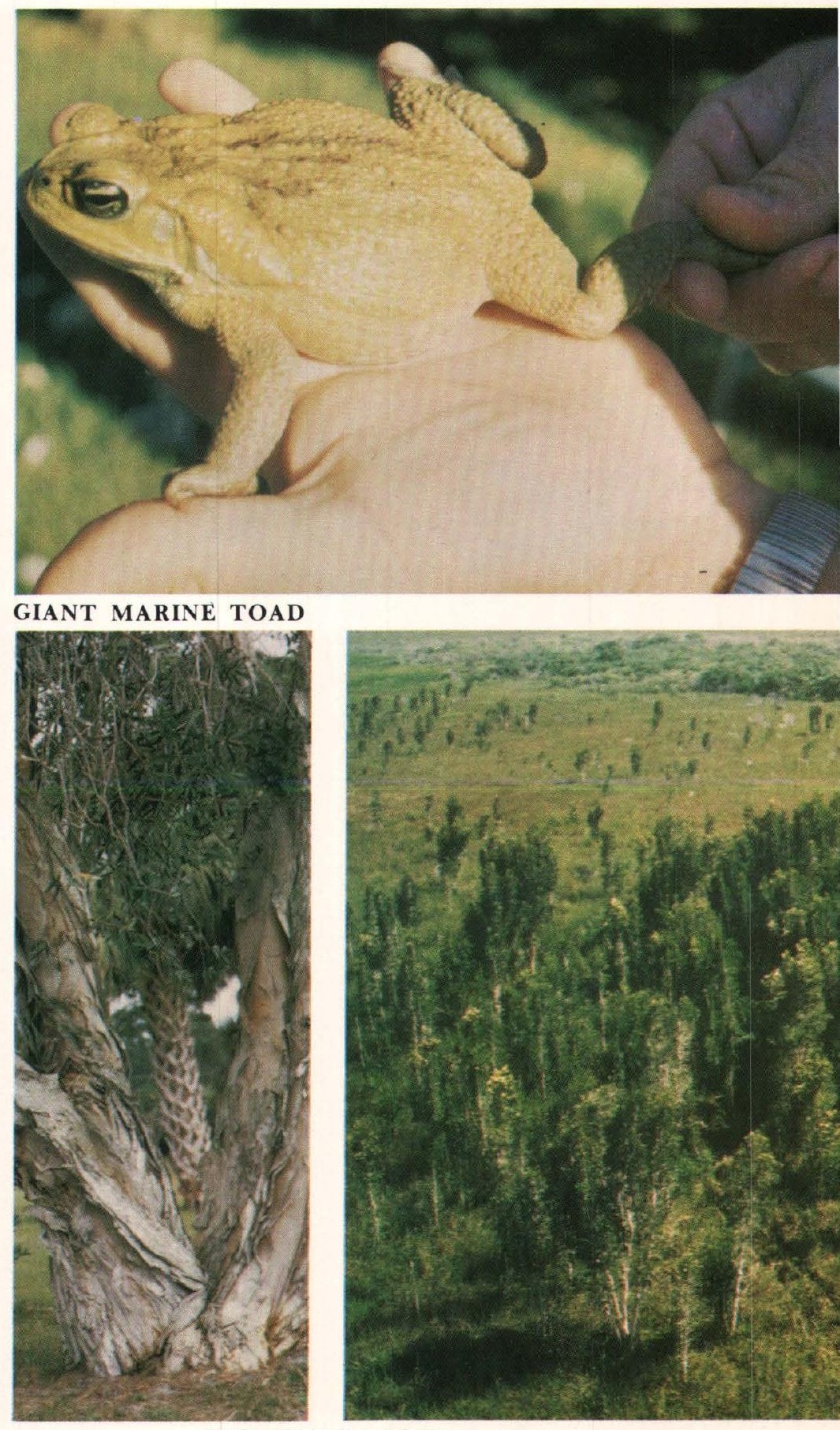

MELALEUCA TREE

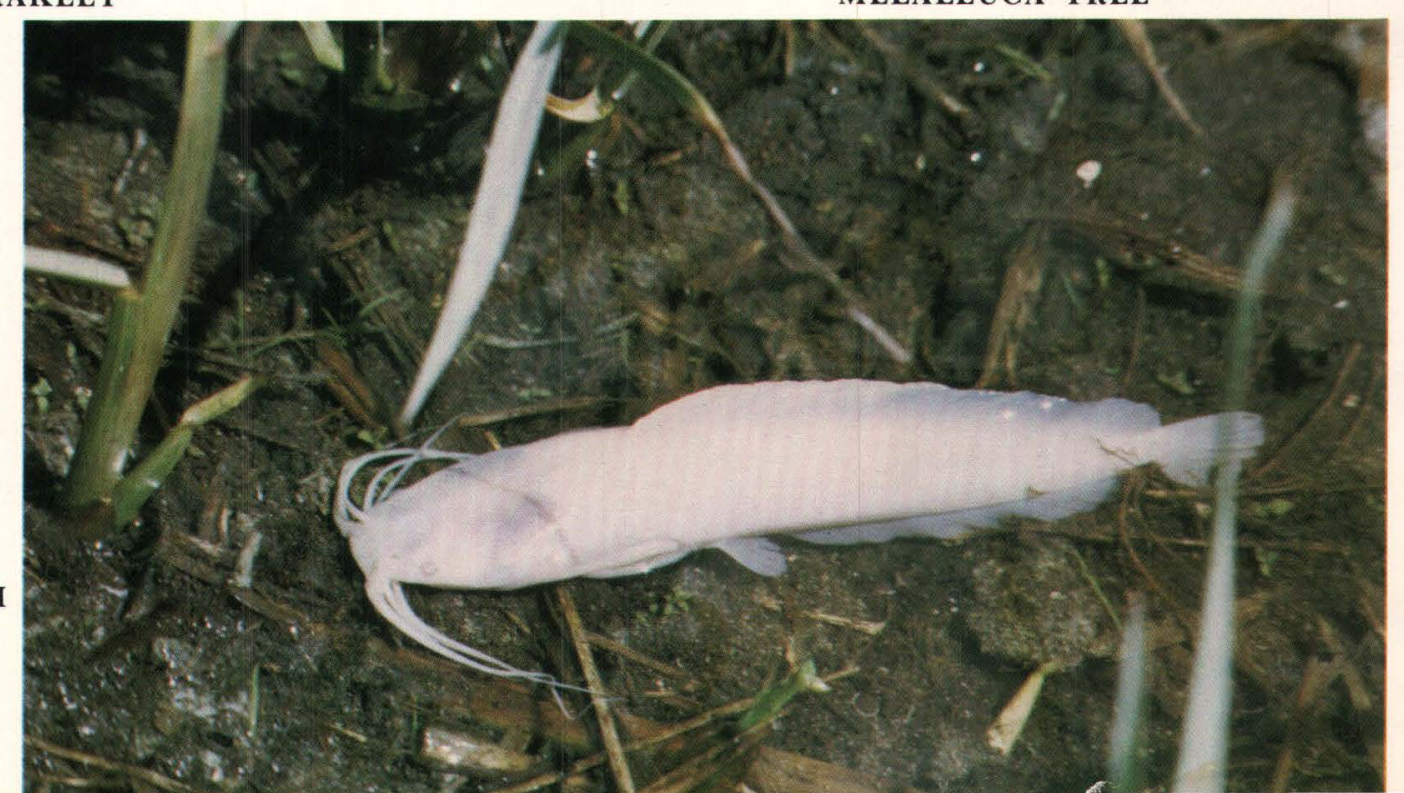




\section{FISH AND WILDLIFE}

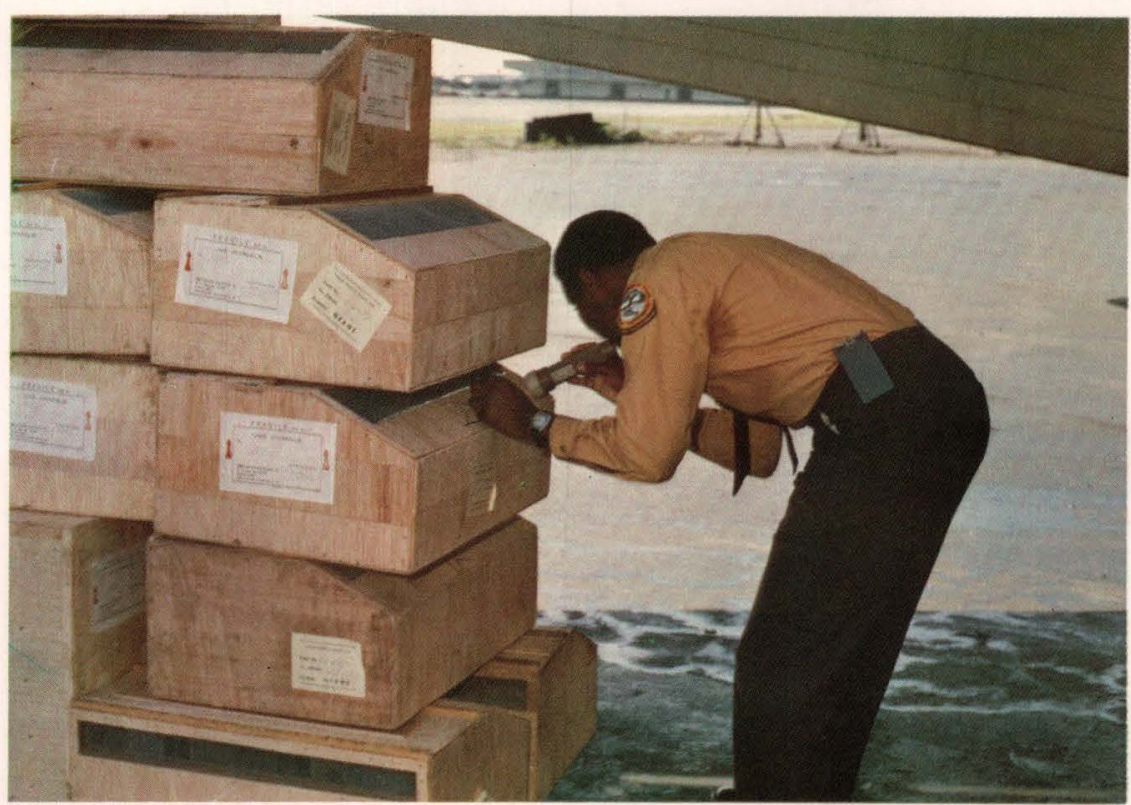

Because of the semi-tropical climate of southern Florida and because most of the imported plants and animals come from the tropical or semi-tropical countries of South America and Africa, these exotics flourish here, and the chances of establishment of accidentally released animals and plants is greater. However, many are capable of surviving in more temperate climates. A good example is the monk parakeet. Now well established in Miami as several nesting flocks, individuals or small flocks are also surviving in other States such as New York, New Jersey, Wisconsin, Virginia, and Georgia.

Millions of dollars are spent each year to rid waterways of exotic plants such as water hyacinth. The melaleuca tree, although serving as a fine wind break in certain areas, is already competing dangerously with native species in the Everglades. The most significant group, however, is the fish species that have become so well established in some bodies of water in Florida. Since Florida is potentially in the most vulnerable position for damage from these unwanted exotics, the Florida Game and Fresh Water Fish Commission has established a list of species of fish which may not be transported into or possessed in the State without a permit from the Commission.

The Florida Game and Fresh Water Fish Commission is actively pursuing a new monitoring program to restrict the importation of exotics that may prove harmful to the environment. They are especially concerned about those species that may become agricultural pests, vectors of human or domestic and wild animal diseases, or overly competitive with native species for space, food, or nesting habitat.

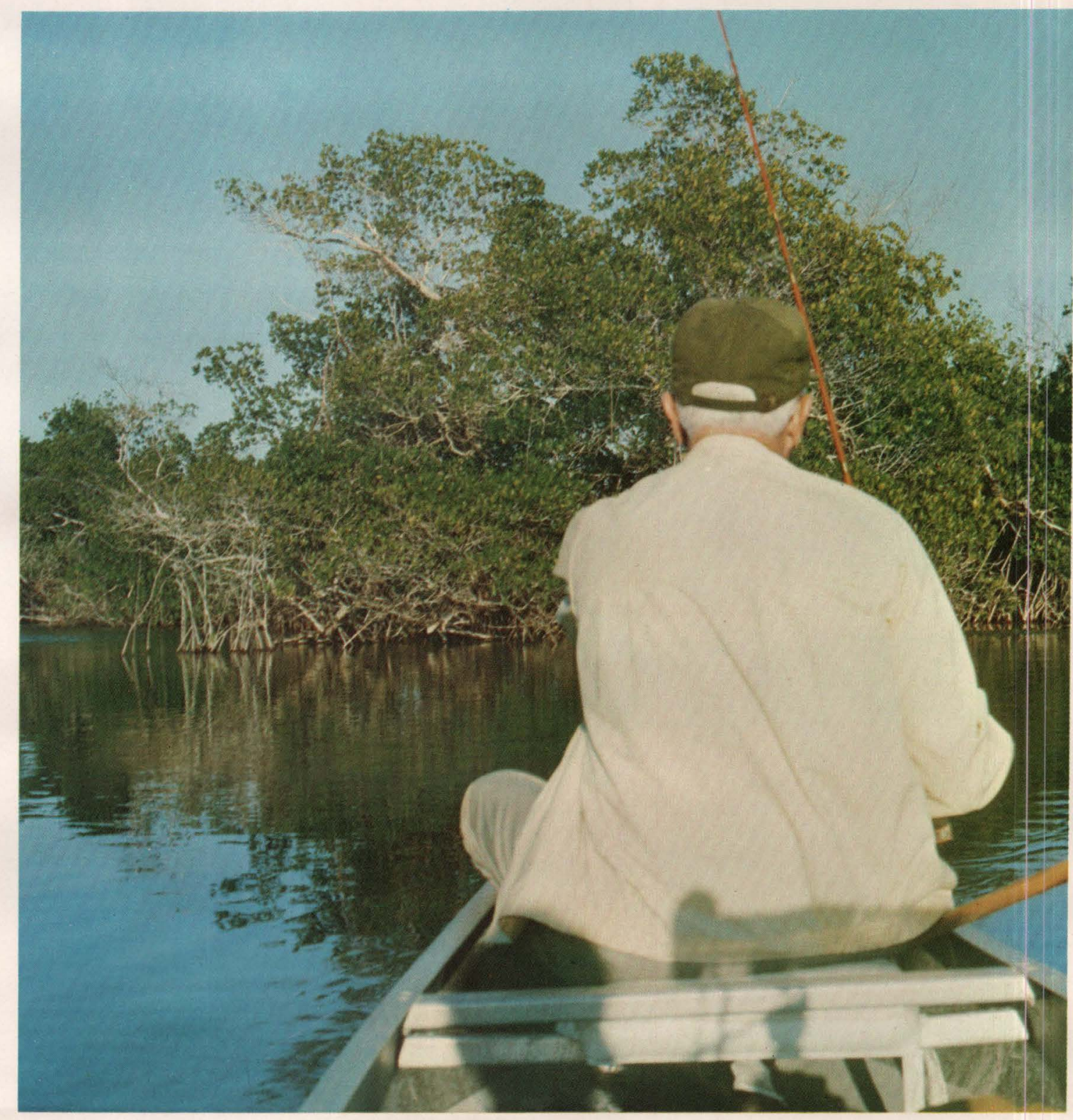




\section{MICCOSUKEE INDIANS}

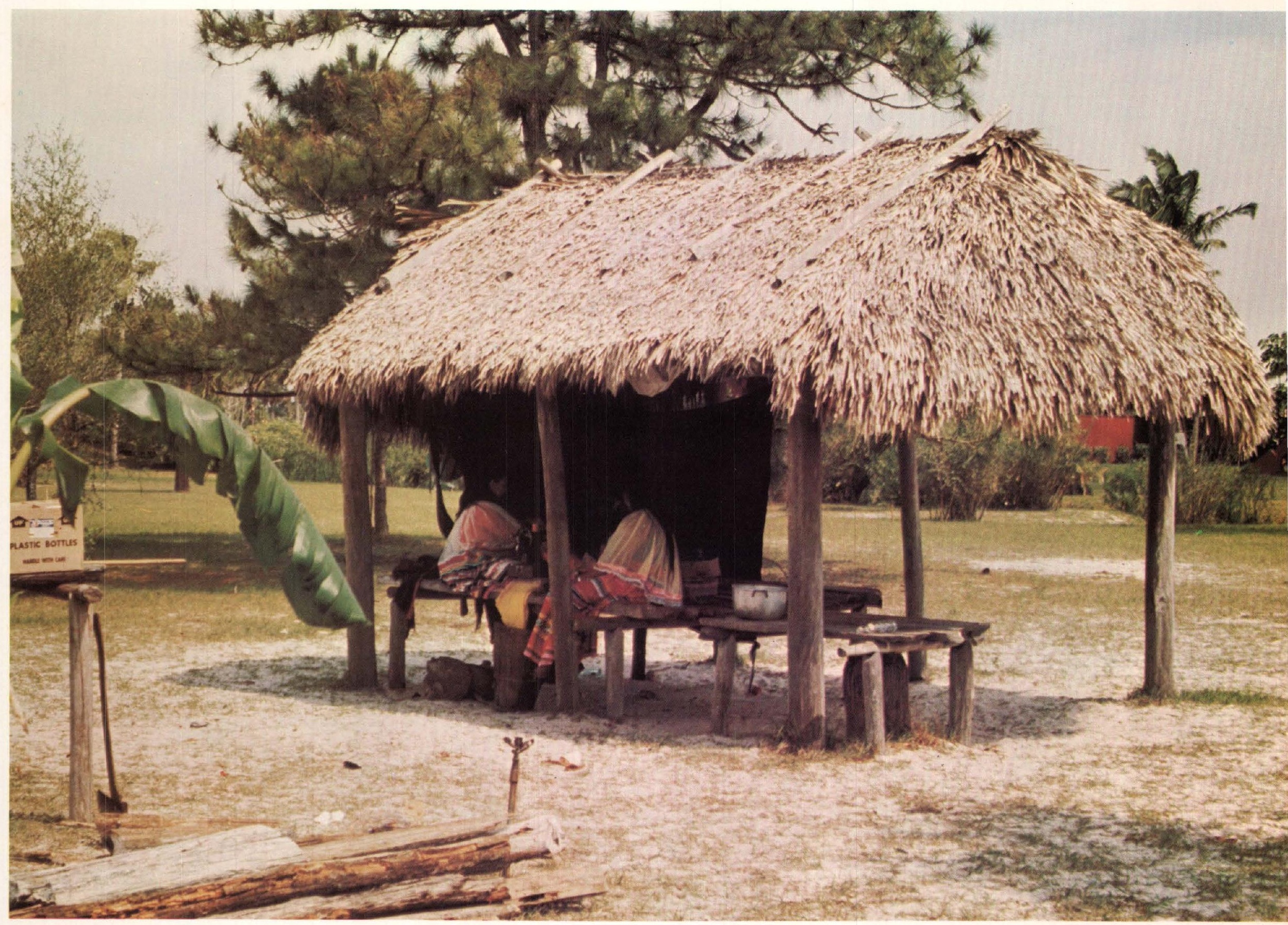

In the early 1500's the Creek Nation was composed of two major language groups, Muskogee and Hitchiti. The Hitchiti group was given the name "Mikasuki" which has evolved into "Miccosukee". The Miccosukee Tribe occupied parts of the Carolinas and Georgia until white settlers began arriving in the late 1500 's when the Miccosukee began moving inland and southward, settling in north Florida around Tallahassee.

Pressures of colonization in the north, as well as armed conflicts, forced the Miccosukee (and also the Seminoles living in northeast Florida), to move farther and farther south and eventually into the Everglades where they were able to live in relative safety, since battles fought in the swamp usually resulted in Indian victories.

The Indian Removal Act, which resulted in mass removal of Indians to land west of the Mississippi, caused the Miccosukee to move still farther south to escape forced transfer to Oklahoma. Again, hostilities broke out as colonists and the Army burned homes and crops in an effort to discourage the Indians and to acquire the much coveted land. Resistance was bitter and resulted in the Seminole Wars. Some tribes were defeated and forced to resettle on reservations in Oklahoma. The remaining Miccosukee and Seminoles fled into the depths of the Everglades, living on hammocks and subsisting by fishing and hunting. The Miccosukee successfully adapted to and were self-sufficient in their new environment.

With the establishment of Everglades National Park, the Florida Fresh Water Fish and Game Commission, and various private development projects, more and more land was taken from the Miccosukee by State and Federal legislation. When the boundaries of the Park were expanded northward to their present position, encompassing most of the Indian hammocks, the Miccosukee were forced to move. They faced the options of moving to a newly granted State reservation 50 miles to the north (90 percent under water and without access roads or development of any kind), or living along a $5 \frac{1}{2}$ mile strip of park land in the vicinity of their old hammocks on a use permit basis. Choosing the latter, 430 of them live today (1972) in small settlements on a narrow strip along the north boundary of the park, and 175 live along the Tamiami Trail between Miami and Naples. 


\section{MICCOSUKEE INDIANS}

Only a few Miccosukee families live directly within the south Dade County area. However, the west boundary of the area is near the strip of land where the majority of the Miccosukee Indians live. The problems (human, environmental, natural resources, etc.) within this area have a direct influence on the present and future life of these people.

The Miccosukee Indians are concerned with two major complexly interrelated types of problems. These are the internal or domestic problems, such as education, income, and employment, and external problems related to population growth, industrialization, water availability, water pollution, and land use within the entire region.

\section{Internal Problems}

The primary internal problems facing the Miccosukee Indians are unstable and inadequate economic and labor bases, and poor living and educational conditions. In the move to land along the Tamiami Trail, the Miccosukee Indian people were compelled to surrender their self-sufficiency and to change their economic base to the dollar economy. Recognizing the necessity of mastering this change to survive, the Tribe elected to pursue institutionalized education (absent prior to 1962), vocational instruction and training, and economic development. In order to achieve self-sufficiency again, the Tribe is working closely with County, State, and Federal agencies to bring about improvements in education and development.

Being limited, after relocation, by land-use regulations and the types of activities which they were able to pursue, the Miccosukee Indian people have sought assistance in attaining competence in individual trades and crafts, and in the operation of small tourist-oriented business. They have sought to plan a mixture of these which will provide the Tribe with a sound economic base.

According to the 1973 Community Action Program report, 95 percent of the population is below Federal poverty lines, and the unemployment rate is 35 percent. Approximately 50 percent of eligible students attend elementary school, the low figure being due to the newness of the program as well as problems of language and transportation. Only 7 percent of eligible students attend high school, mainly because of a lack of facilities.

Currently the Tribe operates a restaurant, a gas station, and a grocery store and has plans for additional facilities. Tribal members are employed in the education programs for teaching, cooking, and maintenance activities, in administration and planning, and in construction related to tribal enterprises. Privately, the Miccosukees are engaged in the construction of "chickees" (thatched roof structures with no outside walls), wrestling alligators, managing gift shops, making and selling handcrafted objects, selling frog legs, driving air boats,and selling bait and tackle. Occasionally, they seek employment in Miami, primarily in construction work.
Income for the Tribe is derived from tribal enterprises and from a few small pieces of land for which the Tribe is paid rent. The income is used to support education and development programs, such as a community building currently under construction, and for financial assistance to tribal members.

\section{External Problems}

Some of the external problems in southern Dade County are of immediate concern to the Miccosukee Indians as these problems are now affecting or will affect the Miccosukee's way of life. One of the most pressing of these problems is that of increases in the non-Indian population nearby. Population of the census tract that includes the Miccosukee area increased 596 percent in the 1960's. These increases, plus a growing number of tourists, have created problems in the allocation and use of the area's natural resources.

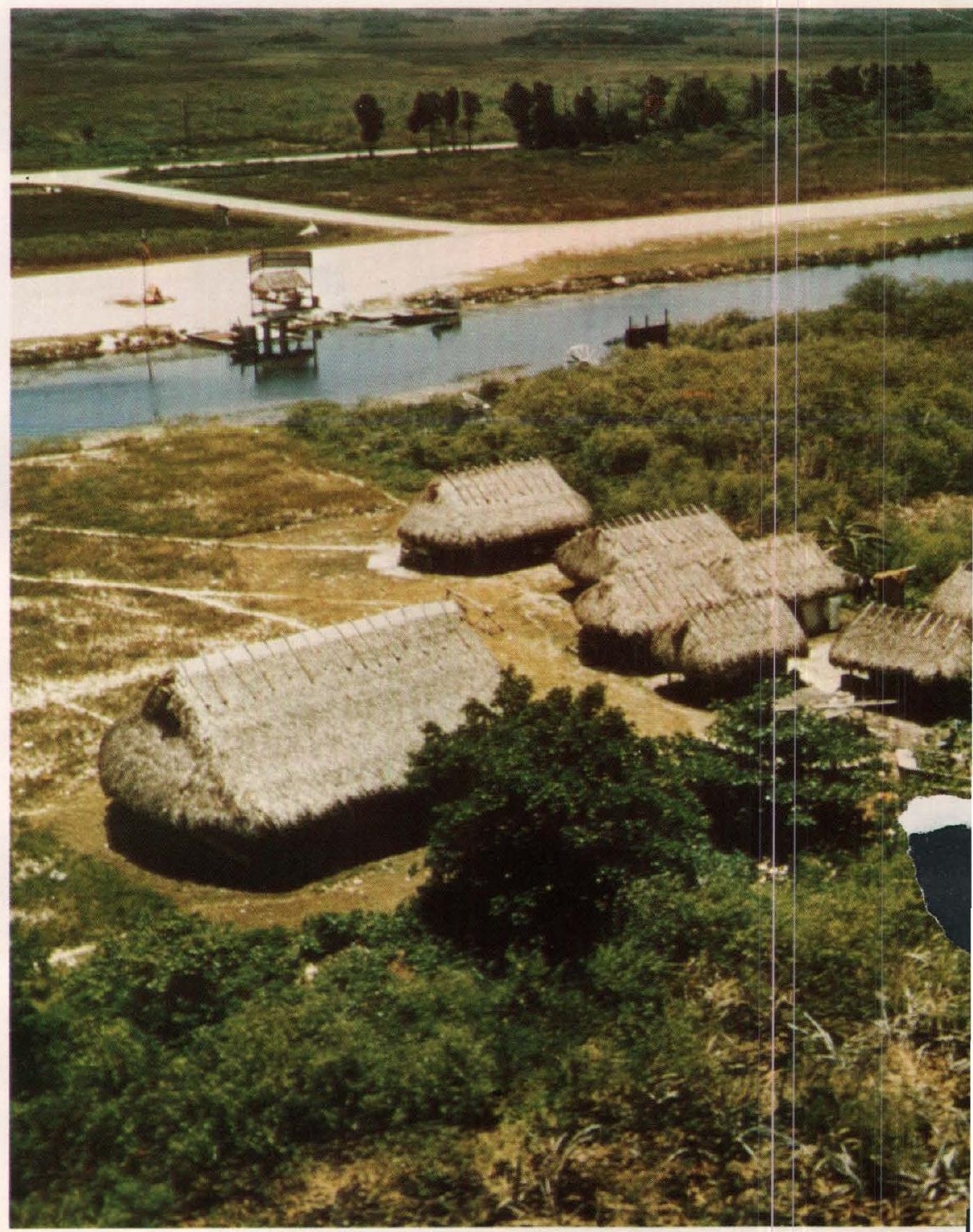

In addition to population increases or urbanization, agriculture, highway construction and industrialization are consuming more and more land each year. All of these developments involve environmental changes, either in terms of land use or of the pervasive effects of pollution, that will significantly affect the way of life of the Miccosukees. They live in a fragile ecosystem that will not bear much encroachment. 
Problems of water quantity and quality are of great concern to the Miccosukee Indians as they depend on the Everglades and its habitat as a source of food and income. The inability to make a living by hunting and fishing is due to over-hunting by non-Indians, destruction brought about by unmanaged recreation, and to alteration of waterflow patterns in the Everglades. With the ever-increasing demands of the urban areas, agriculture and industry on the water supply of the area, the Miccosukee are faced with the detrimental effects not only of a general lowering of the water level but also of pollutants in their water supply, which contributes to a further reduction of game.

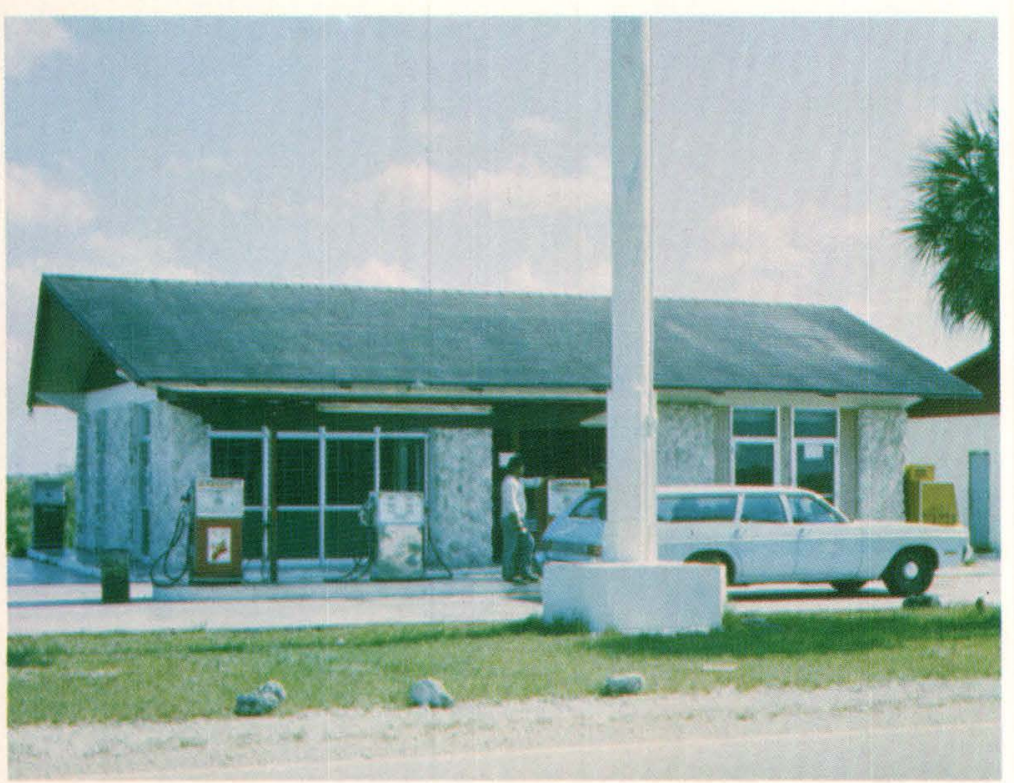

Decisions affecting water flow or use on either coast to the north have a pronounced effect on the Miccosukee Indian community.

The effects of social and economic growth in the area can be recognized and controlled through coordinated development taking cognizance of the ecology of the Everglades area. This will involve cooperative planning efforts from the Miccosukee Tribe, Everglades National Park, the South Florida Regional Planning Council, individual home owners along the Tamiami Trail, and The Seminole Tribe of Florida working in conjunction with development agencies, commissions, and research groups.

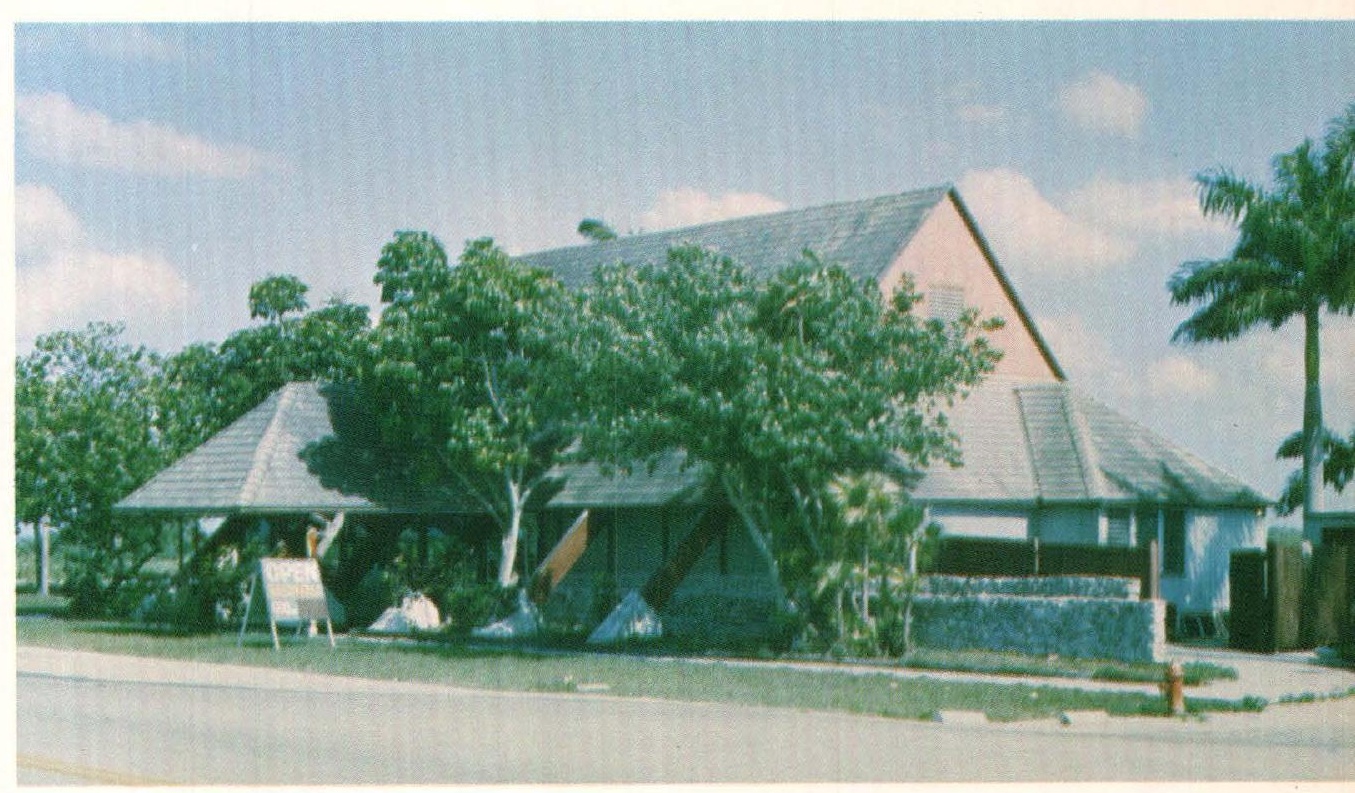




\section{CONCLUSION}

South Dade County is an area of intense environmental pressures, both internal and external. Here urbanization is replacing farming and pressing against the east boundary of Everglades National Park. Development has changed some of the estuarine areas from a mangrove swamp habitat to bulkheaded developments. The problems of water supply and waste disposal-particularly sewage-are inextricably linked to the regional water system that extends as far north as Lake Okeechobee. The environment of the south Dade area is totally water dependent.

Because south Florida is so flat, many of the normal engineering approaches cannot be used to solve water and related environmental problems. Water cannot be stored in reservoirs and moved readily. Water management, rather, has had to accommodate to the flatness of the area and its proximity to sea level. Moreover, the manipulation of the water system for the benefit of people could not be inimical to the balanced ecology of plants and animals. Much detailed data had to be collected before management schemes could be formulated and alternatives evaluated. The available data upon which the water management plans for south Florida are based have been collected over a period of many years. Natural resources data have been analyzed and correlated with other social, economic, and demographic data in development of these water management plans. Yet further stresses will require continual improvement in the water management plans. This in turn will require even more detailed resources data.

Planning in the south Dade area is predicated on available water. Hence this document has stressed the water management which has provided well for the past growth and aims at accommodating future planned growth. So complex and intertwined are the resources and the needs that detailed information is essential to sound planning. In this study, we have presented generalized data embracing the climate, topography, hydrology, pedology, biology, and geology of the area. Detailed data, which have been generalized for this study, are available to the planner.

Development of both regional plans and the management alternatives to implement these plans will become increasingly complex as environmental stresses increase with further development. Moreover, environmental problems develop faster than the information needed to address them is normally collected. Modelling of the environment, including social, economic and political constraints, will likely offer a means of evaluating the complex interactions of alternative plans. This modelling will require continual input and refinement of data. Although a veritable wealth of data on the natural resources of the area now exists, the sophisticated approaches of future planning, especially through modelling, will likely require both new types of data and greater detail of existing data.

Many organizations, both governmental and private, are concerned about the environment of south Florida. The Department of the Interior shares this concern. Land-use planning, based on realistic objectives and sound resource and environmental data, can accommodate growth commensurate with environmental protection. 


\section{PHYSICAL SETTING}

1. Adapted from The Natural Features of Southern Florida-Especially the Vegetation, and the Everglades, J. H. Davis, Jr.: Florida Geological Survey Bulletin 25, 1943

2. Relief Map, Metropolitan Dade County Planning Department. (Topographic contours are based on topographic quadrangles of the U.S. Geological Survey.), 1971

3. Generalized Soils Types (map), Metropolitan Dade County Planning Department. (Soils data are based on the Soil Survey, Dade County, Florida; Soil Conservation Service, U.S. Department of Agriculture, Series 1947, No. 4, 1971)

4. Bay segment of this cross section after Sediments of Biscayne Bay-Distribution and Depositional History, H. R. Wanless, Jr.: Institute of Marine and Atmospheric Sciences, University of Miami Technical Report 69-2, 1969

\section{URBANIZATION}

1. Census of Population, U.S. Department of Commerce, Bureau of Census, 1970

2. Metropolitan Miami-A Demographic Overview, W. W. Jenna: University of Miami Press, 1972

3. Transportation Master Plan, Miami Urban Area Transportation Study, Metropolitan Dade County, Miami, Florida, 1969

4. A Land-Use Classification System for Use with Remote-Sensor Data, J. R. Anderson, E. E. Hardy, and J. T. Roach: U.S. Geological Survey Circular 671, 1972

5. Based on information from the Metropolitan Dade County Planning Department, 1973

\section{NATURAL HAZARDS}

1. Land Fill Requirements in Environment Comprehensive Development Master Plan for Dade County, Metropolitan Dade County Planning Department, 1973

2. Hurricane Shelter Program. Miami Federal Executive Board, 1973

3. Metropolitan Dade County Planning Department, 1973

\section{MINERAL RESOURCES}

1. Standard Method to Test for Abrasion Resistance of Large Size Coarse Aggregates by Use of the Los Angeles Machine, Designation C 535-69, American Society for Testing Materials, 1969

2. Standard Method to Test for Abrasion Resistance of Small Size Coarse Aggregates by Use of the Los Angeles Abrasion Machine. Designation C 131-69, American Society for Testing Materials, 1969

\section{MANAGING THE WATER SYSTEM}

Biscayne aquifer of Dade and Broward Counties, Florida, M. C. Schroeder, H. Klein, and N. D. Hoy: Florida Geological Survey Report of Investigation 17, 1958

2. Water Resources of Southeastern Florida, with special reference to the geology and ground water of the Miami area, G. G. Parker, G. E. Ferguson, S. K. Love, and others: U.S. Geological Survey WaterSupply Paper 1255, 1955

3. Hydrologic conditions during 1971 in Dade County, Florida, J. E. Hull and E. T. Wimberly: U.S. Geological Survey Open-file Report 72024, 1972

4. Hydrologic effects of water control and management of Southeastern Florida, S. D. Leach, H. Klein, and E. R. Hampton: Florida Department of Natural Resources, Bureau of Geology, Report of Investigation 60,1972

5. Effect of pulse recharge on the zone of diffusion in the Biscayne aquifer, F. A. Kohout and H. Klein: Bulletin of the International Association of Scientific Hydrology, 1967

6. Availability of ground water for the Navy well field near Florida City, Dade County, Florida, F. W. Meyer: U.S. Geological Survey Open-file Report, in preparation

7. Water quality management plan for Metropolitan Dade County, Florida, preliminary draft, Greeley and Hansen, Connell Associates, Consulting Engineers, March 1973

8. Hydrologic effects of Area B flood control plan on urbanization of Dade County, Florida, F. A. Kohout and J. H. Hartwell: Florida Geological Survey Report of Investigation 47, 1967

9. Preliminary evaluation of the hydrologic effects of implementing water and sewerage plans, Dade County, Florida, F. W. Meyer: U.S. Geological Survey Open-file Report 71003, 1971

10. Effects of abatement of domestic sewage pollution on the benthos, volumes of zooplankton, and the fouling organisms of Biscayne Bay, Florida, J. K. McNulty: Studies in Tropical Oceanography No. 9, Institute of Marine and Atmospheric Sciences, University of Miami, 1970

11. An environmental land planning study, south Dade County, Florida, A. R. Veri: Division of Applied Ecology, Center for Urban Studies, University of Miami, 1971

12. Water and the south Florida environment, H. Klein, J. T. Armbruster, B. F. McPherson, and H. J. Freiberger: U.S. Department of the Interior Special Publication, 1973

13. Saline ground water in southern Florida, C. B. Sherwood and H. Klein: Ground Water, Volume 1, No. 2, April 1963

14. Water resources for central and southern Florida, Corps of Engineers Survey Review Rept. on Central and Southern Florida Project, 1968 


\section{ENVIRONMENTAL QUALITY}

1. Adapted from The Natural Features of Southern Florida-Especially the Vegetation, and the Everglades, J. H. Davis, Jr.: Florida Geological Survey Bulletin 25, 1943

2. South Florida-A Case Study in Carrying Capacity, A. R. Marshall: An address to the American Association for the Advancement of Science, Washington, D.C., 1972

3. A Cursory View of Florida's Waste Treatment Plants and Future Needs, Florida Department of Air and Water Pollution Control, Tallahassee, Florida, 1970

4. Environmental Assessment of the Interim Water Quality Management Plan, Metropolitan Dade County Water and Sewer Authority, Miami, Florida, 1972

5. Engineering and Economic Report on Solid Waste Collection and Disposal for Metropolitan Dade County, Greenleaf/Telesca Planners, Engineers, and Architects, Miami, Florida, 1972

6. Summary Report, Solid Waste Collection and Disposad, Greenleaf/Telesca Planners, Engineers, and Architects, Miami, Florida, 1972

7. Data on Florida Bay from J. G. Palacas, USGS, unpublished, 1973

8. Distribution of Mercury in Unconsolidated Sediments from Southern Lake Michigan, E. J. Kennedy, R. R. Ruch, and F. Shimp: Illinois Geological Survey Environmental Geological Note 43, 1971

9. Distribution of Mercury in Surficial Sediments in San Francisco Bay Estuary, D. S. McCulloch, T. J. Conomos, D. H. Peterson, and K. Leong: U.S. Geological Survey Open-file Report, 1971

10. Some Aspects of the Effects of the Quantity and Quality of Water on Biological Communities in Everglades National Park, M. C. Kolipinski and A. L. Higer: U.S. Geological Survey Open-file Report, Tallahassee, Florida, 1969
11. Dade County Agriculture, Metropolitan Dade County, Miami Florida, 1971

12. Environmental Problems in South Florida, The Environmental Studies Group for the National Academy of Engineering, Washington, D. C., 1969

13. Organochlorine Insecticide Residues in Everglades National Park and Loxahatchee Wildlife Refuge, Florida, M. C. Kolipinski, A. L. Higer, and M. L. Yates: Pesticides Monitoring Journal Volume 5, No. 3, 1971

14. Sampling Procedures and Problems in Determining Pesticide Residues in the Hydrologic Environment, H. R. Feltz and J. K. Culbertson: Pesticide Monitoring Journal, Volume 6, No. 3, 1972

15. Epidemiologic Studies of the Effects of Pesticides on the General Population, J. Davies: Report of the Secretaries Commission on Pesticides and their Relationship to Environmental Health, U. S. Department of Health, Education and Welfare, Washington, D. C., 1969

16. Temperature Studies, Lower Biscayne Bay, Florida, L. B. Tebo, R. L. Estes, and R. R. Lassiter: Federal Water Pollution Control Administration, Washington, D. C., 1968

17. The Beneficial Uses of Zones of High Transmissivities in the Florida Subsurface for Water Storage and Waste Disposal, R. O. Vernon: Florida Department of Natural Resources, Bureau of Geology, Information Circular No. 70, Tallahassee, Florida, 1970

18. Orientation, J. T. Cox: Orientation Paper for the Advisory Task Forces, Metropolitan Dade County Planning Department, Miami, Florida, 1973

\section{OUTDOOR RECREATION}

1. Regression Model Developed by Central and Southern Florida Flood Control District under contract issued as part of the South Florida Ecological Study. Original survey participation rate data were provided by the Florida Division of Recreation and Parks, 1972 